\title{
ÁCAROS ERIOPHYOIDEA (PROSTIGMATA) ASSOCIADOS A PALMEIRAS (ARECACEAE), COM ÊNFASE NO ÁCARO DO COQUEIRO, ACERIA GUERRERONIS KEIFER - ESPECTRO DE HOSPEDEIROS E ASPECTOS BIOGEOGRÁFICOS
}

\author{
Denise Navia Magalhães Ferreira
}

Tese apresentada à Escola Superior de Agricultura "Luiz de Queiroz", Universidade de São Paulo, para obtenção do título de Doutor em Ciências, Área de Concentração: Entomologia.

P I R A C I C A B A

Estado de São Paulo - Brasil

Fevereiro - 2004 


\title{
ÁCAROS ERIOPHYOIDEA (PROSTIGMATA) ASSOCIADOS A PALMEIRAS (ARECACEAE), COM ÊNFASE NO ÁCARO DO COQUEIRO, ACERIA GUERRERONIS KEIFER - ESPECTRO DE HOSPEDEIROS E ASPECTOS BIOGEOGRÁFICOS
}

\author{
Denise Navia Magalhães Ferreira
}

Orientador: Prof. Dr. GILBERTO JOSÉ DE MORAES

Tese apresentada à Escola Superior de Agricultura "Luiz de Queiroz", Universidade de São Paulo, para obtenção do título de Doutor em Ciências, Área de Concentração: Entomologia.

P I R A C I C A B A

Estado de São Paulo - Brasil

Fevereiro - 2004 


\section{Dados Internacionais de Catalogação na Publicação (CIP) DIVISÃO DE BIBLIOTECA E DOCUMENTAÇÃO - ESALQ/USP}

\section{Navia Magalhães Ferreira, Denise}

Ácaros Eriophyoidea (Prostigmata) associados a palmeiras (Arecaceae), com enfâse no ácaro do coqueiro, Aceria guerreronis Keifer - espectro de hospedeiros e aspectos biogeográficos / Denise Navia Magalhães Ferreira. - - Piracicaba, 2004.

$435 \mathrm{p}$.

Tese (doutorado) - Escola Superior de Agricultura Luiz de Queiroz, 2004.

Bibliografia.

1. Ácaro fitófago 2. Biogeografia 3. Coco 4. Controle biológico 5. Fitossanidade 6. Marcador genético 7. Morfometria 8. Palmeira I. Título

CDD 632.6542 
À Deus, Energia Criadora

\section{AGRADEÇO}


Aos meus pais Harold e Maria de Lourdes, Aos meus irmãos Alexis e Elyn, pelo amor, apoio incondicional e compreensão,

\section{DEDICO}


Ao meu namorado e amigo Carlos Boriam, pelo estímulo, companheirismo e compreensão,

\section{DEDICO}




\section{Aos Professores \\ Gilberto José de Moraes e Carlos Holger W. Flechtmann, pela orientação, apoio e exemplo de dedicação,}

\section{Agradeço especialmente}




\section{AGRADECIMENTOS}

À Embrapa Recursos Genéticos e Biotecnologia, pela oportunidade de realização do curso.

Ao Conselho Nacional de Desenvolvimento Científico e Tecnológico (CNPq) pela concessão da bolsa de doutorado no país.

À Coordenação de Aperfeiçoamento de Pessoal de Nível Superior (Capes) pela concessão da bolsa de doutorado sanduíche.

Este trabalho foi parcialmente financiado pela Fundação de Amparo à Pesquisa do Estado de São Paulo (FAPESP) no âmbito do Programa BIOTA/FAPESP - O Instituto Virtual da Biodiversidade (www.biotasp.org.br).

Aos pesquisadores colaboradores, Dra. Maria Navajas, Centre de Biologie et Gestions des Populations (CBGP), Montferrier-sur-Lez, França; Prof. Dr. Carlos H. W. Flechtmann, pesquisador CNPq, ESALQ, USP, Piracicaba, São Paulo, Brasil e Dra. Ranyse Barbosa Querino da Silva, INPA, Manaus, Amazonas, Brasil, pela transmissão de conhecimentos e experiências fundamentais para a execução do projeto de pesquisa e para meu crescimento profissional.

A todos os professores do Departamento de Entomologia, Fitopatologia e Zoologia Agrícola, ESALQ, USP, pelos ensinamentos transmitidos que muito colaboraram para minha formação profissional.

A todos os funcionários do Setor de Zoologia Agrícola e do Setor de Entomologia, ESALQ, USP, pela colaboração no decorrer do curso.

À Maria Regina Vilarinho de Oliveira, Embrapa Recursos Genéticos e Biotecnologia, pelo apoio e confiança desde o início da minha formação profissional. 
À Sandrine Cros-Arteil, pelo treinamento nas técnicas moleculares e acompanhamento nas atividades desenvolvidas; e a todos os colegas do CBGP, Montferrier-sur-Lez, França, especialmente a Alain, Claire, Isabella e Natalie pelo companheirismo e auxílio durante minha estadia no CBGP.

A J.M.S. Ferreira e R.P.C. Araújo, Embrapa Tabuleiros Costeiros, Aracaju, Sergipe, Brasil; L.S. Faria e E.F. Caetano, DFA-SE, Aracaju, Sergipe, Brasil; R. Konno, ESALQ, USP, Piracicaba, São Paulo, Brasil; J.A. Alencar e D.C. Alves, Embrapa SemiÁrido, Petrolina, Recife, Pernambuco, Brasil; M.G.C. Gondim Jr., UFRPe, Recife, Pernambuco, Brasil; M.M.Chagas, Natal, Rio Grande do Norte; C. Conte, DFA-RJ, Campos, Rio de Janeiro, Brasil; A.I. Ciociola Jr., Epamig, Janaúba, Minas Gerais, Brasil; L. Prezotti, Governador Valadares, Minas Gerais, Brasil; A.L. Jordão, IEPA, Macapá, Amapá, Brasil; A.M. Tavares, Embrapa Amazonas, Manaus, Amazonas, Brasil; M.A. L. Bittencourt, UESC, Ilhéus, Bahia, Brasil; E.S. Silva, São Félix, Bahia, Brasil; J.E. Pitta, DFA-AL, Maceió, Alagoas, Brasil; F.J. Murga, Guerrero, México; E.L.M. Molina, CIAT, Palmira, Colombia; M. Quirós \& D. Contreras, Univ. Zulia, Maracaibo, Venezuela; R.I. Cabrera, Inst. Inv. Fruticultura Tropical, MINAGRI, Havana, Cuba; H. Aguilar, Universidad de Costa Rica, San José, Costa Rica; T. M. Perring e T. Ansaloni, UC, San Diego, California, EUA; I. Zannou e R. Hanna, IITA, Cotonou, Benin; Z. Seguni, ARI Mikocheni, Tanzânia; N. S. Aratchige, CRI, Lunuwila, Sri Lanka; A. M. Ranjith, Kerala Agricultural Univ.,Vellanikara; P. S. P. V. Vidyasagar, CPCRI, Kasaragod e C. Mohan, CPCRI, Kayankulam, Kerala, India pelo envio de amostras, essenciais para o desenvolvimento do projeto de pesquisa.

A Luiz Antonio Ferraz Mattes, Instituto Agronômico de Campinas, Campinas, SP, pela autorização e acompanhamento das coletas na Coleção de Palmeiras da Fazenda Santa Elisa.

A Maria Magdalena Vázquez e a Claudia Chargoy, Quintana Roo, México; Alain Migeon, CBGP, Montferrier-sur-Lez, França; C. Conte, DFA, RJ; Ranyse B. Q. da silva, INPA e Adauto M. tavares, Embrapa Amazônia Ocidental, Manaus, AM, Brasil; M. F. Moreira, L. V. F. da Silva e G. P. Arruda Filho, ESALQ, USP, Piracicaba, SP; M.G.C. Gondim Jr., UFRPe, Recife, PE; J. C. Rodrigues, Univ. Florida, EUA e H. 
Aguilar, Univ. Costa Rica, San José, Costa Rica, pelo apoio logístico, auxílio e amizade durante as coletas de material vegetal.

A M. C. Alves, CIAGRI, USP e ao colega Raf de Vis, pelo suporte estatístico e em informática e pela disposição contínua em ajudar.

A M. F. Moreira, J.V.C.Guedes e Tatiane Maria, pelo auxílio nas fotografias.

A todos os colegas do Setor de Zoologia Agrícola e de Entomologia e de toda ESALQ, USP, pela amizade e por todos os momentos compartilhados, que serão para sempre lembrados com muitas saudades (ressalvo-me a não citar nomes pelo carinho que tenho a todos).

Ao meu colega e amigo Edmilson Santos Silva, que muito me ajudou e estimulou em diversas etapas do trabalho, especialmente na finalização.

À bibliotecária Eliana Maria Garcia Sabino e Silvia Zlinski, pelo auxílio na organização das referências bibliográficas e aos demais funcionárioas da Biblioteca Central , sempre disponíveis em ajudar. 


\section{SUMÁRIO}

Página

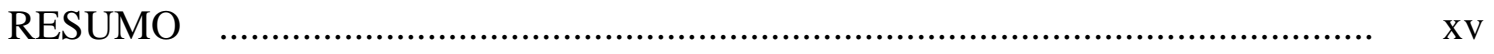

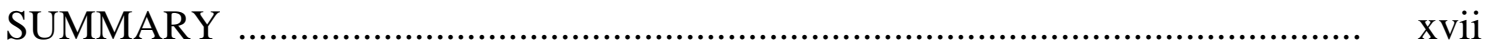

1 INTRODUÇÃ

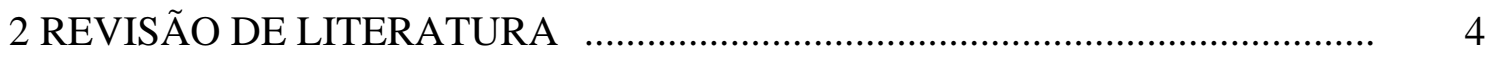

2.1 As palmeiras - diversidade, habitat e importância sócio-econômica ............... 4

2.2 Origem e disseminação do coqueiro, Cocos nucifera L. ................................ 5

2.3 Produção, utilização e importância sócio-econômica do coqueiro .................... 7

2.4 Eriophyoidea - aspectos gerais e importância econômica $\quad$............................... 9

2.5 O ácaro do coqueiro, Aceria guerreronis Keifer (Prostigmata: Eriophyidae) • 12

2.5.1 Histórico e importância econômica ............................................................. 12

2.5.2 Origem e hospedeiros de A. guerreronis .................................................. 16

2.5.3 Medidas de controle e manejo de A. guerreronis ........................................ 18

3 ÁCAROS ERIOPHYOIDEA (ACARI: PROSTIGMATA) ASSOCIADOS A PALMEIRAS (ARECACEAE) EM ALGUMAS ÁREAS DAS AMÉRICAS ... 24

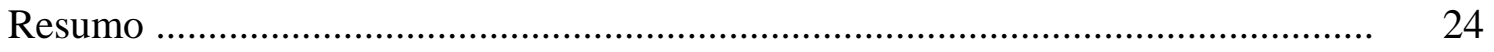

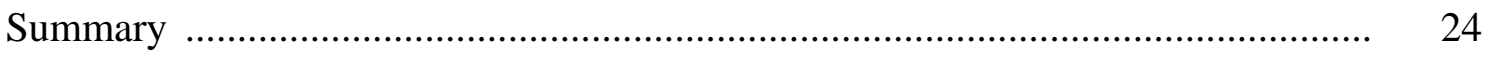

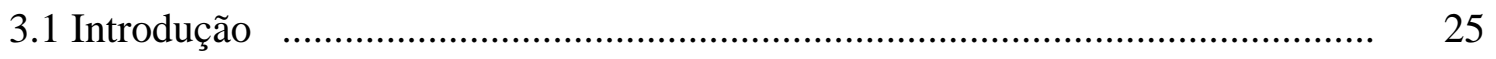

3.2 Revisão de Literatura .................................................................................. 27

3.2.1 Eriophyoidea, especificidade hospedeira $\quad$................................................. 28

3.2.2 Espectro de hospedeiros de A. guerreronis ................................................. 29

3.2.3 Ácaros Eriophyoidea associados a palmeiras no Brasil, Costa Rica e México. 30

3.3 Material e Métodos ................................................................................... 32 
3.3.1 Prospeç̧ão de campo ………………………......................................... 33

3.3.2 Inspeção acarológica e preservação dos ácaros Eriophyoidea ........................ 38

3.3.3 Identificação dos ácaros Eriophyoidea associados às palmeiras ...................... 38

3.4 Resultados e Discussão ............................................................................ 39

3.5 Conclusões .......................................................................................... 56

4 NOVOS GÊNEROS E ESPÉCIES DE ÁCAROS ERIOPHYIDAE E PHYTOPTIDAE (PROSTIGMATA: ERIOPHYOIDEA) ASSOCIADOS A

PALMEIRAS (ARECACEAE) ………………………………………….... 57

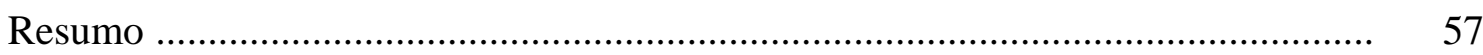

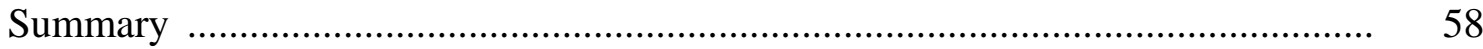

4.1 Introdução ……………………………………………………………..... 59

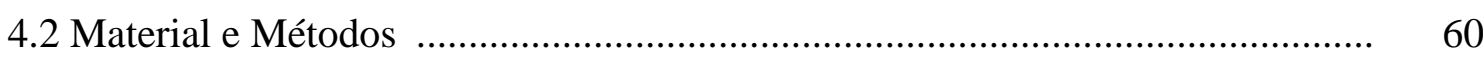

4.3 Resultados e Discussão ……………………………………………………... 61

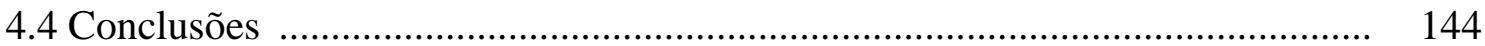

5 ÁCAROS ERIOPHYOIDEA (PROSTIGMATA) ASSOCIADOS A

PALMEIRAS (ARECACEAE) NO MUNDO: HOSPEDEIROS, DISTRIBUIÇÃO GEOGRÁFICA E CHAVE PARA IDENTIFICAÇÃO ....... 145

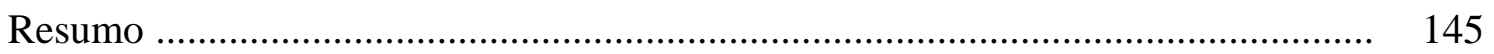

Summary ……................................................................................. 146

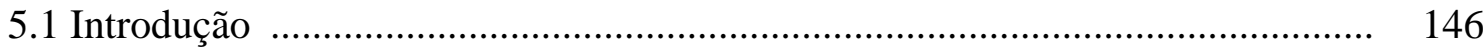

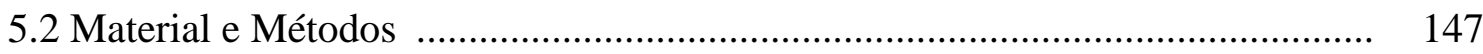

5.3 Resultados e Discussão ................................................................................. 148

5.4 Conclusões ............................................................................................. 187

6 O ÁCARO DO COQUEIRO, ACERIA GUERRERONIS KEIFER (ACARI: ERIOPHYIDAE) - FILOGEOGRAFIA BASEADA EM SEQÜÊNCIAS DE DNA RIBOSSOMAL (ITS) E MITOCONDRIAL (16S e CO-I ) ..................... 188

Resumo ……........................................................................................... 188

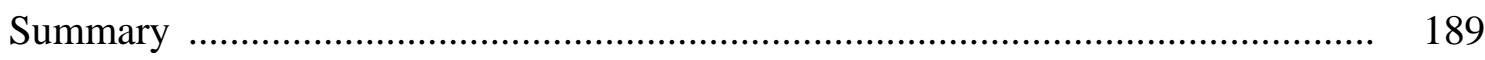

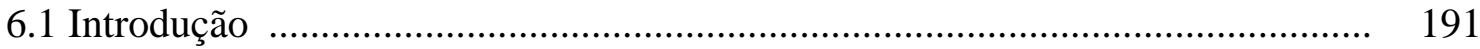

6.2 Revisão de Literatura .................................................................................... 195 
6.2.1 Genética molecular em estudos filogenéticos e filogeográficos ................... 195

6.2.2 Marcadores moleculares em estudos de filogenética molecular .................... 197

6.2.3 Estudos filogeográficos e bioinvasões .................................................... 200

6.2.4 Marcadores moleculares em estudos com ácaros plantícolas ....................... 201

6.2.5 Métodos em análise filogenética molecular ............................................. 205

6.3 Material e Métodos ................................................................................ 208

6.4 Resultados e Discussão .............................................................................. 215

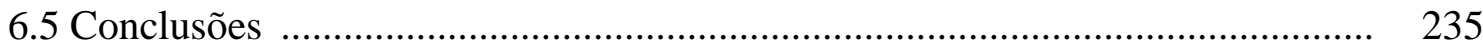

7 PADRÃO GEOGRÁFICO DE VARIAÇÃO MORFOMÉTRICA DE POPULAÇÕES DO ÁCARO DO COQUEIRO, ACERIA GUERRERONIS KEIFER (PROSTIGMATA: ERIOPHYIDAE), UTILIZANDO MORFOMETRIA MULTIVARIADA ....................................................... 236

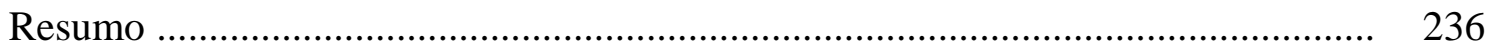

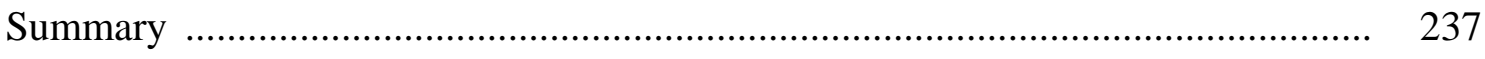

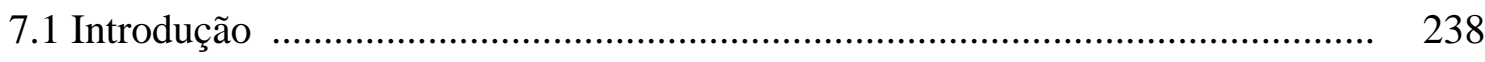

7.2 Revisão de Literatura ............................................................................... 240

7.2.1 Morfometria multivariada ................................................................. 240

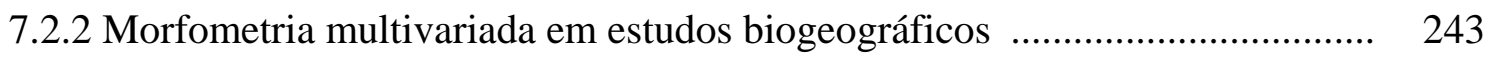

7.2.3 Morfometria multivariada em acarologia ............................................... 245

7.2.4 Estudos morfométricos na sistemática de Eriophyoidea ............................. 248

7.3 Material e Métodos ................................................................................... 249

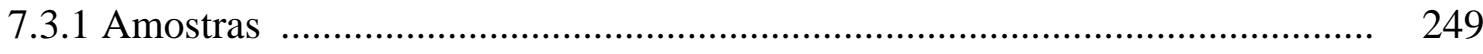

7.3.2 Avaliações morfológicas ....................................................................... 250

7.3.3 Análises estatísticas .............................................................................. 253

7.4 Resultados e Discussão ......................................................................... 256

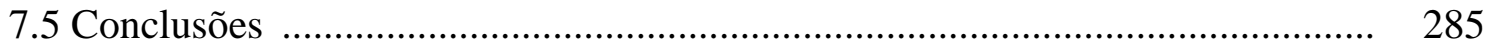

8 DETERMINAÇÃO DA VARIAÇÃO MORFOLÓGICA ENTRE POPULAÇÕES

DO ÁCARO DO COQUEIRO, ACERIA GUERRERONIS KEIFER (PROSTIGMATA: ERIOPHYIDAE), UTILIZANDO MORFOMETRIA GEOMÉTRICA …............................................................................. 286 
Resumo

286

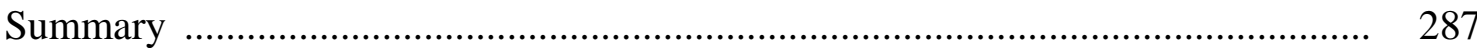

8.1 Introdução .............................................................................................. 288

8.2 Revisão de Literatura ................................................................................. 290

8.2.1 Morfometria geométrica ................................................................... 290

8.2.2 Análise de deformações (Thin- plate splines) .............................................. 292

8.2.3 Morfometria geométrica \& morfometria multivariada tradicional ................ 293

8.2.4 Utilização da morfometria geométrica ...................................................... 295

8.2.5 Morfometria geométrica em acarologia ................................................. 296

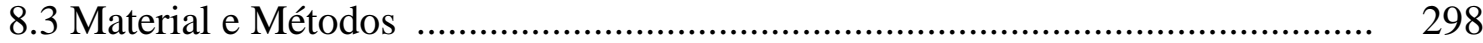

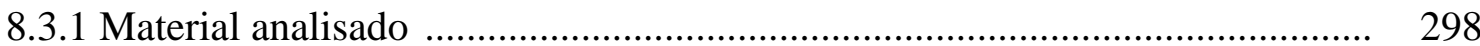

8.3.2 Avaliações morfológicas ...................................................................... 299

8.3.3 Análises de morfometria geométrica ........................................................ 304

8.4 Resultados e Discussão ............................................................................... 306

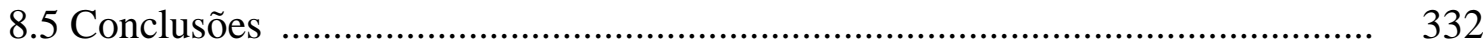

9 ÁCAROS FITÓFAGOS E PREDADORES ASSOCIADOS A FRUTOS DE COCO (Cocos nucifera L.) DE ALGUMAS LOCALIDADES DAS AMÉRICAS

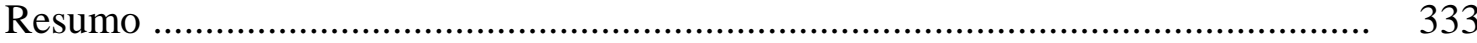

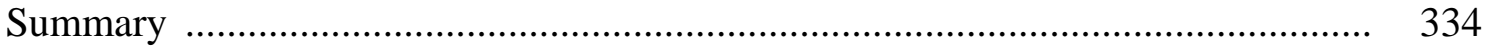

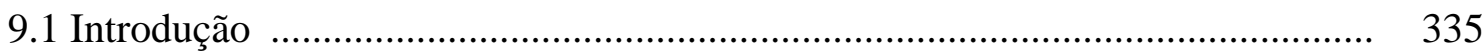

9.2 Revisão de Literatura ............................................................................... 336

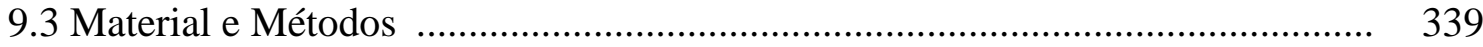

9.4 Resultados e Discussão ................................................................................. 340

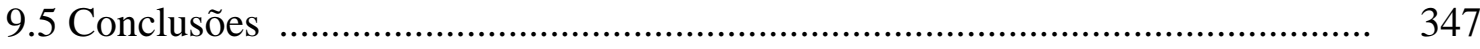

10 CONCLUSÕES GERAIS ................................................................... 348

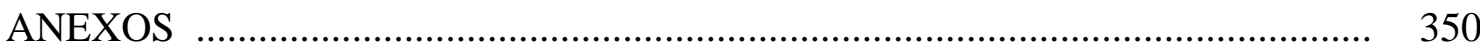

REFERÊNCIAS BIBLIOGRÁFICAS ......................................................... 402 


\title{
ÁCAROS ERIOPHYOIDEA (PROSTIGMATA) ASSOCIADOS A PALMEIRAS (ARECACEAE), COM ÊNFASE NO ÁCARO DO COQUEIRO, ACERIA GUERRERONIS KEIFER - ESPECTRO DE HOSPEDEIROS E ASPECTOS BIOGEOGRÁFICOS
}

\author{
Autora: DENISE NÁVIA MAGALHÃES FERREIRA \\ Orientador: Prof. Dr. GILBERTO JOSÉ DE MORAES
}

\section{RESUMO}

Muito pouco se conhece sobre os ácaros Eriophyoidea associados às palmeiras no Brasil e em outras partes do mundo. O ácaro do coqueiro, Aceria guerreronis Keifer (Prostigmata: Eriophyidae), representa uma das principais pragas desta cultura em diversas regiões produtoras. Informações sobre o espectro de hospedeiros, região de origem e fontes de recentes introduções deste ácaro são importantes para orientar a prospecção de agentes de controle biológico e a adoção de medidas quarentenárias. Levantamentos de ácaros Eriophyoidea em palmeiras podem fornecer novas informações sobre o espectro de hospedeiros de A. guerreronis. O conhecimento da acarofauna associada às palmeiras também pode fornecer subsídios ao reconhecimento futuro destes ácaros em cultivos comerciais de palmeiras. No presente estudo, realizouse um levantamento de Eriophyoidea em 191 espécies de palmeiras (nativas e introduzidas) de algumas localidades da América. Foram coletadas 38 espécies de Eriophyoidea, mas $A$. guerreronis não foi encontrada em nenhuma das amostras analisadas, exceto no coqueiro, Cocos nucifera L.. Relatos de novos hospedeiros e novas localidades de ocorrência são apresentados. Dentre os 26 táxons identificados 
como novos, foram descritos três novos gêneros e 17 novas espécies. Com o objetivo de facilitar estudos futuros, foram reunidas informações, publicadas e novas (adquiridas durante o desenvolvimento deste projeto), sobre as espécies de Eriophyoidea associadas às palmeiras no mundo, e uma chave dicotômica para auxiliar na separação das mesmas foi elaborada. Visando a obtenção de informações sobre aspectos biogeográficos de $A$. guerreronis, foram realizadas análises filogeográficas, baseadas em seqüências de DNA ribossomal (ITS) e mitocondrial (16S e CO-I), e morfométricas, utilizando técnicas de morfometria multivariada tradicional [Análise dos Componentes Principais (ACP) e Análise de Variáveis Canônicas (AVC)] e morfometria geométrica [Análise de Deformações Relativas (ADR), utilizando a função Thin-plate splines], de 29 populações ao longo de sua área de ocorrência na América, África e Ásia. As análises filogenéticas foram realizadas utilizando-se probabilidade máxima, parcimônia máxima e inferência Bayesiana. ACPs e ADCs foram conduzidas para seis combinações de populações (Brasil; América; América \& África; América \& Ásia; África \& Ásia e América, África \& Ásia). ADR foram aplicadas às regiões do escudo dorsal, coxi-genital e ventral de A. guerreronis. As matrizes de peso das ADR aplicadas aos indivíduos de todas as populações foram analisadas através de AVC. Os resultados das análises filogeográficas e morfométricas foram concordantes e são consistentes com o possível histórico de disseminação e invasões de A. guerreronis e com a hipótese de que o coqueiro não seja seu hospedeiro original. Estes resultados sugerem que A. guerreronis apresenta origem americana, que a introdução na África ocorreu a partir de um número reduzido de indivíduos, e que possivelmente a introdução na Ásia se deu a partir de populações africanas ou tenha a mesma população fonte que estas. Visando a aquisição de espécimes de A. guerreronis para o estudo da variabilidade genética e morfológica de populações, foram inspecionadas amostras de frutos de coco de diversas localidades da América. Vários outros ácaros além de A. guerreronis foram também coletados e identificados. Os sintomas observados nos frutos infestados pelas diferentes espécies fitófagas foram descritos. 


\title{
ERIOPHYOIDEA MITES (PROSTIGMATA) ASSOCIATED WITH PALM TREES (ARECACEAE), WITH EMPHASIS ON THE COCONUT MITE, ACERIA GUERRERONIS KEIFER - HOST RANGE AND BIOGEOGRAPHICAL ASPECTS
}

\author{
Author: DENISE NÁVIA MAGALHÃES FERREIRA \\ Adviser: Prof. Dr. GILBERTO JOSÉ DE MORAES
}

\section{SUMMARY}

Little is known about the Eriophyoidea mites associated with palm trees in Brazil and other parts of the world. The coconut mite, Aceria guerreronis Keifer (Prostigmata: Eriophyidae), represents a major pest of this crop in several production areas. Information on host range, region of origin and sources of recent introductions of this mite are important aspects to guide prospections of biological control agents and adoption of quarantine measures. Surveys of Eriophyoidea mites on palm trees can provide new information on the host range of $A$. guerreronis. Knowledge on the mite fauna associated with palms can be useful in their future recognition in commercial palm crops. A survey of the Eriophyoidea on 191 palm species (native and introduced) was conducted in some localities of America in this study. Thirty-eight Eriophyoidea species were collected, but $A$. guerreronis was not found. Reports of new hosts and new localities of occurrence were presented. Of 26 taxa identified as new, three new genus and 17 new species were described. With the objective to facilitate future studies, published and new (acquired during development of this project) information on Eriophyoidea mites associated with palms was summarized and a dichotomous key to 
help in the separation of those mites was prepared. To obtain information on biogeographical aspects of A. guerreronis, phylogeographical analyses, based on ribosomal (ITS) and mitochondrial (16S e CO-I) DNA, and morphometrical analyses, using traditional multivariate morphometry [Principal Component Analysis (PCA) and Canonical Variables Analysis (CVA)] and geometric morphometry techniques [Relative Warp Analysis (RWA) through Thin-plate splines function] of 29 populations, along its occurrence area in America, Africa and Asia, were conducted. Phylogenetic analyses were conducted using maximum likelihood, maximum parsimony and Bayesian inferences. PCAs and CVAs were conducted with six combinations of populations (Brazil; America; America \& Africa; America \& Asia; Africa \& Asia and America, Africa \& Asia) were conducted. RWAs were applied to prodorsal shield, coxi-genital and ventral regions of A. guerreronis. Weight matrixes of RWA applied to specimens of all populations were analyzed through CVA. Results of phylogeographical and morphometric analyses were compatible and are consistent with the possible historic of dissemination and invasion of $A$ guerreronis history and with the hypothesis that the coconut is not the original host of this mite. These results suggest that $A$. guerreronis has an American origin; that few individuals were introduced to Africa; that populations introduced to Asia probably originated in Africa or had the same source as the African populations. Aiming to acquire A. guerreronis specimens for the genetic and morphological variability studies, coconut fruits from several localities in America were inspected. Several other mites were also collected and identified. Symptoms observed on the fruits infested by different phytophagous species were described. 


\section{INTRODUÇÃO}

Arecaceae é uma das famílias de plantas com maior número de espécies, as quais são muito abundantes nas regiões tropicais e subtropicais, sendo genericamente conhecidas como palmeiras. Além de serem amplamente utilizadas como ornamentais em todo o mundo, apresentam grande importância sócio-econômica nas regiões de maior ocorrência, onde o cultivo de diversas espécies vem se expandindo rapidamente (Henderson et al., 1995; Lorenzi, 1996).

Muitas espécies de ácaros fitófagos são importantes pragas agrícolas por todo o mundo (Yaninek \& Moraes, 1991), especialmente aquelas que têm sido transferidas de suas áreas de origem para novas áreas, sem serem acompanhadas por seus inimigos naturais. Outras espécies de ácaros alcançaram o status de praga devido a modificações em seu habitat que os tornaram mais adequados ao desenvolvimento da praga ou menos adequados ao desenvolvimento de seus inimigos naturais. Deste modo, ácaros fitófagos associados a hospedeiros cujas culturas vem se expandindo representam pragas potenciais destas. O conhecimento dos ácaros fitófagos e de suas interações com os inimigos naturais em seu habitat natural pode possibilitar um melhor manejo dos agroecossistemas.

Os ácaros Eriophyoidea (Prostigmata) são estritamente fitófagos e apresentam uma grande especificidade em relação ao hospedeiro. Várias espécies deste grupo, especialmente as pertencentes à família Eriophyidae, apresentam grande importância econômica como pragas por todo o mundo (Lindquist et al., 1996). Além dos danos físicos diretos causados às plantas hospedeiras, podem agir como vetores de fitopatógenos. Até 2003, foram listadas 3442 espécies de Eriophyoidea em 301 gêneros (Amrine et al., 2003). Nos últimos vinte anos tem sido observado um aumento notável no número de novos táxons desta superfamília. Este incremento demonstra o conhecimento limitado do grupo, 
que é menos conhecido em certas regiões geográficas, incluindo a região Neotropical. Estima-se que apenas cerca de 5\% dos Eriophyoidea tenham sido descritos até o momento (Amrine \& Stasny, 1994). A importância econômica destes ácaros vem crescendo em escala mundial e seu êxito em colonizar novas áreas faz com que sejam considerados como um grupo de importância quarentenária.

Muito pouco se conhece sobre os ácaros Eriophyoidea associados a palmeiras no Brasil e, de um modo geral, no mundo. Das 3500 espécies que constituem o grupo das palmeiras (Lorenzi, 1996), são relatados ácaros eriofiídeos em apenas cerca de 50 espécies (Amrine \& DeLillo, 2003).

Considerando a importância econômica atual e potencial das palmeiras e dos ácaros Eriophyoidea como pragas, conclui-se pela necessidade de ampliar o conhecimento sobre os ácaros desta superfamília associados às palmeiras.

Entre as palmeiras, o coqueiro, Cocos nucifera L., destaca-se como uma das espécies de maior importância agrícola do mundo. Além de sua importância econômica, representa um componente fundamental para as populações nas regiões onde é cultivado sendo conhecido como “árvore da vida”. Todas as partes desta planta podem ser utilizadas para a preparação de bebidas e alimentos, para a extração de óleo e diferentes produtos químicos, fabricação de utensílios domésticos etc.

O ácaro do coqueiro, Aceria guerreronis Keifer, 1965 (Prostigmata: Eriophyidae), representa uma das principais pragas desta cultura em diversas regiões produtoras (Moore \& Howard, 1996). As primeiras infestações deste ácaro foram relatadas na América, especialmente no México, Colômbia, Venezuela e Brasil, e nas costas leste e oeste da África. Recentemente, foram relatadas altas infestações por este eriofiídeo no sudeste asiático, India e Sri Lanka, importante região de produção de coco a nível mundial, onde vem causando sérios problemas à cultura. Este ácaro é considerado uma espécie invasora que tem se disseminado e estabelecido rapidamente em importantes áreas de produção, sendo considerado uma praga chave da cultura do coco na maioria delas. O ácaro do coqueiro representa uma ameaça para os países da Oceania e para outros países da Ásia onde sua presença ainda não foi relatada, devendo-se adotar medidas quarentenárias para evitar sua disseminação. O controle químico deste eriofiídeo usualmente não é praticável. 
As maiores perspectivas para o controle de A. guerreronis correspondem à viabilização do controle biológico, especialmente do controle biológico clássico, cujo passo inicial corresponde à prospecção de agentes controladores na região de origem da praga.

Há indicações de que o hospedeiro original de A. guerreronis não seja o coqueiro, mas sim uma outra palmeira nativa da América ou da África, e que este eriofiídeo tenha passado a atacar o coqueiro há relativamente pouco tempo.

A região de origem de uma espécie de praga freqüentemente corresponde à região de origem de seu hospedeiro original. No caso de A. guerreronis, por não se conhecer o seu hospedeiro original e pelos relatos de ocorrência da espécie terem se dado quase que simultaneamente em países/continentes distintos, não se dispõe de informação sobre sua região de origem.

O conhecimento de aspectos básicos sobre o ácaro do coqueiro é importante para o desenvolvimento de um programa de controle biológico clássico bem como para orientar a adoção de medidas quarentenárias. Informações sobre o espectro de hospedeiros e região de origem do ácaro são fundamentais para orientar a prospecção de agentes de controle biológico. O conhecimento sobre a origem e fonte de recentes introduções do ácaro do coqueiro, bem como sobre seu espectro de hospedeiros, deve ser considerada para a escolha de medidas quarentenárias eficazes.

Levantamentos de ácaros eriofiídeos em palmeiras poderão trazer novas informações sobre o espectro de hospedeiros de A. guerreronis, sobre seu hospedeiro original e, conseqüentemente, sobre sua possível região de origem. Indicações sobre a área de origem de $A$. guerreronis também podem ser adquiridas a partir de estudos sobre a variabilidade genética e fenotípica de populações ao longo de sua área de distribuição geográfica. 


\section{REVISÃO DE LITERATURA}

\subsection{As palmeiras - diversidade, habitat e importância sócio-econômica}

As palmeiras são plantas monocotiledôneas da família Arecaceae (anteriormente denominadas Palmaceae ou Palmae), pertencentes à ordem Arecales (Jones, 1995). As Arecaceae, genericamente conhecidas como palmeiras, são extremamente diversas e compõem uma das maiores famílias de plantas. São representadas por cerca de 3.500 espécies reunidas em mais de 240 gêneros (Lorenzi, 1996). Os registros fósseis mais antigos são do final do Cretáceo, mas podem ter existido mesmo antes deste período (Jones, 1995).

Apesar de serem amplamente distribuídas por todo o mundo, de $44^{\circ} \mathrm{N}$ a $44^{\circ} \mathrm{S}$, do nível do mar até $4000 \mathrm{~m}$ de altitude e de florestas tropicais a áreas desérticas, as palmeiras simbolizam popularmente a paisagem tropical. Isso se deve ao fato da grande maioria das espécies ocorrer nos trópicos, muitas vezes como componentes dominantes da vegetação. Muitos gêneros de palmeiras apresentam ocorrência localizada em pequenas áreas, indicando habilidade de ocupação de nichos específicos. Sua distinta aparência e simples arquitetura fazem com que as pessoas as reconheçam facilmente. Por sua beleza, porte e distinção, as palmeiras são reconhecidas como “príncipes” entre as plantas e foram assim primeiramente denominadas pelo botânico sueco Carolus Linnaeus (Jones, 1995).

As palmeiras são de grande interesse para o paisagismo, sendo amplamente utilizadas como plantas ornamentais, em jardins, avenidas de cidades e mesmo no interior de ambientes. Além disto, apresentam grande importância sócio-econômica. 
Juntamente com os legumes e gramíneas, representam um dos grupos de plantas mais úteis ao homem, pelos diferentes produtos que delas podem ser obtidos e pelo elevado número de espécies de importância econômica (Henderson et al., 1995; Lorenzi, 1996). Em comunidades indígenas, por exemplo, os caules são utilizados no piso e parede de casas, a palha é utilizada na cobertura de construções, os frutos fornecem alimento e bebida, o óleo extraído das palmeiras enriquece a dieta. Além disso, materiais extraídos das palmeiras são utilizados para confeccionar brinquedos e roupas, para ornamentar o corpo e em rituais religiosos (Henderson et al., 1995). Por serem espécies perenes, são apropriadas ao sistema auto-sustentável de exploração.

Já foram assinaladas no Brasil 284 espécies de arecáceas, sendo 132 nativas e 152 exóticas. As espécies de maior importância econômica no país são o coqueiro (Cocos nucifera L.); os palmitos açaí (Euterpe oleraceae Mart.), juçara (Euterpe edulis Mart.) e pupunha (Bactris gasipaes Kunth); a carnaúba (Copernicia prunifera (Miller) H. E. Moore); o babaçu (Attalea speciosa Mart. Ex Spreng); o buriti (Mauritia flexuosa L.) e o dendezeiro (Elaeis guineensis N. J. Jacquin) (Lorenzi, 1996).

\subsection{Origem e disseminação do coqueiro, Cocos nucifera $\mathrm{L}$.}

O coqueiro, considerado a mais importante palmeira do trópico úmido, ocorre há muito tempo nos hemisférios oriental e ocidental. Sua distribuição e antiga ocorrência em ambos tem dificultado a determinação de seu centro de origem.

A hipótese da origem do coqueiro na costa oeste da América central foi levantada pelo naturalista Von Martius (Historia Naturalis Palmarum, 1823-50), baseada no argumento de que todas as outras espécies do gênero Cocos, assim como outros gêneros próximos a este, foram encontrados na América (Child, 1974). Cook ${ }^{1}$ citado por Child (1974) também defendeu a hipótese da origem americana do coqueiro,

${ }^{1}$ COOK, O.F. The origin and distribution of the cocoa palm. Contribution from the US National Herbarium, v.7, p.257-293, 1901. 
considerando a possibilidade de que os agricultores primitivos que disseminaram o coqueiro e outras plantas nas ilhas e praias do Oceano Pacífico e Índico tenham vindo originariamente da América. Este autor também sugere que registros históricos relatam a presença do coqueiro em Cuba, Porto Rico, Brasil e Colômbia, bem antes de sua introdução pelos hispanos.

A argumentação de Von Martius (Historia Naturalis Palmarum, 1823-50) de que as outras espécies do gênero Cocos e de que gêneros próximos a Cocos eram encontrados na América foi enfraquecida com a descoberta de espécies próximas a $C$. nucifera em outros continentes, como Jubaeopsis caffra Becc., na África do Sul, e espécies do gênero Beccariophoenix Jumelle \& Perrier, em Madagascar (Child, 1974).

A descoberta de fósseis de espécies de Cocos nos depósitos do Plioceno em Mangonui, North Auckland, Nova Zelândia, chamado de Cocos zeylandica por Berry 1926 suporta a hipótese da origem oriental do coqueiro (Harries ${ }^{2}$ citado por Persley, 1992).

Atualmente, admite-se a hipótese de que embora o ancestral do coqueiro tenha sido da América do Sul, tenha se dispersado amplamente milhões de anos antes de sua domesticação na área Indo-Pacífica (Harries ${ }^{3}$ citados por Persley, 1992). Há evidências convincentes de que o coqueiro tenha se dispersado através da flutuação de frutos em correntes oceânicas e germinado após lavagem em terra firme em novas localidades. Concebe-se também que o coco tenha sido transportado pelo homem como fonte de alimento e bebida em longas movimentações (Persley, 1992).

O coqueiro tem estado presente na maioria das Ilhas do Pacífico há milhões de anos, muito antes da sua colonização pelos polinésios. Tem sido registrada sua presença

2 HARRIES, H. C. The evolution, dissemination and classification of Cocos nucifera L. Botanical Review, v.44, p.265-320, 1978.

${ }^{3}$ HARRIES, H. C. Coconut Cocos nucifera L. In: SMART, J. (Org.). Evolution of Crop Plants. Simmonds, 1992.

${ }^{4}$ HARRIES, H. C. Coconut. In: MACRAE, R. (Org.). Encyclopedia of Food Science and Nutrition. London: Academic Press, 1992. 
há 2000-3000 anos na costa do Sri Lanka e sul da Índia e há menos de 500 anos no oeste da África e das Américas (Purseglove ; Harries $^{2}$ citados por Persley, 1992).

A disseminação de $C$. nucifera por flutuação provavelmente levou à colonização de áreas remotas e geograficamente isoladas por poucas plantas. Sob estas condições, as populações podem ter sofrido restrições genéticas devido ao efeito de genetic drift, o que explicaria os baixos níveis de diversidade intra-populacional encontrados na região do Sul do Pacífico. Por outro lado, o isolamento reprodutivo levou a uma marcante diferenciação entre populações, o que explicaria a alta porcentagem de diversidade interpopulacional e o fato do pool genético desta espécie ser fragmentado e distribuído nas diversas ilhas, atóis e lugares remotos da região (Zizumbo-Villarreal \& Quero, 1998).

Estudos recentes sobre a diversidade genética, disseminação e domesticação do coqueiro utilizando marcadores moleculares também suportam a hipótese da origem oriental do coqueiro, na região Indo-Pacífica, onde se observa o maior polimorfismo entre as populações (Lebrun et al., 1998ab).

\subsection{Produção, utilização e importância sócio-econômica do coqueiro}

O coqueiro é cultivado em aproximadamente 11,6 milhões de hectares distribuídos por cerca de 86 países. Sua área de produção tem aumentado nas últimas décadas em aproximadamente 2\% ao ano (Persley, 1992).

As principais áreas de produção encontram-se na Ásia e ilhas do Pacífico, onde se encontram cerca de $85 \%$ dos cultivos. O coco também é importante em áreas litorâneas e ilhas na América, onde se concentra cerca de 7\% da produção mundial (Persley, 1992). Os principais países produtores são Indonésia, Filipinas, Índia, Sri Lanka, Tailândia, México, Malásia e Vietnam (FAO, 1999). Há cerca de 32 países produtores na América, da Florida (EUA) ao Brasil, sendo que os principais produtores são México e Brasil (Persley, 1992). Além disto, também é de importância em áreas

\footnotetext{
${ }^{5}$ PURSEGLOVE, J. W. Tropical crops: monocotyledons. London: Longmans, 1975. p.440-479.
} 
litorâneas de 22 países no leste e oeste da África e em ilhas do Oceano Índico. Os principais produtores africanos são Costa do Marfim, Moçambique e Tanzânia. A produção de coco das ilhas do Oceano Índico corresponde a cerca de 6\% da produção mundial (Persley, 1992).

Observa-se que o coco é predominantemente uma cultura de pequenos produtores, sendo sua produção voltada para o consumo local das regiões de produção. Cerca de 96\% da produção é proveniente de áreas de 0,2 a 4,0 ha. Aproximadamente $70 \%$ da produção total asiática é consumida nos países produtores. Nas Ilhas do Pacífico, onde as populações humanas são menores, cerca de $30 \%$ da produção é consumida localmente e 70\% é exportado (Persley, 1992).

Estimativas da "Asian and Pacific Coconut Community (APCC)" indicam que há mais de 10 milhões de famílias de agricultores diretamente envolvidas no cultivo do coco no mundo, o correspondente a aproximadamente 50 milhões de pessoas. Apenas na Ásia, 30 milhões de pessoas dependem diretamente da produção e/ou processamento do coco para sua sobrevivência. Nas Filipinas, cerca de um terço da população é diretamente dependente da cultura do coco para sobrevivência. Em Sri Lanka, a indústria do coco é a principal fonte de emprego e é a segunda em importância como cultura agrícola (Persley, 1992).

No Brasil, o coco é produzido principalmente na Região Nordeste e, recentemente, também na Região Norte. Os frutos verdes são colhidos para consumo direto da água-de-coco. Grande parte da produção é destinada à fabricação de alimentos industrializados, especialmente leite-de-coco e coco ralado. As folhas dos coqueiros são utilizadas em construções e para confecção de artesanato (Cuenca, 1994).

No sudeste asiático e nas Ilhas do Pacífico, os produtos derivados do coqueiro mais importantes a nível comercial são: leite-de-coco, copra, óleo de coco, coco desidratado, fibra e carvão. Os produtos químicos derivados do coco que estão se tornando cada vez mais importantes e valiosos são metilésteres, álcoois graxos e glicerina. O coco e o leite-de-coco são consumidos diariamente pelos habitantes das áreas de produção. O óleo de coco é utilizado para cozimento, iluminação, lubrificação, manufatura de margarina, produtos de padaria, gordura, sabões, detergentes e 
cosméticos. O resíduo do coco, após a remoção do óleo da copra, é utilizado em rações animais. A madeira pode ser utilizada em estruturas de construções e para a manufatura de móveis, enquanto as folhas são utilizadas na cobertura de construções. As fibras da casca são utilizadas para confecção de cordas e esteiras ou produção de carvão (Ohler, 1999; Persley, 1992).

\subsection{Eriophyoidea - aspectos gerais e importância econômica}

Os ácaros pertencentes à superfamília Eriophyoidea, encontram-se na ordem Prostigmata (= Actinedida) e formam um grupo de Acari distinto e bem sucedido. Esta superfamília é composta por três famílias: Eriophyidae (227 gêneros), Diptilomiopidae (53 gêneros) e Phytoptidae (21 gêneros) (Amrine Jr. et al., 2003). Um ácaro fóssil, de 37 milhões de anos, encontrado na Austrália, apresenta as mesmas características morfológicas dos eriofiídeos atuais. Estes ácaros apresentam um alto grau de especialização morfológica e biológica e anatomia simplificada devido à perda de estruturas (Lindquist \& Amrine Jr., 1996).

No catálogo de autoria de Davis et al. (1982), foram listadas 1859 espécies de Eriophyoidea do mundo, distribuídos em 156 gêneros. Doze anos depois daquela publicação, Amrine \& Stasny (1994) publicaram um segundo catálogo contendo os Eriophyoidea do mundo, relatando 2884 espécies. Poucos anos depois, Amrine (1996) relatou ser esta superfamília composta por 3030 espécies em 237 gêneros. Finalmente, Amrine et al. (2003) relatou ser esta superfamília composta por 3442 espécies válidas, distribuídas em 301 gêneros. Este aumento notável no número de novos táxons em menos de quinze anos demonstra um pobre conhecimento do grupo e também o quão rica em táxons é esta superfamília. Mais da metade das espécies conhecidas até 1996 haviam sido descritas da América do Norte e da Europa (Oldfield, 1996). Muito pouco se sabe sobre estes ácaros em outras partes do mundo, inclusive nas florestas tropicais na América do Sul, onde se encontra a maior diversidade florística do mundo. Amrine \& 
Stasny (1994) estimaram que não mais de 5\% das espécies que existem no mundo foram descritas até o momento.

Os Eriophyoidea são ácaros vermiformes ou fusiformes, bastante pequenos. O corpo destes ácaros é apropriado para permitir a ocupação de locais confinados nos hospedeiros, como bainhas de folhas, gemas, galhas, eríneas etc. Os adultos medem em média $200 \mu \mathrm{m}$, variando de 80 a $500 \mu \mathrm{m}$. Além da redução em tamanho, apresentam também uma redução nas estruturas do corpo, apresentando apenas dois pares de pernas e poucas setas idiossomais. É possível reconhecer três divisões básicas no corpo dos eriofiídeos: gnatossoma ou rostro, onde encontram-se os estiletes quelicerais; propodossoma, onde estão os dois pares de pernas; e opistossoma, anelado transversalmente. A abertura genital é proximal, localizada atrás do segundo par de coxas, em ambos os sexos. Detalhes sobre anatomia externa e notação de estruturas utilizadas na sistemática do grupo podem ser encontrados em Lindquist \& Amrine Jr. (1996).

Os Eriophyoidea são fitófagos obrigatórios, assim como os Tetranychoidea. Alimentam-se basicamente com um par de estiletes quelicerais, com os quais perfuram as células vegetais (Flechtmann, 1975; Lindquist \& Amrine Jr., 1996).

Uma característica geral para a maioria das espécies de Eriophyoidea é sua especificidade em relação à planta hospedeira, o que reflete uma íntima relação ácaroplanta. A maioria das espécies descritas é relatada de um único hospedeiro e outras limitam-se a plantas de um único gênero; algumas espécies desenvolvem-se sobre plantas de gêneros próximos. São raros os eriofiídeos que se reproduzem sobre espécies de famílias diferentes. Mais de 1800 espécies de plantas, em cerca de 850 gêneros e 200 famílias foram relatadas como hospedeiras de Eriophyoidea (Oldfield, 1996).

A maioria dos Eriophyoidea passa pelos estágios de ovo, larva, ninfa e adulto. Entre a larva e a ninfa e entre a ninfa e o adulto ocorre um estágio quiescente (Flechtmann, 1975). Há, entretanto, relatos de espécies em que as fêmeas dão origem a larvas sendo, portanto, ovovivíparas (Abou-Awad, 1981; De Lillo, 1991). Este ciclo de vida simples ocorre em Eriophyoidea que vivem em gemas e plantas perenes não caduciformes, de regiões tropicais. Algumas espécies de eriofiídeos que vivem em 
plantas de folhas decíduas, em regiões de clima temperado, apresentam alternância de gerações, em que machos e fêmeas são encontrados durante a época favorável do ano ao seu desenvolvimento, sendo as fêmeas parecidas com os machos conhecidas como protoginas; e outra em que apenas fêmeas são encontradas, durante a época desfavorável do ano ao seu desenvolvimento, sendo estas bastante distintas das protoginas e conhecidas como deutoginas (Flechtmann, 1975; Manson \& Oldfield, 1996).

Em termos de importância econômica como ácaros-praga em agroecossistemas, os Eriophyoidea estão atrás apenas dos Tetranychoidea. Todas as partes das plantas podem ser infestadas pelos Eriophyoidea, exceto as raízes (Westphal \& Manson, 1996). Os sintomas causados pela infestação por eriofiídeos podem ser diversos, alguns dos quais resultantes da ação de componentes da saliva que injetam nas células de que se alimentam. As anormalidades mais usuais causadas por Eriophyoidea são: bronzeamento ou prateamento de folhas e frutos; descoloração de tecidos que apresentam manchas amareladas ou cloróticas; modificação no crescimento de estruturas vegetais, induzidas no tecido embrionário, resultando em pústulas ou eríneos (proliferação anormal de tricomas); enrolamento da borda das folhas; galhas, muitas vezes semelhantes a tumores; e malformação ou proliferação de gemas (superbrotamento) (Jeppson et al., 1975; Flechtmann, 1975; Westphal \& Manson, 1996). Além dos danos causados pela alimentação, os Eriophyoidea são importantes vetores de patógenos de plantas. São conhecidos diversos agentes fitopatogênicos transmitidos por estes ácaros, a maioria para gramíneas e frutíferas (Oldfield \& Proeseler, 1996).

Por meios naturais, o mais eficiente agente de dispersão dos Eriophyoidea é o vento. Fêmeas e alguns machos freqüentemente se prendem à região apical ou à borda das folhas através de seus lobos terminais, permanecendo perpendiculares à superfície destas. Este comportamento parece ajudar na dispersão pelo vento. Nesta posição, podem também formar correntes de vários indivíduos. Algumas espécies podem saltar, projetando-se no ar. Com o incremento do intercâmbio e comércio internacional de produtos de origem vegetal, o homem tem sido um importante disseminador destes ácaros a longas distâncias, através do transporte de partes de plantas infestadas, como frutos, flores, borbulhas, estacas, mudas, sementes etc (Flechtmann, 1975). As reduzidas 
dimensões e a localização em regiões protegidas no hospedeiro dificultam sobremaneira a detecção e interceptação destes ácaros em pontos de entrada nos países passando despercebidos a uma inspeção superficial (Navia, 1997).

Há um grande número de espécies de Eriophyoidea que alcança status de praga em agroecossistemas, sendo necessária a utilização de medidas de controle nas culturas infestadas para manter as populações abaixo dos níveis de dano econômico. Entre as culturas mais seriamente infestadas por Eriophyoidea destacam-se algumas frutíferas (citros, maçã, pêra, pêssego, framboesa, groselha, uva, manga e coco), gramíneas (trigo, milho, cana-de-açúcar), café, chá, tomate, alho e diversas plantas ornamentais (Flechtmann, 1975; Lindquist et al., 1996).

\subsection{O ácaro do coqueiro, Aceria guerreronis Keifer (Prostigmata: Eriophyidae)}

Nesta revisão serão abordados aspectos relacionados ao histórico, importância econômica, origem, dispersão, medidas de controle e manejo do ácaro do coqueiro, Aceria guerreronis Keifer.

\subsubsection{Histórico e importância econômica}

Aceria guerreronis é a única espécie de ácaro da superfamília Eriophyoidea considerada séria praga do coqueiro (Moore \& Howard, 1996).

Populações de A. guerreronis desenvolvem-se na região meristemática dos frutos, coberta pelo perianto. A alimentação dos ácaros nesta região aparentemente causa danos físicos de maneira que o tecido em formação danificado se expande, tornando-se visível sobre o fruto uma superfície necrótica e suberificada. O crescimento desigual resulta em distorção e atrofia do coco, levando a reduções na produção de copra. As perdas são maiores quando as infestações ocorrem no início do desenvolvimento dos frutos (Mariau, 1986). A queda prematura e acentuada de frutos também tem sido observada devido às infestações. 
Além de danos aos frutos, constatou-se no Brasil a morte de plantas devido à alimentação destes ácaros no tecido meristemático apical dos coqueiros. A alimentação dos ácaros causa clorose das folhas jovens, seguida de escurecimento dos tecidos atacados, com a formação de lesões castanho-escuras que se desenvolvem no sentido das nervuras. O crescimento é retardado e as mudas fortemente atacadas mostram-se pequenas, retorcidas e deformadas (Aquino \& Arruda, 1967). As lesões podem tomar a folha e causar a morte do broto terminal que em consequência determina a morte de toda a planta. Apesar de continuadamente procurados por especialistas, coqueiros jovens infestados por A. guerreronis estes não tem mais sido encontrados no Brasil (Arruda ${ }^{6}$; Gondim $\mathrm{Jr}^{7}$ ).

A. guerreronis foi descrita a partir de espécimes coletados no Estado de Guerrero, México, alimentando-se e danificando brácteas florais e frutos novos em desenvolvimento (Keifer, 1965). No mesmo ano em que este ácaro foi descrito, observou-se que a infestação variava de 80 a 100\% em várias regiões daquele país (Ortega et al., 1967).

Entretanto, há informação de que o ácaro do coqueiro já estivesse bastante disseminado em algumas regiões americanas mesmo antes de sua descrição original. Seus sintomas foram observados antes de 1965 em alguns países da América do Sul e, posteriormente, relacionados com este ácaro. Na Colômbia, foi relatada em 1948 a ocorrência do sintoma denominado "mancha de la nuez del cocotero" em várias regiões do litoral atlântico (Zuluaga \& Sánchez, 1971). Posteriormente, este sintoma também foi relatado por Sánchez (1962), que o chamou de "roña o escoriación de los frutos del cocotero" (Zuluaga \& Sánchez, 1971). A causa destes sintomas não foi determinada até que frutos afetados foram examinados, encontrando-se sobre eles ácaros identificados como A. guerreronis. Nesta região, observou-se uma notável diminuição do tamanho dos frutos atribuído às infestações pelos ácaros, a qual chegava a um nível de cerca de

\footnotetext{
${ }^{6}$ ARRUDA, G. P. (Instituto de Pesquisas Agropecuárias do Estado de Pernambuco). Comunicação pessoal, 2000.

${ }^{7}$ GONDIM Jr., M.G.C. (UFRPe, Universidade Federal Rural de Pernambuco). Comunicação pessoal, 2002.
} 
60\% (Zuluaga \& Sánchez, 1971). No Brasil, Robbs \& Peracchi (1965) relataram pela primeira vez a ocorrência de A. guerreronis infestando seriamente coqueirais em Santa Cruz, no Estado do Rio de Janeiro, causando "ferrugem" e queda de frutos. Estes autores citaram naquela publicação que já haviam observado sintomas deste eriofiídeo em Pernambuco, onde os danos causados ainda não eram significativos.

Em 1967, observou-se significativa queda de frutos pequenos nos coqueirais do Estado de Zulia, Venezuela, constatando-se pela primeira vez, alta infestação de $A$. guerreronis naquele país. Posteriormente, constatou-se que esta espécie encontrava-se amplamente distribuida na região do Lago de Maracaibo, no noroeste da Venezuela. De acordo com informações de agricultores de regiões próximas à Maracaibo, o problema começou a se manifestar violentamente no final de 1965 ou início de 1966. A intensidade dos danos era muito alta, estimando-se a perda dos frutos como superior a 70\%. Atribuiu-se a causa de problemas tão sérios com esta praga a fatores ecológicos (Doreste, 1968).

Um pouco mais tarde, a presença do ácaro do coqueiro foi relatada no Caribe. Em Cuba, infestações por $A$. guerreronis foram observadas pela primeira vez na região de Baracoa, onde se encontra a maior área de produção do país, no início da década de 1970 (Estrada \& Gonzalez, 1975). Verificou-se que a intensidade de infestação variava de 42 a 65\% (Suarez, 1991).

Em Trinidad, não se sabe com precisão em que ano o ácaro foi observado pela primeira vez, mas isto ocorreu um pouco antes ou depois de 1976 (Griffith, 1984); em Porto Rico, desde 1977 (Howard et al., 1990); em Santa Lucia, desde 1980 (Moore et al., 1989); em Grenada e Saint Vincent, antes de 1985 e na República Dominicana, desde 1984 (Moore, 1986).

Na Costa Rica, o primeiro relato da ocorrência de A. guerreronis foi feito por Schliesske (1985), que considerou a espécie endêmica. Observou-se que na costa Atlântica ao sul de Limon, 90\% das árvores estavam infestadas e uma porcentagem igualmente alta de frutos estava danificada.

Nos EUA, a presença de A. guerreronis foi relatada por primeira vez na Florida, em 1984 (Howard et al., 1990). Também, no final dos anos 90, mais precisamente em 
1997, constatou-se a ocorrência de A. guerreronis em plantas jovens de Syagrus romanzoffiana (Cham.) Glass., em San Diego, Califórnia, EUA (Ansaloni \& Perring, 2002).

O primeiro relato do ácaro do coqueiro na África foi feito quase que simultaneamente à sua descrição no México e aos relatos de ocorrência no Brasil, Colômbia e Venezuela.

Este eriofiídeo foi encontrado no Golfo de Guiné, em São Tomé e Príncipe, em 1966 (Cabral \& Carmona, 1969). Na África continental, A. guerreronis foi relatada pela primeira vez em Benin, em 1967, e em menos de dois anos foi constatado em todas as áreas de produção (Mariau, 1969, 1977). Posteriormente, o ácaro foi encontrado em países vizinhos - Togo, Nigéria, Camarões (Mariau, 1977; Julia \& Mariau, 1979). Na Costa do Marfim, este ácaro foi relatado pela primeira vez em 1975, em vários pontos do sudeste do país. Reduções de 7 a 15\% na produção de copra foram verificadas em distintas variedades (Julia \& Mariau, 1979). Recentemente, danos causados por A. guerreronis foram observados em Gâmbia, indicando que provavelmente esteja presente em todos os países entre Gâmbia e Nigéria (Moore \& Howard, 1996).

Supõe-se que o ácaro do coqueiro tenha sido introduzido no leste da África, especificamente na Tanzânia, no início dos anos 80, e que tenha sido proveniente do oeste africano. Atualmente, A. guerreronis encontra-se amplamente disseminada nas áreas de produção de coco da Tanzânia e em sua costa, nas Ilhas de Máfia, Zanzibar e Pemba. Em levantamentos realizados nestas áreas em 1992 e 1996, as perdas de peso seco de frutos de coco que chegaram à maturação atingiram de 20 a $30 \%$. As perdas devido à queda prematura de frutos variaram de 10 a $100 \%$, com uma média de $21 \%$ (Seguni, 2002).

Até a segunda metade da década de 1990, infestações pelo ácaro do coqueiro não haviam sido relatadas na região Indo-Pacífica, a qual é atualmente aceita como centro de origem do coqueiro e onde a cultura apresenta sua maior expressão sócio-econômica. No final de 1997, foram observadas infestações por A. guerreronis em Sri Lanka. A praga surgiu inicialmente na região conhecida como Kalpitiya, Distrito de "North Western", dispersando-se subseqüentemente para cerca de 15.000 acres nas áreas vizinhas. A 
incidência da praga variou de 5 a 100\%. A partir de então, medidas quarentenárias e controle químico foram adotados numa tentativa de conter e suprimir as infestações. Vários acaricidas/inseticidas foram avaliados, nenhum causando reduções consideráveis nas populações da praga (Fernando et al., 2000).

Na Índia, uma alta infestação de coqueiros por A. guerreronis foi constatada em 1998, no Distrito de Ernakulam, Central Kerala (Sathiamma et al., 1998). Em 1999, os resultados de levantamentos mostraram que a praga encontrava-se estabelecida em todo o estado de Kerala e também em partes de Tamil Nadu, Karnataka e Andra Pradesh, no sul da Índia. A incidência da praga também foi observada em três ilhas de Lakshadweep - Minicoy, Kalpeni e Kavaratti (Haq, 1999). Levantamentos mostraram que a incidência variou entre 20 a $70 \%$ dos frutos e que a redução de copra foi de cerca de $40 \%$ (Nair \& Koshy, 2000; Muthiah \& Bhaskaran, 2000).

Na América e África, estima-se que a diminuição na produção de copra varie de 10 a 30\% (Hernandez, 1977; Julia \& Mariau, 1979; Moore, 1986).

Até o momento, não foram relatadas infestações por $A$. guerreronis em áreas de produção de coco de outros países do sudeste asiático ou nas ilhas do Pacífico.

\subsubsection{Origem e hospedeiros de A. guerreronis}

Apesar da alta especificidade dos Eriophyoidea em geral, há evidências de que algumas espécies podem se reproduzir em espécies exóticas do mesmo gênero que seu hospedeiro original, atingindo naqueles altos níveis populacionais. Neste caso, estaria ocorrendo uma expansão da gama de hospedeiros do ácaro considerado, com a introdução de espécies botânicas exóticas (Oldfield, 1996).

Há evidências de que o coqueiro não seja o hospedeiro original de $A$. guerreronis. Assim como relatado por Oldfield (1996) para outras espécies de eriofiídeos, é possível que A guerreronis tenha como hospedeiro original alguma(s) palmeira(s) nativa(s) das Américas ou da África (continentes onde primeiramente foram relatadas infestações por este eriofiídeo) e em um período relativamente curto de tempo 
tenha adotado o coqueiro como hospedeiro, tendo sobre esta planta se disseminando pelo mundo através do transporte/intercâmbio de material vegetal.

A alta especificidade hospedeira dos ácaros Eriophyoidea reflete uma íntima relação evolutiva entre as espécies deste grupo e as plantas por eles infestadas. A sobrevivência dos eriofiídeos especialistas depende da sobrevivência de seus hospedeiros (Oldfield, 1996). Os severos danos causados por A. guerreronis ao coqueiro, isto é, a morte de plantas jovens ou a queda acentuada de frutos imaturos, são indicações de que a sua associação a este hospedeiro é relativamente recente.

Outro argumento que corrobora esta hipótese é a ausência, até há poucos anos, de A. guerreronis na região Indo-Pacífica, aceita como centro de origem do coqueiro. Isto indica que este ácaro se adaptou ao coqueiro dada a expansão desta cultura nas Américas e África (Moore \& Howard, 1996).

Atualmente três espécies de palmeiras são conhecidas como hospedeiras de $A$. guerreronis, além do coqueiro. Na América, foram constatadas infestações deste eriofiídeo, em viveiros, sobre duas espécies: Lytocaryum weddellianum (H. A. Wendland), a conhecida "palmeirinha de Petrópolis", em bainhas folhares e brotos terminais, Indaiatuba, São Paulo, Brasil (Flechtmann, 1989); e Syagrus romanzoffiana (Cham.) Glassm., o “jerivá”, em tecidos meristemáticos, San Diego, Califórnia, EUA (Ansaloni \& Perring, 2002). Poucos anos depois dos primeiros relatos de ocorrência do ácaro do coqueiro na Índia, uma outra palmeira foi relatada como hospedeira alternativa de A. guerreronis naquele país; colônias numerosas de A. guerreronis foram coletadas abaixo das brácteas dos frutos de Borassus flabellifer Linn., “palmyra”, em Tamil Nadu, India (Ramaraju \& Rabindra, 2002). Mais recentemente isto também foi observado em Sri Lanka (Moraes \& Fernando ${ }^{8}$ ).

O jerivá, S. romanzoffiana, é de grande importância como ornamental na Califórnia, onde é cultivado em viveiros e em espaços abertos para venda à população. Altas infestações em plantas importadas do México para os EUA foram constatadas por Ansaloni \& Perring (2002). Um projeto para a criação e estudos de biologia,

8 MORAES, G.J.de. (Escola Superior de Agricultura Luiz de Queiroz (ESALQ), Universidade de São Paulo) \& FERNANDO, L.C.P (Coconut Research Institute, Lunuwila, Sri Lanka) (Em elaboração). 
comportamento e controle deste eriofiídeo vem sendo desenvolvido na Universidade da Califórnia. Os danos causados às plantas jovens de $S$. romanzoffiana se assemelham aos observados por Aquino \& Arruda (1967) em coqueiros jovens no Estado de Pernambuco, Brasil.

Até o momento, não foram encontradas colônias de A. guerreronis em palmeiras presentes em áreas de vegetação nativa nas Américas ou na África, as quais poderiam ser hospedeiras originais deste eriofiídeo, nas Américas ou na África. Um maior conhecimento sobre o espectro de hospedeiros de A. guerreronis, o qual poderia ser obtido através de levantamento de ácaros eriofiídeos associados a plantas jovens ou a frutos de palmeiras, em suas áreas de ocorrência natural nas Américas e na África, auxiliariam a elucidar a questão do hospedeiro e região de origem do ácaro do coqueiro. Também seria elucidativo avaliar a variabilidade genética e morfológica entre as populações de A. guerreronis de diferentes hospedeiros.

\subsubsection{Medidas de controle e manejo de A. guerreronis}

Entre as medidas de controle que vem sendo utilizadas, avaliadas, ou que apresentem potencial para o controle e manejo do ácaro do coqueiro, destacam-se o controle químico, os inseticidas botânicos, a resistência de cultivares e o controle biológico por patógenos e predadores.

\section{Controle químico}

No México, bons resultados de controle de A. guerreronis foram obtidos utilizando-se dicrotofós, monocrotofós ou quinometionato pulverizados nas inflorescências a intervalos de 20 a 30 dias. Estes produtos reduziram significativamente os danos causados por este eriofiídeo (Hernandez, 1977).

A eficiência de diferentes acaricidas/inseticidas e de alguns produtos de origem vegetal também foi avaliada na Índia, no período de 1998-1999. Pulverizações com 
triazofós, metil demeton ou monocrotofós nos cachos de inflorescências e frutos jovens reduziram as populações quando aplicados a intervalos de 10-20 dias (Muthiah \& Bhaskaran, 1999; Ramaraju et al., 2002). Kannaiyan et al. (2002) observaram alta mortalidade do ácaro do coqueiro após pulverização com triazofós, fosalone e metil demetom aplicados mensalmente em Tamil Nadu, Índia.

Aplicações de monocrotofós e metil demetom no solo ou através de injeções no tronco em intervalos de 10-15 dias também reduziram os danos causados por $A$. guerreronis em cerca de 25\% (Muthiah \& Bhaskaran, 1999). Injeções mensais de monocrotofós ou vamidotiom nos caules também foram recomendadas por Julia \& Mariau (1979) e por Griffith (1984). Este tipo de tratamento tem sido considerado como sendo de aplicação mais fácil, mais seguro ambientalmente e possível de se usar para as variedades de coqueiros de porte alto (Muthiah \& Bhaskaran, 1999).

Os trabalhos de controle químico de A. guerreronis mostram que é possível reduzir os danos causados pelo ácaro realizando aplicações que devem ser repetidas a curtos intervalos de tempo (Muthiah \& Bhaskaran, 2000). Entretanto, considerando a natureza da cultura, o controle químico deste ácaro parece pouco viável (Moore \& Howard, 1996; Ramaraju et al., 2000). A utilização freqüente deste método de controle elevaria demasiadamente o custo de produção, poderia causar sérios problemas para o ambiente e para a utilização dos frutos in natura ou de outros produtos para alimentação (Moore \& Howard, 1996).

\section{Inseticidas botânicos}

Alguns inseticidas botânicos vêm sendo testados e recomendados para o controle de A. guerreronis no sudeste asiático, especialmente extratos de alho (Allium sativum L.) e óleo de nim (Azadirachta indica A. Juss) (Kannaiyan, 2002; Madhavan et al., 2002; Nair, 2002; Ramaraju et al., 2002). A aplicação de uma mistura destes produtos mesclada a pequenas quantidades de detergente resultou em controle do ácaro em cerca de 67\% (Nair, 2002). Inseticidas botânicos à base de óleo de nim e extratos de alho 
aplicados em intervalos de 60 dias vêm se mostrando eficientes na diminuição de populações do ácaro do coqueiro (Kannaiyan, 2002).

\section{Resistência de cultivares}

O arranjo das brácteas nos cocos influencia o padrão de ataque por $A$. guerreronis. Constatou-se que os danos são menos severos quando as brácteas são mais apertadas ao coco e quando estas não estão sobrepostas. Isto sugere que o espaço físico é importante nas infestações pelo ácaro e pode ser uma característica para seleção de cultivares mais resistentes (Moore, 1986).

Mariau (1986) relatou que cultivares variam em susceptibilidade à infestações por A. guerreronis, e que árvores de uma variedade de Cambodia não sofrem ataque pelo ácaro.

Na Tanzânia, observou-se que a maioria dos cultivares são susceptíveis à infestação por A. guerreronis, inclusive a maioria das subpopulações de "East African Tall" e variedades anãs. Entretanto, algumas das variedades introduzidas ("Polynesian Tall”, “Malayan Red Dwarf”, “Rennel Tall”, “Cameroon Red Dwarf” e “Equatorial Green Dwarf”), apresentam maior tolerância ao ataque do ácaro (Seguni, 2000).

Em Tamil Nadu, avaliou-se o dano caudado por A. guerreronis a 31 genótipos de C. nucifera e constatou-se que quatro deles (“Lakshadweep Ordinary”, “Cochin China”, “Andaman Ordinary” e “Gangabondam”) apresentaram danos mínimos, podendo ser utilizados em programas de melhoramento de variedades resistentes ao ácaro (Muthiah \& Bhaskaran, 1999). Avaliações de genótipos de C. nucifera em relação a infestações pelo ácaro do coqueiro também foram reportadas por Kannaiyan et al. (2002), que observaram diferenças significativas de danos entre os genótipos avaliados.

A introdução gradual de cultivares resistentes no manejo de A. guerreronis representa uma possibilidade promissora. Entretanto, faz-se necessária a intensificação das pesquisas, que por sua natureza demandam períodos relativamente longos de tempo. Variedades mais resistentes às infestações pelo ácaro do coqueiro poderão ser utilizadas juntamente com outros métodos de controle no manejo da praga. 


\section{Controle biológico por patógenos}

O fungo Hirsutella thompsonii (Fisher), específico para ácaros e extensivamente estudado para o controle do ácaro da falsa ferrugem em citros, tem sido isolado de amostras de A. guerreronis em áreas tropicais da América e do oeste da África e de amostras de Colomerus novahebridensis de Nova Hebrides, Nova Guiné e Sri Lanka (Hall et al., 1980; Moore \& Howard, 1996). A utilização deste fungo em campo tem tido resultados variáveis. No México, obteve-se mortalidade de mais de 75\% (Espinosa \& Carrillo, 1986), mas não se obteve sucesso no oeste da África (Anon. citado por Moore \& Howard, 1996). Em Cuba, estudos sobre a utilização de H. thompsonii para o controle do ácaro do coqueiro vem sendo realizados há mais de 20 anos e considera-se que o uso deste micoacaricida nas regiões mais úmidas de cada país, isoladamente ou em combinação com outros métodos de controle, representa uma alternativa extremamente promissora para o controle deste ácaro (Cabrera, 2002). Uma alta incidência de $H$. thompsonii e a presença de isolados altamente patogênicos a A. guerreronis também foram relatadas na Índia, após o estabelecimento da praga, sugerindo um importante papel do fungo na supressão de populações, assim como a possibilidade de sua utilização no manejo deste eriofiídeo (Kumar et al., 2001). Há grandes perspectivas para

o controle de A. guerreronis com o desenvolvimento de um micopesticida. Isto requer a intensificação da prospecção e resolução de problemas de formulação e aplicação (Moore \& Howard, 1996).

\section{Controle biológico por predadores}

De uma maneira geral, o controle biológico pode ser aplicado utilizando-se uma das três estratégias: conservação, inundação ou controle biológico clássico. As duas primeiras referem-se à utilização de inimigos naturais que já estão presentes em uma determinada região. A terceira envolve a importação, colonização e estabelecimento de inimigos naturais exóticos para controlar uma determinada praga, normalmente quando esta se refere a uma espécie introduzida em áreas onde não ocorrem inimigos naturais. 
Ácaros das famílias Ascidae, Bdellidae, Cheyletidae, Tarsonemidae e Phytoseiidae têm sido relatados predando A. guerreronis (Moraes \& Zacarias, 2000; Ramaraju et al., 2000). Entretanto, considerando dados históricos e observações de campo conduzidas na cultura de coco, parece mais promissora a utilização de ácaros fitoseídeos. Tem sido mostrado que ácaros fitoseídeos evitam exposição direta à luz solar, escondendo-se em áreas protegidas das plantas. Este fato pode ser considerado positivamente significante em relação ao controle de A. guerreronis, devido à sua preferência por locais protegidos, onde os fitoseídeos podem ter boas chances de encontrá-los e controlá-los. Por outro lado, as dimensões dos locais ocupados por $A$. guerreronis podem ser muito reduzidas para ácaros fitoseídeos, exceto espécies pequenas ou relativamente achatadas, como por exemplo algumas espécies de Neoseiulus (Moraes \& Zacarias, 2000).

Apesar de várias espécies de fitoseídeos terem sido observadas em coqueiros, inclusive algumas observadas predando A. guerreronis, este fato tem sido verificado apenas ocasionalmente e as populações dos predadores tem sido muito baixas. Até o momento, não há informação sobre o impacto destes predadores sobre as populações de A. guerreronis (Howard et al., 1990).

É necessária a realização de estudos envolvendo a colaboração de especialistas de diferentes países para prospecção de inimigos naturais de A. guerreronis, seguida de avaliação e desenvolvimento de técnicas de criação ou produção massal e manutenção dos mesmos nas áreas infestadas (Moraes, 2000).

Sendo uma praga introduzida e desejando-se a implantação de um programa de controle biológico clássico, são necessárias informações sobre a região de origem da praga para a priorização de áreas para prospecção de agentes de controle. É de se esperar que os inimigos naturais eficientes da praga encontrem-se na sua região de origem, onde a praga e os inimigos naturais tiveram contato por um longo período de tempo e onde um equilíbrio entre estes deve ter evoluído (Van Driesche \& Bellows, 1996).

No caso particular de A. guerreronis, não se dispõe de informações sobre sua região de origem e há indicações de que seu hospedeiro original não seja o coqueiro, mas sim alguma outra espécie de Arecaceae, como discutido anteriormente. Neste caso, 
os inimigos naturais eficientes para o controle deste eriofí́deo provavelmente seriam encontrados junto ao(s) hospedeiro(s) original(ais) (Moraes \& Zacarias, 2000). Daí a conveniência em se conhecer os principais hospedeiros da praga considerada e dos inimigos naturais a ela associados sobre aqueles. 


\section{3 ÁCAROS ERIOPHYOIDEA (ACARI: PROSTIGMATA) ASSOCIADOS A PALMEIRAS (ARECACEAE) EM ALGUMAS ÁREAS DAS AMÉRICAS}

\section{Resumo}

Este trabalho teve como objetivos ampliar o conhecimento sobre o espectro de hospedeiros de Aceria guerreronis Keifer e sobre a fauna de Eriophyoidea (Prostigmata) em palmeiras (Arecaceae) na América. Foi realizado um levantamento de ácaros Eriophyoidea em folíolos, brotos terminais, frutos e inflorescências de 191 espécies de palmeiras, em suas áreas de ocorrência natural ou em áreas onde foram introduzidas, em localidades dos Estados do Amazonas, Rio de Janeiro e São Paulo, Brasil; Quintana Rôo e Yucatan, México; e Limón e San José, Costa Rica, no período de janeiro de 2000 a setembro de 2003. Aceria guerreronis não foi encontrada em nenhuma das amostras analisadas, nem mesmo nas de Lytocaryum weddellianum (H. Wendl.) e Syagrus romanzoffiana (Cham.) Glassm., palmeiras sobre as quais o ácaro havia sido relatado

previamente por outros autores. Foram coletadas 38 espécies de Eriophyoidea pertencentes a 14 gêneros, em 34 espécies de palmeiras. Vinte e seis das espécies e três dos gêneros de Eriophyoidea eram novos táxons. Foram relatados 18 novos hospedeiros para seis espécies coletadas e novas localidades de ocorrência para duas espécies.

\section{ERIOPHYOIDEA MITES (ACARI: PROSTIGMATA) ASSOCIATED WITH PALM TREES (ARECACEAE) IN SOME AREAS OF THE AMERICAS}

\section{Summary}


The objectives of this work were to evaluate the host range of Aceria guerreronis Keifer and to determine the Eriophyoidea fauna on palm trees in points of the American continent. A survey of those mites on leaflets, terminal shoots, fruits and inflorescences of 191 species of palm trees was conducted in areas of natural occurrence or where they had been introduced, in sites of the States of Amazonas, Rio de Janeiro and São Paulo, Brazil, Quintana Rôo and Yucatan, Mexico, and Limón and San José, Costa Rica, between January 2000 and September 2003. Aceria guerreronis was not found on any of the samples, including Lytocaryum weddellianum (H. Wendl.) and Syagrus romanzoffiana (Cham.) Glassm., on which the mite had been reported by other authors. Thirty-eight species of Eriophyoidea belonging to 14 genera were found on 34 palm tree species. Twenty-six species and three genera of Eriophyoidea were new taxa. Eighteen new host species for six mite species and new sites of occurrence for two mite species were determined.

\subsection{Introdução}

A maioria dos Eriophyoidea é extremamente específica em relação à planta hospedeira, sendo cada espécie relatada sobre um único hospedeiro ou limitando-se a hospedeiros de um mesmo gênero. Entretanto, há evidências de que algumas espécies infestam plantas exóticas do mesmo gênero ou de gêneros próximos ao de seu hospedeiro original (Oldfield, 1996).

Do ponto de vista econômico, o principal hospedeiro de Aceria guerreronis Keifer, na maioria das suas áreas de ocorrência, é o coqueiro, Cocos nucifera L.. Contudo, há indicações de que este não seja seu hospedeiro original (Moore \& Howard, 1996; capítulo 2). A ausência de A. guerreronis na região Indo-Pacífica, possível região de origem do coqueiro, até 1997 (Fernando et al., 2000) é um dos fatores que indicam que este ácaro expandiu seu espectro de hospedeiros, movendo-se de uma palmeira desconhecida para o coqueiro, dada a expansão da distribuição deste nas Américas e na África. A alta especificidade hospedeira dos ácaros eriofiídeos reflete uma íntima 
relação evolutiva entre estes ácaros e as plantas. A sobrevivência dos eriofí́deos depende da sobrevivência de seus hospedeiros (Oldfield, 1996). Os severos danos causados por A. guerreronis ao coqueiro, isto é, a morte de plantas jovens, danos e queda prematura de frutos (órgãos reprodutivos), são uma outra indicação de sua associação recente a este hospedeiro.

O ácaro do coqueiro, A. guerreronis, é uma praga que tem se disseminado e atualmente encontra-se estabelecida nas principais áreas de produção de coco nas Américas e na África e, recentemente, no sudeste asiático. Agentes de controle biológico podem vir a ser utilizados para o manejo deste ácaro e esforços vem sendo empregados neste sentido. O conhecimento do hospedeiro original e da região de origem de $A$. guerreronis é importante para a implementação de um programa de controle biológico clássico, que envolve a busca de inimigos naturais eficientes da praga em outros locais para a introdução em uma nova região onde se pretende controlar a praga. Normalmente, os inimigos naturais eficientes são encontrados na região de origem de uma espécie.

Há uma grande diversidade de palmeiras (Arecaceae) nas regiões tropicais, mas pouco se conhece sobre os ácaros Eriophyoidea associados a este grupo de plantas, especialmente na região Neotropical. Ocorrem nas Américas cerca de 550 espécies de palmeiras (Henderson et al., 1995) e, até o momento, foram relatados ácaros desta família sobre apenas 24 destas espécies (Amrine \& de Lillo, 2003; Capítulo 5).

Levantamentos de ácaros eriofiídeos associados a palmeiras poderão trazer maiores informações sobre a amplitude de hospedeiros de A. guerreronis e, talvez, sobre seu hospedeiro original. Observa-se a necessidade de direcionar maiores esforços para ampliar o conhecimento sobre os Eriophyoidea associados às palmeiras, especialmente nas regiões tropicais da América e África, continentes onde este ácaro foi primeiramente relatado.

Nas Américas, além de C. nucifera, A. guerreronis também foi encontrada infestando duas palmeiras ornamentais nativas do Brasil, a palmeirinha-de-Petrópolis, Lytocaryum weddellianum (H. A. Wendland), e o jerivá, Syagrus romanzoffiana (Cham.) Glassm.. Ambas espécies foram encontradas infestadas por A. guerreronis em viveiros, em localidades afastadas de suas áreas de ocorrência natural (Flechtmann, 
1989; Ansaloni \& Perring, 2002). Aceria guerreronis ainda não foi encontrada associada a estas palmeiras em suas áreas de ocorrência natural no Brasil, apesar de que alguns levantamentos de ácaros Eriophyoidea associados a palmeiras no Brasil venham sendo realizados nos últimos anos (Flechtmann, 1994b, 1997, 1998; Flechtmann \& Santana, 1997; Gondim Jr., 2000; Santana et al., 1994; Santana \& Flechtmann, 1998).

É possível que A. guerreronis apresente outros hospedeiros na família Arecaceae, em áreas de preservação natural, ou onde as palmeiras são cultivadas. Este trabalho teve como objetivo principal detectar outros hospedeiros de A. guerreronis, através do levantamento de ácaros da superfamília Eriophyoidea associados a palmeiras em suas áreas de ocorrência natural e/ou em áreas em que as mesmas foram introduzidas e/ou são cultivadas.

Este levantamento contribui também para ampliar o conhecimento sobre os ácaros Eriophyoidea associados às palmeiras nas Américas. Um considerável aumento da área plantada com culturas da família Arecaceae tem ocorrido no centro-sul do Brasil, especialmente de coco, C. nucifera; palmito doce, Euterpe edulis Mart. e pupunha, Bactris gasipaes Kunth. O conhecimento da acarofauna associada a esta família de plantas pode fornecer subsídios ao reconhecimento futuro destes ácaros em cultivos comerciais de arecáceas e, desta forma, facilitar o entendimento das possíveis alterações dos agroecossistemas que possam tê-los, eventualmente, tornado novas pragas.

\subsection{Revisão de Literatura}

Nesta revisão foram abordados aspectos sobre a especificidade hospedeira dos ácaros Eriophyoidea e o espectro de hospedeiros de A. guerreronis e, também, reunidas informações sobre os ácaros Eriophyoidea encontrados sobre palmeiras no Brasil, México e Costa Rica. 


\subsubsection{Eriophyoidea, especificidade hospedeira}

A grande especificidade em relação à planta hospedeira exibida pela maioria dos Eriophyoidea reflete uma íntima relação ácaro-planta. A maioria das espécies é reportada sobre um único hospedeiro e algumas são limitadas a espécies de um único gênero. Algumas poucas espécies podem se reproduzir em membros de mais de uma família (Oldfield, 1996).

Alguns Eriophyoidea associados a monocotiledôneas são relatados infestando um grande número de hospedeiros de gêneros distintos. Tem sido constatado também que algumas espécies de Eriophyoidea relatadas infestando hospedeiros em diversas famílias de monocotiledôneas representavam um complexo de espécies, ao invés de uma única espécie biológica (Oldfield, 1996).

Há evidências de que algumas espécies relatadas de um hospedeiro possam se desenvolver bem sobre espécies exóticas do mesmo gênero que seu hospedeiro original. Epitrimerus pungiscus Keifer, que ocorre em baixos níveis populacionais em Picea abies (L.) em condições naturais na Finlândia, atinge altos níveis populacionais em viveiros desta espécie e de diversos membros exóticos de Picea naquele país (Loyttyniemi, $1975^{1}$ em Oldfield, 1996). Eriophyes insidiosus Keifer \& Wilson , que ocorre no sudoeste dos EUA e no México em diversas espécies nativas de ameixas, infestam pomares de pêssego introduzidos naquela região. Aculops lycopersici (Tryon, 1917) ocorre em vários hospedeiros na família Solanaceae, mas danos severos são comumente causados somente ao tomateiro (Perring, 1996). Estes exemplos tratam de espécies de Eriophyoidea que provavelmente ampliaram seu espectro de hospedeiro com a introdução de espécies exóticas relacionadas às espécies de plantas que usualmente atacam.

${ }^{1}$ LOYTTYNIEMI, K. Mass outbreaks of Epitrimerus pungiscus Keifer (Acarina, Eriophyidae) on Norway spruce, Picea abies (L.). Karst. Ann. Entomol. Fenn, v.41, p.13-15, 1975. 


\subsubsection{Espectro de hospedeiros de $A$. guerreronis}

O coqueiro, C. nucifera, constituia o único hospedeiro conhecido de A. guerreronis até que Flechtmann (1989) relatou pela primeira vez a ocorrência deste ácaro em outra espécie de Arecaceae, a palmeirinha-de-Petrópolis, L. weddellianum. Plantas jovens, provenientes de viveiros de Indaiatuba, SP, apresentando sintomas de infestação por nematóides, foram encaminhadas ao Departamento de Zoologia, ESALQ, USP, Piracicaba, SP. Nesta ocasião verificou-se que, na verdade, as plantas encontravam-se livres de nematóides, mas infestadas por ácaros eriofiídeos que formavam colônias numerosas nos brotos terminais. Estes ácaros foram identificados como A. guerreronis.

Um terceiro hospedeiro para A. guerreronis foi relatado em 1997, quando diversos viveiros do sul da California, EUA, apresentaram sérios problemas de clorose de meristema e morte de plantas jovens de jerivá, S. romanzoffiana,. Constatou-se que os danos eram causados pelas infestações por ácaros eriofiídeos, identificados como $A$. guerreronis. Estudos sobre a biologia e comportamento do ácaro do coqueiro sobre este novo hospedeiro vem sendo realizados na Universidade da California, Riverside, EUA (Ansaloni \& Perring, 2002).

Poucos anos após o primeiro relato do ácaro do coqueiro na India, em 1998 (Sathiamma et al., 1998), verificou-se que uma palmeira nativa e abundante, conhecida como "palmyra", Borassus flabellifer L., hospedava este ácaro. Frutos de "palmyra" coletados na região de Coimbatore, Tamil Nadu, India, apresentavam colônias numerosas de A. guerreronis, sob as tépalas, como nos frutos de coco (Ramaraju \& Rabindra, 2001). Também em junho de 2003, nas proximidades de Kalpityia, Sri Lanka, foram coletados frutos de "palmyra" infestados por A. guerreronis (Moraes \& Fernando ${ }^{2}$ ).

2 MORAES, G.J.de. (Escola Superior de Agricultura Luiz de Queiroz (ESALQ), Universidade de São Paulo) \& FERNANDO, L.C.P (Coconut Research Institute, Lunuwila, Sri Lanka) (Em elaboração). 
Desta forma, A. guerreronis foi relatada infestando três espécies de palmeiras além do coqueiro. Observa-se que A. guerreronis infesta principalmente frutos e brotos terminais das palmeiras relatadas como suas hospedeiras.

\subsection{3 Ácaros Eriophyoidea associados a palmeiras no Brasil, Costa Rica e México}

Até o início deste levantamento haviam sido relatadas 13 espécies de Eriophyoidea em 16 espécies de palmeiras no Brasil. Considerando o grande número de espécies de palmeiras no Brasil e a importância econômica das mesmas (Lorenzi, 1996), observa-se que há uma carência de trabalhos exploratórios da fauna de eriofiídeos associados a este grupo de plantas. Este mesmo cenário é observado em outros países da América, onde num total foram reportadas apenas 21 espécies de Eriophyoidea associadas a palmeiras (Amrine \& de Lillo, 2003; capítulo 5).

A. guerreronis foi o primeiro eriofiídeo reportado em palmeiras no Brasil, no Estado do Rio de Janeiro (Robbs \& Peracchi, 1965). Após quase vinte anos, Flechtmann (1994b) descreveu um novo gênero de Eriophyidae, a partir de espécimes coletados em folhas de coqueiros no Estado de São Paulo. Este novo gênero foi nomeado Amrineus Flechtmann e a espécie tipo, Amrineus cocofolius Flechtmann. Esta espécie foi redescrita em Flechtmann (1997), com base em um maior número de indivíduos coletados em diferentes localidades do mesmo Estado. Poucos anos depois, a presença de A. cocofolius foi relatado em Sergipe, Pernambuco e Bahia (Santana \& Flechtmann, 1998).

Santana et al. (1994) relataram a presença de Retracrus johnstoni Keifer no Brasil, associado a S. romanzoffiana no Estado do Rio de Janeiro. Santana \& Flechtmann (1998) reportaram a ocorrência desta espécie também na Bahia, Ceará, Paraíba, Pernambuco e Sergipe. Estes mesmos autores citaram a presença de espécimes com características morfológicas intermediárias a R. johnstoni e Retracrus elaeis Keifer associados a Euterpe oleracea Mart e apontaram a necessidade da realização de estudos taxonômicos mais detalhados sobre estas duas espécies que compõem o gênero Retracrus Keifer. 
Em seguida, duas espécies de Notostrix Keifer, já encontradas em arecáceas em outros países, foram reportadas no Brasil: Notostrix attenuata Keifer, associada a C. nucifera e S. romanzoffiana no Estado de Sergipe (Flechtmann \& Santana, 1997) e Notostrix jamaicae Keifer, associada a S. romanzofianna e a Attalea sp. no Distrito Federal (Santana \& Flechtmann, 1998).

Duas novas espécies de Eriophyoidea associadas a palmeiras nativas do Brasil foram descritas por Flechtmann (1998): Notostrix exigua Flechtmann (Eriophyidae), sobre folhas de E. edulis, e Rhynacus palmeus Flechtmann (Diptilomiopidae), sobre folhas de S. romanzoffiana, ambas coletadas no Estado do Rio de Janeiro.

Gondim Jr. (2000) realizou levantamentos de Eriophyoidea associados a 13 espécies de palmeiras exóticas e nativas nos Estados de São Paulo e Pernambuco. Este autor relatou pela primeira vez no Brasil a presença de duas espécies de Phytoptidae pertencentes ao gênero Propilus Keifer em áreas de Mata Atlântica de São Paulo: P. gentyi Keifer, associado a Astrocaryum aculeatissimum (Schott) Burret, e P. spinosus Keifer, associado a Bactris setosa Mart. e S. romanzoffiana. Quatro novas espécies foram coletadas descritas em Gondim Jr., Flechtmann \& Moraes (2000): Notostrix butiae Gondim Jr., Flechtmann \& Moraes, de Butia eriospatha (Mart. ex Drude); Notostrix nasutiformes Gondim Jr., Flechtmann \& Moraes, de C. nucifera; Knorella geonomae Gondim Jr., Flechtmann \& Moraes, de Geonoma schottiana Mart. e Propilus syagris Gondim Jr., Flechtmann \& Moraes, de S. romanzoffiana. Também foram relatados novos hospedeiros para três Eriophyoidea: Acrocomia aculeata (Jacq.) Lodd. e S. romanzoffiana para N. attenuata; A. aculeatissimum, B. setosa, Elaeis guineensis N. J. Jacquin, E. edulis; Geonoma gamiovora Barb. Rodr.; Geonoma pohliana Mart. e G. schottiana para R. johnstoni; e E. edulis para R. palmeus.

Até o momento foram relatadas, no México, duas espécies de Eriophyoidea associadas a palmeiras: A. guerreronis, descrita a partir de espécimes de Guerrero por Keifer (1965) e, posteriormente, encontrada também em Chiapas, Colima, Nayarit, Oaxaca, Sinaloa e Veracruz (Hernández Roque, 1977); e R. johnstoni, associado a Chamaedorea sp. em Chiapas e Tuxtla (Keifer, 1965b). 
Na Costa Rica, A. guerreronis, N. jamaicae e R. elaeis foram coletados em coqueiros e R. johnstoni em Chamaedorea elegans Mart. (Schiliesske, 1988). Altos níveis populacionais de R. elaeis em E. guineensis foram observados em Quepos, Costa Rica. Estes ácaros foram observados na base das folhas mais baixas e medianas (Ochoa et al., 1994).

\subsection{Material e Métodos}

As atividades deste trabalho foram realizadas em três etapas: prospecção de campo; inspeção e preservação dos ácaros Eriophyoidea; e identificação dos ácaros.

Foram identificados ácaros Eriophyoidea coletados em folíolos, broto terminal, frutos e inflorescências de palmeiras em áreas do Brasil (São Paulo, Rio de Janeiro, Amazonas), Costa Rica e México. Nos levantamentos realizados no Brasil, foram priorizadas coletas de amostras de jerivá e da palmeirinha-de-Petrópolis em áreas de ocorrência natural destas palmeiras.

Na busca de novos hospedeiros para A. guerreronis no Brasil, realizou-se coleta de amostras de palmeiras exóticas e nativas em áreas do Estado de São Paulo e de palmeiras nativas nos Estados do Rio de Janeiro e Amazonas. No México, foram coletadas amostras de palmeiras nativas em Yucatan e Quintana Roo, ambos estados localizados na Península de Yucatan.

Simultaneamente ao levantamento dos ácaros Eriophyoidea em diferentes partes de palmeiras diversas, descrito neste capítulo, realizou-se um levantamento da acarofauna, em frutos de coco, nos diversos estados brasileiros e na península de Yucatán, México. Os resultados deste último levantamento são relatados no Capítulo 9.

Não foram consideradas, na apresentação dos resultados, as coletas em que apenas um indivíduo de uma determinada espécie de Eriophyoidea foi encontrado sobre uma dada espécie de palmeira, pois a ocorrência deste poderia ser apenas ocasional, durante o processo de dispersão pelo vento. 
Além da identificação dos Eriophyoidea obtidos através da prospecção de campo no Brasil e no México, foram identificados Eriophyoidea de espécies exóticas e nativas de palmeiras de Costa Rica, enviadas pelo Dr. Hugo Aguilar, Universidade de Costa Rica, San José, Costa Rica.

\subsubsection{Prospecção de campo}

As amostras de palmeiras exóticas (de outras regiões brasileiras ou outros países) foram obtidas principalmente na Coleção de Palmeiras do Instituto Agronômico de Campinas (IAC), na Fazenda Santa Elisa e na sede do próprio Instituto, em CampinasSP; e no Parque da Escola Superior de Agricultura Luiz de Queiroz, Universidade de São Paulo, Piracicaba-SP.

Considerando a especificidade hospedeira dos ácaros eriofiídeos, o passo inicial para a busca de novos hospedeiros de um ácaro desta família é a prospecção nas demais espécies de plantas dos gêneros em que sua ocorrência já foi relatada. O coqueiro é atualmente a única espécie do gênero Cocos, portanto, não há outras espécies deste gênero em que se possa buscar A. guerreronis. Neste levantamento foram priorizadas coletas de amostras de palmeiras dos gêneros Lytocaryum Tol. e Syagrus Mart. pois A. guerreronis foi relatada infestando palmeiras destes gêneros. Lytocaryum é um gênero bastante próximo à Syagrus, composto atualmente por apenas duas espécies ( $L$. weddellianum e Lytocaryum hoehnei (Burret) Tol.) (Henderson et al., 1995), as quais tem sido constatadas apenas nas Regiões Sudeste e Sul do Brasil. A primeira é mais freqüente nas encostas montanhosas do Rio de Janeiro e Espírito Santo e a segunda, em áreas de florestas de altitude nas proximidades da cidade de São Paulo, SP (Henderson et al., 1995; Lorenzi et al., 1996). Amostras de L. weddellianum foram tomadas na Reserva Estadual de Paraíso, na Serra dos Órgãos, Teresópolis, RJ e de L. hoehnei, na Reserva Florestal do Morro Grande, Cotia, SP. O gênero Syagrus apresenta ampla distribuição na América do Sul, sendo especialmente abundante em áreas secas do centro e leste do Brasil (Henderson et al., 1995). Foram tomadas amostras de espécies de Syagrus, incluindo S. romanzoffiana, em áreas dos Estados de São Paulo e Rio de Janeiro. 
Com o propósito de confirmar a ocorrência de A. guerreronis em plantas jovens de $L$. weddellianum, em viveiros de Indaiatuba-SP, região de onde provieram as plantas desta espécie, nas quais Flechtmann (1989) relatou a ocorrência destes ácaros, foram realizadas coletas em viveiros que dispunham de plantas jovens de $L$. weddellianum naquela região.

Foram eleitas áreas de preservação com distintos tipos de vegetação no Estado de São Paulo: Cerrado, em São Carlos e Pirassununga; áreas de Mata Atlântica de baixas altitudes, em Pariquera-Açu e Cananéia; e florestas de altitude de Mata Atlântica, em Jundiaí, São Paulo. Nos locais escolhidos, foi realizada uma coleta na época fria e seca e outra na época quente e chuvosa do ano.

Foram coletadas amostras de folíolos e, sempre que possível, amostras de brotos terminais, inflorescências e frutos. Nas áreas em que era encontrada uma maior densidade populacional das palmeiras, foram coletadas amostras de pelo menos três indivíduos de cada espécie. Foram coletados cerca de 15 folíolos de folhas jovens e 15 de folhas maduras das palmeiras amostradas.

Para a coleta de amostras de palmeiras de porte alto utilizou-se um podão com cabo de até $7 \mathrm{~m}$ de comprimento, ou um auxiliar de campo escalava os troncos e, também com o auxílio do podão, retirava as amostras.

As amostras de folhas foram acondicionadas em sacos de papel, os quais eram colocados no interior de sacos plásticos. As amostras foram transportadas em caixas de poliestireno contendo bolsas térmicas, para melhor refrigeração e preservação das mesmas. No laboratório, os sacos contendo as amostras foram umedecidos e mantidos em refrigerador a $10^{\circ} \mathrm{C}$, até a inspeção.

Amostras de frutos, inflorescências e brotos terminais das palmeiras foram coletadas e, imediatamente, preservadas em potes plásticos contendo álcool etílico 70\%. Posteriormente, as amostras foram processadas no laboratório para a extração dos ácaros. Os ácaros que não pertenciam à superfamília Eriophyoidea não foram considerados neste estudo.

A identificação das palmeiras foi realizada consultando-se exicatas do herbário do Museu de Botânica, ESALQ-USP; com a colaboração do Prof. Dr. Ricardo Ribeiro 
Rodrigues, Departamento de Botânica, ESALQ-USP; ou consultando bibliografia específica para as áreas de preservação em que as palmeiras já haviam sido levantadas e identificadas.

Os locais onde foram coletadas as amostras de palmeiras, com suas respectivas coordenadas geográficas, e as datas em que as coletas foram realizadas estão especificados a seguir.

\section{Instituto Agronômico de Campinas (IAC) - Faz. Santa Elisa e Sede, Campinas-SP}

A coleção de palmeiras exóticas e nativas do Instituto Agronômico de Campinas

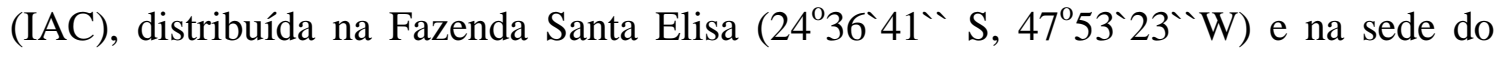
IAC, em Campinas-SP, é composta por representantes de mais de 150 espécies. A maioria das espécies da coleção encontra-se identificada até o nível específico, mas algumas estão identificadas apenas até gênero.

Foram realizadas oito coletas na Fazenda Santa Elisa e uma na Sede do IAC. Durante cada visita à coleção, foram coletadas amostras de cerca de 20 espécies distintas. As coletas foram realizadas no período de março a setembro de 2000. Foram amostradas 143 espécies de palmeiras, exóticas e nativas.

\section{Parque da Escola Superior de Agricultura “Luiz de Queiroz” (ESALQ), USP, Piracicaba-SP}

No parque da ESALQ-USP (22 $\left.42^{` 3} 0^{`} \mathrm{~S}, \quad 47^{\circ} 38^{`} 00^{`} \mathrm{~W}\right)$, Piracicaba-SP, encontram-se 55 espécies de palmeiras, exóticas ou nativas, mapeadas e, quase todas, identificadas até espécie (ESALQ, 1996). Foram coletadas amostras destas palmeiras no período de setembro a novembro de 2000. 


\section{Áreas de Cerrado do Estado de São Paulo}

Foram realizadas coletas de amostras de seis espécies de palmeiras nativas em três áreas de preservação de vegetação de Ccerrado do Estado de São Paulo: Fazenda

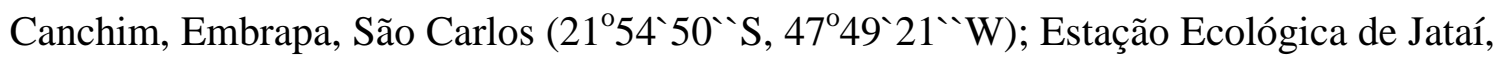
Luiz Antônio (21 $\left.31^{\circ} 33^{`} \mathrm{~S}, 47^{\circ} 47^{`} 17^{\prime} \mathrm{W}\right)$, e Faculdade de Zootecnia e Engenharia de

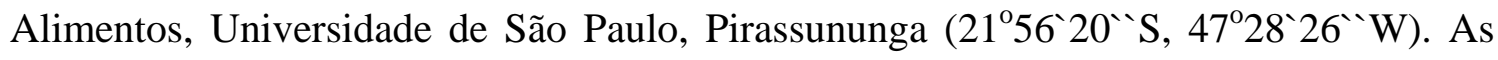
coletas foram realizadas no período de julho (frio e seco) a dezembro (quente e úmido). Em maio e julho de 2001 realizaram-se coletas adicionais de Butia archeri (Glass.) Glass. em Pirassununga e de Geonoma sp. em São Carlos.

\section{Áreas de Florestas de Altitude do Estado de São Paulo}

Foram coletadas amostras de seis espécies de palmeiras nativas em duas áreas de preservação de florestas de altitude no Estado de São Paulo: Reserva Estadual da Serra do Japi, Jundiaí (23ำ13 $\left.18^{`} \mathrm{~S}, 46^{\circ} 55^{`} 16^{`} \mathrm{~W}\right)$ e Reserva Florestal do Morro Grande, Cotia $\left(23^{\circ} 43^{`} \mathrm{~S}, 46^{\circ} 51^{`} \mathrm{~W}\right)$. As coletas foram realizadas nos meses de setembro (seco) e janeiro (úmido).

\section{Áreas de Encostas Montanhosas de Mata Atlântica no Estado do Rio de Janeiro}

Realizou-se uma coleta de amostras de oito espécies de palmeiras nativas em áreas de encostas montanhosas de Mata Atlântica na Reserva Estadual de Paraíso, Teresópolis ( $\left.22^{\circ} 29^{`} 23^{`} \mathrm{~S}, 42^{\circ} 544^{`} 7^{`} \mathrm{~W}\right)$, no período de 28 a 29 de março de 2001.

\section{Áreas de Mata Atlântica Litorâneas no Estado de São Paulo}

Foram realizadas coletas de amostras de dez espécies de palmeiras nativas em duas áreas de Mata Atlântica do Estado de São Paulo: Estação Experimental do Instituto

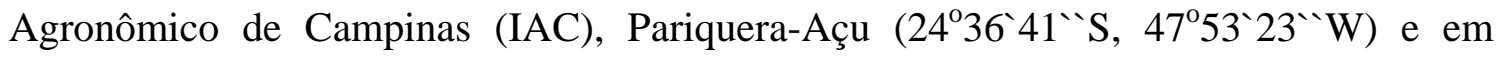


Cananéia $\left(24^{\circ} 53^{`} 45^{`} \mathrm{~S}, 47^{\circ} 50^{`} 17^{`} \mathrm{~W}\right)$. Foram realizadas quatro coletas ao longo de 2000.

\section{Áreas de Mata Atlântica na região de Piracicaba, Estado de São Paulo}

Foram amostradas cinco espécies de palmeiras nativas em três áreas de Mata Atlântica na região de Piracicaba, Estado de São Paulo: Estação Ecológica de Ibicatu

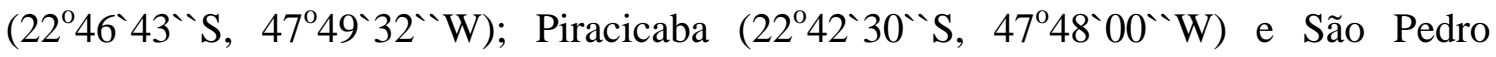
$\left(22^{\circ} 38 ` 58^{`} \mathrm{~S}, 47^{\circ} 48^{`} 31^{`} \mathrm{~W}\right)$. Foram realizadas três coletas ao longo de 2000.

\section{Península de Yucatan, México}

Foram coletadas amostras de 12 espécies de palmeiras, todas nativas, exceto o coqueiro, na península de Yucatan: Universidad de Quintana Roo e Oxtankah, Chetumal, em Quintana Roo (18 30,4 N, 88¹9,7 W); ruínas de Chichen Itzá, Yucatan (2040’00” N; 88³6’00”); ruínas de Tulum, Yucatan (20¹2’00” N; 88³6’00”) e em Celestún, Progreso (2051’39’' N; 90²3’57’’W) em Yucatan. As coletas foram realizadas no mês de setembro de 2002.

\section{Áreas de Floresta Tropical Úmida, Amazônia Ocidental, Amazonas}

Foram amostradas 13 espécies de palmeiras nativas e exóticas (C. nucifera e E. guineensis), em duas áreas da região de Manaus, AM: Embrapa Amazônia Ocidental (304’S; 59 55’W); Reserva Adolpho Ducke, Instituto Nacional de Pesquisas da

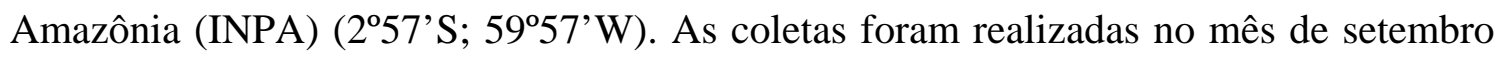
de 2003. 


\subsubsection{Inspeção acarológica e preservação dos ácaros Eriophyoidea}

As amostras foram inspecionadas no laboratório, ao microscópio estereoscópico (30x). As superfícies inferiores e superiores dos folíolos foram inspecionadas observando-se com maior atenção as regiões próximas às nervuras, onde freqüentemente os ácaros Eriophyoidease alojam. Os frutos foram inspecionados externamente, dando-se maior atenção à região sob as brácteas (quando presentes), as quais foram cuidadosamente retiradas.

O processamento das amostras de frutos, inflorescências e brotos terminais das palmeiras, preservadas em potes plásticos contendo álcool etílico 70\%, foi realizado de acordo com as seguintes as etapas de: 1) agitação dos potes; 2) peneiramento do conteúdo dos potes através de um conjunto de três peneiras metálicas com telas de malha gradualmente mais finas (60, 100, 200 mesh) ; 3) lavagem da última peneira, de tela com menor abertura (60 $\mu \mathrm{m}$ ), com o auxílio de uma piceta contendo álcool 70\% e versão do material retido para um frasco de vidro, onde os ácaros foram preservados até a montagem.

Os ácaros eriofiídeos encontrados foram coletados manualmente, com um estilete de ponta fina ou com um pincel de cerdas finas, sob estereoscópio (aumento de 40x) e montados em lâminas para microscopia, em meio de Berlese modificado (Amrine \& Manson, 1996).

\subsubsection{Identificação dos ácaros Eriophyoidea associados às palmeiras}

Os ácaros Eriophyoidea encontrados nas amostras de palmeiras foram identificados ao nível de espécie/gênero, utilizando-se microscópio de contraste de fase. A maioria dos ácaros coletados, incluindo todos os holótipos e parte dos parátipos, foram depositados na Coleção Acarológica do Setor de Zoologia, Departamento de Entomologia, Fitopatologia e Zoologia Agrícola da ESALQ-USP, Piracicaba, SP. Parátipos de espécies novas coletadas na Reserva Adolpho Ducke, INPA, Manaus, AM serão depositados na coleção do INPA, Manaus, AM. Parátipos das demais espécies 
novas também serão depositados no Smithsoniam Institution, National Museum of Natural History, Washington, DC, EUA.

Além dos ácaros coletados durante os levantamentos realizados, também foram identificadas amostras de eriofiídeos associados a espécies de palmeiras exóticas e nativas (B. gasipaes, E. guineensis e Chamaedorea costaricana Oerst.) provenientes da Costa Rica, coletados por H. Albertazzi e H. Aguilar.

A identificação dos ácaros eriofiídeos foi realizada com a colaboração do Prof. Dr. Carlos H. W. Flechtmann, pesquisador CNPq, Departamento de Entomologia, Fitopatologia e Zoologia Agrícola, ESALQ-USP.

\subsection{Resultados e Discussão}

O resultado do levantamento realizado, incluindo as espécies de palmeiras amostradas, localidades, datas das coletas, espécies de Eriophyoidea encontradas e parte da planta de onde foram coletados são indicados na Tabela 1. A ausência da citação de espécies de Eriophyoidea para uma dada amostra na Tabela 1 significa que não foram encontrados Eriophyoidea naquela amostra.

O ácaro do coqueiro, A. guerreronis, foi encontrado infestando frutos de coco nas regiões litorâneas de São Paulo e Rio de Janeiro e na Península de Yucatán, México. 
Tabela 1. Eriophyoidea associados a palmeiras em diferentes localidades do Brasil, Costa Rica e México. Espécies de palmeiras e partes das plantas amostradas, mês de coleta, localidade e espécies de ácaros encontradas. (FOL- folíolos; BTbroto terminal; FRU- frutos; INFL- inflorescências; BR- Brasil; Mx- México; CR- Costa Rica) (* novos táxons; + novo hospedeiro; $\square$ nova localidade (país ou estado))

\begin{tabular}{|c|c|c|c|c|}
\hline Palmeira & Parte da Planta & Mês de Coleta & Localidade & Eriophyoidea \\
\hline Acanthorrhiza sp. & FOL & VI.2000 & Campinas, SP, BR & \\
\hline \multirow[t]{3}{*}{ Acoelorraphe wrightii } & FOL, BT & X.2000 & Piracicaba, SP, BR & \\
\hline & FOL & IX.2002 & Chetumal,QRoo, MX & \\
\hline & FOL & VII.2000 & Campinas, SP, BR & \\
\hline \multirow[t]{5}{*}{ Acrocomia aculeata } & FOL, FRU & XI.2000 & Piracicaba, SP, BR & \\
\hline & FOL, FRU & VII; XII. 2000 & Pirassununga, SP, BR & \\
\hline & $\mathrm{FOL}^{2} \mathrm{BT}^{12}, \mathrm{INFL}$ & II: V; XI ${ }^{12} \cdot 2000$ & Ibicatu, Piracicaba, SP, BR & ${ }^{1}$ Aceria biornata* \\
\hline & & & & ${ }^{2}$ Notostrix sp.1 * \\
\hline & FOL & IX.2002 & Chetumal, QRoo, MX & \\
\hline Acrocomia sp. & FOL, FRU & VI.2000 & Campinas, SP, BR & \\
\hline Aiphanes aculeata & FOL, BT & XI.2000 & Piracicaba, SP, BR & \\
\hline Aiphanes minima & FOL & VI; X.2000 & Campinas, SP, BR & \\
\hline Aiphanes sp. & FOL & VI.2000 & Campinas, SP, BR & \\
\hline \multirow[t]{2}{*}{ Archontophoenix alexandrae } & FOL, BT & XI.2000 & Piracicaba, SP, BR & \\
\hline & FOL & VI.2000 & Campinas, SP, BR & \\
\hline \multirow[t]{2}{*}{ Archontophoenix cunninghamii } & FOL & IX.2000 & Campinas, SP, BR & \\
\hline & FOL, FRU, BT & XI.2000 & Piracicaba, SP, BR & \\
\hline Areca sp. & FOL, FRU & IX.2000 & Campinas, SP, BR & \\
\hline \multirow[t]{2}{*}{ Areca triandra } & FOL & VI.2000 & Campinas, SP, BR & \\
\hline & FOL, FRU & X.2000 & Piracicaba, SP, BR & \\
\hline Arenga australasica & FOL & VI.2000 & Campinas, SP, BR & \\
\hline Arenga caudata & FOL & VIII.2000 & Campinas, SP, BR & \\
\hline Arenga engleri & FOL & X.2000 & Piracicaba, SP, BR & \\
\hline Arenga pinnata & FOL & VII. 2000 & Campinas, SP, BR & \\
\hline Arenga sp. & FOL, FRU & VII. 2000 & Campinas, SP, BR & \\
\hline
\end{tabular}


Tabela 1. Eriophyoidea associados a palmeiras em diferentes localidades do Brasil, Costa Rica e México. Espécies de palmeiras e partes das plantas amostradas, mês de coleta, localidade e espécies de ácaros encontradas. (FOL- folíolos; BTbroto terminal; FRU- frutos; INFL- inflorescências; BR- Brasil; Mx- México; CR- Costa Rica) (* novos táxons; + novo hospedeiro; $\square$ nova localidade (país ou estado))

\begin{tabular}{|c|c|c|c|c|}
\hline Palmeira & Parte da Planta & Mês de Coleta & Localidade & Eriophyoidea \\
\hline Arenga tremula & FOL & IV.2000 & Campinas, SP, BR & \\
\hline Astrocaryum acaule & FOL & IX.2003 & Manaus, AM, BR & Palmiphytoptus sp.1* \\
\hline \multirow[t]{4}{*}{ Astrocaryum aculeatissimum } & FOL, $\mathrm{BT}^{1}$ & $\begin{array}{l}\text { I }^{1} ; \mathrm{III} ; \mathrm{IV} ; \mathrm{X}^{1} \text {. } \\
2000\end{array}$ & Cananéia, SP, BR & ${ }^{1}$ Propilus syagris \\
\hline & FOL & X.2000 & Piracicaba, SP, BR & \\
\hline & FOL & III.2001 & Teresópolis, RJ, , BR & $\begin{array}{l}\text { Notostrix sp. } 7^{*} \\
\text { Palmiphytoptus oculatus* } \\
\text { Propilus syagris }+\end{array}$ \\
\hline & FOL, BT ${ }^{12}$ & $\begin{array}{l}\text { I }^{2} \text { III; IV; } X^{1} \\
2000\end{array}$ & Pariquera-Açu, SP, BR & $\begin{array}{l}{ }^{1} \text { Palmiphytoptus oculatus* } \\
{ }^{2} \text { Propilus syagris }\end{array}$ \\
\hline Astrocaryum gynacanthum & FOL & IX.2003 & Manaus, AM, BR & \\
\hline Astrocaryum murumuru & FOL & XI.2000 & Piracicaba, SP, BR & \\
\hline Astrocaryum vulgare & FOL & IV.2000 & Campinas, SP, BR & \\
\hline Attalea phalerata & FOL, FRU & IV.2000 & Campinas, SP, BR & \\
\hline Attalea aff. amygdalina & FOL & VII. 2000 & Campinas, SP, BR & \\
\hline Attalea dubia & $\mathrm{FOL}^{2}, \mathrm{BT}^{1}$ & $\begin{array}{l}\text { I }^{2} \text { III; IV } \text { IV }^{12} \\
\mathrm{X}^{12} \cdot 2000\end{array}$ & Pariquera-Açu, SP, BR & $\begin{array}{l}{ }^{1} \text { Aceria translinea* } \\
{ }^{2} \text { Notostrix sp. } 2 *\end{array}$ \\
\hline \multirow[t]{3}{*}{ Attalea geraensis } & $\mathrm{FOL}^{1}, \mathrm{FRU}, \mathrm{BT}$ & VII; X; XII ${ }^{1} .2000$ & Luiz Antonio, SP, BR & ${ }^{1}$ Notostrix butiae \\
\hline & $\mathrm{FOL}^{12} \mathrm{FRU}, \mathrm{BT}$ & VII; XII ${ }^{12} 2000$ & São Carlos, SP , BR & $\begin{array}{l}{ }^{1} \text { Notostrix butiae } \\
{ }^{2} \text { Amrineus cocofolius }\end{array}$ \\
\hline & $\mathrm{FOL}^{1}, \mathrm{FRU}, \mathrm{BT}$ & VII; X; XII ${ }^{1} .2000$ & Pirassununga, SP, BR & ${ }^{1}$ Notostrix butiae+ \\
\hline Attalea lauromuelleriana & FOL & IX.2000 & Campinas, SP, BR & \\
\hline Attalea maripa & FOL & VI. 2000 & Campinas, SP, BR & \\
\hline Attalea microcarpa & FRU & IX.2003 & Manaus, AM, BR & \\
\hline
\end{tabular}


Tabela 1. Eriophyoidea associados a palmeiras em diferentes localidades do Brasil, Costa Rica e México. Espécies de palmeiras e partes das plantas amostradas, mês de coleta, localidade e espécies de ácaros encontradas. (FOL- folíolos; BTbroto terminal; FRU- frutos; INFL- inflorescências; BR- Brasil; Mx- México; CR- Costa Rica) (* novos táxons; + novo hospedeiro; $\square$ nova localidade (país ou estado))

\begin{tabular}{|c|c|c|c|c|}
\hline Palmeira & Parte da Planta & Mês de Coleta & Localidade & Eriophyoidea \\
\hline Attalea sp. & FOL, FRU & IV.2000 & Campinas, SP, BR & \\
\hline Attalea speciosa & FOL & IV; VI. 2000 & Campinas, SP, BR & \\
\hline Bactris bahiensis & FOL & IX. 2000 & Campinas, SP, BR & \\
\hline Bactris caryotifolia & FOL, BT & III. 2001 & Teresópolis, RJ, BR & \\
\hline \multirow[t]{2}{*}{ Bactris gasipes } & FOL, BT & X.2000 & Piracicaba, SP, BR & \\
\hline & FOL & IX. 2003 & Guápiles, Limón, CR & Retracrus johnstoni \\
\hline Bactris mexicana & FOL & IX.2000 & Campinas, SP, BR & \\
\hline Bactris ottostaffeana & FOL & IX.2000 & Campinas, SP, BR & \\
\hline \multirow[t]{5}{*}{ Bactris setosa } & $\begin{array}{l}\text { FOL; } \text { BT }^{1} \\
\text { FRU }\end{array}$ & I; III; X1 2000 & Cananéia, SP, BR & ${ }^{1}$ Palmiphytoptus oculatus* \\
\hline & FOL & VI.2000 & Campinas, SP, BR & \\
\hline & FOL, BT & X.2000 & Piracicaba, SP, BR & \\
\hline & FOL & $\begin{array}{l}\mathrm{IX}^{1} .2000 \\
\mathrm{I}^{1} .2001\end{array}$ & Jundiaí, SP, BR & ${ }^{1}$ Propilus spinosus \\
\hline & $\mathrm{FOL}^{2,3,4,5} ; \mathrm{BT}^{12}$ & $\begin{array}{l}\mathrm{I}^{3,4} ; \mathrm{III} ; \mathrm{IV}^{1,2} ; \\
\mathrm{VIII}^{3} ; \mathrm{X}^{4,5} .2000\end{array}$ & Pariquera-Açu, SP, BR & $\begin{array}{l}{ }^{1} \text { Palmiphytoptus oculatus* } \\
{ }^{2} \text { Notostrix exigua }+ \\
{ }^{3} \text { Notostrix sp.4* } \\
{ }^{4} \text { Propilus spinosus } \\
{ }^{5} \text { Retracrus johnstoni }\end{array}$ \\
\hline Bactris sp. & FOL & IX.2003 & Manaus, AM, BR & \\
\hline
\end{tabular}


Tabela 1. Eriophyoidea associados a palmeiras em diferentes localidades do Brasil, Costa Rica e México. Espécies de palmeiras e partes das plantas amostradas, mês de coleta, localidade e espécies de ácaros encontradas. (FOL- folíolos; BTbroto terminal; FRU- frutos; INFL- inflorescências; BR- Brasil; Mx- México; CR- Costa Rica) (* novos táxons; + novo hospedeiro; $\square$ nova localidade (país ou estado))

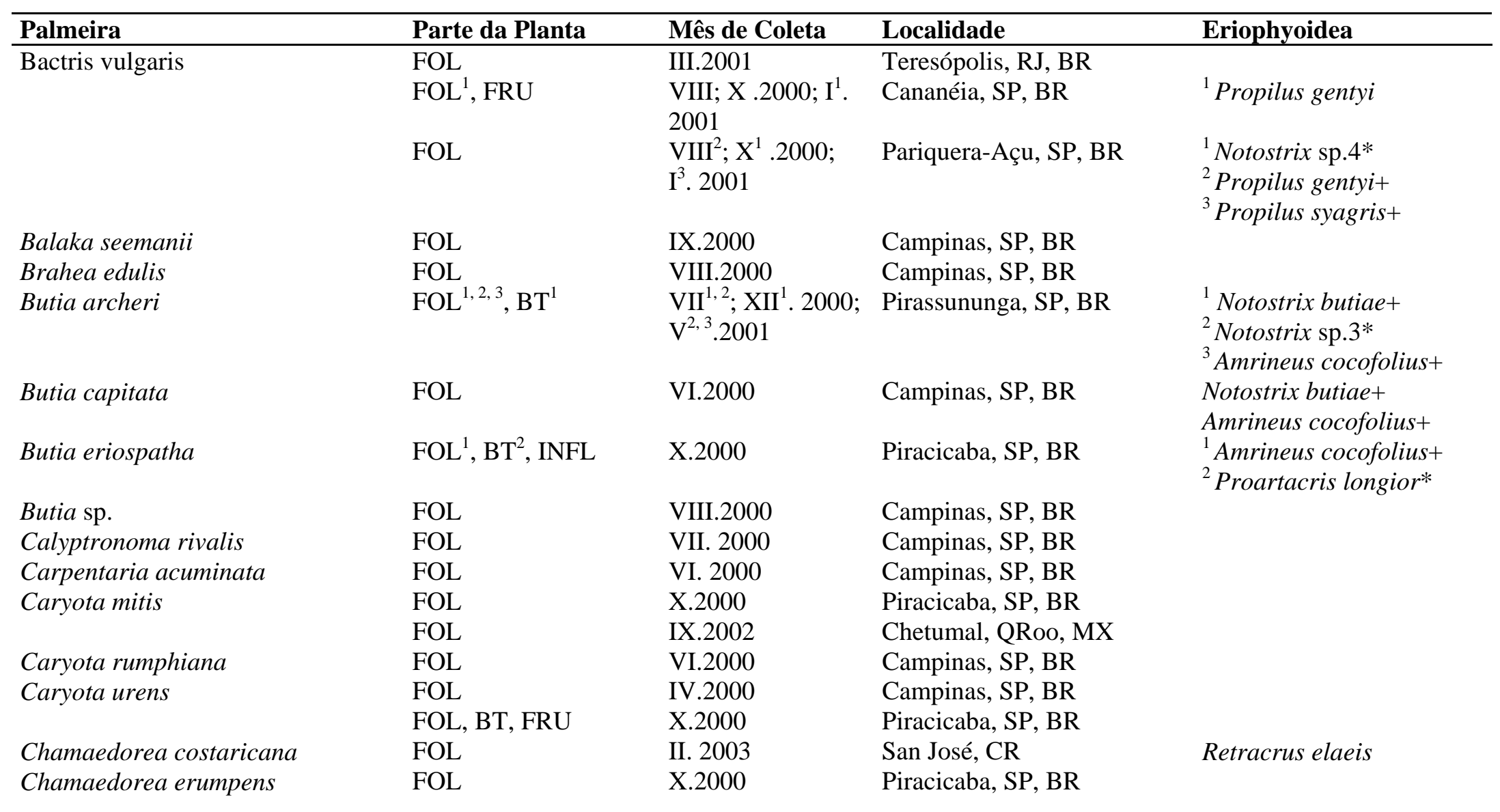


Tabela 1. Eriophyoidea associados a palmeiras em diferentes localidades do Brasil, Costa Rica e México. Espécies de palmeiras e partes das plantas amostradas, mês de coleta, localidade e espécies de ácaros encontradas. (FOL- folíolos; BTbroto terminal; FRU- frutos; INFL- inflorescências; BR- Brasil; Mx- México; CR- Costa Rica) (* novos táxons; + novo hospedeiro; $\square$ nova localidade (país ou estado))

\begin{tabular}{llll}
\hline Palmeira & Parte da Planta & Mês de Coleta & Localidade \\
\hline Chamaedorea fragrans & FOL, FRU & IX.2000 & Campinas, SP, BR \\
Chamaedorea klotzchiana & FOL, FRU & VII. 2000 & Campinas, SP, BR \\
Chamaedorea metallica & FOL & IV. 2000 & Campinas, SP, BR \\
Chamaedorea microspadix & FOL & IX.2000 & Campinas, SP, BR \\
Chamaedorea oblongata & FOL & X.2000 & Piracicaba, SP, BR \\
Chamaedorea radicalis & FOL, FRU & X.2000 & Piracicaba, SP, BR \\
Chamaedorea seifrizii & FOL & VI.2000 & Campinas, S, BR \\
& FOL, INFL & VII. 2000 & Campinas, SP, BR \\
Chamaedorea sp. & FOL & IX.2002 & Chetumal, QRoo, MX \\
Chamaedorea stolonifera & FOL & IX.2000 & Campinas, SP, BR \\
Chamaedorea tapejilote & FOL & IX.2000 & Campinas, SP, BR \\
& FOL & IX.2000 & Campinas, SP, BR \\
& FOL & X.2000 & Piracicaba, SP, BR \\
Chamaerops sp. & FOL & VI.2000 & Campinas, SP, BR \\
Chambeyronea macrocarpa & FOL, FRU, BT, INFL X.2000 & Piracicaba, SP, BR \\
Coccothrinax argentata & FOL, BT & VI.2000 & Campinas, SP, BR \\
& FOL & VI.2000 & Campinas, SP, BR \\
Coccothrinax barbadensis & FOL & IX.2002 & Chetumal, QRoo, MX \\
Coccothrinax fragans & FOL & IX.2000 & Campinas, SP, BR \\
Coccothrinax miraguama & FOL & VI.2000 & Campinas, SP, BR \\
Cocos nucifera & FOL, FRU & XI.2000 & Piracicaba, SP, BR \\
& FOL, FRU & IX.2000 & Campinas, SP, BR \\
& FOL & VI.2000 & Campinas, SP, BR \\
& & XI.2000 & Piracicaba, SP, BR
\end{tabular}


Tabela 1. Eriophyoidea associados a palmeiras em diferentes localidades do Brasil, Costa Rica e México. Espécies de palmeiras e partes das plantas amostradas, mês de coleta, localidade e espécies de ácaros encontradas. (FOL- folíolos; BTbroto terminal; FRU- frutos; INFL- inflorescências; BR- Brasil; Mx- México; CR- Costa Rica) (* novos táxons; + novo hospedeiro; $\square$ nova localidade (país ou estado))

\begin{tabular}{|c|c|c|c|c|}
\hline Palmeira & Parte da Planta & Mês de Coleta & Localidade & Eriophyoidea \\
\hline & $\mathrm{FOL}^{1}, \mathrm{BT}$ & IX.2002 & Chetumal,QRoo, MX & ${ }^{1}$ Notostrix nasutiformes $\square$ \\
\hline & FOL & IX.2002 & Celestún, Yucatan, MX & \\
\hline & FOL & IX.2002 & Tulum, Yucatan, MX & \\
\hline & FOL & IX.2003 & Manaus, AM, BR & Notostrix nasutiformes $\square$ \\
\hline Copernicia alba & FOL & VII. 2000 & Campinas, SP, BR & \\
\hline Copernicia hospita & FOL & VII. 2000 & Campinas, SP, BR & \\
\hline Copernicia prunifera & FOL & V.2000 & Campinas, SP, BR & \\
\hline Corypha sp. & FOL & VI.2000 & Campinas, SP, BR & \\
\hline Cryosophila nana & FOL & X.2000 & Piracicaba, SP, BR & \\
\hline Desmoncus orthocanthos & FOL & X.2000 & Piracicaba, SP, BR & \\
\hline Desmoncus sp. & FOL & VI.2000 & Campinas, SP, BR & \\
\hline \multirow[t]{2}{*}{ Dictyosperma album } & FOL, FRU & XI.2000 & Piracicaba, SP, BR & \\
\hline & FOL & V.2000 & Campinas, SP, BR & \\
\hline Dictyosperma rubrum & FOL & VII. 2000 & Campinas, SP, BR & \\
\hline Dypsis decary & FOL & VII. 2000 & Campinas, SP, BR & \\
\hline \multirow[t]{2}{*}{ Dypsis lutescens } & FOL & VII. 2000 & Campinas, SP, BR & \\
\hline & $\mathrm{FOL}, \mathrm{BT}$ & X.2000 & Piracicaba, SP, BR & \\
\hline \multirow[t]{4}{*}{ Elaeis guineensis } & FOL & XI.2000 & Piracicaba, SP, BR & \\
\hline & FOL & IX 2003 & Manaus, AM BR & \\
\hline & FOL & VI.2000 & Campinas, SP, BR & \\
\hline & FOL & V. 2003 & Puntarenas, CR & Retracrus elaeis \\
\hline Elaeis oleifera & FOL & IX.2003 & Manaus, AM, BR & Propilus sp.2* \\
\hline Erythea brandegeei & FOL & IV.2000 & Campinas, SP, BR & \\
\hline Euterpe edulis & $\mathrm{FOL}^{1}, \mathrm{BT}, \mathrm{INFL}, \mathrm{FRU}$ & II.; V; XI ${ }^{1} .2000$ & Ibicatu, Piracicaba, SP, BR & ${ }^{1}$ Retracrus johnstoni \\
\hline
\end{tabular}


Tabela 1. Eriophyoidea associados a palmeiras em diferentes localidades do Brasil, Costa Rica e México. Espécies de palmeiras e partes das plantas amostradas, mês de coleta, localidade e espécies de ácaros encontradas. (FOL- folíolos; BTbroto terminal; FRU- frutos; INFL- inflorescências; BR- Brasil; Mx- México; CR- Costa Rica) (* novos táxons; + novo hospedeiro; $\square$ nova localidade (país ou estado))

\begin{tabular}{|c|c|c|c|c|}
\hline Palmeira & Parte da Planta & Mês de Coleta & Localidade & Eriophyoidea \\
\hline & FOL & $\mathrm{X}^{1} .2000$ & Piracicaba, SP, BR & ${ }^{1}$ Notostrix exígua \\
\hline & FOL, BT & IX.2000; I I .2001 & Jundiaí, SP, BR & ${ }^{1}$ Retracrus johnstoni \\
\hline & FOL & III.2001 & Teresópolis, RJ, BR & Notostrix exígua \\
\hline & FOL, BT ${ }^{1}$, INFL, FRU & I; III; IV ; X. 2000 & Pariquera-Açu, SP, BR & ${ }^{1}$ Glabrisceles euterpis* \\
\hline & FOL, BT, FRU & I; III; IV; X. 2000 & Cananéia, SP, BR & \\
\hline & FOL, BT & II: V; XI. 2000 & Ibicatu, Piracicaba, SP, BR & \\
\hline \multirow[t]{2}{*}{ Euterpe oleracea } & FOL & IX.2003 & Manaus, AM, BR & \multirow{3}{*}{$\begin{array}{l}\text { Glabrisceles sp. } \text { 1* }^{*} \\
{ }^{1} \text { Retracrus johnstoni } \\
{ }^{1} \text { Notostrix sp. } 8^{*} \\
{ }^{2} \text { Retracrus johnstoni+ } \\
{ }^{3} \text { Glabrisceles sp.2* }\end{array}$} \\
\hline & $\mathrm{FOL}^{1}, \mathrm{BT}$ & X.2000 & Piracicaba, SP, BR & \\
\hline Euterpe precatoria & $\mathrm{FOL}^{1,2,3}, \mathrm{BT}$ & IX.2003 & Manaus, AM, BR & \\
\hline Euterpe sp. & FOL & VI.2000 & Campinas, SP, BR & \\
\hline Gaussia maya & FOL & VI.2000 & Campinas, SP, BR & \\
\hline Gaussia attenuata & FOL & VI.2000 & Campinas, SP, BR & \\
\hline Geonoma aspidifolia & FOL, BT & IX.2003 & Manaus, AM, BR & \\
\hline Geonoma blanchetiana & FOL & III.2001 & Teresópolis, RJ, BR & \\
\hline Geonoma brevispatha & FOL, $\mathrm{BT}^{1}, \mathrm{FRU}$ & II; V; XI ${ }^{1} .2000$ & São Pedro, SP, BR & ${ }^{1}$ Acathrix lobata* \\
\hline \multirow{2}{*}{ Geonoma elegans } & FOL & VI. 2000 & Campinas, SP, BR & \\
\hline & FOL & VIII; X. 2000 & Pariquera-Açu, SP, BR & \\
\hline \multirow[t]{2}{*}{ Geonoma gamiovora } & $\mathrm{FOL}^{1}, \mathrm{BT}$ & VII; XII ${ }^{1} .2000$ & Luiz Antonio, SP, BR & ${ }^{1}$ Nasuchus pindobates* \\
\hline & FOL & VIII' $;$ X. 2000 & Pariquera-Açu, SP, BR & ${ }^{1}$ Retracrus johnstoni \\
\hline \multirow[t]{3}{*}{ Geonoma schottiana } & $\mathrm{FOL}^{2}, \mathrm{BT}^{1,3}, \mathrm{FRU}$ & I; VIII' ${ }^{2,3} ; X^{1,}$ & Cananéia, SP, BR & ${ }^{1}$ Acathrix lobata* \\
\hline & & ${ }^{2} 2000$ & & $\begin{array}{l}{ }^{2} \text { Retracrus johnstoni } \\
{ }^{3} \text { Knorella geonomae }\end{array}$ \\
\hline & $\mathrm{FOL}^{1}, \mathrm{BT}^{2}$ & $\begin{array}{l}\mathrm{IV}^{2} ; \mathrm{VIII}^{1} ; \mathrm{X}^{1} . \\
2000\end{array}$ & Pariquera-Açu, SP, BR & $\begin{array}{l}{ }^{1} \text { Retracrus johnstoni } \\
{ }^{2} \text { Knorella geonomae }\end{array}$ \\
\hline
\end{tabular}


Tabela 1. Eriophyoidea associados a palmeiras em diferentes localidades do Brasil, Costa Rica e México. Espécies de palmeiras e partes das plantas amostradas, mês de coleta, localidade e espécies de ácaros encontradas. (FOL- folíolos; BTbroto terminal; FRU- frutos; INFL- inflorescências; BR- Brasil; Mx- México; CR- Costa Rica) (* novos táxons; + novo hospedeiro; $\square$ nova localidade (país ou estado))

\begin{tabular}{|c|c|c|c|c|}
\hline Palmeira & Parte da Planta & Mês de Coleta & Localidade & Eriophyoidea \\
\hline \multirow[t]{4}{*}{ Geonoma sp. } & FOL & $\begin{array}{l}\text { VII; XII. 2000; } \\
\text { VII }^{1,2} .2001\end{array}$ & São Carlos, SP, , BR & $\begin{array}{l}{ }^{1} \text { Acathrix lobata* } \\
{ }^{2} \text { Retracrus johnstoni }\end{array}$ \\
\hline & FOL & II.2001 & Cotia, SP, BR & Schizacea geonomae* \\
\hline & FOL & III.2001 & Teresópolis, RJ, BR & Schizacea geonomae* \\
\hline & FRU & I; X. 2000 & Cananéia, SP, BR & \\
\hline Guilielma speciosa & FOL, FRU & V.2000 & Campinas, SP, BR & \\
\hline \multirow[t]{2}{*}{ Heterospathe elata } & FOL & V.2000 & Campinas, SP, BR & \\
\hline & FOL & X.2000 & Piracicaba, SP, BR & \\
\hline Heterospathe negroensis & FOL & V.2000 & Campinas, SP, BR & \\
\hline Heterospathe phillipinensis & FOL, BT & IX.2000 & Campinas, SP, BR & \\
\hline Howea forsteriana & FOL & VII. 2000 & Campinas, SP, BR & \\
\hline Hyophorbe lagenicaulis & FOL & V.2000 & Campinas, SP, BR & \\
\hline Hyophorbe verschaffeltii & FOL & V.2000 & Campinas, SP, BR & \\
\hline Iriartea sp. & FOL & IX.2000 & Campinas, SP, BR & \\
\hline Iriartella setigera & FOL & IX.2003 & Manaus, AM, BR & \\
\hline Laccospadix sp. & FOL & VI.2000 & Campinas, SP, BR & \\
\hline Latania loddigesii & FOL & IX.2000 & Campinas, SP, BR & \\
\hline Licuala grandis & FOL & X.2000 & Piracicaba, SP, BR & \\
\hline Licuala jeanencyi & FOL, FRU & VII. 2000 & Campinas, SP, BR & \\
\hline Licuala peltata & FOL & IX.2000 & Campinas, SP, BR & \\
\hline Licuala rumphi & FOL, BT & IX.2000 & Campinas, SP, BR & \\
\hline Licuala spinosa & FOL, FRU & X.2000 & Piracicaba, SP, BR & \\
\hline \multirow[t]{2}{*}{ Livistona australis } & FOL & V.2000 & Campinas, SP, BR & \\
\hline & FOL, FRU & XI.2000 & Piracicaba, SP, BR & \\
\hline Livistona chinensis & FOL, FRU & X.2000 & Piracicaba, SP, BR & \\
\hline
\end{tabular}


Tabela 1. Eriophyoidea associados a palmeiras em diferentes localidades do Brasil, Costa Rica e México. Espécies de palmeiras e partes das plantas amostradas, mês de coleta, localidade e espécies de ácaros encontradas. (FOL- folíolos; BTbroto terminal; FRU- frutos; INFL- inflorescências; BR- Brasil; Mx- México; CR- Costa Rica) (* novos táxons; + novo hospedeiro; $\square$ nova localidade (país ou estado))

\begin{tabular}{|c|c|c|c|c|}
\hline Palmeira & Parte da Planta & Mês de Coleta & Localidade & Eriophyoidea \\
\hline Livistona decipiens & FOL & VII. 2000 & Campinas, SP, BR & \\
\hline Livistona merrilii & FOL & VI.2000 & Campinas, SP, BR & \\
\hline Livistona rigida & FOL & VI.2000 & Campinas, SP, BR & \\
\hline \multirow[t]{2}{*}{ Livistona rotundifolia } & FOL & V.2000 & Campinas, SP, BR & \\
\hline & FOL & X.2000 & Piracicaba, SP, BR & \\
\hline \multirow[t]{2}{*}{ Livistona saribus } & FOL, FRU & VI.2000 & Campinas, SP, BR & \\
\hline & FOL, FRU & XI.2000 & Piracicaba, SP, BR & \\
\hline Lytocaryum hoehnei & FOL, BT & II.2001 & Cotia, SP, BR & $\begin{array}{l}\text { Notostrix sp.5* } \\
\text { Propilus pellitus* }\end{array}$ \\
\hline Lytocaryum weddellianum & FOL, BT & III.2001 & Teresópolis, RJ, BR & \\
\hline Mascarena sp. & FOL & VI.2000 & Campinas, SP, BR & \\
\hline Mauritia flexuosa & FOL & IX.2003 & Manaus, AM, BR & $\begin{array}{l}\text { Notostrix sp. } 8^{*} \\
\text { Propilus sp. } 1^{*} \\
\text { Retracrus johnstoni+ }\end{array}$ \\
\hline Oenocarpus sp. & FOL & VI.2000 & Campinas, SP, BR & \\
\hline \multirow[t]{2}{*}{ Phoenix dactylifera } & FOL, FRU & V.2000 & Campinas, SP, BR & \\
\hline & FOL & X.2000 & Piracicaba, SP, BR & \\
\hline Phoenix loureirii & FOL & VIII.2000 & Campinas, SP, BR & \\
\hline Phoenix reclinata & FOL, BT & X.2000 & Piracicaba, SP, BR & \\
\hline Phoenix roebelenii & FOL, BT, INFL & X.2000 & Piracicaba, SP, BR & \\
\hline \multirow[t]{2}{*}{ Phoenix rupicola } & FOL & VI.2000 & Campinas, SP, BR & \\
\hline & FOL & X.2000 & Piracicaba, SP, BR & \\
\hline
\end{tabular}


Tabela 1. Eriophyoidea associados a palmeiras em diferentes localidades do Brasil, Costa Rica e México. Espécies de palmeiras e partes das plantas amostradas, mês de coleta, localidade e espécies de ácaros encontradas. (FOL- folíolos; BTbroto terminal; FRU- frutos; INFL- inflorescências; BR- Brasil; Mx- México; CR- Costa Rica) (* novos táxons; + novo hospedeiro; $\square$ nova localidade (país ou estado))

\begin{tabular}{llll}
\hline Palmeira & Parte da Planta & Mês de Coleta & Localidade \\
\hline Phytelephas macrocarpa & FOL & VI.2000 & Campinas, SP, BR \\
Pinanga elmerii & FOL & IX.2000 & Campinas, SP, BR \\
Pinanga kuhlii & FOL, BT & IX.2000 & Campinas, SP, BR \\
Pinanga merrillii & FOL, BT & IX.2000 & Campinas, SP, BR \\
Pinanga sp. & FOL & IV.2000 & Campinas, SP, BR \\
Polyandrococos caudescens & FOL & V.2000 & Campinas, SP, BR \\
& FOL & X.2000 & Piracicaba, SP, BR \\
Pseudophoenix sargentii & FOL & IX.2002 & Chetumal, QRoo, MX \\
Ptychosperma angustifolium & FOL & VII. 2000 & Campinas, SP, BR \\
Ptychosperma elegans & FOL & VII. 2000 & Campinas, SP, BR \\
Ptychosperma macarthurii & FOL & VII. 2000 & Campinas, SP, BR \\
& FOL, FRU & X.2000 & Piracicaba, SP, BR \\
Ptychosperma sp. & FOL & IV; VII. 2000 & Campinas, SP, BR \\
Raphia farinifera & FOL & VI.2000 & Campinas, SP, BR \\
Ravenea sp. & FOL & VI.2000 & Campinas, SP, BR \\
Reinhardtia sp. & FOL, FRU & IX.2000 & Campinas, SP, BR \\
Rhapis excelsa & FOL & X.2000 & Piracicaba, SP, BR \\
& FOL & IX.2000 & Campinas, SP, BR \\
Roystonea borinquena & FOL & X.2000 & Piracicaba, SP, BR \\
Roystonea oleraceae & FOL, FRU & XI.2000 & Piracicaba, SP, BR \\
Roystonea princeps & FOL & IX.2000 & Campinas, SP, BR \\
Roystonea regia & FOL, FRU & XI.2000 & Piracicaba, SP, BR \\
Roystonea sp. & FOL & VI.2000 & Campinas, SP, BR \\
Sabal bermudana & FOL & VIII.2000 & Campinas, SP, BR \\
Sabal etonia & FOL & VIII.2000 & Campinas, SP, BR \\
& & &
\end{tabular}


Tabela 1. Eriophyoidea associados a palmeiras em diferentes localidades do Brasil, Costa Rica e México. Espécies de palmeiras e partes das plantas amostradas, mês de coleta, localidade e espécies de ácaros encontradas. (FOL- folíolos; BTbroto terminal; FRU- frutos; INFL- inflorescências; BR- Brasil; Mx- México; CR- Costa Rica) (* novos táxons; + novo hospedeiro; $\square$ nova localidade (país ou estado))

\begin{tabular}{|c|c|c|c|c|}
\hline Palmeira & Parte da Planta & Mês de Coleta & Localidade & Eriophyoidea \\
\hline \multirow[t]{2}{*}{ Sabal mauritiformis } & FOL & IX.2002 & Chetumal, QRoo, MX & \\
\hline & FOL, BT & X.2000 & Piracicaba, SP, BR & \\
\hline \multirow[t]{2}{*}{ Sabal mexicanum } & FOL, FRU & VI; IX. 2000 & Campinas, SP, BR & \\
\hline & FOL & X.2000 & Piracicaba, SP, BR & \\
\hline \multirow[t]{2}{*}{ Sabal minor } & FOL, FRU & V.2000 & Campinas, SP, BR & \\
\hline & FOL, BT & X.2000 & Piracicaba, SP, BR & \\
\hline Sabal sp. & FOL & IX.2002 & Chichen Itzá, Yucatan, MX & Notostrix sp. $6 *$ \\
\hline \multirow[t]{2}{*}{ Sabal yapa } & FOL & IX.2002 & Chetumal, QRoo, MX & \\
\hline & FOL & VII.2000 & Campinas, SP, BR & \\
\hline Scheelea ceanchocina & FOL, FRU & V.2000 & Campinas, SP, BR & \\
\hline \multirow[t]{2}{*}{ Scheelea sp. } & $\mathrm{FOL}^{1}, \mathrm{FRU}$ & V.2000 & Campinas, SP, BR & ${ }^{1}$ Retracrus johnstoni+ \\
\hline & FOL & X.2000 & Piracicaba, SP, BR & \\
\hline Serenoa repens & FOL & VIII.2000 & Campinas, SP, BR & \\
\hline Socratea exorrhiza & FOL & XI.2000 & Piracicaba, SP, BR & \\
\hline Strongylocarium sp. & FOL & IX.2000 & Campinas, SP, BR & \\
\hline Syagrus brotryophora & FOL & V.2000 & Campinas, SP, BR & \\
\hline Syagrus cocoides & FOL, FRU ${ }^{1}$ & IV; $V^{1} .2000$ & Campinas, SP, BR & ${ }^{1}$ Aceria gymnoscuta* \\
\hline Syagrus comosa & FOL & VII. 2000 & Campinas, SP, BR & \\
\hline \multirow[t]{2}{*}{ Syagrus coronata } & FOL, FRU & VI.2000 & Campinas, SP, BR & \\
\hline & FOL, FRU & X.2000 & Piracicaba, SP, BR & \\
\hline \multirow[t]{2}{*}{ Syagrus flexuosa } & FOL & VI.2000 & Campinas, SP, BR & \\
\hline & $\mathrm{FOL}^{1}, \mathrm{FRU}, \mathrm{BT}$ & $\begin{array}{l}\mathrm{IX}^{1} .2000 \\
\mathrm{I}^{1} .2001\end{array}$ & Jundiaí, SP, BR & ${ }^{1}$ Aceria gymnoscuta* \\
\hline \multirow[t]{2}{*}{ Syagrus inajai } & FOL & VII; IX 2000 & Campinas, SP, BR & \\
\hline & FOL & IX.2003 & Manaus, AM, BR & \\
\hline
\end{tabular}


Tabela 1. Eriophyoidea associados a palmeiras em diferentes localidades do Brasil, Costa Rica e México. Espécies de palmeiras e partes das plantas amostradas, mês de coleta, localidade e espécies de ácaros encontradas. (FOL- folíolos; BTbroto terminal; FRU- frutos; INFL- inflorescências; BR- Brasil; Mx- México; CR- Costa Rica) (* novos táxons; + novo hospedeiro; $\square$ nova localidade (país ou estado))

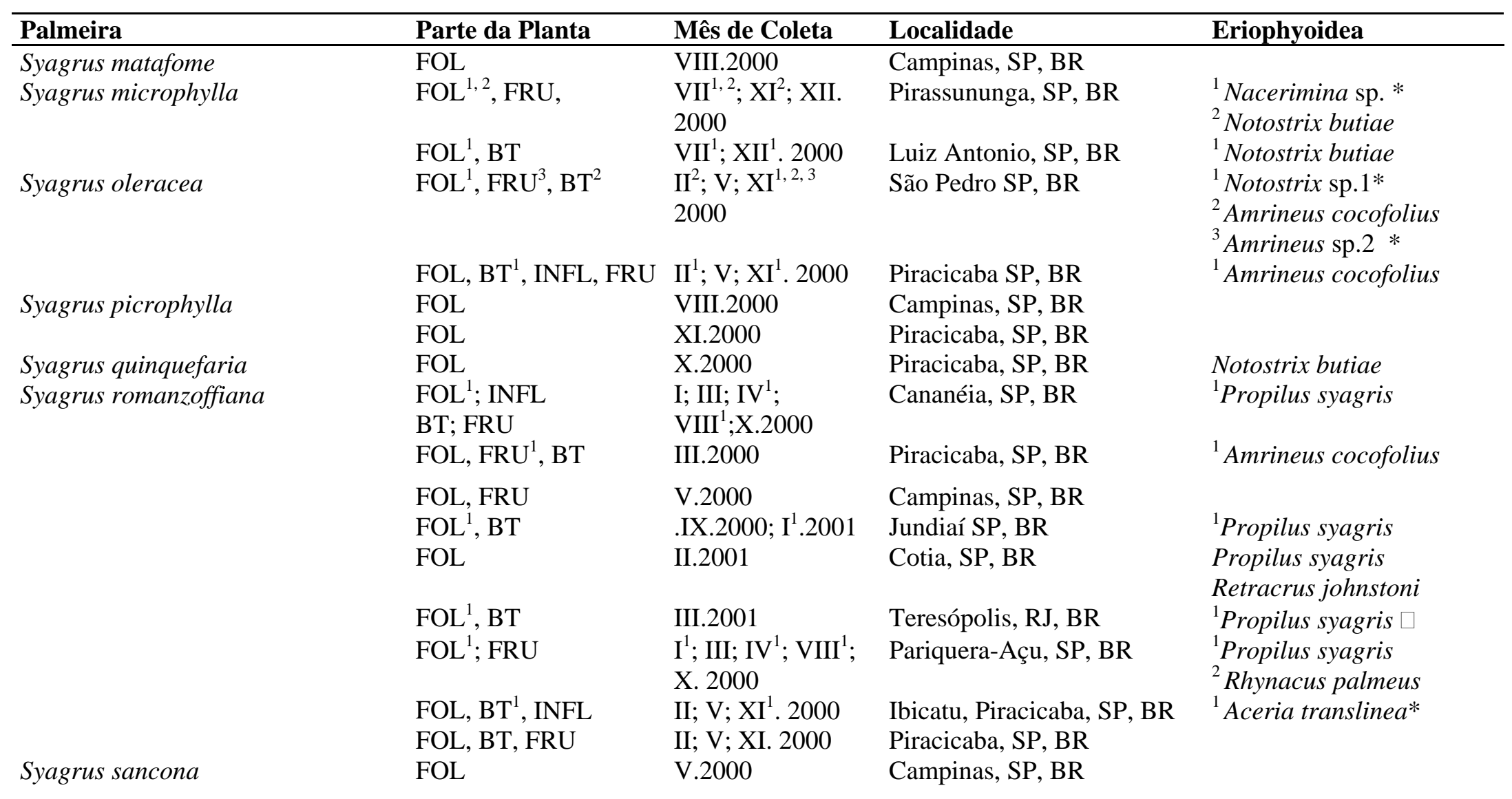


Tabela 1. Eriophyoidea associados a palmeiras em diferentes localidades do Brasil, Costa Rica e México. Espécies de palmeiras e partes das plantas amostradas, mês de coleta, localidade e espécies de ácaros encontradas. (FOL- folíolos; BTbroto terminal; FRU- frutos; INFL- inflorescências; BR- Brasil; Mx- México; CR- Costa Rica) (* novos táxons; + novo hospedeiro; $\square$ nova localidade (país ou estado))

\begin{tabular}{|c|c|c|c|c|}
\hline Palmeira & Parte da Planta & Mês de Coleta & Localidade & Eriophyoidea \\
\hline Syagrus sp. & FOL, FRU & VI.2000 & Campinas, SP, BR & \\
\hline Syagrus vagans & FOL & VIII.2000 & Campinas, SP, BR & \\
\hline Synechanthus sp. & FOL, FRU & IX.2000 & Campinas, SP, BR & \\
\hline Thrinax parviflora & FOL, FRU & V;VI.2000 & Campinas, SP, BR & \\
\hline \multirow[t]{3}{*}{ Thrinax radiata } & FOL, $\mathrm{BT}^{1}$ & IX.2002 & Chetumal, QRoo, MX, & ${ }^{1}$ Acathrix sp.1* \\
\hline & $\mathrm{FOL}^{1}, \mathrm{BT}$ & IX.2002 & Tulum, Yucatan, MX & ${ }^{1}$ Acathrix sp. $1^{*}$ \\
\hline & FOL & VIII.2000 & Campinas, SP, BR & \\
\hline \multirow[t]{2}{*}{ Trachycarpus fortunei } & FOL & X.2000 & Piracicaba, SP, BR & \\
\hline & FOL & VI.2000 & Campinas, SP, BR & \\
\hline Trachycarpus wagnerianus & FOL & IX.2000 & Campinas, SP, BR & \\
\hline Trithrinax acanthocoma & FOL, BT & IX.2000 & Campinas, SP, BR & \\
\hline Trithrinax brasiliensis & FOL & VI.2000 & Campinas, SP, BR & \\
\hline Veitchia joannis & FOL & IX.2000 & Campinas, SP, BR & \\
\hline \multirow[t]{2}{*}{ Veitchia merrilli } & FOL, INFL & IV; VI. 2000 & Campinas, SP, BR & \\
\hline & FOL, BT & X.2000 & Piracicaba, SP, BR & \\
\hline Veitchia sp. & FOL & V.2000 & Campinas, SP, BR & \\
\hline Wallichia disticha & FOL & IV.2000 & Campinas, SP, BR & \\
\hline Washingtonia sp. & FOL & V.2000 & Campinas, SP, BR & \\
\hline Wodyetia bifurcata & FOL & IX.2000 & Campinas, SP, BR & \\
\hline
\end{tabular}


Portanto, a presença deste eriofiídeo foi constatada em áreas próximas a algumas das áreas onde foram realizadas as coletas de Eriophyoidea associados às diversas espécies de Arecaceae. Esta constatação foi importante porque foram consideradas maiores as possibilidades de encontrar A. guerreronis em novas palmeiras hospedeiras em localidades onde havia sido constatada a presença do ácaro do que em áreas onde nem sequer havia sido confirmada a presença da espécie.

Foram coletadas neste trabalho 38 espécies de Eriophyoidea, de 14 gêneros, em 34 espécies de palmeiras (Tabela 1). Vinte e seis das espécies e três dos gêneros de Eriophyoidea eram novos táxons. Dentre estes, 16 espécies e 3 gêneros já foram descritas (Capítulo 4). As demais espécies serão descritas em breve.

Além dos táxons novos, foram relacionados 18 novos hospedeiros para seis das espécies coletadas: Attalea geraensis Barb. rodr., B. archeri, B. eriospatha, Butia capitata (Mart.) Becc. e Syagrus oleracea (Mart.) Becc. para A. cocofolius; A. geraensis, B. archeri, B. capitata, Syagrus microphylla Burret e Syagrus quinquefaria Becc. para N. butiae; B. setosa para N. exigua; Bactris vulgaris Barb. Rodr. para P. gentyi; A. aculeatissimum e B. vulgaris para P. syagris; Euterpe precatória Mart., Mauritia flexuosa L. e Scheelea sp. para R. johnstoni; e C. costaricana para R. elaeis (Tabela 1).

Além de registros de novos hospedeiros, registrou-se pela primeira vez a presença de $N$. nasutiformes no México, em folhas de coqueiros. Registrou-se também, no Brasil, a ocorrência de algumas espécies de Eriophyoidea em outros Estados além daqueles onde eram conhecidos: $N$. nasutiformes no Estado do Amazonas, também em folhas de coqueiros e $P$. syagris no Estado do Rio de Janeiro, em folhas de $S$. romanzoffiana.

A quase totalidade dos Eriophyoidea foi coletada sobre as palmeiras em suas respectivas áreas de ocorrência natural (Tabela 1). Das 160 espécies amostradas na coleção de palmeiras do IAC, Campinas, SP e/ou no Parque da ESALQ, Piracicaba, SP, 151 são introduzidas. Colônias de Eriophyoidea foram encontradas em apenas seis delas (B. capitata; B. eriospatha; C. nucifera; E. oleraceae; Syagrus cocoides Mart. e S. coronata (Mart.) Becc.), não sendo constatados ácaros Eriophyoidea em associação com as demais. Dentre aquelas seis espécies de palmeiras “introduzidas”, no Estado de São 
Paulo, C. nucifera é a de maior importância econômica. É provável que os ácaros associados a esta espécie venham sendo disseminados juntamente com material de propagação. As espécies de Butia (B. capitata e B. eriospatha) e de Syagrus (S. cocoides e $S$. coronata) não ocorrem naturalmente no Estado de São Paulo, mas em estados vizinhos (Paraná e Minas Gerais, respectivamente). Há um grande número de espécies destes gênero no Estado de São Paulo. É possível que os eriofí́deos associados a estas espécies de Butia e Syagrus estejam sendo disseminadas a curtas distâncias pelo vento, transportados com material de propagação vegetativa ou infestando hospedeiros de um mesmo gênero em áreas distintas. A única espécie de palmeira introduzida de regiões distantes, em que foram encontradas colônias de eriofiídeos no Estado de São Paulo, foi E. oleracea, o palmito açaí, nativo da região amazônica, o qual foi encontrado infestado por $R$. johnstoni, um eriofiídeo que apresenta grande número de palmeiras hospedeiras (Gondim Jr., 2000; neste capítulo). Portanto, de um modo geral, os Eriophyoidea que infestam as palmeiras nativas da região não vem colonizando as palmeiras introduzidas (com exceção de $R$. johnstoni). Este resultado era esperado, considerando a alta especificidade hospedeira dos ácaros desta superfamília.

No caso de algumas palmeiras amostradas em suas áreas de ocorrência natural e também em áreas onde foram introduzidas, Eriophyoidea foram encontradas apenas em suas regiões de ocorrência natural: Coccothrinax argentata (Jacq) L. H. Bailey; Sabal sp. e $T$. radiata Lodd. (Tabela 1 ).

Até o momento, apenas uma espécie do gênero Aceria Keifer, A. guerreronis (Keifer, 1965; Amrine Jr. \& de Lillo, 2003) havia sido relatada associada a Arecaceae. Três novas espécies deste gênero foram encontradas sobre folhas, frutos e brotos terminais das palmeiras. A. biornata, assemelha-se bastante a A. guerreronis e, assim como esta, foi encontrada em brotos terminais.

Um grande número de espécies de Eriophyoidea foi encontrado em algumas palmeiras, destacando-se: B. setosa de Pariquera-Açu, SP, em que foram coletados representantes de cinco espécies diferentes. Diferentes espécies de Eriophyoidea foram coletadas em diferentes partes de um mesmo hospedeiro (Tabela 1). 
A. guerreronis não foi encontrada em nenhuma das 191 palmeiras espécies de palmeiras amostradas, nem mesmo em $L$. weddellianum e $S$. romanzoffiana, palmeiras sobre as quais o ácaro havia sido relatado previamente por outros autores. É possível que estas palmeiras sejam hospedeiras de A. guerreronis em outros períodos do ano, nestas mesmas áreas de coleta, ou em outras áreas de ocorrência natural destas palmeiras. Portanto, é desejável prosseguir este levantamento, em outros pontos da área de ocorrência natural destas palmeiras. Por outro lado, é possível também que estas palmeiras realmente não sejam hospedeiras de A. guerreronis em suas áreas de ocorrência natural. É concebível que a infestação de A. guerreronis em L. weddellianum observada por Flechtmann (1989) se refira a um evento casual, que possa ocorrer sob condições especiais, como por exemplo quando $L$. weddellianum é retirado de seu ambiente natural e posto próximo ou em contato com coqueiros infestados. Neste caso, A. guerreronis poderia estar infestando estas palmeiras ornamentais apenas em condições artificiais de viveiros, não havendo uma estreita associação entre elas e o ácaro do coqueiro. Aceria guerreronis poderia estar se comportando como uma espécie fitófaga: a) "oportunista”, capaz de se desenvolver em novos hospedeiros quando estes representem recursos abundantes e sobre os quais inimigos naturais não estão presentes; b) de baixa especificidade, podendo infestar hospedeiros de gêneros distintos; e c) "agressiva”, atingindo altos níveis populacionais e causando sérios danos a estes novos hospedeiros. Este comportamento poderia ser considerado raro entre os Eriophyoidea, pois a grande maioria destes infestam hospedeiros pertencentes a um único gênero de plantas (Oldfield, 1996). Ao mesmo tempo, seria compatível como o histórico de A. guerreronis como espécie invasora, bastante agressiva quando ocupa novos nichos (novas áreas ou novos hospedeiros), o que reforçaria a hipótese de que o coqueiro não é seu hospedeiro original, pois assim como estaria adotando $L$. weddellianum e $S$. romanzoffiana como novos hospedeiros, poderia, anteriormente, também ter se adaptado ao coqueiro. 


\subsection{Conclusões}

* Ocorrem 38 espécies de Eriophyoidea, pertencentes a 14 gêneros, associados a 34 das espécies de palmeiras amostradas.

* A. guerreronis não utiliza como hospedeira nenhuma das 191 palmeiras amostradas, nos seus respectivos locais de coleta, e nos períodos do ano em que este levantamento foi realizado.

* Ácaros Eriophyoidea associados às palmeiras nativas da região de Campinas e Piracicaba, não utilizam como hospedeiras a maior parte das palmeiras introduzidas naquela região.

* Há 26 novos táxons (3 gêneros e 26 espécies) de Eriophyoidea associados a palmeiras nas Américas; 18 espécies de palmeiras são novas hospedeiras para espécies já conhecidas; duas espécies de Eriophyoidea ocorrem em países/estados onde não haviam sido coletadas. 


\section{NOVOS GÊNEROS E ESPÉCIES DE ÁCAROS ERIOPHYIDAE E PHYTOPTIDAE (PROSTIGMATA: ERIOPHYOIDEA) ASSOCIADOS A PALMEIRAS (ARECACEAE)}

\section{Resumo}

Foram identificados três novos gêneros e 17 novas espécies de Eriophyidae e Phytoptidae em palmeiras. Dois novos gêneros e 14 novas espécies pertencem a Eriophyidae: Aceria biornata Navia \& Flechtmann, 2002 de Acrocomia aculeata (Jacq.) Lodd.; Aceria gymnoscuta Navia \& Flechtmann, 2002, de Syagrus flexuosa (Mart.) Becc. e Syagrus cocoides Mart.; Aceria translinea Navia \& Flechtmann, 2002 de Syagrus romanzoffiana (Cham.) Glass. e Attalea dubia (Mart.) Burret; Adenoptus migeoni Navia \& Flechtmann, 2003 de Chamaerops humilis L.; Glabrisceles Navia \& Flechtmann, 2002, espécie tipo G. euterpis Navia \& Flechtmann, 2002 de Euterpe edulis Mart.; Nasuchus Navia \& Flechtmann, 2002, espécie tipo N. pindobates Navia \& Flechtmann, 2002 de Geonoma gamiovora Barb. Rodr.; Notostrix acuminata Navia \& Flechtmann, 2003 de A. acuminata e Syagrus oleracea (Mart.) Becc.; Notostrix fissipes Navia \& Flechtmann, 2003 de A. dubia; Notostrix longiseta Navia \& Flechtmann, 2003 de Butia archeri (Glass.) Glass.; Notostrix miniseta Navia \& Flechtmann, 2003 de Bactris vulgaris Barb. Rodr.; Notostrix trifida Navia \& Flechtmann, 2003 de Lytocaryum hoehnei (Burret) Tol.; Notostrix vasquezae Navia \& Flechtmann, 2003 de Sabal sp.; Proartacris longior Navia \& Flechtmann, 2002 de Butia eriospatha (Mart. ex Drude) Becc.; Schizacea geonomae Navia \& Flechtmann, 2002 de Geonoma sp.. Um novo gênero e três novas espécies pertencem a Phytoptidae: Acathrix lobata Navia \& 
Flechtmann, 2002 de Geonoma schottiana Mart. e Geonoma sp.; Palmiphytoptus Navia \& Flechtmann, 2002, espécie tipo P. oculatus Navia \& Flechtmann, 2002 de Astrocaryum aculeatissimum (Schott) Burret e Propilus pellitus Navia \& Flechtmann, 2002 de L. hoehnei. As diagnoses, características morfológicas, plantas hospedeiras, localidades e material tipo destes gêneros e espécies são apresentados neste capítulo.

\section{NEW GENERA AND SPECIES OF ERIOPHYIDAE AND PHYTOPTIDAE MITES (PROSTIGMATA: ERIOPHYOIDEA) ASSOCIATED WITH PALM TREES (ARECACEAE)}

\section{Summary}

Three new genera and 17 new species of Eriophyidae and Phytoptidae mites were described from palm trees. Two of the new genera and fourteen of the new species belong to the Eriophyidae: Aceria biornata Navia \& Flechtmann, 2002 from Acrocomia aculeata (Jacq.) Lodd; Aceria gymnoscuta Navia \& Flechtmann, 2002 from Syagrus flexuosa (Mart.) Becc. and Syagrus cocoides Mart; Aceria translinea Navia \& Flechtmann, 2002 from Syagrus romanzoffiana (Cham.) Glass. and Attalea dubia (Mart.) Burret; Adenoptus migeoni Navia \& Flechtmann, 2003b from Chamaerops humilis L.; Glabrisceles Navia \& Flechtmann, 2002, type species G. euterpis Navia \& Flechtmann, 2002 from Euterpe edulis Mart.; Nasuchus Navia \& Flechtmann, 2002, type species N. pindobates Navia \& Flechtmann, 2002 from Geonoma gamiovora Barb. Rodr.; Notostrix acuminata Navia \& Flechtmann, 2003 from A. acuminata and Syagrus oleracea (Mart.) Becc.; Notostrix fissipes Navia \& Flechtmann, 2003 from A. dubia; Notostrix longiseta Navia \& Flechtmann, 2003 from Butia archeri (Glass.) Glass.; Notostrix miniseta Navia \& Flechtmann, 2003 from Bactris vulgaris Barb. Rodr.; Notostrix trifida Navia \& Flechtmann, 2003 from Lytocaryum hoehnei (Burret) Tol.; Notostrix vasquezae Navia \& Flechtmann, 2003 from Sabal sp.; Proartacris longior Navia \& Flechtmann, 2002 from Butia eriospatha (Mart. ex Drude) Becc.; Schizacea geonomae Navia \& Flechtmann, 2002 from Geonoma sp.. A new genus and three new 
species belong to the Phytoptidae: Acathrix lobata Navia \& Flechtmann, 2002 from Geonoma schottiana Mart. and Geonoma sp.; Palmiphytoptus Navia \& Flechtmann, 2002, type species P. oculatus Navia \& Flechtmann, 2002 from Astrocaryum aculeatissimum (Schott) Burret and Propilus pellitus Navia \& Flechtmann, 2002 from L. hoehnei. Diagnoses, morphological characteristics, type hosts and localities are provided for each taxon.

\subsection{Introdução}

Muito pouco se conhece sobre os ácaros eriofiídeos no mundo. Estima-se que apenas cerca de 5\% dos táxons de Eriophyoidea tenham sido descritos até o momento e algumas regiões do mundo permanecem virtualmente intocadas em relação ao levantamento de ácaros desta superfamília (Amrine \& Stasny, 1994). Pode-se considerar que as regiões Neotropicais são muito pouco conhecidas em relação à fauna de Eriophyoidea. Apesar de que um grande número de trabalhos sobre a fauna de Eriophyoidea vir sendo publicado nos últimos anos, especialmente do Brasil, os ácaros associados a diversos grupos de plantas, inclusive algumas de importância econômica, são pouco conhecidas e alguns habitats ainda não foram explorados.

As palmeiras representam um grupo de plantas de grande importância econômica e social nas regiões tropicais e subtropicais. Algumas espécies são cultivadas em larga escala e suas áreas de produção vêm se expandindo a cada dia. Outras espécies, ainda não cultivadas, apresentam grande potencial agrícola, são exploradas através de extrativismo, ou são amplamente utilizadas como ornamentais (Lorenzi, 1996).

Diversas espécies de ácaros Eriophyoidea atingem status de pragas em agroecossitemas (Lindquist et al., 1996). O conhecimento da fauna de Eriophyoidea, bem como de outras famílias de ácaros fitófagos, associada a palmeiras é importante por fornecer subsídios ao reconhecimento destes ácaros em cultivos comerciais de arecáceas e, desta forma, facilitar o entendimento de possíveis alterações futuras da importância destes artrópodos em agroecossitemas. 
Atualmente são conhecidas cerca de 3500 espécies de palmeiras (Lorenzi, 1996). Até o início do desenvolvimento deste projeto de tese, em 2000, 40 espécies de eriofíídeos eram conhecidas associadas às palmeiras por todo o mundo, associados a apenas 35 espécies de palmeiras (Amrine Jr. \& de Lillo, 2003; Capítulos 3 e 5). Tem sido estimado que mais de dois terços das espécies de palmeiras do mundo ocorrem em florestas tropicais úmidas (Jones, 1995), áreas praticamente não exploradas em relação à fauna de Eriophyoidea (Amrine Jr. \& de Lillo, 2003). Portanto, considera-se importante conhecer mais sobre a fauna destes ácaros associada às palmeiras por todo o mundo, especialmente nas regiões tropicais.

Este trabalho teve como objetivo contribuir para o conhecimento dos ácaros Eriophyoidea associados às palmeiras, especialmente do Brasil e do México. Neste capítulo encontram-se as diagnoses, características morfológicas, hospedeiros, material e localidades tipo de gêneros e espécies identificados como novos táxons de Eriophyoidea associados às arecáceas, coletados (em sua maioria) nos levantamentos realizados dentro deste projeto (Capítulo 3).

\subsection{Material e Métodos}

Os ácaros foram montados em preparações microscópicas em meio de Berlese modificado, examinados em microscópio de contraste de fase (Leitz Dialux 20), e desenhados com o auxílio de uma câmara clara utilizando-se a objetiva com aumento de 100x. As medidas foram tomadas utilizando-se uma ocular micrométrica também com a objetiva de 100x.

Todas as medidas são dadas em micrômetros $(\mu \mathrm{m})$. Para as fêmeas, cada medida do holótipo precede a amplitude de variação das medidas dos parátipos. Algumas medidas dos holótipos podem não ter sido tomadas devido à posição de montagem dos mesmos. A contagem dos anéis opistossomais ventrais inicia a partir do primeiro anel após a borda posterior da genitália. A contagem dos anéis opistossomais dorsais inicia a 
partir da margem posterior do escudo dorsal. O comprimento das pernas foi medido da base do trocânter até a extremidade do tarso (não incluindo o empódio).

Este trabalho foi realizado com a colaboração do Dr. Carlos H. W. Flechtmann, pesquisador CNPq, Setor de Zoologia Agrícola, Escola Superior de Agricultura Luiz de Queiroz, Universidade de São Paulo, Piracicaba, SP, Brasil.

\subsection{Resultados e Discussão}

Foram descritos três gêneros novos e 17 espécies novas de Eriophyoidea. As diagnoses; características morfológicas das fêmeas, machos e imaturos (quando disponíveis); relação com as plantas hospedeiras; localidade e material tipo dos gêneros e espécies identificados como novos encontram-se a seguir.

\section{ERIOPHYIDAE}

\section{Aceria biornata Navia \& Flechtmann, 2002}

(Figura 1)

DIAGNOSE - Uma Aceria com lobo frontal curto, arredondado, base larga e flexível; empódio com 8 raios pareados e um apical não pareado; genitália da fêmea com grânulos na região anterior e linhas longitudinais na metade posterior.

OBSERVAÇÃO - Esta é a segunda espécie de Aceria (Eriophyinae, Aceriini) de Arecaceae a ser descrita. Aceria biornata Navia \& Flechtmann, 2002 difere de Aceria gymnoscuta Navia \& Flechtmann, 2002, apresentada a seguir, pelo lobo frontal curto e arredondado (subtriangular e bem desenvolvido em A. gymnoscuta), pelas linhas longitudinais e transversais do escudo dorsal (centralmente liso em A. gymnoscuta) e 

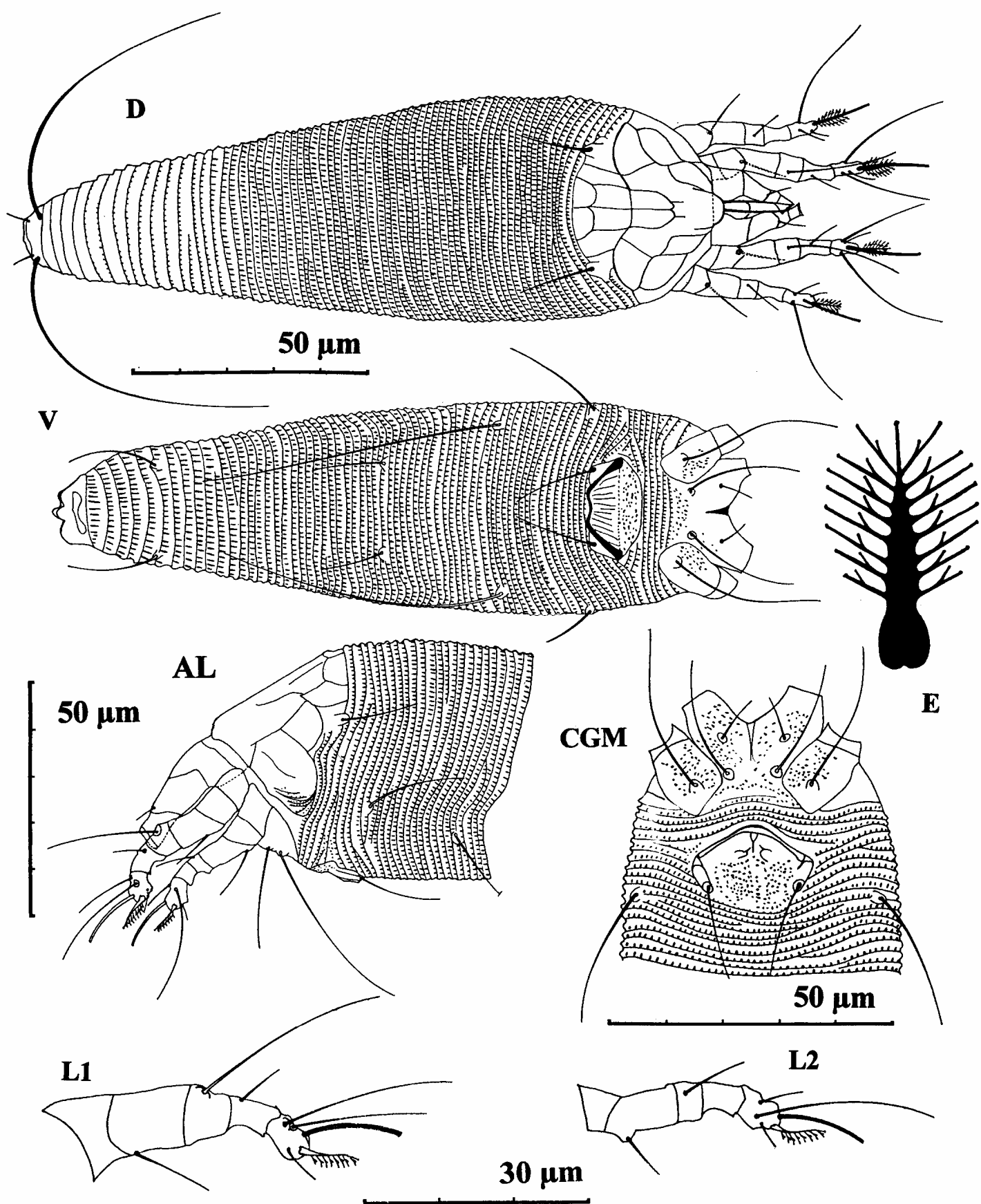

Figura 1 - Aceria biornata Navia \& Flechtmann, 2002 - D- vista dorsal da fêmea; Vvista ventral da fêmea; L- vista ântero-lateral da fêmea; CGM - região coxigenital do macho; L1- Pernas I; L2 - Pernas II; E- empódio. (E aumentado) 
pela presença da seta do genu (l") das pernas II e seta acessória $\left(h_{1}\right)$ (ausentes em A. gymnoscuta); de A. guerreronis Keifer, 1965 e A. gymnoscuta pelos empódios com 8 pares de raios e um raio apical não pareado (sem raio apical não pareado em $A$. guerreronis e em A. gymnoscuta); e de A. guerreronis pela genitália da fêmea com grânulos na região anterior (sem grânulos em A. guerreronis).

FÊMEA - $(\mathrm{n}=10)$. Comprimento do corpo 126 (119-202), largura 39 (36-58), vermiforme, esbranquiçadas. Gnatossoma curvado v entralmente em um ângulo obtuso, com 26 (22-27) de comprimento. Seta antapical (d) com 4 (4-5) de comprimento; seta basal (ep) com 2 de comprimento; quelíceras com 20 (19-22) de comprimento; estiletes orais com 14 (13-16) de comprimento. Escudo dorsal com linhas medianas e admedianas nos 3/4 posteriores de sua extensão, ligadas por linhas transversais, formando células; linhas curvas e diagonais formando células laterais no escudo; linhas diagonais unindo as linhas laterais às células centrais; com 27 (26-31) de comprimento, 33 (31-44) de largura, subcircular; lobo frontal arredondado e com a base larga e flexível, com 3 (3-4) de comprimento. Seta escapular do escudo dorsal (sc) com 13 (11-14) de comprimento, direcionadas para trás, sobre tubérculos bem desenvolvidos, distanciados em 19 (18-25). Pernas com todas as setas usuais presentes. Pernas I com 26 (24-30) de comprimento; fêmur com 10 (8-10) de comprimento; seta femural (bv) com 7 (7-11) de comprimento; genu com 4 (4-5) de comprimento; seta do genu (l') com 16 (16-22) de comprimento; tíbia com 6 (5-6) de comprimento; seta da tíbia (l') com 5 de comprimento; tarso com 5 (5-7) de comprimento; seta lateral (ft”) com 22 (18-22) de comprimento; seta dorsal ( $\left.f t^{\prime}\right)$ com 15 (14-17) de comprimento; seta unguinal ( $\left.u^{\prime}\right)$ com 4 de comprimento; solenídio com 11 de comprimento, empódio 7 (7-8) de comprimento, com 8 raios pareados e um não pareado. Pernas II com 23 (23-26) de comprimento; fêmur com 9 (7-9) de comprimento; seta femural (bv) com 9 (8-10) de comprimento; genu com 4 de comprimento; seta do genu (l") com 7 (7-9) de comprimento; tíbia com 4 (4-5) de comprimento; tarso com 5 (5-7) de comprimento; seta lateral (ft") com 21 (1922) de comprimento; seta dorsal ( $\left.f t^{\prime}\right)$ com 4 (4-6) de comprimento, seta unguinal ( $\left.u^{\prime}\right)$ com 4 (3-4) de comprimento, solenídio com 10 (9-11); empódio com 7 (6-7) de 
comprimento, 7 (7-8) raios mais um terminal não pareado. Setas coxais $1(1 b)$ separadas entre si por 10 (9-11), com 7 de comprimento; setas coxais 2 (1a) separadas por 7 (6-8), com 18 (15-21) de comprimento; setas coxais 3 (2a) separadas por 18 (18-20), com 29 (26-36) de comprimento. Coxas com grânulos. Linha esternal com 4 (4-6) de comprimento. Região coxiesternal com 5 (4-6) anéis, microtuberculados. Epigínio com 19 (18-20) de largura, com 10 (10-12) de comprimento, com 14 (14-17) linhas na região posterior; região anterior granular; seta genital (3a) com 12 (11-18) de comprimento.Opistossoma subigual dorsoventralmente. Microtubérculos um pouco mais alongados dorsalmente que ventralmente. Dorsalmente os microtubérculos tornamse gradualmente menores e arredondados nos 2/3 posteriores do opistossoma e desaparecem nos últimos 4 anéis, os quais são lisos. $\mathrm{Na}$ região ventral os microtubérculos tornam-se gradualmente mais alongado nos últimos 5 anéis. Seta lateral $\left(c_{2}\right)$ com 19 (17-19) de comprimento, no anel 4 (3-5); setas ventrais 1 (d) no anel 17-18 (15-19), distanciadas por 30 (28-33) e por 37 (35-42) microtubérculos, com 49 (48-51) de comprimento; setas ventrais 2 (e) no anel 33-34 (30-35), distanciadas por 16 (16-19) e por 17 (16-24) microtubérculos, com 12 (11-13) de comprimento; setas ventrais $3(f)$ no anel 58-59 (55-63), separadas por 18 (16-19) e por 19 (18-25) microtubérculos, com 23 (20-27) de comprimento. Total de anéis dorsais 65 (63-72), total de anéis ventrais 63 (60-67). Seta caudal $\left(h_{2}\right)$ com 57 (53-61) de comprimento; seta acessória $\left(h_{1}\right)$ com 4 (34) de comprimento.

MACHO - $(n=5)$. Menor que a fêmea, com 113-189 de comprimento e com 3149 de largura. Gnatossoma - com 23-28 de comprimento. Seta antapical (d) com 4-5 de comprimento; ep com 2 de comprimento; quelíceras com 22-24 de comprimento; estiletes orais com 14-18 de comprimento; curvados ventralmente em um ângulo obtuso. Escudo dorsal como na fêmea, 26-29 de comprimento, 27-44 de largura; sc com 13-14 de comprimento sobre tubérculos separados entre si por 17-18. Pernas como na fêmea. Pernas I com 25-27 de comprimento; fêmur com 8-9 de comprimento, bv com 9-10 de comprimento; genu com 4 de comprimento, l" com 19-20 de comprimento; tíbia com 56 de comprimento, l' com 4-5 de comprimento; tarso com 5-7 de comprimento, $f t$ " com 18-20 de comprimento, $f t^{\prime}$ com 14-17 de comprimento, $u$ ' com 4 de comprimento, 
solenídio com 11 de comprimento; empódio com 7 de comprimento, 7-8 raios mais um não pareado. Pernas II com 20-22 de comprimento; fêmur com 7-8 de comprimento, $b v$ com 9-11 de comprimento; genu com 4 de comprimento, l" com 7-10 de comprimento; tíbia com 5 (4-5) de comprimento; tarso com 5 de comprimento, ft" com 20 (19-22) de comprimento, $\mathrm{ft}$ ' com 5 de comprimento, $u$ ' com 4 de comprimento, solenídio com 10 (9-10) de comprimento, empódio com 7 de comprimento, 7 raios pareados mais um raio não pareado. Coxas: setas $1 b$ distanciadas em 9 (8-9), com 6-8 de comprimento; setas $1 a$ distanciadas em 6, com 17-19 de comprimento; setas $2 a$ distanciadas em 16-18, com 26-31 de comprimento. Coxas com grânulos. Linha esternal com 4-5 de comprimento. Região coxiesternal com 5-6 anéis, microtuberculados. Genitália com 18 de largura e 14-18 de comprimento, com grânulos; papilas pronunciadas e com extremidade pontuda, como no desenho; seta $3 a$ com 11-14 de comprimento. Opistossoma como na fêmea, seta $c_{2}$ com 18-21 de comprimento, sobre o anel 2-5; setas $d$ sobre o anel 9-12, separadas por 25-27 e por 35-37 microtubérculos, com 42-47 de comprimento; setas e sobre o anel 24-28, separadas por 14 e por 17-20 microtubérculos, com 12-14 de comprimento; setas $f$ sobre o anel 49-59, distanciadas por 13-16 e por 18-21 microtubérculos, com 20-25 de comprimento. Total de anéis dorsais 61-64, total de anéis ventrais 54-63. Seta caudal $h_{2}$ com 48-61 de comprimento, $h_{1}$ com 4 de comprimento.

MATERIAL TIPO - Holótipo fêmea, 8 parátipos fêmeas, 7 parátipos machos em 6 preparações microscópicas, 11 novembro 2000; 05 parátipos fêmeas e 10 parátipos machos em 5 preparações microscópicas, 11 julho 2001, de Acrocomia aculeata (Jacq.) Lodd. (Arecaceae), "Estação Ecológica de Ibicatu", Piracicaba, São Paulo, Brasil (22 46' 43" S, 47 49' 32" W), coletados por D. Navia e L. V. F. da Silva, depositados na Coleção Acarológica do Setor de Zoologia, Departamento de Entomologia, Fitopatologia e Zoologia Agrícola da ESALQ-USP, Piracicaba, SP, Brasil.

RELAÇÃO COM HOSPEDEIRO - este ácaro vagrante foi coletado de brotos terminais de A. aculeata, sem causar danos aparentes. 
ETIMOLOGIA - A designação específica biornata é composta pelo latim bi (duas vezes) e pelo latim ornatus (decorado), referindo-se à genitália da fêmea com uma área granular na região anterior e com linhas longitudinais na região posterior.

\section{Aceria gymnoscuta Navia \& Flechtmann, 2002}

(Figura 2)

DIAGNOSE - Uma Aceria com lobo frontal subtriangular, que apresenta a base flexível; sem linhas longitudinais no escudo dorsal; empódio com 5-6 raios; seta do genu (l”) das pernas II e seta acessória $\left(h_{1}\right)$ ausentes e fêmea com as coxas fundidas.

OBSERVAÇÃO - Esta é a terceira espécie do gênero Aceria (Eriophyinae, Aceriini) citada em Arecaceae a ser descrita. Difere de A. guerreronis e de A. biornata pelo lobo frontal subtriangular e bem desenvolvido (curto e arredondado em $A$. guerreronis; curto e arredondado em A. gymnoscuta); escudo dorsal centralmente não ornamentado (liso) (com linhas longitudinais fortes em A. guerreronis e em $A$. biornata); pelos pequenos microtubérculos na margem posterior dos anéis opistossomais (proeminentes em A. guerreronis e em A. biornata); pela ausência da seta do genu (l') nas pernas II e da seta acessória $\left(h_{1}\right)$ (presentes em A. guerreronis e em A. biornata); pela ausência da linha esternal e pelas coxas fundidas na fêmea (coxas completamente separadas em A. guerreronis e em A. biornata).

FÊMEA - (n=10). Comprimento do corpo 189 (178-222), largura 51 (48-54), vermiforme, esbranquiçada. Gnatossoma curvado ventralmente em um ângulo obtuso, com 17 (17-21) de comprimento. Seta antapical (d) com 6 (5-7) de comprimento; seta basal (ep) com 3 de comprimento; quelíceras com 15 (14-18) de comprimento; estiletes orais com 11 (8-11) de comprimento. Escudo dorsal com uma linha periférica curva, paralela à margem do escudo; um par de linhas retas curtas, as quais se estendem dos tubérculos das setas do escudo para fora e para frente; e uma linha arqueada entre os 


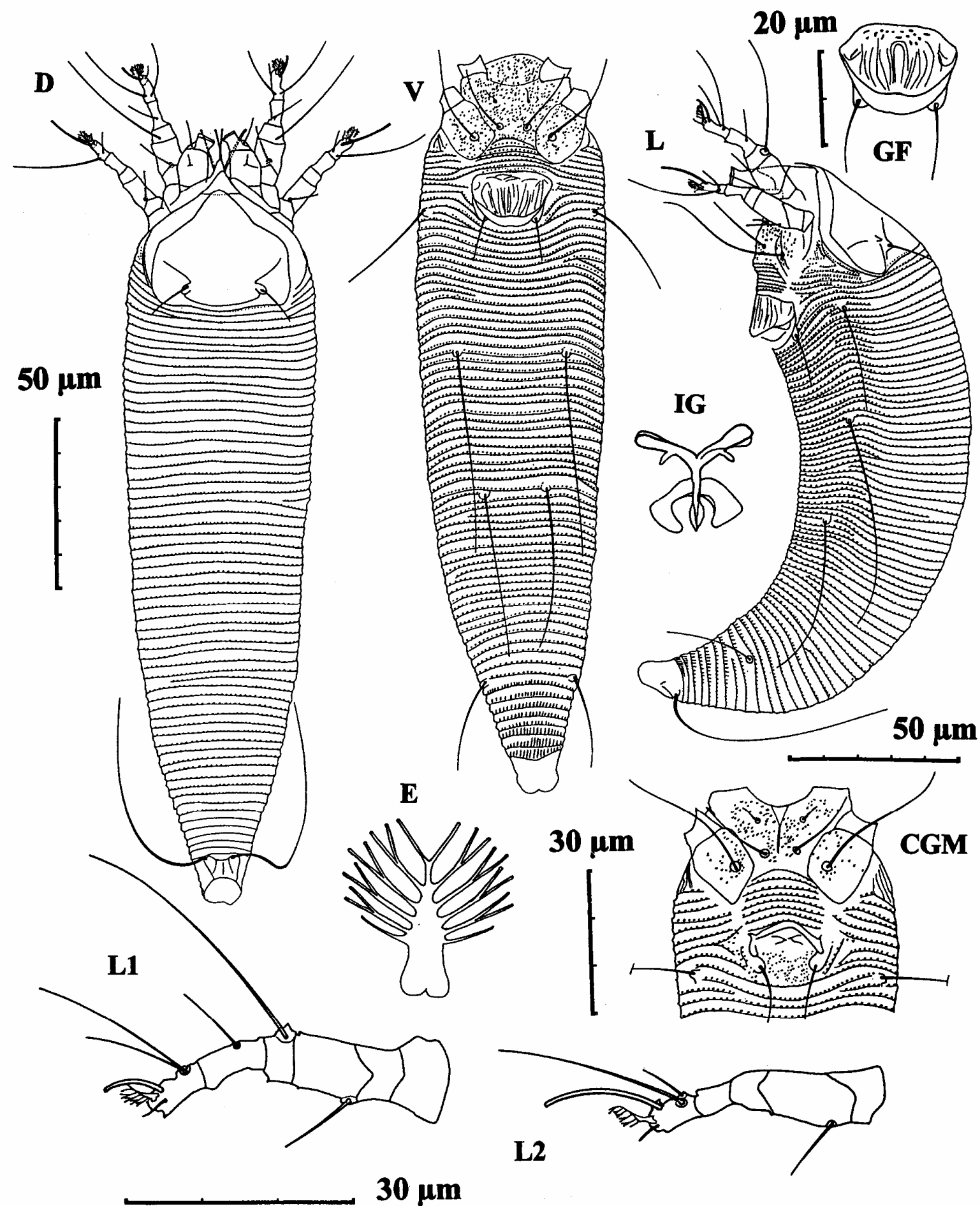

Figura 2 - Aceria gymnoscuta Navia \& Flechtmann, 2002- D- vista dorsal da fêmea; V- vista ventral da fêmea; L- vista lateral da fêmea; CGM- região coxigenital do macho; L1- Pernas I; L2- Pernas II; E- empódio. (E aumentado) 
tubérculos, curvada posteriormente; escudo liso em sua área central; com 37 (37-40) de comprimento e 42 (41-46) de largura, subtriangular, com ângulos posteriores arredondados; lobo frontal subtriangular, apicalmente arredondado, com a base larga e flexível, com 7 (6-8) de comprimento. Setas escapulares do escudo dorsal (SC) com 11(11-13) de comprimento, direcionadas divergentemente para trás, sobre tubérculos bem desenvolvidos, afastados em 18 (16-18). Pernas sem a seta do genu (l”) das pernas II. Pernas I com 30 (29-31) de comprimento; fêmur com 9 (9-10) de comprimento; seta femural (bv) com 11 (9-11) de comprimento; genu com 4 de comprimento; seta do genu (l”) com 32 (27-32) de comprimento; tíbia com 7 (6-7) de comprimento; seta da tíbia (l’) com 8 (7-9) de comprimento; tarso com 7 (6-8) de comprimento; seta lateral ( $f t$ ”) com 19 (19-22) de comprimento; seta dorsal ( $\left.f t^{\prime}\right)$ com 11 (11-15) de comprimento; seta unguinal ( $u^{\prime}$ ) com 3 (3-4) de comprimento; solenídio com 6 (5-7) de comprimento, empódio com 4 (4-5) de comprimento, com 6 raios. Pernas II com 27 (26-27) de comprimento; fêmur com 8 (8-10) de comprimento; seta femural (bv) com 7 (7-8) de comprimento; genu com 4 de comprimento; tíbia com 6 (5-6) de comprimento; tarso com 6 (5-7) de comprimento; seta lateral ( $f$ ") com 23 (21-24) de comprimento; seta dorsal ( $f t^{\prime}$ ) com 4 (4-6) de comprimento, seta unguinal (u’) com 3 (3-4) de comprimento, solenídio com 12 (11-12); empódio com 5 (4-5) de comprimento, com 5 (5-6) raios. Setas coxais 1 (1b) separadas por 9 (9-10), com 4 (4-5) de comprimento; setas coxais 2 (1a) separadas por 7 (6-8), com 20 (18-20) de comprimento; setas coxais 3 (2a) separadas por 19 (18-22), com 33 (33-37) de comprimento. Coxas com grânulos. Linha esternal ausente, coxas 1 fundidas. Região coxiesternal com 7 (6-8) anéis, microtuberculados. Epigínio com 22 (20-22) de largura, com 15 (13-16) de comprimento, apresentando 16 (16-20) linhas longitudinais; margem anterior com grânulos esparsos ou linhas transversais; seta genital (3a) com 12 (12-15) de comprimento. Opistossoma uniformemente arqueado, subigual dorsoventralmente. Pequenos microtubérculos sobre as margens dos anéis dorsais, exceto nos últimos 6-7 anéis caudais, os quais são lisos; microtubérculos ventrais um pouco maiores que os dorsais, os quais tornam-se alongados nos últimos 7 (7-8) anéis. Seta lateral $\left(c_{2}\right)$ com 25 (25-29) de comprimento, sobre o anel 2 (2-3); setas ventrais $1(d)$ sobre o anel 17-18 
(16-20), separadas por 28 (28-32) e por 30 (29-37) microtubérculos, 51 (51-59) de comprimento; setas ventrais 2 (e) sobre o anel 33-34 (32-36), separadas por 16 (16-19) e por 15 (14-18) microtubérculos, com 46 (44-49) de comprimento; setas ventrais $3(f)$ sobre o anel 55-56 (54-59), separadas por 22 (18-25) e por 26 (22-29) microtubérculos, com 23 (23-26) de comprimento. Total de anéis dorsais 61 (61-71), total de anéis ventrais 63 (62-67). Seta caudal $\left(h_{2}\right)$ com 53 (53-61) de comprimento; seta acessória $\left(h_{1}\right)$ ausente.

MACHO - $(n=5)$. Menor que a fêmea, com 151-160 de comprimento e 39-44 de largura. Gnatossoma - com 16-18 de comprimento. Seta antapical $(d)$ com 5-6 de comprimento; ep com 2-3 de comprimento; quelíceras com 13-15 de comprimento; estiletes orais com 11 de comprimento; curvados ventralmente em um ângulo obtuso. Escudo dorsal como na fêmea, com 28-31 de comprimento e 37-40 de largura; setas SC com 10-11 de comprimento, sobre tubérculos distanciados entre si por 13-15. Pernas como na fêmea. Pernas I com 24-26 de comprimento; fêmur com 7-8 de comprimento, seta $b v$ com 6-7 de comprimento; genu com 4 de comprimento, seta l" com 21-25 de comprimento; tíbia com 5- 6 de comprimento, seta l' com 4-5 de comprimento; tarso com 4-6 de comprimento, seta $\mathrm{ft}^{\prime}$ com 8-11 de comprimento, seta $f t^{\prime \prime}$ com 14-17 de comprimento, seta $u^{\prime}$ com 2-3 de comprimento, solenídio com 5-6 de comprimento; empódio com 4 de comprimento e com 5 raios. Pernas II com 23-24 de comprimento; fêmur com 7-8 de comprimento, bv com 5-6 de comprimento; genu com 3-4 de comprimento; tíbia com 4-5 de comprimento; tarso com 5 de comprimento, ft' com 3-4 de comprimento, $f t^{\prime \prime}$ com 16-18 de comprimento, $u^{\prime}$ com 2 de comprimento, solenídio com 10-11 de comprimento, empódio com 4 de comprimento e com 5 raios. Coxas: setas $1 b$ separadas por 8-9, com 4-5 de comprimento; setas $1 a$ separadas por 4-6, com 16-18 de comprimento; setas $2 a$ separadas por 16-18, com 26-30 de comprimento. Coxas com grânulos. Linha esternal com 6-8 de comprimento. Região coxiesternal com 8-9 anéis, microtuberculados. Genitália com 14-15 de largura e 11-13 de comprimento, grânulos entre os tubérculos 3a, como no desenho; seta 3a com 9-11 de comprimento. Opistossoma como na fêmea, $c_{2}$ com 21-26 de comprimento, sobre o anel 1-3; setas $d$ 
sobre o anel 12-14, separadas por $22-23$ e por 20-23 microtubérculos, com 44-48 de comprimento; setas e sobre o anel 24-27, separadas por 12-14 e por 9-12 microtubérculos, com 29-32 de comprimento; setas $f$ sobre o anel 44-48, separadas por 18-19 e por 18-24 microtubérculos, com 17-19 de comprimento. Total de anéis dorsais 60-62, total de anéis ventrais 51-56. Seta caudal $h_{2}$ com 37-44 de comprimento, $h_{1}$ ausente.

MATERIAL TIPO - Holótipo fêmea, 51 parátipos fêmeas, 8 parátipos machos em 12 preparações microscópicas, 5 de setembro 2000 e 12 de janeiro de 2001, de Syagrus flexuosa (Mart.) Becc. (Arecaceae), "Reserva Estadual da Serra do Japi", Jundiaí, São Paulo, Brasil (23 $\left.13^{\prime} 18^{\prime \prime} \mathrm{S}, 4^{\circ} 55^{\prime} 16^{\prime \prime} \mathrm{W}\right)$ e 12 parátipos fêmeas, 02 parátipos machos em duas preparações microscópicas, 19 de maio de 2000, de Syagrus cocoides Mart. (Arecaceae), "Fazenda Santa Elisa, Instituto Agronômico de Campinas", Campinas-SP, Brasil ( $\left.24^{\circ} 36^{\prime} 41^{\prime \prime} \mathrm{S}, 47^{\circ} 53^{\prime} 23^{\prime \prime} \mathrm{W}\right)$, coletados por D. Navia e L. V. F. da Silva, na Coleção Acarológica do Setor de Zoologia, Departamento de Entomologia, Fitopatologia e Zoologia Agrícola da ESALQ-USP, Piracicaba, SP, Brasil.

RELAÇÃO COM HOSPEDEIRO - este ácaro vagrante foi coletado na superfície inferior de folhas de S. flexuosa e de frutos de S. cocoides, sem causar danos aparentes.

ETIMOLOGIA -A designação específica gymnoscuta é composta pelo grego gymno (nu) e pelo latim scutum (escudo), referindo-se ao escudo dorsal liso.

\section{Aceria translinea Navia \& Flechtmann, 2002}

(Figura 3)

DIAGNOSE - Uma Aceria que se assemelha à protogina de Cisaberoptus como no desenho em Amrine (1996). As pernas são robustas, o opistossoma é levemente e 


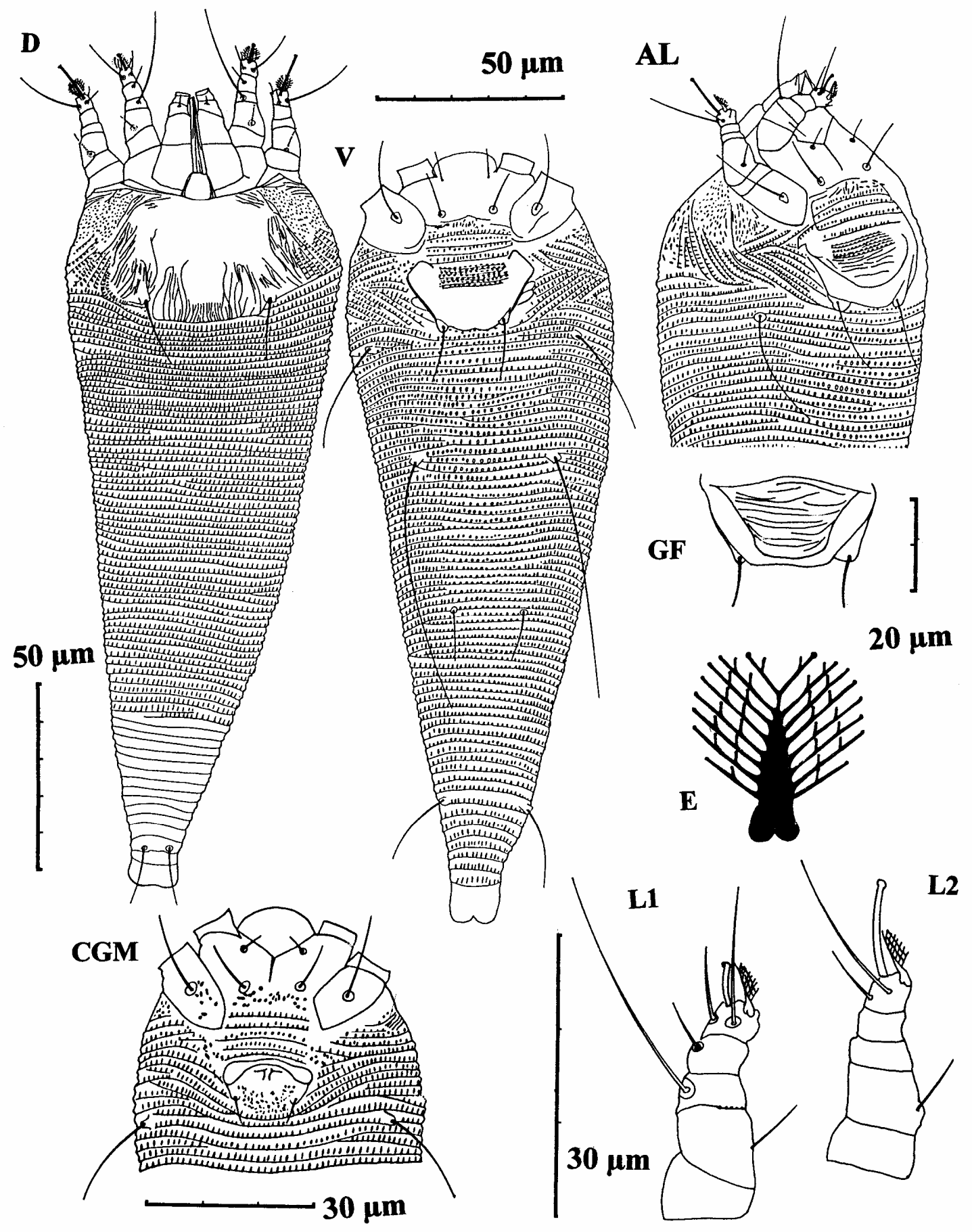

Figura 3 - Aceria translinea Navia \& Flechtmann, 2002- D- vista dorsal da fêmea; Vvista ventral da fêmea; L- vista ântero-lateral da fêmea; CGM- região coxigenital do macho; GF- epigínio de fêmeas de espécimes coletados de Syagrus romanzoffiana; L1- Pernas I; L2- Pernas II; E-empódio. (E aumentado) 
fusiforme; epigínio com anéis microtuberculados na região anterior ou com linhas transversais; seta do genu (l”) das pernas II e seta acessória $\left(h_{1}\right)$ ausentes.

OBSERVAÇÃO - Esta é a quarta espécie do gênero Aceria (Eriophyinae, Aceriini) citada em hospedeiros da família Arecaceae a ser descrita. Difere de A. gymnoscuta e de A. biornata pela ausência de lobo frontal; de todas as demais espécies pela ornamentação do escudo dorsal que se assemelha a da protogina de Cisaberoptus; de A. guerreronis e de A. biornata sp. n. pela ausência da seta do genu (l”) das pernas II e da seta acessória $\left(h_{1}\right)$; de A. biornata pela ausência do raio apical não pareado nos empódios e de todas as demais espécies pela genitália da fêmea com anéis microtuberculados ou linhas transversais na região anterior.

FÊMEA - (n=10). Comprimento do corpo 157 (152-178), largura 60 (55-70), levemente fusiforme, esbranquiçadas. Gnatossoma curvado ventralmente em um ângulo obtuso, com 25 (23-27) de comprimento. Seta antapical (d) com 2 (2-3) de comprimento; quelíceras com 23 (23-24) de comprimento; estiletes orais com 12 (11-15) de comprimento. Escudo dorsal subretangular, com grânulos nas áreas anterolaterais; áreas posterolaterais com anéis microtuberculados; linhas sinuosas longitudinais e diagonais nas regiões anteriores, laterais e posteriores internamente às áreas granulosas e com anéis; região central lisa; com 27 (26-29) de comprimento e 57 (54-66) de largura; setas escapulares do escudo dorsal (sc) com 14 (12-16) de comprimento, direcionadas posteriormente, sobre tubérculos bem desenvolvidos, separados por 25 (25-28). Pernas com a seta do genu II (l”) ausente. Pernas I com 19 (19-21) de comprimento; fêmur com 7 (6-7) de comprimento; seta femural (bv) com 4 (4-5) de comprimento; genu com 4 (34) de comprimento; seta do genu (l”) com 23 (19-23) de comprimento; tíbia com 4 de comprimento; seta da tíbia (l') com 3 (3-5) de comprimento; tarso com 4 (4-5) de comprimento; seta lateral ( $\left.f t^{\prime \prime}\right)$ com 12 (10-13) de comprimento; seta dorsal (ft') com 6 (5-6) de comprimento; seta unguinal ( $\left.u^{\prime}\right)$ com 3 (2-3) de comprimento; solenídio com 4 (4-5) de comprimento, empódio com 5 (4-5) de comprimento e com 8 raios. Pernas II com 18 (18-19) de comprimento; fêmur com 7 (6-7) de comprimento; seta femural (bv) 
com 5 (4-5) de comprimento; genu com 3 de comprimento; tíbia com 3 (3-4) de comprimento; tarso com 4 de comprimento; seta lateral (ft”) com 14 (14-16) de comprimento; seta dorsal ( $f t^{\prime}$ ) com 4 de comprimento, seta unguinal ( $u^{\prime}$ ) com 3 de comprimento, solenídio com 9 (9-10) de comprimento; empódio com 5 (4-5) de comprimento e com 8 raios. Setas coxais 1 (1b) separadas por 11 (10-11), com 5 (4-7) de comprimento; setas coxais 2 (1a) separadas por 11 (10-11), com 12 (11-17) de comprimento; setas coxais 3 (2a) separadas por 31 (30-33), com 17 (16-23) de comprimento. Coxas lisas. Linha esternal com 4 (4-6) de comprimento. Região coxiesternal com 4 (4-5) anéis, microtuberculados. Epigínio com 30 (26-30) de largura e 15 (14-15) de comprimento, com 7 (7-8) anéis microtuberculados na região anterior ou linhas transversais esparsas e interrompidas; seta genital (3a) com 16 (11-16) de comprimento. Opistossoma subigual dorsoventralmente. Microtubérculos mais alongados dorsalmente; anéis terminais dorsais lisos. Ventralmente, na área central, os microtubérculos são mais arredondados e tornam-se gradualmente mais alongados nos últimos 6 (6-7) anéis. Seta lateral $\left(c_{2}\right)$ com 24 (22-26) de comprimento, sobre o anel 2 (2-5); setas ventrais $1(d)$ sobre o anel 16-17 (15-18), separadas por 31 (31-35) e por 22 (22-25) microtubérculos, com 55 (44-55) de comprimento; setas ventrais 2 (e) sobre o anel 35-36 (29-36), separadas por 15 (15-18) e por 12 (10-14) microtubérculos, com 12 (11-15) de comprimento; setas ventrais 3 ( $f$ ) sobre o anel 59-60 (52-60), separadas por $18(18-20)$ e por 16 (16-20) microtubérculos, com 17 (16-18) de comprimento. Total de anéis dorsais 71 (67-73), total de anéis ventrais 66 (59-68). Seta caudal $\left(h_{2}\right)$ com 12 (1037) de comprimento; seta acessória $\left(h_{1}\right)$ ausente.

MACHO - $(n=5)$. Menor que a fêmea, com 92-128 de comprimento e 46-55 de largura. Gnatossoma - com 21-23 de comprimento. Seta antapical (d) com 2-4 de comprimento; quelíceras com 15-23 de comprimento; estiletes orais com 9-11 de comprimento; curvados ventralmente em um ângulo obtuso. Escudo dorsal como o da fêmea, com 23-25 de comprimento e 42-50 de largura; setas SC com 9-11 de comprimento, sobre tubérculos separados entre si por 20-21. Pernas como as da fêmea. Pernas I com 17-18 de comprimento; fêmur com 5-6 de comprimento, bv com 3-4 de 
comprimento; genu com 3 de comprimento, l" com 14-18 de comprimento; tíbia com 4 de comprimento, l' com 2-3 de comprimento; tarso com 3-4 de comprimento, ft” com 911 de comprimento, $f t^{\prime}$ com 4 de comprimento, $u^{\prime}$ com 2 de comprimento, solenídio com 4 de comprimento; empódio com 4 de comprimento, 7-8 raios. Pernas II com 14-16 de comprimento; fêmur com 5 de comprimento, $b v$ com 2-3 de comprimento; genu com 2-3 de comprimento; tíbia com 3 de comprimento; tarso com 3-4 de comprimento, ft” com 12 de comprimento, $f t^{\prime}$ com 2-3 de comprimento, $u$ ' com 2 de comprimento, solenídio com 9 de comprimento, empódio com 4 de comprimento e com 7 raios. Coxas: setas $1 b$ separadas por 8-9, com 3-4 de comprimento; setas 1 a separadas por 8-9, com 9-11 de comprimento; setas $2 a$ separadas por 23-24, com 12-19 de comprimento. Coxas com poucos grânulos. Linha esternal com 4 de comprimento. Região coxiesternal com 4 anéis, microtuberculados. Genitália com 13-14 de largura e 10-11 de comprimento, com grânulos esparsos na região posterior, papilas conspícuas direcionadas anteriormente, como no desenho; $3 a$ com 4 de comprimento. Opistossoma como na fêmea, $c_{2}$ com 14-16 de comprimento, sobre o anel 3-4; setas $d$ sobre o anel 9-12, separadas por 27-30 e por 20-24 microtubérculos, com 29-32 de comprimento; setas $e$ sobre o anel 18-24, separadas por 16-17 e por 10-18 microtubérculos, com 4-6 de comprimento; setas $f$ sobre o anel 34-39, separadas por 15-18 e por 15-19 microtubérculos, com 12-14 de comprimento. Total de anéis dorsais 47-51, total de anéis ventrais 41-44. Seta caudal $h_{2}$ com 9-11 de comprimento, $h_{1}$ ausente.

MATERIAL TIPO - Holótipo fêmea, 10 parátipos fêmeas, 7 parátipos machos em 4 preparações microscópicas, 19 de abril de 2000; 6 parátipos fêmeas e 4 parátipos machos em 3 preparações microscópicas, 10 de outubro de 2000, de Attalea dubia (Mart.) Burret (Arecaceae), Pariquera-Açu, São Paulo, Brasil (24 36' 41" S, 47 53' 23" W), coletados por D. Navia e L. V. F. da Silva, na Coleção Acarológica do Setor de Zoologia, Departamento de Entomologia, Fitopatologia e Zoologia Agrícola da ESALQUSP, Piracicaba, SP, Brasil. 
RELAÇÃO COM HOSPEDEIRO - este ácaro vagrante foi coletado de brotos terminais de A. dubia e Syagrus romanzoffiana (Cham.) Glass., sem causar danos aparentes.

ETIMOLOGIA - A designação específica translinea é derivada do latim trans (transversais) e do latim linea (linha), referindo-se às linhas transversais sobre o epigínio.

OBSERVAÇÃO - Alguns espécimes de Aceria foram coletados de $S$. romanzoffiana (Arecaceae), 11 de Novembro 2000, Estação Ecológica de Ibicatu,

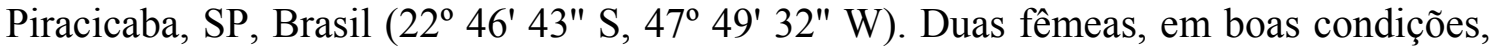

foram idênticas aos espécimes de A. translinea, descritos de A. dubia, diferindo por apresentarem a seta da tíbia (l') (7-9), seta dorsal do tarso ( $\left.f t^{\prime}\right)$ (9-11), seta caudal $\left(h_{2}\right)$ (35-37) e opistossoma (84-89 dorsal anéis e 70-74 ventral anéis) mais longos e seta opistossomal ventral $2(d)(7)$ mais curta.

O epigínio dos espécimes coletados em A. dubia sempre apresentaram linhas transversas microtuberculadas na região proximal e a região distal variável de lisa a quase completamente coberta por linhas transversais lisas. As duas fêmeas coletadas de S. romanzoffiana apresentavam o epigínio completamente ornamentado com linhas transversais lisas e irregulares.

\section{Adenoptus migeoni Navia \& Flechtmann, 2003}

(Figura 4)

DIAGNOSE - Seta antapical bifurcada; primeiros 5-6 anéis opistossomais dorsais medianamente arqueados e completamente microtuberculados; empódio com 3 raios. 


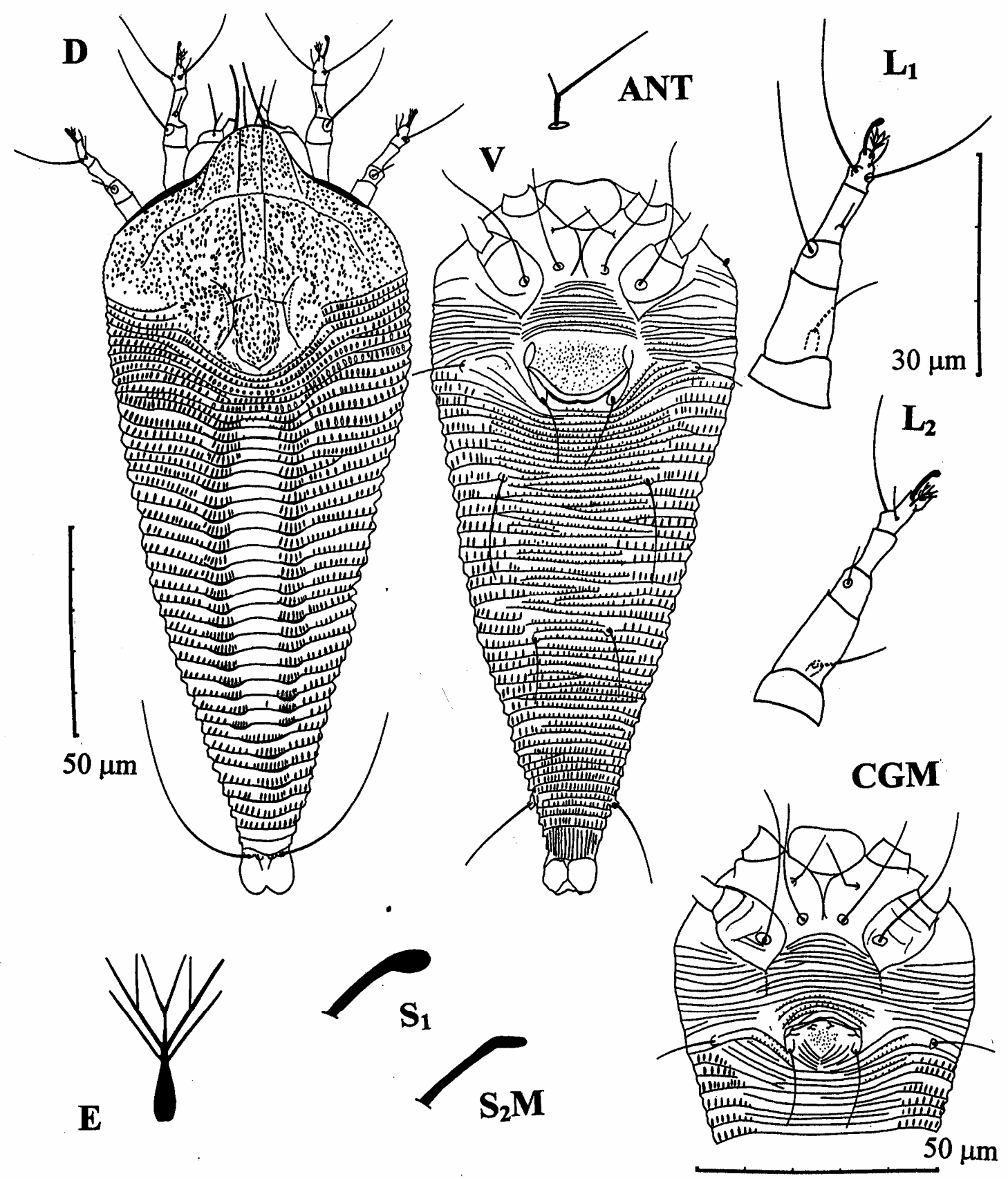

Figura 4 - Adenoptus migeoni sp. n. - D- vista dorsal da fêmea; V- vista ventral da fêmea; ANT- seta antapical; CGM- região coxigenital do macho; GFepigínio de fêmeas de espécimes coletados de Syagrus romanzoffiana; L1- Pernas I; L2- Pernas II; E-empódio; $\mathbf{S}_{\mathbf{1}^{-}}$solenídio da Pernas I; $\mathbf{S}_{2} \mathbf{M}$ - solenídio da Pernas II do macho. (ANT, E, $\mathbf{S}_{1}, \mathbf{S}_{2} \mathbf{M}$ aumentados) 
OBSERVAÇÃO - Adenoptus migeoni Navia \& Flechtmann, 2003a (Phyllocoptinae, Phyllocoptini) apresenta os primeiros 5-6 anéis opistossomais dorsais completamente arqueados medianamente (em Adenoptus chamaeropsi Mitrofanov, Sekerskaya \& Sharonov, 1983 a depressão longitudinal mediana tem início na margem posterior do escudo; epigínio poroso (liso em A. chamaeropsi); seta antapical bifurcada (aparentemente não dividida em $A$. chamaeropsi); empódio com 3 raios (2 pares de raios em A. chamaeropsi).

FÊMEA (n=10) - Corpo fusiforme, com 186 (162-188) de comprimento e 71 (70-83) de largura; coloração em vida amarelo-alarranjado. Gnatossoma projetado para baixo, com 30 (26-31) de comprimento; seta basal (ep) com 4 (3-4) de comprimento; seta antapical (d) bifurcada, com 12 (12-15) de comprimento, ramo curto com (2-3) de comprimento; quelíceras com 25 (22-28) de comprimento; estiletes orais com 20 (14-20) de comprimento. Escudo dorsal com 61 (54-61) de comprimento e 69 (68-82) de largura, subhexagonal, alongado posteriormente, ornamentado com grânulos. Seta escapular (sc) com 5 (4-5) de comprimento, delicada, com 14 (13-18), sobre tubérculos que apresentam a base longitudinal larga, localizados nos $2 / 3$ posteriores do escudo, direcionados centralmente e levemente para frente; setas não se transpassam medianamente. Escudo com uma depressão central posterior entre os tubérculos das setas SC e apresentando uma área delimitada em forma de língua com grânulos mais alongados; linhas medianas na metade anterior do escudo e uma linha transversal curvada paralela à margem antero-lateral do escudo. Lobo frontal largo, subtriangular, apicalmente arredondado, estendendo-se sobre o rostro, com 17 (13-17) de comprimento e 36 (32-40) de largura. Pernas com todas as setas usuais presentes. Pernas I com 36 (33-36) de comprimento; fêmur com 12 (11-13) de comprimento, seta do fêmur (bv) com 12 (10-12) de comprimento; genu com 6 (4-6) de comprimento, seta do genu (l”) com 23 (21-25) de comprimento; tíbia com 10 (8-10) de comprimento, seta da tíbia (l’) com 4(3-4) de comprimento; tarso com 7 (6-7) de comprimento, seta lateral ( $f t$ ”) com 20 (19-21) de comprimento, seta dorsal ( $\left.f t^{\prime}\right)$ com 17 (15-20) de comprimento, seta unguinal ( $\left.u^{\prime}\right)$ com 4 de comprimento, solenídio expandido apicalmente e levemente curvado, em 
forma de uma colher, com 5 (5-6) de comprimento; empódio com 3 de comprimento e com 3 raios. Pernas II com 33 (32-35) de comprimento; fêmur com 12 (11-13) de comprimento, bv com 10 (9-11) de comprimento; genu com 6 (5-6) de comprimento, l", com 5 de comprimento; tíbia com 7 (6-7) de comprimento; tarso com 7 (7-8) de comprimento, ft'’ com 19 (19-20) de comprimento, ft' com 4 de comprimento, u' 4 (34) de comprimento, solenidion como nas pernas I, com 5 (5-6) de comprimento; empódio com 5 de comprimento e com 3 raios. Coxas lisas; linha esternal com 11 (1112) de comprimento. Setas coxais (1b) com 11 (9-12) de comprimento, distanciadas por 15 (12-15); setas coxais 2 (1a) com 26 (25-29) de comprimento, distanciadas por 11 (811); setas coxais 3 (2a) com 39 (38-47) de comprimento, distanciadas por 28 (24-28). Onze (9-11) semi-anéis coxigenitais, com microtubérculos pequenos e esparsos. Epigínio com 26 (23-26) de largura e17 (13-17) de comprimento, com uma leve porosidade, sem linhas longitudinais; seta genital (3a) com 16 (14-16) de comprimento. Opistossoma com 38 (34-38) anéis dorsais, com uma depressão central lisa, ladeada com elevações, apresentando, em seu ápice, proeminentes poros de produção de cera, exceto nos 5 (5-6) anéis dorsais anteriores, os quais são completamente microtuberculados e onde os poros das elevações não estão presentes. Nos 9 (8-9) anéis caudais as elevações se unem. Microtubérculos alongados. Com 54 (46-54) anéis ventrais, com microtubérculos pequenos, localizados um pouco mais à frente da margem posterior dos anéis. Microtubérculos alongados nos últimos anéis. Anéis dorsais estendem-se latero-ventralmente e podem ser vistos em vista ventral, alcançando uma linha imaginária externa lateral às bases das setas ventrais. Seta lateral $\left(c_{2}\right)$ com $13(10-$ 14) de comprimento, sobre o anel 2 (1-3). Setas ventrais (d) com 25 (20-28) de comprimento, separadas por 35 (29-35) e por 30 (25-37) microtubérculos, sobre o anel 11-12 (9-13); setas ventrais 2 (e) com 16 (13-17) de comprimento, separadas por 18 (1518) e por 13 (10-14) microtubérculos, sobre o anel 30-31 (25-31); setas ventrais $3(f)$ laterais, com 21 (19-24) de comprimento, separadas por 21 (19-24) e por 19 (17-23) microtubérculos, sobre o anel 50 (42-50). Seta caudal $\left(h_{2}\right)$ com 48 (43-52) de comprimento; seta acessória $\left(h_{1}\right)$ com 4 (4-5) de comprimento. 
MACHO (n=5) - Menor que a fêmea, com 148-163 de comprimento e 64-68 de largura. Gnatossoma com 23-27 de comprimento; basal seta com 3 de comprimento; seta antapical com 13-15, como na fêmea; quelíceras com 20-22 de comprimento; estiletes orais com 17-20 de comprimento. Escudo dorsal com 50-55 de comprimento e 59-66 de largura. Seta escapular (sc) com 4-5 de comprimento, sobre tubérculos separados entre si por 12-13. Lobo frontal com 11-14 de comprimento e 31-36 de largura. Pernas I com 36-40 de comprimento; fêmur com 12 de comprimento, seta do fêmur (bv) com 10-12 de comprimento; genu com 6 de comprimento, seta do genu (l') com 24-26 de comprimento; tíbia com 10-12 de comprimento, seta da tíbia ( $l$ ') com 4 de comprimento; tarso com 7-8 de comprimento, seta lateral (ft') com 20-21 de comprimento, seta dorsal ( $\left.f t^{\prime}\right)$ com 16-20 de comprimento, seta unguinal ( $\left.u^{\prime}\right)$ com 4-5 de comprimento, solenídio com 5-6 de comprimento; empódio com 5 de comprimento e com 3 raios. Pernas II com 37-39 de comprimento; fêmur com 13-14 de comprimento, bv com 8-11 de comprimento; genu com 6 de comprimento, l" com 6-8 de comprimento; tíbia com 8-10 de comprimento; tarso com 7-8 de comprimento, ft"' com 16-20 de comprimento, $f t^{\prime}$ com 4-6 de comprimento, $u^{\prime}$ com 4-5 de comprimento, solenídio com 7-8 de comprimento, não expandido apicalmente, levemente curvado em vista lateral como um taco de golfe; empódio com 4-5 de comprimento e com 3 raios. Coxas basicamente lisas; algumas poucas linhas longitudinais delicadas nas coxas II. Linha esternal com 12-13 de comprimento. Setas coxais 1 (1b) com 11-12 de comprimento, separadas por 12-13 ; setas coxais 2 (1a) com 27-30 de comprimento, separadas por 8-9; setas coxais 3 (2a) com 38-44 de comprimento, separadas por 24-26; 13-15 semi-anéis coxigenitais, os 3-4 anéis próximos ao epigínio com microtubérculos pequenos. Genitália com 17-19 de largura e 12 de comprimento, um pouco mais pontuada centralmente, papilas como no desenho; ântero-lateralmente estruturas que se assemelham a papilas estão direcionadas para fora; linhas leves transversais ou diagonais são centralmente interrompidas; seta genital (3a) com 15-17 de comprimento. Opistossoma com 32-36 anéis dorsais; 37-41 anéis ventrais. Seta lateral $\left(c_{2}\right)$ com 11-13 de comprimento, sobre o anel 1. Setas ventrais (d) com 20-25 de comprimento, separadas por 28-29 e por 26-27 microtubérculos, sobre o anel 7-8; setas ventrais 2 (e) 
com 14-16 de comprimento, separadas por 13-16 e por 10-14 microtubérculos, sobre o anel 17-20; setas ventrais 3 (f) laterais, com 19-25 de comprimento, separadas por 18-22 e por 18-23 microtubérculos, sobre o anel 33-38. Seta caudal $\left(h_{2}\right)$ com 40-49 de comprimento; seta acessória $\left(h_{1}\right)$ com 3-4 de comprimento.

MATERIAL TIPO - Holótipo fêmea, 27 parátipos fêmeas e 13 parátipos machos em 7 preparações microscópicas, 27 de junho de 2002, de Chamaerops humilis L. (Arecaceae), École Nationale Superieure Agronomique - Montpellier, LanguedocRoussillon, França, coletados por A. Migeon e D. Navia, na Coleção Acarológica do Setor de Zoologia, Departamento de Entomologia, Fitopatologia e Zoologia Agrícola da ESALQ-USP, Piracicaba, SP, Brasil.

RELAÇÃO COM HOSPEDEIRO - este ácaro vagrante foi coletado na superfície adaxial de folhas maduras de C. humilis, sem causar danos aparentes. Os ácaros foram observados movimentando-se rapidamente sobre as folhas.

ETIMOLOGIA - Temos o prazer de nomear esta espécie em homenagem a Alain Migeon, Acarologista, Centre de Biologie et de Gestion des Populations (CBGP), IRDINRA, Montferrier-sur-Lez, Languedoc-Roussillon, França.

\section{Glabrisceles Navia \& Flechtmann, 2002}

(Figura 5)

DIAGNOSE - As características que distinguem este novo gênero de Phyllocoptinae, Tegonotini são: seta antapical bifurcada; fusão dos anéis opistossomais dorsais anteriores; Anéis opistossomais diferenciados dorsventralmente em dorsais largos e lisos e ventrais estreitos e microtuberculados; ausência das setas opistossomais ventrais 1 e $2(d, e)$; redução das setas das pernas: setas dos fêmures I e II $(b v)$ e setas da tíbia (l') e do genu II (l’) ausentes. 


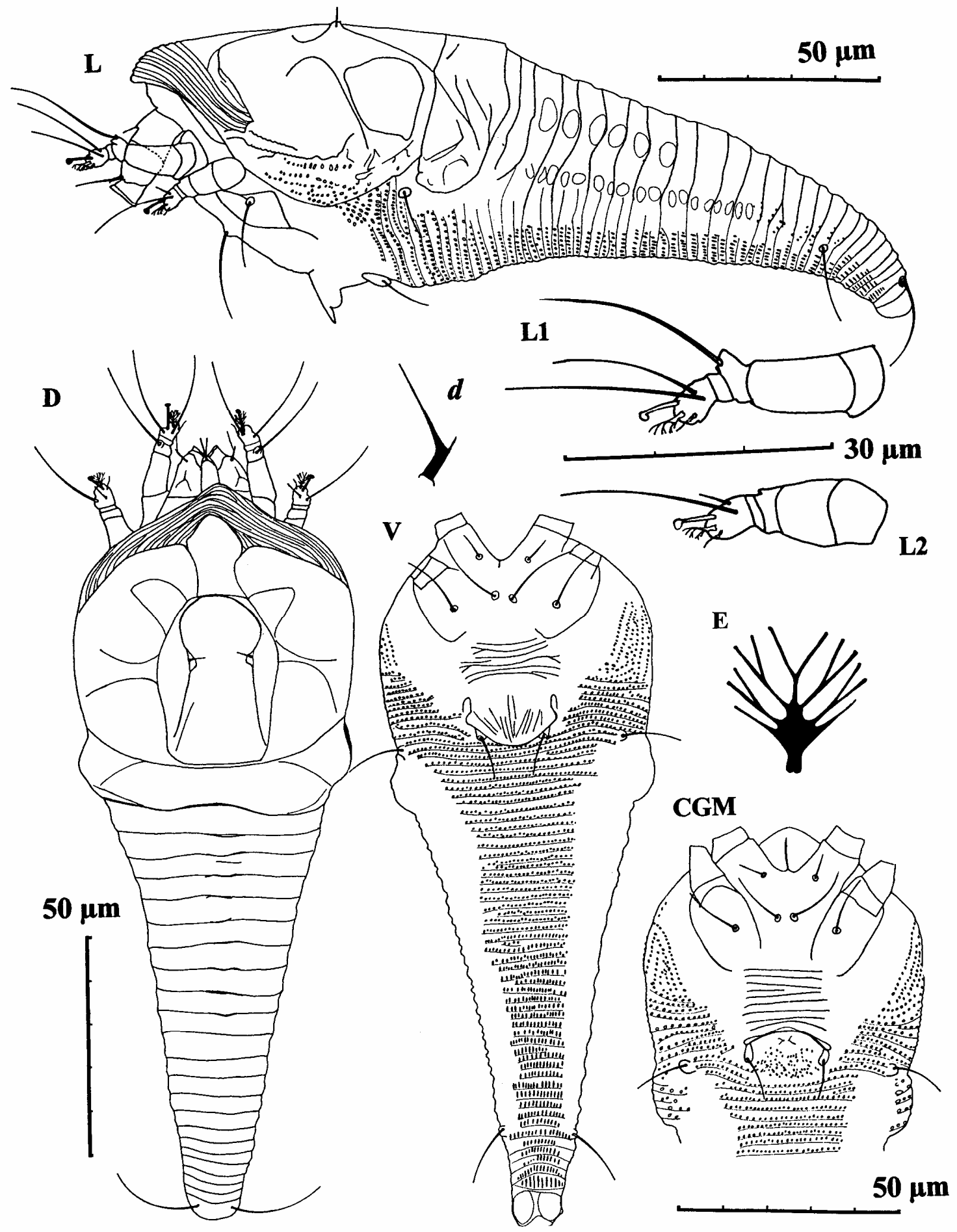

Figura 5 - Glabrisceles euterpis Navia \& Flechtmann, 2002- D- vista dorsal da fêmea; V- vista ventral da fêmea; L- vista lateral da fêmea; CGM- região coxigenital do macho; AN- seta antapical; L1- Pernas I; L2- Pernas II; Eempódio. (AN e $\mathbf{E}$ aumentados) 
Corpo fusiforme, escudo dorsal e parte anterior do opistossoma largos. Escudo com lobo frontal bem desenvolvido sobre o rostro; tubérculos dorsais posicionados bastante à frente da margem posterior do escudo. Coxas com todas as setas presentes; coxas I fundidas.

OBSERVAÇÃO - Este gênero se assemelha a Dicrothrix Keifer, 1966 em seu aspecto geral; difere deste na quetotaxia reduzida das pernas (todas as setas usuais das pernas presentes em Dicrothrix), na diferenciação dorso-ventral do opistossoma (anéis dorsais em mesmo número e largura em Dicrothrix).

ESPÉCIE TIPO - Glabrisceles euterpis Navia \& Flechtmann, 2002

ETIMOLOGIA - o nome genérico Glabrisceles é derivado do grego skelos, sceles (pernas) e do latim glaber (glabro), referindo-se a quetotaxia reduzida das pernas. Gênero: neutro.

\section{Glabrisceles euterpis sp. $\mathbf{n}$.}

(Figura 5)

FÊMEA - (n=10). Comprimento do corpo 151 (142-155), largura 56 (51-58), fusiforme, esbranquiçada. Gnatossoma curvado ventralmente em um ângulo obtuso, com 15 (15-19) de comprimento. Seta antapical (d) em forma de cotovelo, bifurcada, com a porção proximal alargada, o ramo curto apresenta cerca de 1/6 do comprimento do ramo mais longo, com 7 (7-9) de comprimento; seta basal (ep) com 3 (2-3) de comprimento; quelíceras com 14 (13-16) de comprimento; estiletes orais com 10 (10-11) de comprimento. Escudo dorsal com 55 (53-60) de comprimento e 54 (47-55) de largura, subpentagonal, com ângulos anteriores arredondados; lobo frontal com 8 (8-11) de comprimento, arredondado, com a base larga, espesso, com ranhuras na região anterior que continuam na margem antero-dorsal do escudo; estas ranhuras dão a impressão de formarem camadas. Setas escapulares do escudo dorsal (sc) com 4 (3-4) de comprimento, direcionadas para cima e centralmente, sobre tubérculos bem 
desenvolvidos que estão em uma elevação do escudo, separados entre si por 11 (11-13). Tegumento do escudo levemente estriado; padrão dorsal do escudo complexo, como mostrado na Figura 5. Anéis opistossomais ântero-dorsais formando uma larga placa fundida ao escudo dorsal, com a margem posterior sinuosa, com 9 (8-11) de comprimento. Pernas - ausência da seta da tíbia ( $l$ ') das pernas I, da seta do genu (l”) das pernas II e setas femurais $(b v)$. Pernas I com 18 (18-19) de comprimento; fêmur com 9 (8-9) de comprimento; genu com 3 (3-4) de comprimento; seta do genu (l”) com 18 (18-20) de comprimento, sobre um tubérculo proeminente; tíbia reduced com 2 de comprimento; tarso com 4 de comprimento; seta lateral (ft”) com 18 (16-18) de comprimento, seta dorsal ( $\left.f t^{\prime}\right)$ com 14 (12-15) de comprimento; seta unguinal ( $u$ ') com 3 (2-3) de comprimento; solenídio com 4 de comprimento, extremidade expandida arredondada; empódio com 4 de comprimento e com 4 raios. Pernas II com 16 (15-17) de comprimento; fêmur com 7 (6-7) de comprimento; genu com 2 (2-3) de comprimento; tíbia com 2 de comprimento; tarso com 4 de comprimento; seta lateral ( ft”) com 15 (15-18) de comprimento, seta dorsal ( $\left.f t^{\prime}\right)$ com 3 (3-4) de comprimento, seta unguinal ( $u$ ') com 2 (2-3) de comprimento, solenídio com 4 de comprimento, como nas pernas I; empódio com 4 de comprimento e com 4 raios. Setas coxais 1 (1b) separadas por 10 (10-11), com 5 (4-6) de comprimento; setas coxais 2 (1a) separadas por 4 (3-4), com 12 (12-18) de comprimento; setas coxais 3 (2a) separadas por 20 (18-20), com 14 (14-17) de comprimento. Coxas lisas. Linha esternal curta, com 4 de comprimento, ausente em alguns espécimes. Região coxiesternal com 7 (6-7) semi-anéis, lisos. Últimos anéis coxiesternais distintamente separados da margem anterior do epigínio. Epigínio sem margem anterior, com 18 de largura e 11 (11-12) de comprimento, com 13 (13-17) linhas longitudinais e radiais; seta genital (3a) com 10 (8-10) de comprimento.

Opistossoma bem diferenciado dorso-ventralmente, com uma elevação dorso-mediana, estendendo-se sobre a metade anterior do opistossoma. Anéis dorsais lisos, largos; anéis ventrais estreitos, microtuberculados; microtubérculos pequenos e arredondados próximos à margem posterior dos anéis, os quais tornam-se alongados na metdade posterior do opistossoma. Seta lateral $\left(c_{2}\right)$ com 11 (11-12) de comprimento, sobre o anel 2 (2-5); setas ventrais $1(d)$ e $2(e)$ ausentes; setas ventrais $3(f)$ sobre o anel 48 (47-51), 
separadas por 16 (16-19) e por 24 (19-24) microtubérculos, com 13 (11-14) de comprimento. Total de anéis dorsais 23 (22-24), total de anéis ventrais 53 (51-56). Seta caudal $\left(h_{2}\right)$ com 25 (22-25) de comprimento; seta acessória $\left(h_{1}\right)$ ausente.

MACHO - (n=5) Menor que a fêmea, com 122-143 de comprimento e 45-53 de largura. Gnatossoma com 14 de comprimento. Seta antapical $(d)$ como na fêmea, com 6-9 de comprimento; ep com 2-3 de comprimento; curvado ventralmente em um ângulo obtuso. Escudo dorsal como na fêmea, com 46-55 de comprimento e 40-51 de largura; SC com 3 de comprimento, tubérculos separados por 10-11; lobe frontal com 7-9 de comprimento. Placa larga na região antero-dorsal do opistossoma, como na fêmea, com 9 de comprimento. Pernas como na fêmea. Pernas I com 17-18 de comprimento; fêmur com 7-9 de comprimento; genu com 2-3 de comprimento, l” com 18-19 de comprimento; tíbia com 1-2 de comprimento; tarso com 4 de comprimento, ft" com 1618 de comprimento, $f t$ ' com 11-14 de comprimento, $u$ ' com 2 de comprimento, solenídio com 3-4 de comprimento, como na fêmea; empódio com 3-4 de comprimento e com 4 raios. Pernas II com 14-16 de comprimento; fêmur 6-7 de comprimento; genu com 2 de comprimento; tíbia com 1-2 de comprimento; tarso com 3-4 de comprimento, ft” com 14-15 de comprimento, $f t^{\prime}$ com 2-4 de comprimento, $u$ ' com 1-2 de comprimento, solenídio com 4 de comprimento, empódio com 3-4 de comprimento e com 4 raios. Coxas como na fêmea: $1 b$ separadas por 9-10, com 4-5 de comprimento; $1 a$ separadas por 3-4, com 13-18 de comprimento; $2 a$ separadas por 18-20, com 11-12 de comprimento. Região coxiesternal como na fêmea, com 7-9 semi-anéis. Genitália com 15-16 de largura, 8-9 de comprimento, com grânulos na região posterior às papilas, como no desenho; $3 a$ com 7-9 de comprimento. Opistossoma como na fêmea, $c_{2}$ com 9-11 de comprimento, sobre o anel 1; $f$ sobre o anel 39-46, separadas por 13-15 e por 13-19 microtubérculos, com 10-13 de comprimento. Total de anéis dorsais 21-23, total de anéis ventrais 45-51. Região caudal: $h_{2} \operatorname{com} 24-28$ de comprimento.

MATERIAL TIPO - Holótipo fêmea, 16 parátipos fêmeas, 11 parátipos machos em 5 preparações microscópicas, 19 de abril de 2000; 16 parátipos fêmeas, 3 parátipos 
machos em 4 preparações microscópicas, 14 de junho de 2000, de Euterpe edulis Mart. (Arecaceae), "Estação Experimental do Instituto Agronômico de Campinas", PariqueraAçu, São Paulo, Brasil ( $24^{\circ} 36^{\prime} 41^{\prime \prime}$ S, $47^{\circ} 53^{\prime}$ 23" W), coletados por D. Navia e L. V. F. da Silva, na Coleção Acarológica do Setor de Zoologia, Departamento de Entomologia, Fitopatologia e Zoologia Agrícola da ESALQ-USP, Piracicaba, SP, Brasil.

RELAÇÃO COM HOSPEDEIRO - este ácaro vagrante foi coletado em brotos terminais de E. edulis, sem causar danos aparentes.

ETIMOLOGIA - A designação específica is derivada do nome genérico da planta hospedeira, E. edulis.

\section{Nasuchus Navia \& Flechtmann, 2002}

(Figura 6)

DIAGNOSE - Este novo gênero a ser descrito apresenta a seta escapular (sc) em forma de espinho, bem à frente da margem posterior do escudo; seta do fêmur ( $b v$ ) ausente; dorso do opistossoma com três elevações longitudinais; os primeiros anéis dorsais do opistossoma fundidos em uma placa; setas opistossomais lateral e ventral 2 $\left(c_{2}, e\right)$ ausentes.

OBSERVAÇÃO - Este gênero de Phyllocoptinae, Acaricalini é próximo a Tumescoptes Keifer, 1939a, entretanto, a placa da região ântero-dorsal do opistossoma é contígua ao escudo dorsal (separada por pelo menos três anéis estreitos em Tumescoptes); o idiossoma estreita-se gradualmente na região posterior (opistossoma abruptamente afilado em Tumescoptes); os anéis dorsais apresentam três elevações longitudinais (uniformemente arqueado ou com apenas duas elevações laterais em Tumescoptes). 


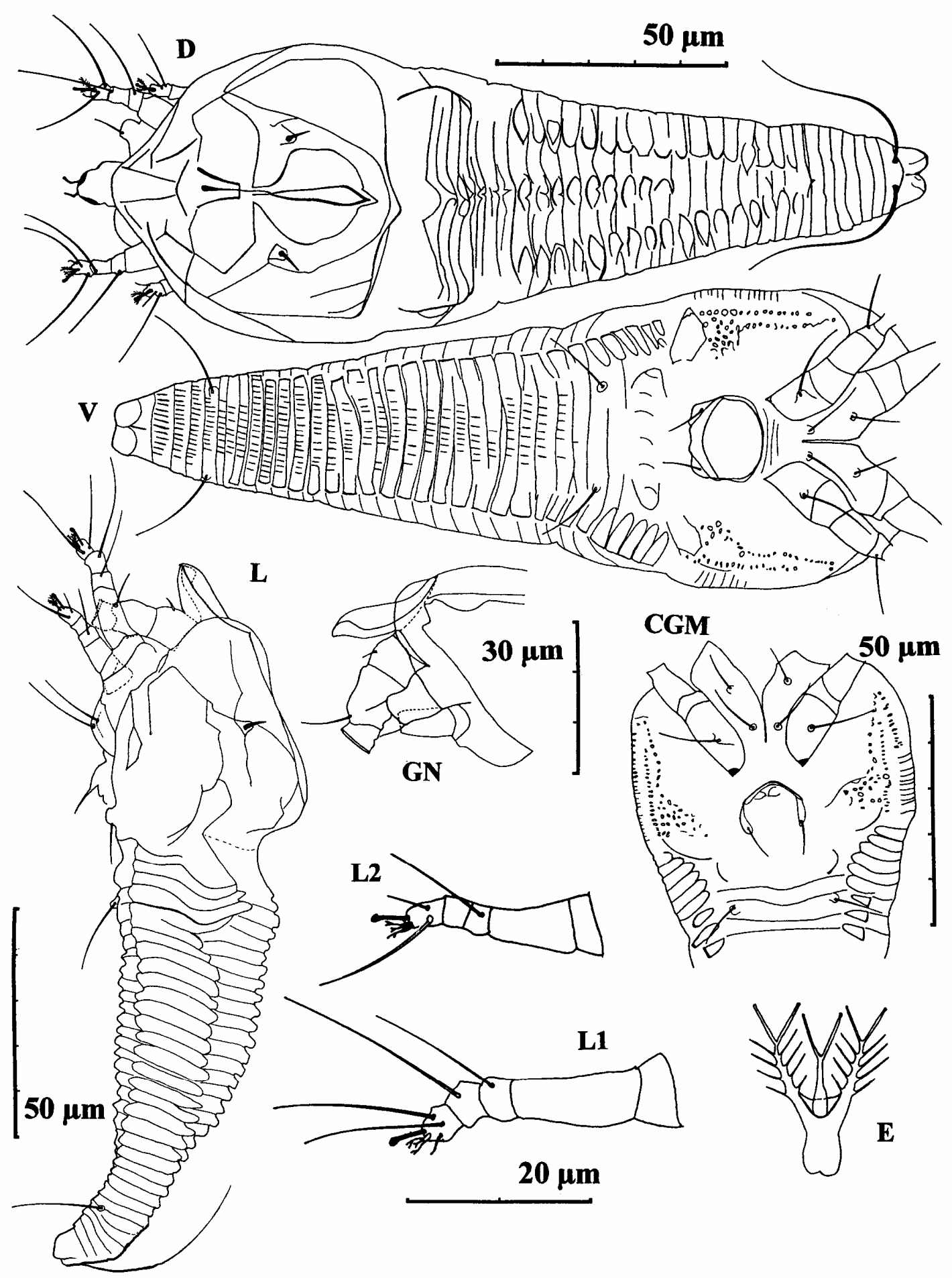

Figura 6 - Nasuchus pindobates Navia \& Flechtmann, 2002- D- vista dorsal da fêmea; V- vista ventral da fêmea; L- vista lateral da fêmea; GN- região do gnatossoma; CGM- região coxigenital do macho; L1- Pernas I; L2- Pernas II; E- empódio (aumentado) 
ESPÉCIE TIPO: Nasuchus pindobates Navia \& Flechtmann, 2002

ETIMOLOGIA - Nasuchus é derivado do latim masculino nasus (nariz) e do sufixo latino -uchus (que pertence, apresenta), referindo-se à proeminente projeção no lobo frontal. Gênero masculino.

\section{Nasuchus pindobates Navia \& Flechtmann, 2002}

(Figura 6)

FÊMEA - (n=6) Comprimento do corpo 158 (153-174), largura 58 (57-61), fusiforme, esbranquiçadas. Gnatossoma curvado ventralmente em um ângulo obtuso, com 18 (18-22) de comprimento. Seta antapical $(d)$ com 8 (7-8) de comprimento; seta basal (ep) com 2 (2-3) de comprimento; quelíceras com 15 (14-18) de comprimento; estiletes orais com 11 de comprimento. Escudo dorsal com 54 (51-60) de comprimento e 57 (55-60) de largura, subpentagonal, com ângulos póstero-laterais arredondados; lobo frontal arredondado e com a base larga, com uma proeminente projeção em forma de capuz resultante da fusão de duas peças (Figura 6- GN), aparentemente partindo da base do palpo, com 15 (15-17) de comprimento. Setas escapulares do escudo dorsal (sc) modifificadas em forma de espinhos, com 4 de comprimento, direcionadas para cima, sobre tubérculos bem desenvolvidos, separados entre si por 19 (18-19), localizados em elevações do escudo. Escudo com elevação da região externa para a região central; depressão longitudinal na área central; pequena extensão na margem posterior. Pernas: seta femural ( $b v)$ ausente em ambas as pernas. Pernas I com 25 (24-26) de comprimento; fêmur com 11 (11-13) de comprimento; genu com 3 (3-4) de comprimento; seta do genu (l”) com 15 (15-18) de comprimento; tíbia com 4 de comprimento; seta da tíbia (l') com 18 (18-20) de comprimento; tarso com 4 (4-5) de comprimento; seta lateral ( $\left.f t^{\prime \prime}\right)$ com 18 (15-18) de comprimento; seta dorsal ( $\left.f t^{\prime}\right)$ com 14 (11-15) de comprimento; seta unguinal ( $\left.u^{\prime}\right)$ com 3 de comprimento; solenídio com 4 de comprimento, empódio com 4 de comprimento, tripartido, dividido em dois ramos com 5 raios laterais e um central, o 
qual é menor e sem raios, mas apicalmente bifurcado. Pernas II com 20 (20-21) de comprimento; fêmur com 9 (9-10) de comprimento; genu com 3 de comprimento; seta do genu (l”) com 11 (10-11) de comprimento; tíbia com 4 de comprimento; tarso com 4 de comprimento; seta lateral (ft”) com 13 (13-18) de comprimento; seta dorsal (ft') com 4 de comprimento, seta unguinal ( $\left.u^{\prime}\right)$ com 3 (2-3) de comprimento, solenídio com 4 de comprimento; empódio com 4 de comprimento, como nas pernas I, ramos laterais com 5 (4-5) raios. Setas coxais 1 (1b) separadas por 11 (10-11), com 10 (9-10) de comprimento; setas coxais 2 (1a) separadas por 4, com 12 (12-16) de comprimento; setas coxais 3 (2a) separadas por 19 (18-19), com 15 (15-18) de comprimento. Coxas sem grânulos, lisas. Linha esternal com 11 de comprimento. Região coxiesternal com 3 (1-3) semi-anéis, lisos. Epigínio com 17 (16-17) de largura e 14 (14-16) de comprimento, lisos; seta genital (3a) com 8 (6-9) de comprimento. Opistossoma com três elevações dorso longitudinais: uma central estendendo-se sobre a metade anterior do opistossoma e duas laterais estendendo-se sobre os 3/4 anteriores do opistossoma; os primeiros cinco anéis opistossomais dorsais fundidos em uma placa, em que são distintos cerca de quatro anéis. Ventralmente, duas elevações laterais estendendo-se sobre 3/4 do opistossoma; os primeiros quatro anéis ventrais não são distintos na região central, mas fundidos em uma placa. Anéis dorsais sem microtubérculos; anéis ventrais com microtubérculos alongados, esparsos sobre os 2/3 anteriores do opistossoma e densamente microtuberculados no $1 / 3$ posterior do opistossoma. Seta lateral $\left(c_{2}\right)$ e setas ventrais 2 (e) ausentes; setas ventrais $1(d)$ sobre o anel 3 (2-4), distanciadas por 22 (1922), com 17 (15-19) de comprimento; setas ventrais 3 ( $f$ ) sobre o anel 26-27 (25-28), 18 (16-18) de comprimento, distanciadas por 17 e por 20 (17-20) microtubérculos. Total de anéis dorsais 33(31-33), total de anéis ventrais 30 (29-31). Seta caudal $\left(h_{2}\right)$ com 32 (3133) de comprimento; seta acessória $\left(h_{1}\right)$ ausente.

MACHO - $(n=1)$. Menor que a fêmea, 143 de comprimento, 55 de largura. Gnatossoma com 19 de comprimento. Seta antapical (d) com 6 de comprimento; ep com 2 de comprimento; quelíceras com 14 de comprimento; estiletes orais com 11 de comprimento; curvados ventralmente em um ângulo obtuso. Escudo dorsal como na 
fêmea, com 48 de comprimento e 55 de largura; SC com 4 de comprimento; tubérculos dorsais separados por 19. Pernas como na fêmea. Pernas I com 25 de comprimento; fêmur com 11 de comprimento; genu com 4 de comprimento; l” com 14 de comprimento; tíbia com 4 de comprimento; l' com 18 de comprimento; tarso com 4 (45) de comprimento; $f t$ ” com 18 de comprimento; $f t$ ' com 11 de comprimento; $u$ ' com 2 de comprimento; solenídio com 4 de comprimento, empódio como na fêmea, com 4 de comprimento, ramos laterais com 5 raios. Pernas II com 20 de comprimento; fêmur com 9 de comprimento, genu com 3 de comprimento, l” com 9 de comprimento; tíbia com 3 de comprimento; tarso com 4 de comprimento, solenídio com 4 de comprimento, empódio com 4 de comprimento, ramos laterais com 5 (4-5) raios. Coxas: $1 b$ separadas por 13, com 9 de comprimento; $1 a$ separadas por 4, com 11 de comprimento; $2 a$ separadas por 18, com 18 de comprimento. Linha esternal com 11 de comprimento. Coxas como na fêmea. Região coxiesternal sem anéis, lisa. Genitália com 12 de largura e 9 de comprimento, lisa; $3 a$ com 6 de comprimento. Opistossoma como na fêmea; $d$ sobre o anel 3, separadas por 19, com 11 de comprimento; $f$ sobre o anel 26-27, separadas por 17 e por 15 microtubérculos, com 18 de comprimento. Total de anéis dorsais 32 , total de anéis ventrais 30 . Região caudal como na fêmea, $h_{2}$ com 33 de comprimento.

MATERIAL TIPO - Holótipo fêmea, 5 parátipos fêmeas, 1 parátipo macho, em duas preparações microscópicas, 4 de dezembro de 2000, de Geonoma gamiovora Barb. Rodr. (Arecaceae), "Estação Ecológica de Jataí", Luiz Antônio, São Paulo, Brasil (21 ${ }^{\circ}$ 36' 13" S, 47 47' 17" W), coletados por D. Navia e L. V. F. da Silva, na Coleção Acarológica do Setor de Zoologia, Departamento de Entomologia, Fitopatologia e Zoologia Agrícola da ESALQ-USP, Piracicaba, SP, Brasil.

RELAÇÃO COM HOSPEDEIRO - este ácaro vagrante foi coletado na superfície inferior de folhas de G. gamiovora sp., sem causar danos aparentes. 
ETIMOLOGIA - A designação específica pindobates é derivada do tupi (linguagem indígena brasileira) pindoua (palmeira) e do grego bates (que caminha).

\section{Notostrix acuminata Navia \& Flechtmann, 2003}

(Figura 7)

DIAGNOSE - Notostrix acuminata Navia \& Flechtmann, 2003b é distinta de todas as demais espécies do gênero até então descritas por apresentar o escudo ornamentado com grânulos delicados, alongados e irregularmente cobertos por cera (regiões laterais com faixas). Estes grânulos ocupam a área delimitada pelas linhas submarginais; a área exterior às linhas submarginais é lisa (proeminentes grânulos arredondados em todo o escudo dorsal em Notostrix flabellifera Mohanasundaram, 1982; escudo liso nas demais espécies). Lobo frontal apicalmente afilado (apicalmente arredondado nas outras espécies).

FÊMEA ( $\mathrm{n}=10)$ - Corpo fino, alongado, com 226 (178-226) de comprimento e 55 (44-55) de largura; coloração branca-amarelada. Escudo dorsal: com os 3-4 primeiros anéis opistossomais e as margens laterais do opistossoma cobertos com cera. Gnatossoma projetado para baixo, com 23 (22-24) de comprimento; seta basal (ep) com 3 (3-4) de comprimento; seta antapical $(d)$ com 6 (5-7) de comprimento; quelíceras com 15 (14-16) de comprimento; estiletes orais com 12 de comprimento. Escudo dorsal subtriangular, com 53 (41-53) de comprimento e 44 (41-44) de largura. Setas escapulares (sc) com 10 (9-10) de comprimento (estendendo-se além da margem posterior do escudo), sobre tubérculos distanciados entre si por 16 (15-18), direcionados para cima e para trás, levemente divergentes, inseridos nos $4 / 5$ posterior do escudo. Desenho do escudo consiste em uma linha submarginal, paralela à margem do mesmo; duas linhas medianas divergindo na região próxima à margem posterior; área delimitada pelas linhas submarginais ornamentada com grânulos delicados, alongados e irregulares, cobertos por cera; estes grânulos são mais alongados nas regiões laterais. Lobo frontal 


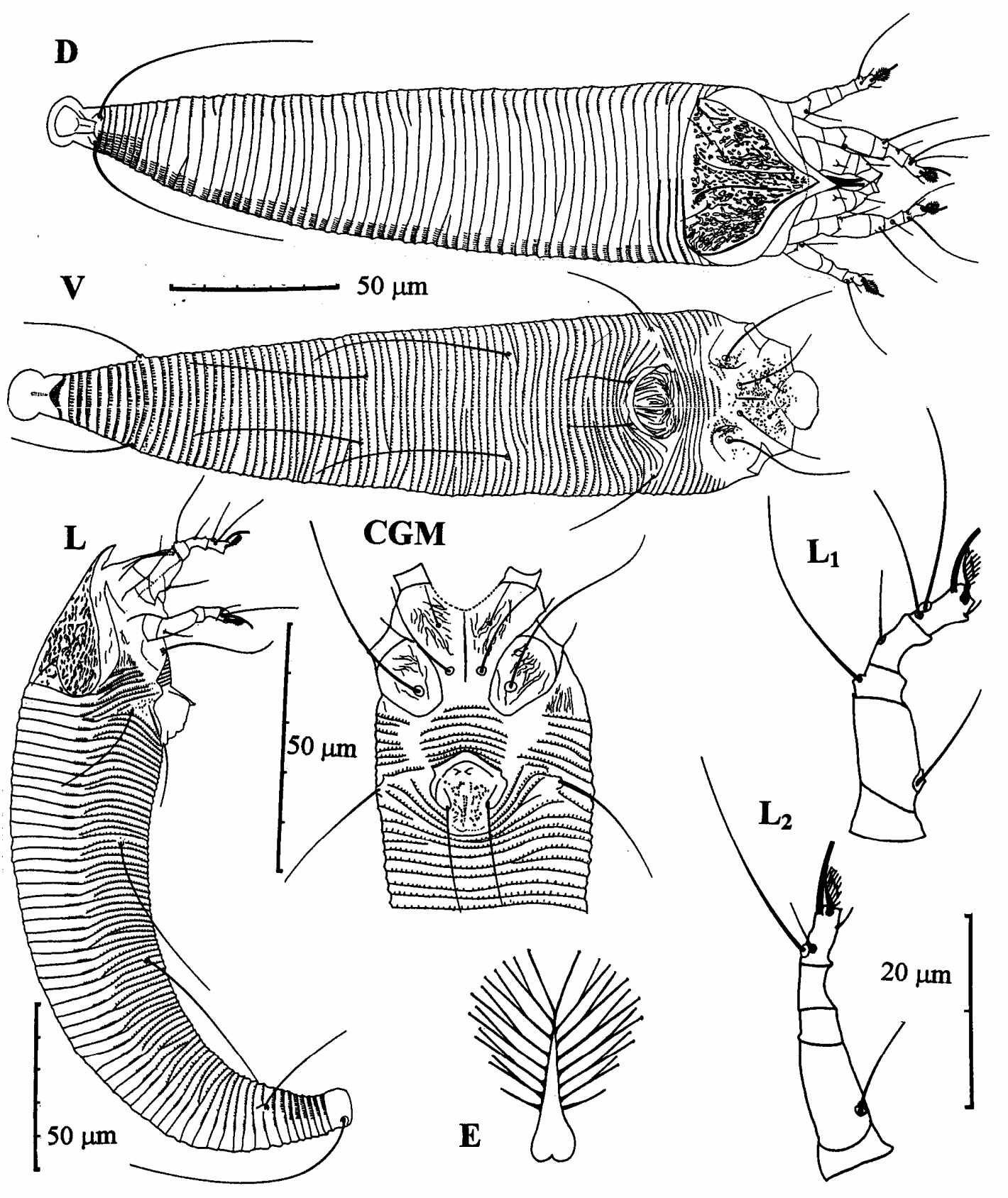

Figura 7 - Notostrix acuminata Navia \& Flechtmann, 2003- D- vista dorsal da fêmea; V-vista ventral da fêmea; L- vista lateral da fêmea; CGM- região coxigenital do macho; L1- Pernas I; L2- Pernas II; E- empódio (aumentado) 
subtriangular, apicalmente pontudo, estendendo-se sobre o rostro, com 9 (7-9) de comprimento, base com 12 (11-14) de largura. Pernas não apresentam seta no genu das pernas II. Pernas I com 31 (29-32) de comprimento; fêmur com 12 (10-12) de comprimento, seta do fêmur $(b v)$ com 14 (10-14) de comprimento; genu com 4 (4-5) de comprimento, seta do genu (l') com 22 (21-23) de comprimento; tíbia com 6 (6-7) de comprimento, seta da tíbia (l') com 7 (7-9) de comprimento; tarso com 7 (6-7) de comprimento, seta lateral ( $\left.f t^{\prime \prime}\right)$ com 22 (20-23) de comprimento, seta dorsal ( $\left.f t^{\prime}\right)$ com 14 (14-17) de comprimento, seta unguinal ( $\left.u^{\prime}\right)$ com 4 (3-4) de comprimento, solenídio com 7 (7-8) de comprimento; empódio com 6 (6-7) de comprimento, não dividido, com 8 raios. Pernas II com 27 (26-30) de comprimento; fêmur com 11 (10-11) de comprimento, bv com 9 (9-11) de comprimento; genu com 4 (4-5) de comprimento, l", ausente; tíbia com 5 (5-6) de comprimento; tarso com 6 (6-7) de comprimento, ft" com 25 (22-26) de comprimento, ft' com 5 (5-8) de comprimento, $u^{\prime}$ com 3 (3-5) de comprimento, solenídio com 7 (7-9) de comprimento; empódio com 7 (6-7) de comprimento, como nas pernas I, com 7 (7-8) raios. Coxas com grânulos, algumas linhas delicadas nas coxas II; coxas contínuas com o hipostômio. Linha esternal fraca, externa, com 9 (7-11) de comprimento. Setas coxais 1 (1b) com 9 (8-10) de comprimento, separadas por 11 (9-11); setas coxais 2 (1a) com 25 (23-29) de comprimento, separadas por 8 (6-8); setas coxais 3 (2a) com 37 (36-38) de comprimento, separadas por 24 (19-25); com 9 (8-9) semi-anéis coxigenitais, microtuberculados. Epigínio com 22 (20-24) de largura e 17 (14-18) de comprimento, com 17 (15-17) linhas longitudinais; algumas das linhas longitudinais são unidas anteriormente por linhas curvas (ou são dobradas); algumas poucas linhas transversais irregulares curtas cruzam o epigínio basalmente; seta genital (3a) com 18 (16-18) de comprimento. Opistossoma com 56 (52-60) anéis dorsais; microtubérculos dorsolaterais pequenos e arredondados produzindo franjas de cera; depressão central larga; anéis dorsais lisos lateralmente; 70 (67-79) anéis ventrais, com microtubérculos pequenos e arredondados, localizados um pouco à frente da borda posterior dos anéis, mais alongados nos anéis telessomais. Seta lateral $\left(c_{2}\right)$ com 28 (25-30) de comprimento, sobre o anel $1(0-1)$. Setas ventrais $1(d)$ com 58 (58-69) de comprimento, separadas por 
29 (24-29) e por 28 (23-34) microtubérculos, sobre o anel 16-17 (15-20); setas ventrais 2 (e) com 49 (44-53) de comprimento, separadas por 20 (16-20) e por 15 (13-19) microtubérculos, sobre o anel 35-36 (31-41); setas ventrais 3 (f) laterais, com 36 (32-38) de comprimento, separadas por 25 (20-25) e por 26 (23-26) microtubérculos, sobre o anel 61-62 (57-65). Seta caudal $\left(h_{2}\right)$ com 62 (58-72) de comprimento; seta acessória $\left(h_{1}\right)$ ausente.

MACHO - (n=5) Menor do que a fêmea, com 170-202 de comprimento e 38-47 de largura. Gnatossoma com 19-22 de comprimento; seta basal (ep) com 3 de comprimento; seta antapical (d) com 8-9 de comprimento; quelíceras com 12-15 de comprimento. Escudo dorsal com 38-41 de comprimento e 36-42 de largura. Setas escapulares $(s c)$ com 8-9 de comprimento, sobre tubérculos distanciados por 12-15. Lobo frontal com 6-8 de comprimento, base com 8-10 de largura. Pernas como na fêmea. Pernas I com 27-30 de comprimento; fêmur com 10-12 de comprimento, $b v$ com 11-15 de comprimento; genu 4-5 de comprimento, l' ' com 18-20 de comprimento; tíbia 6 de comprimento, l' com 6-8 de comprimento; tarso com 5-6 de comprimento, ft'” com 16-19 de comprimento, $f t^{\prime}$ com 12-14 de comprimento, $u$ ' com 3 de comprimento, solenídio com 7-8 de comprimento; empódio com 6 de comprimento, como na fêmea, 67 raios. Pernas II com 26-27 de comprimento; fêmur com 9-11 de comprimento, bv 7-11 de comprimento; genu com 4 de comprimento; tíbia com 5-6 de comprimento; tarso com 5 de comprimento, $f t$ '’ com 20-22 de comprimento, ft' com 5-6 de comprimento, $u$ ' com 2-3 de comprimento, solenídio com 8-9 de comprimento; empódio com 5-6 de comprimento, 6-7 raios. Coxas com linhas curvas fracas. Linha esternal com 8-12 de comprimento. Setas coxais 1 (1b) 8-9 de comprimento, separadas por 8-9; setas coxais 2 (1a) com 18-22 de comprimento, separadas por 5; setas coxais 3 (2a) com 34-40 de comprimento, separadas por 15-18; 7-8 semi-anéis coxigenitais, microtuberculados. Genitália com 13-16 de largura e 12-14 de comprimento, com grânulos; papilas como no desenho; seta genital (3a) com 14-19 de comprimento. Opistossoma com 53-59 anéis dorsais; 60-64 anéis ventrais. Seta lateral $\left(c_{2}\right)$ com 22-24 de comprimento, sobre o anel 1-2. Setas ventrais 1 (d) com 46-48 de comprimento, separadas por 19-21 e por 16-19 
microtubérculos, sobre o anel 11-14; setas ventrais 2 (e) com 36-41 de comprimento, separadas por 12-13 e por 9-13 microtubérculos, sobre o anel 27-31; setas ventrais $3(f)$ laterais, com 28-34 de comprimento, separadas por 19-22 e por 15-23 microtubérculos, sobre o anel 51-56. Seta caudal $\left(h_{2}\right)$ com 49-55 de comprimento; seta acessória $\left(h_{1}\right)$ ausente.

MATERIAL TIPO - Holótipo fêmea, 22 parátipos fêmeas e 8 parátipos machos, em 8 preparações microscópicas, 11 de novembro de 2000, de brotos terminais e da superfície inferior de folhas de A. aculeata, Ibicatu, Piracicaba (22 46'43' S, $47^{\circ}$ 49’32' W), São Paulo, Brasil, coletados por D. Navia e L.V.F. da Silva. Três parátipos fêmeas adicionais em 2 preparações microscópicas, 11 de novembro de 2000 de folhas de Syagrus oleracea Beccari (Arecaceae) de São Pedro, São Paulo, Brasil (22 38' 58', S, $47^{\circ} 48^{\prime} 31^{\prime \prime}$ W) coletados por D. Navia e L.V.F. da Silva, na Coleção Acarológica do Setor de Zoologia, Departamento de Entomologia, Fitopatologia e Zoologia Agrícola da ESALQ-USP, Piracicaba, SP, Brasil.

RELAÇÃO COM HOSPEDEIRO - vagrante sobre brotos terminais e folhas e são facilmente vistos como faixas de cera esbranquiçada.

ETIMOLOGIA - a designação específica acuminata é derivada do latim acumen (uma ponta aguda), referindo-se ao lobo frontal do escudo dorsal subtriangular e com a ponta afilada.

\section{Notostrix fissipes Navia \& Flechtmann, 2003}

(Figura 8)

DIAGNOSE - Notostrix fissipes Navia \& Flechtmann, 2003b (Phyllocoptinae, Phyllocoptini) difere de todas as outras espécies de Notostrix até então descritas por apresentar os empódios bipartidos, cada ramo com 6-7 raios (tripartido em N. exigua 


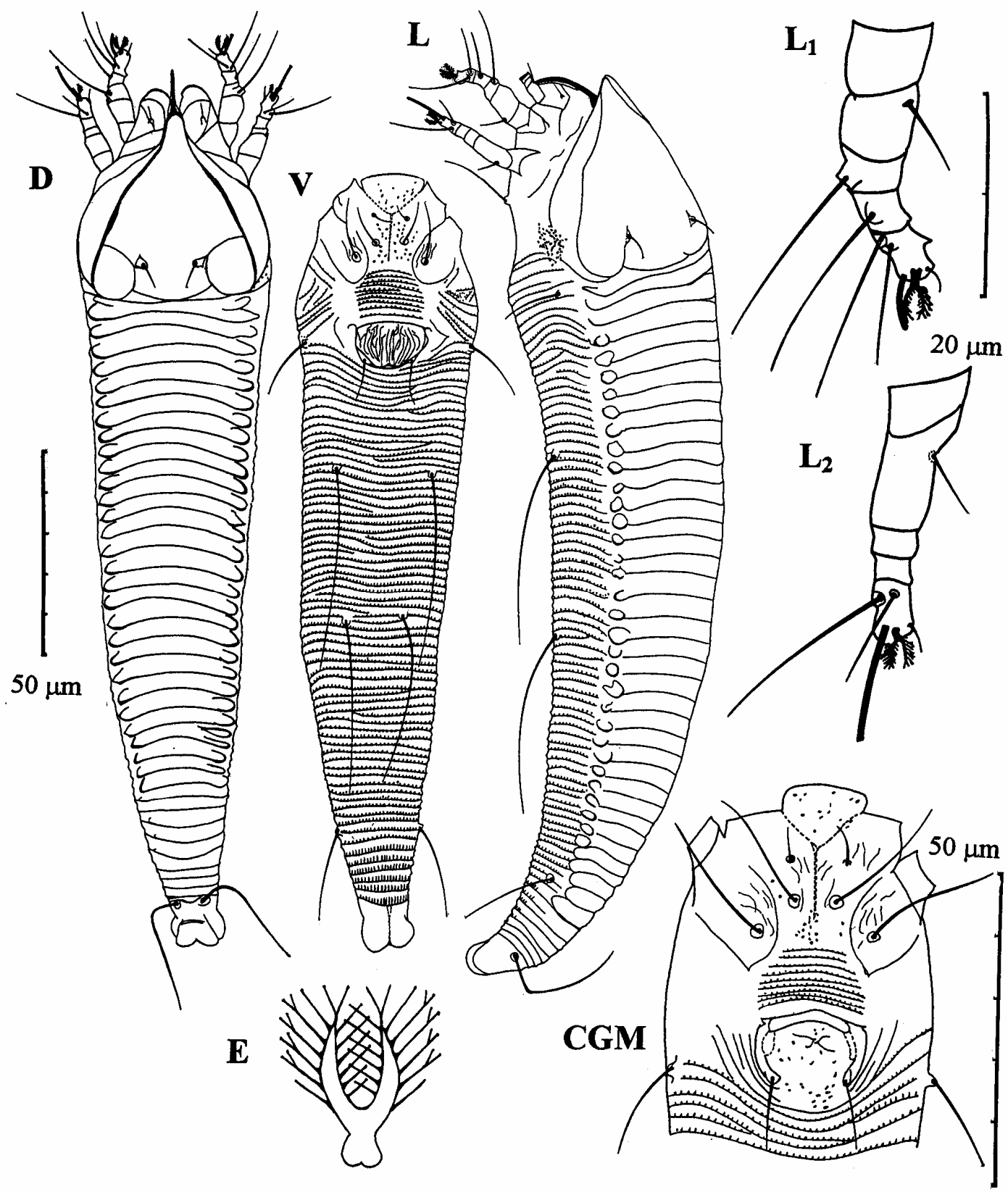

Figura 8 - Notostrix fissipes Navia \& Flechtmann, 2003- D- vista dorsal da fêmea; V- vista ventral da fêmea; L- vista lateral da fêmea; CGM- região coxigenital do macho; L1- Pernas I; L2- Pernas II; E- empódio (aumentado) 
Flechtmann, 1998; apicalmente dividido em N. jamaicae Keifer, 1970 e não-dividido em N. attenuata Keifer, 1963, N. flabellifera Mohanasundaram, 1982, N. nasutiformes Gondim Jr., Flechtmann \& Moraes, 2000 e N. butiae Gondim Jr., Flechtmann \& Moraes, 2000). Escudo dorsal típico. Pernas I com a seta da tíbia ( $l$ ’) mais longa que a seta lateral ( $\left.f t^{\prime \prime}\right)$ (pernas I com l' mais curta que $f t$ '’ nas outras espécies).

FÊMEA ( $\mathrm{n}=10)$ - Corpo fino, alongado, com 194 (163-225) de comprimento e 45 (38-51) de largura; coloração em vida branco-amarelada, com franjas de cera nas áreas laterais do opistossoma e uma linha de cera ao longo das linhas submarginais do escudo dorsal. Gnatossoma projetado para baixo, com (20) de comprimento; seta basal (ep) com 3 (3-4) de comprimento; seta antapical (d) com 4 (4-5) de comprimento; quelíceras com 14 (14-15) de comprimento; estiletes orais com (10-13) de comprimento. Escudo dorsal com 45 (44-48) de comprimento e 44 (41-47) de largura, subtriangular, liso. Setas escapulares (sc) com 6 (5-7) de comprimento, sobre tubérculos proeminentes, separados entre si por 14 (13-16), nos 3/4 posteriores do escudo, direcionando as setas para cima e para trás, levemente convergentes; setas não alcançando a margem posterior do escudo. Desenho do escudo consiste em um par de linhas submarginais formando dois lados de um triângulo isóscele, e um par de linhas curvadas, as quais formam duas células ou arcos nos ângulos látero-posteriores do escudo; uma linha transversal arqueada próxima à margem posterior do escudo une as células. Lobo frontal subtriangular, arredondado apicalmente, estende-se sobre o rostro, com 7 (7-9) de comprimento, base com 7 (5-10) de largura. Pernas não apresentam seta no genu II. Pernas I com 23 (22-25) de comprimento; fêmur com 8 (8-9) de comprimento, seta femural $(b v)$ com 8 (6-10) de comprimento; genu com 4 (3-4) de comprimento, seta do genu (l’') com 19 (15-19) de comprimento; tíbia com 4 de comprimento, seta da tíbia (l') com 13 (12-14) de comprimento; tarso com 5 (4-5) de comprimento, seta lateral (ft'’) com 12 (11-12) de comprimento, seta dorsal ( $f t^{\prime}$ ') com 10 (9-12) de comprimento, seta unguinal $\left(u^{\prime}\right)$ com 3 (2-3) de comprimento, solenídio com 4 de comprimento; empódio com 5 (4-5) de comprimento, bipartido, com dois ramos verticais, ambos com 7 (6-7) raios. Pernas II com 21 (20-23) de comprimento; fêmur com 7 (7-9) de 
comprimento, bv com 10 (7-10) de comprimento; genu com 2 (2-4) de comprimento, l", ausente; tíbia com 3 (3-4) de comprimento; tarso com 5 (5-6) de comprimento, ft'” com 16 (13-17) de comprimento, ft' com 7 (5-8) de comprimento, u' com 3 (2-3) de comprimento, solenídio com 9 (9-10) de comprimento; empódio com 4 (4-5) de comprimento, como nas pernas I, e com 6 (5-6) raios. Coxas com alguns grânulos; linhas longitudinais delicadas nas coxas II. Coxas fundidas e contínuas com o hipostômio. Linha esternal delicada, interna, com 12 (12-13) de comprimento. Setas coxais $1(1 b)$ com 4 (4-5) de comprimento, separadas por $8(6-8)$; setas coxais 2 (1a) com 14 (14-20) de comprimento, separadas por 7 (5-8); setas coxais 3 (2a) com 20 (1820) de comprimento, separadas por 17 (14-19). Nove (9-13) semi-anéis coxigenitais, microtuberculados. Epigínio com 18 (18-20) de largura e 12 (12-14) de comprimento, com 19 (14-19) linhas longitudinais sinuosas, curvadas e algumas linhas curtas irregulares na região anterior do epigínio, estendendo-se sobre todo o epigínio; seta genital (3a) com $11(10-12)$ de comprimento. Opistossoma com 39 (38-44) anéis dorsais, lisos, com uma depressão central larga; 67 (67-76) anéis ventrais, com microtubérculos pequenos, localizados um pouco à frente da borda posterior dos anéis, mais alongados no telessoma. Seta lateral $\left(c_{2}\right)$ com 17 (14-17) de comprimento, sobre o anel $1(0-2)$. Setas ventrais $1(d)$ com 50 (47-53) de comprimento, separadas por 23 (2226) e por 30 (28-36) microtubérculos, sobre o anel 14-15 (14-19); setas ventrais 2 (e) com 44 (44-46) de comprimento, separadas por 13 (13-15) e por 18 (15-24) microtubérculos, sobre o anel 32-33 (32-40); setas ventrais 3 (f) laterais, com 23 (23) de comprimento, separadas por 20 (16-20) e por 26 (26-34) microtubérculos, sobre o anel 60-61 (60-69). Seta caudal $\left(h_{2}\right)$ com 30 (27-34) de comprimento; seta acessória $\left(h_{1}\right)$ ausente.

MACHO - (n=5) Menor do que a fêmea, com 163-184 de comprimento e 36-41 de largura. Gnatossoma com 20 de comprimento; seta ep com 3-4 de comprimento; $d$ com 5-8 de comprimento; quelíceras com 13-15 de comprimento; estiletes orais com 11 de comprimento. Escudo dorsal com 42-46 de comprimento e 33-41 de largura; sc com 5-7 de comprimento, sobre tubérculos separados entre si por 12-14. Lobo frontal com 7- 
8 de comprimento, base com 6-7 de largura. Pernas como na fêmea. Pernas I com 23-25 de comprimento; fêmur com 8-9 de comprimento, $b v$ com 6-8 de comprimento; genu com 3-4 de comprimento, l' com 16-19 de comprimento; tíbia com 4-5 de comprimento, l' com 11-14 de comprimento; tarso com 4-5 de comprimento, ft', com 10-12 de comprimento, $f t$ ' 11-12 de comprimento, $u$ ' com 2-3 de comprimento, solenídio com 4-5 de comprimento; empódio com 4-5 de comprimento, como na fêmea, com 5 raios. Pernas II com 20-23 de comprimento; fêmur com 7-9 de comprimento, bv com 7-10 de comprimento; genu com 3 de comprimento; tíbia com 3-4 de comprimento; tarso com 5-6 de comprimento, $f t^{\prime \prime}$ ' com 12-14 de comprimento, ft' com 5-7 de comprimento, $u^{\prime}$ com 2-3 de comprimento, solenídio com 8-9 de comprimento; empódio com 4 de comprimento e com 5 raios. Coxas com poucos grânulos; linhas longitudinais delicadas sobre as coxas I e II. Coxas I fundidas e contínuas com hipostômio. Linha esternal interna, com 11-12 de comprimento; $1 b$ com 4-5 de comprimento, separadas por 6-8; 1 a com 20-21 de comprimento, separadas por 5-6; 2 a com 20-25 de comprimento, separadas por 14-17; 8-9 semi-anéis coxigenitais microtuberculados. Genitália com 1416 de largura e 13-14 de comprimento, ornamentado com grânulos, papilas como no desenho; 3a com 10-13 de comprimento. Opistossoma com 36-41 anéis dorsais; 60-70 anéis ventrais. Seta $c_{2}$ com 13-17 de comprimento, sobre o anel 1-4. Setas $d$ com 42-50 de comprimento, separadas por 17-20 e por 20-31 microtubérculos, sobre o anel 11-16; $e$ com 38-46 de comprimento, separadas por 11-12 e por 12-17 microtubérculos, sobre o anel 27-35; setas $f$ laterais, com 18-21 de comprimento, separadas por 16-19 e por 24-31 microtubérculos, sobre o anel 53-63. Seta $h_{2}$ com 46-51 de comprimento; $h_{1}$ ausente.

MATERIAL TIPO - Holótipo fêmea, 31 parátipos fêmeas e 14 parátipos machos, em 9 preparações microscópicas, 16 de janeiro, 18 de Abril e 12 de outubro de

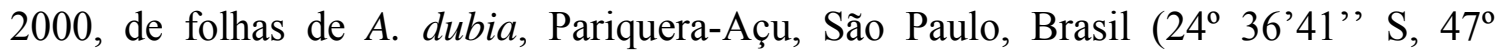
53'23' W), coletados por D. Navia e L.V.F da Silva, na Coleção Acarológica do Setor de Zoologia, Departamento de Entomologia, Fitopatologia e Zoologia Agrícola da ESALQ-USP, Piracicaba, SP, Brasil. 
RELAÇÃO COM HOSPEDEIRO - ácaro vagrante coletado na superfície inferior de folhas de A. dubia. Facilmente vistos como listras de cera branca.

ETIMOLOGIA - a designação específica fissipes é derivada do latim fissus (partido) e do latim pes (pés), referindo-se aos empódios divididos.

\section{Notostrix longiseta Navia \& Flechtmann, 2003}

(Figura 9)

DIAGNOSE - Notostrix longiseta Navia \& Flechtmann, 2003b (Phyllocoptinae, Phyllocoptini) difere de todas as demais espécies de Notostrix até então descritas por apresentar uma longa seta escapular, a qual alcança o $4^{\circ}$ anel dorsal (sc não alcançando este anel nas demais espécies). Desenho do escudo típico. Epigínio com grânulos na região anterior, como em $N$. nasutiformes, entretanto em $N$. longiseta os grânulos ocupam unicamente a porção $1 / 3$ anterior e as linhas longitudinais ocupam os 2/3 posteriores ( $N$. nasutiformes com grânulos na metade proximal e linhas longitudinais na metade distal). Juntamente com N. trifida Navia \& Flechtmann, 2003 são as menores espécies de Notostrix conhecidas.

FÊMEA (n=10) - Corpo fusiforme, com 173 (150-181) de comprimento e 46 (45-50) de largura; coloração em vida branco-amarelada. Faixas de cera ao longo das linhas medianas e submarginais e na margem posterior do escudo dorsal; estreitas faixas de cera nas áreas laterais do opistossoma. Gnatossoma projetado para baixo, com (2122) de comprimento; seta basal (ep) com 4 (3-4) de comprimento; seta antapical (d) com 6 (5-6) de comprimento; quelíceras com 15 (15-17) de comprimento; estiletes orais com (12-14) de comprimento. Escudo dorsal com 42 (41-44) de comprimento e 44 (4046) de largura, subtriangular, liso. Setas escapulares (sc) com 20 (17-20) de comprimento (alcançando o $4^{\mathrm{o}}$ anel opistossomal dorsal), sobre tubérculos separados 


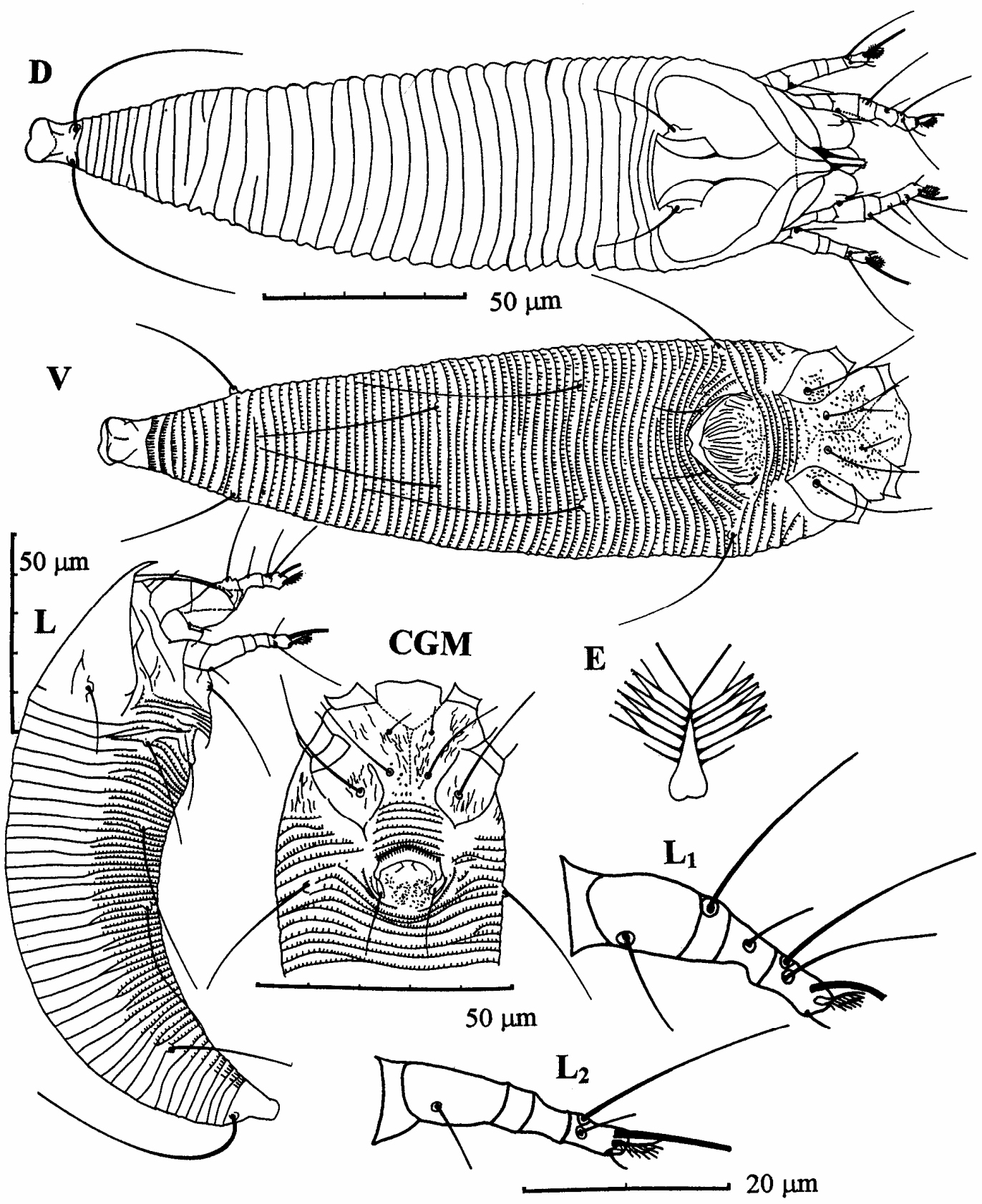

Figura 9 - Notostrix longiseta Navia \& Flechtmann, 2003 - D- vista dorsal da fêmea; V- vista ventral da fêmea; L- vista lateral do macho; CGM- região coxigenital do macho; L1- Pernas I; L2- Pernas II; E- empódio (aumentado) 
entre si por 16 (16-18), direcionados para cima e para trás, levemente divergentes, inseridos na região dos 4/5 posteriores do escudo. Desenho do escudo consiste em uma linha submarginal, paralela à margem do escudo; duas linhas medianas sinuosas estendendo-se a partir da linha submarginal ântero-posterior para a margem posterior do escudo, bifurcada posteriormente e formando duas células alongadas na região entre as bases dos tubérculos; duas linhas transversais convexas paralelas à margem mediana posterior do escudo. Lobo frontal subtriangular, arredondado apicalmente, estendendo-se sobre o rostro, com 8 (7-9) de comprimento, base com 13 (12-13) de largura. Pernas não apresentam a seta do genu II. Pernas I com 24 (24-27) de comprimento; fêmur com 9 (9-10) de comprimento, seta femural (bv) com 10 (9-12) de comprimento; genu com 4 de comprimento, seta do genu (l’’) com 17 (17-20) de comprimento; tíbia com 5 (5-6) de comprimento, seta da tíbia (l') com 6 (6-7) de comprimento; tarso com 5 (5-6) de comprimento, seta lateral ( $f t^{\prime}$ ') com 19 (17-20) de comprimento, seta dorsal ( $\left.f t^{\prime}\right)$ com 13 (13-15) de comprimento, seta unguinal ( $\left.u^{\prime}\right)$ com 2 (2-3) de comprimento, solenídio com 6 (5-7) de comprimento; empódio com 5 de comprimento e com 7 (6-7) raios. Pernas II com 23 (22-26) de comprimento; fêmur com 8 (8-9) de comprimento, bv com (9-12) de comprimento; genu com 3 (3-4) de comprimento, l' ausente; tíbia com 4 de comprimento; tarso com 5 (5-6) de comprimento, ft'” com 20 (19-22) de comprimento, ft' com 4 (4-5) de comprimento, $u^{\prime}$ com 3 (2-3) de comprimento, solenídio com 11 de comprimento; empódio com 4 (4-5) de comprimento, 6 raios. Coxas com grânulos, fundidas e contínuas com o hipostômio. Linha esternal clara, interna, com 9 (7-9) de comprimento. Setas coxais 1 (1b) com 8 (6-9) de comprimento, separadas por 7 (7-8); setas coxais 2 (1a) com 20 (16-20) de comprimento, separadas por 6 (6-7); setas coxais 3 (2a) com 26 (26-30) de comprimento, separadas por 23 (23-31); 6 (6-7) semi-anéis coxigenitais, microtuberculados. Epigínio com 20 (18-23) de largura e 17 (15-17) de comprimento, com 16 (15-16) linhas longitudinais, região basal com grânulos; seta genital (3a) com 12 (11-12) de comprimento. Opistossoma com uma depressão mediana larga, com 35 (35-38) anéis dorsais, lisos, lateralmente lisos e arredondados; 57 (57-61) anéis ventrais, com microtubérculos levemente alongados, posicionados à frente da borda posterior dos anéis, mais alongados nos 3 anéis posteriores. Seta lateral $\left(c_{2}\right)$ com 
28 (28-33) de comprimento, sobre o anel 2 (0-2). Setas ventrais 1 (d) com 43 (43-51) de comprimento, separadas por 25 (24-28) e por 29 (23-31) microtubérculos, sobre o anel 15-16 (13-16); setas ventrais 2 (e) com 40 (34-40) de comprimento, separadas por 16 (14-17) e por 14 (14-21) microtubérculos, sobre o anel 29-30 (27-31); setas ventrais $3(f)$ laterais, com 29 (27-29) de comprimento, separadas por 21 (20-25) e por 21 (21-27) microtubérculos, sobre o anel 49-50 (47-53). Seta caudal $\left(h_{2}\right)$ com (45-56) de comprimento; seta acessória $\left(h_{1}\right)$ ausente.

MACHO - (n=5) Menor que a fêmea, com 131-161 de comprimento e 38-41 de largura. Gnatossoma com 22-23 de comprimento; ep com 3-4 de comprimento; $d$ com 9-10 de comprimento; quelíceras com 14-18 de comprimento; estiletes orais com 12-13 de comprimento. Escudo dorsal com 36-38 de comprimento e 36-40 de largura; sc com 11-12 de comprimento, sobre tubérculos separados entre si por 12-15. Lobo frontal com 6-8 de comprimento, base com 10-11 de largura. Pernas como na fêmea. Pernas I com 23-28 de comprimento; fêmur com 9-10 de comprimento, bv com 8-10 de comprimento; genu com 4 de comprimento, l"' com 13-17 de comprimento; tíbia com 4-5 de comprimento, seta da tíbia l' com 5-6 de comprimento; tarso com 5-6 de comprimento, $f t$ '” com 14-15 de comprimento, $f t$ ' com 10-12 de comprimento, $u$ ' com 2 de comprimento, solenídio com 7 de comprimento; empódio com 4-5 de comprimento, como na fêmea e com 5-6 raios. Pernas II com 22-24 de comprimento; fêmur com 9 de comprimento, $b v$ com 7-9 de comprimento; genu com 3-4 de comprimento; tíbia com 4 de comprimento; tarso 5 com de comprimento, $f t$ ' ' com 15-17 de comprimento, $f t$ ' com 4 de comprimento, $u$ ' com 2 de comprimento, solenídio com 8-9 de comprimento; empódio com 4 de comprimento e com 5-6 raios. Coxas com linhas delicadas curtas e grânulos na região central. Coxas como na fêmea. Linha esternal interna, com 9 de comprimento. Setas $1 b$ com 6-7 de comprimento, separadas por 7; setas $1 a$ com 18-22 de comprimento, separadas por 5-6; setas 2a com 24-27 de comprimento, separadas por 15-16; 6-7 semi-anéis coxigenitais microtuberculados. Genitália com 13 de largura e 12-13 de comprimento, com grânulos na região posterior, papilas como no desenho; seta 3a com 13-15 de comprimento. Opistossoma com 33-38 anéis dorsais; 48-53 anéis 
ventrais. Seta $c_{2}$ com 20-24 de comprimento, sobre o anel 1-3. Setas $d$ com 38-40 de comprimento, separadas por 20 e por 15-20 microtubérculos, sobre o anel 10-12; setas $e$ com 28-33 de comprimento, separadas por 11-12 e por 9-13 microtubérculos, sobre o anel 22-26; setas $f$ laterais, com 22-25 de comprimento, separadas por 20-21 e por 21-26 microtubérculos, sobre o anel 38-45. Seta $h_{2}$ com 40-49 de comprimento; seta $h_{1}$ ausente.

MATERIAL TIPO - Holótipo fêmea, 31 parátipos fêmeas e 5 parátipos machos, em 12 preparações microscópicas, 5 de julho de 2000 e 10 de maio de 2001, de folhas de Butia archeri (Glassman) Glassman (Arecaceae), Pirassununga, São Paulo, Brasil

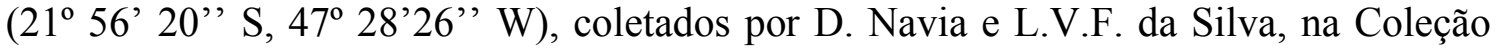
Acarológica do Setor de Zoologia, Departamento de Entomologia, Fitopatologia e Zoologia Agrícola da ESALQ-USP, Piracicaba, SP, Brasil.

RELAÇÃO COM HOSPEDEIRO - ácaro vagrante coletado na superfície inferior de folhas de B. archeri, facilmente vistos como listras de cera branca.

ETIMOLOGIA - a designação específica de longiseta is derivada do latim longus (longo) e setae (seta), referindo-se à seta relativamente longa do escudo dorsal $(s c)$.

\section{Notostrix miniseta Navia \& Flechtmann, 2003}

(Figura 10)

DIAGNOSE - Esta espécie de Notostrix apresenta setas escapulares mais curtas (2 de comprimento) que em todas as outras espécies conhecidas; tubérculos e setas podem ser cobertos por cera. Região anterior do epigínio com grânulos, como em $N$. nasutiformes e em $N$. longiseta, entretanto $N$. miniseta apresenta um padrão único de 6 (4-6) pares de linhas longitudinais que formam dois grupos relativamente separados; 


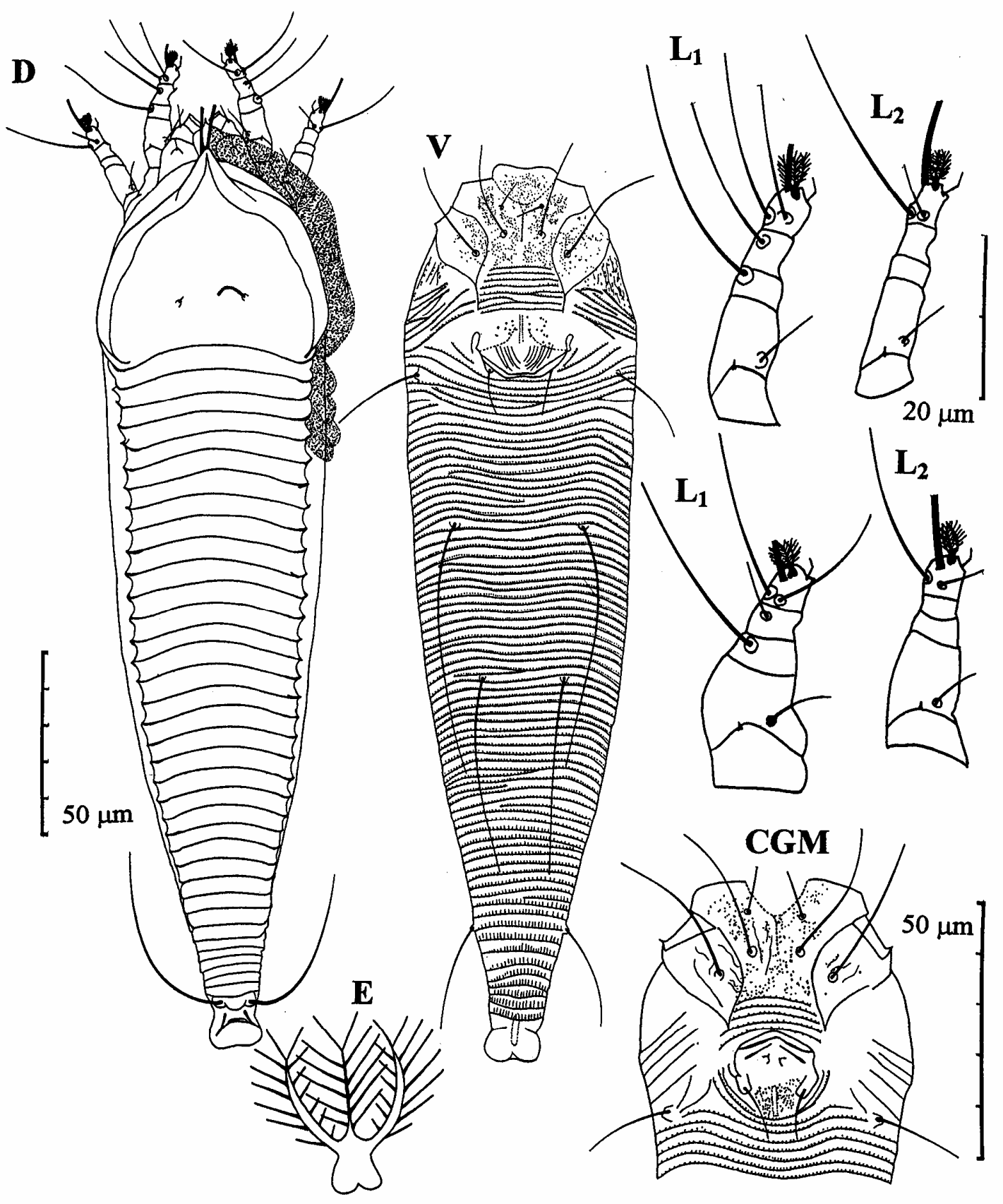

Figura 10 - Notostrix miniseta Navia \& Flechtmann, 2003- D- vista dorsal da fêmea; V- vista ventral da fêmea; CGM- região coxigenital do macho; L1- Pernas I; L2- Pernas II (a, de B. vulgaris; b, de B. setosa); Eempódio (aumentado) 
linhas distinctivamente convergentes para a região médio posterior do epigínio, e os grânulos são mais densos que nas outras duas espécies e são restritos à região ânteromediana. $N$. miniseta se assemelha a $N$. exigua por apresentar o empódio tripartido, com o ramo central apresentando 6 raios e os dois ramos laterais com 7 raios (tripartido com todos os ramos apresentando 6-7 raios em $N$. exigua), entretanto em $N$. miniseta o empódio é um pouco mais longo que em $N$. exigua.

FÊMEA ( $\mathrm{n}=5$ ) - Corpo alongado, com 227 (213-231) de comprimento e 59 (5159) de largura; coloração em vida branco-amarelada, com franjas de cera nas regiões laterais do opistossoma; uma faixa de cera circundando as margens anteriores e laterais do escudo dorsal; um tufo de cera sobre os tubérculos do escudo dorsal, o qual pode ser muito mais longo que a diminuta seta escapular ( $s c$ ). Gnatossoma projetado para baixo, com (20-23) de comprimento; seta basal (ep) com 3 (3) de comprimento; seta antapical (d) com 5 (4-5) de comprimento; quelíceras com 15 (14-15) de comprimento; estiletes orais com (10) de comprimento. Escudo dorsal com 52 (49-55) de comprimento e 56 (50-56) de largura, subtriangular, liso. Setas escapulares (sc) com 2 (2) de comprimento, sobre tubérculos distanciados entre si por 15 (14-15), direcionados para cima e para frente, levemente convergentes, inseridos nos $2 / 3$ posteriores do escudo. Desenho do escudo consiste unicamente em uma linha submarginal paralela às margens anteriores e laterais do escudo. Lobo frontal subtriangular, com a base larga, apicalmente pontudo, estendendo-se sobre o rostro, com 10 (9-10) de comprimento, base com 15 (14-15) de largura. Pernas não apresentam seta no genu II. Pernas I com 28 (25-26) de comprimento; fêmur com 11 (10-11) de comprimento, seta femural (bv) com 9 (9) de comprimento; genu com 4 (4) de comprimento, seta do genu (l') com 25 (25-26) de comprimento; tíbia com 5 (5) de comprimento, seta da tíbia (l') com 15 (15-18) de comprimento; tarso com 5 (5-6) de comprimento, seta lateral (ft') com 19 (18-20) de comprimento, seta dorsal ( $\left.f t^{\prime}\right)$ com 15 (14-16) de comprimento, seta unguinal ( $u^{\prime}$ ) com 3 (3) de comprimento, solenídio com 6 (6) de comprimento; empódio com 6 (6) de comprimento, tripartido, com dois ramos laterais que apresentam 7 (7) raios e um ramo central com com 6 (6) raios. Pernas II com 26 (23-26) de comprimento; fêmur com 11 
(11) de comprimento, seta do fêmur (bv) com 7 (6-7) de comprimento; genu com 4 (4) de comprimento, seta do genu (l') ausente; tíbia com 4 (4) de comprimento; tarso com 6 (6) de comprimento, seta lateral ( $f t^{\prime}$ ') com 20 (20-21) de comprimento, seta dorsal ( $f t^{\prime}$ ) com 8 (8) de comprimento, seta unguinal ( $\left.u^{\prime}\right)$ com 3 (3) de comprimento, solenídio com 11 (9-11) de comprimento; empódio com 6 (5-6) de comprimento, como nas pernas I, com 7 (7) raios nos ramos laterais e 6 (6) raios no ramo central. Coxas com grânulos delicados. Coxas I fundidas e contínuas com hipostômio. Linha esternal interna, com 8 (8) de comprimento. Setas coxais 1 (1b) com 6 (6-8) de comprimento separadas por 10 (9-11); setas coxais 2 (1a) com 22 (22-24) de comprimento, separadas por 8 (8); setas coxais 3 (2a) com 29 (27-29) de comprimento, separadas por 21 (21-23); 7 (7-8) semianéis coxigenitais, microtuberculados. Epigínio com 23 (22-24) de largura e 16 de comprimento, com 6 (5-6) linhas longitudinais separadas em dois grupos relativamente separados; as linhas do epigínio são distintamente convergentes para a área médioposterior; grânulos densos restritos à região ântero-central; seta genital (3a) com 12 (1112) de comprimento. Opistossoma com 37 (36-38) anéis dorsais, lisos, com uma depressão central rasa e larga; 74 (69-74) anéis ventrais, com microtubérculos pequenos e arredondados, posicionados um pouco a frentre da margem posterior dos anéis, os quais são um pouco mais alongados nos 3/4 posteriores do opistossoma. Seta lateral $\left(c_{2}\right)$ com 22 (20-24) de comprimento, sobre o anel 3-4 (3-4). Setas ventrais 1 (d) com 62 (5862) de comprimento, separados por 31 (28-33) e por 54 (42-54) microtubérculos, sobre o anel 18-20 (18-21); setas ventrais 2 (e) com 47 (41-47) de comprimento, separadas por 20 (18-20) e por 29 (23-29) microtubérculos, sobre o anel 36-38 (36-40); setas ventrais 3 (f) laterais, com 27 (27-29) de comprimento, separadas por 22 (19-22) e por 25 (22-25) microtubérculos, sobre o anel 67 (61-68). Seta caudal $\left(h_{2}\right)$ com 42 (37-42) de comprimento; seta acessória $\left(h_{1}\right)$ ausente.

MACHO - (n=3) Menor do que a fêmea, com 180-185 de comprimento e 48-55 de largura. Gnatossoma com 19-20 de comprimento; seta ep com 3-4 de comprimento; $d$ com 4-5 de comprimento; quelíceras com 14 de comprimento; estiletes orais com 10 de comprimento. Escudo dorsal com 44-49 de comprimento e 43-47 de largura. Setas sC 
com 2 de comprimento, sobre tubérculos distanciados entre si por 11-12. Lobo frontal com 8-10 de comprimento, base com 14-15 de largura. Pernas I com 24-28 de comprimento; fêmur com 9-11 de comprimento, bv com 5-7 de comprimento; genu com 4 de comprimento, l' ' com 21-23 de comprimento; tíbia com 5 de comprimento, l' com 9-10 de comprimento; tarso 6 de comprimento, $f t$ '” com 15-16 de comprimento, $f t$ ' com 12-13 de comprimento, $u^{\prime}$ com 2 de comprimento, solenídio com 5-6 de comprimento; empódio com 5 de comprimento, com 7 raios nos ramos laterais e 6 raios no ramo central. Pernas II com 22-25 de comprimento; fêmur com 9-10 de comprimento, $b v$ com 5-6 de comprimento; genu com 4 de comprimento; tíbia com 4 de comprimento; tarso com 5 de comprimento, $f t$ '” com 16-17 de comprimento, $f t$ ' com 5 de comprimento, $u$ ' com 2 de comprimento, solenídio com 8-9 de comprimento; empódio com 4-5 de comprimento. Coxas com grânulos delicados; algumas poucas linhas leves nas coxas I e II. Coxas I fundidas e contínuas com o hipostômio. Linha esternal interna, com 7 de comprimento. Setas $1 b$ com 7 de comprimento, separadas por 9-12; $1 a$ com 22 de comprimento, separadas por 7-11; $2 a$ com 26-31 de comprimento, separadas por 19-27; com 7 semi-anéis coxigenitais, microtuberculados. Genitália com 16-18 de largura e 1214 de comprimento, ornamentado com grânulos na região posterior do epigínio, papilas como no desenho; $3 a$ com 11-12 de comprimento. Opistossoma com 31-35 anéis dorsais e 70 anéis ventrais. Seta $c_{2}$ com 15-16 de comprimento, sobre o anel 5-6. Setas $d$ com 47-53 de comprimento, separadas por 21-23 e por 24 microtubérculos, sobre o anel 14-16; setas e com 9-12 de comprimento, separadas por 14-15 e por 14 microtubérculos, sobre o anel 33-34; setas $f$ laterais, com 23-25 de comprimento, separadas por 20-22 e por 26 microtubérculos, sobre o anel 60-62. Seta $h_{2}$ com 59 de comprimento; $h_{1}$ ausente.

OBSERVAÇÃO - Os espécimes coletados de Bactris setosa Mart. foram um pouco diferentes dos espécimes tipo, por apresentarem diferenças no comprimento de algumas setas. As medidas dos caracteres variáveis de 5 espécimes comparados àqueles de espécimens coletados de Bactris vulgaris Barb. Rodr. (os quais são dados entre parêntes) são: seta da tíbia (l') com 9-12 de comprimento (15-18 de comprimento); seta lateral ( $f t^{\prime \prime}$ ) com 15-16 de comprimento (18-20 de comprimento); seta dorsal ( $f t^{\prime}$ ) com 
12-13 de comprimento (14-16 de comprimento); seta lateral $\left(c_{2}\right)$ com 16-20 de comprimento (20-24 de comprimento); seta caudal $\left(h_{2}\right)$ com 50-62 de comprimento (3742 de comprimento).

MATERIAL TIPO - Holótipo fêmea, 4 parátipos fêmeas, em 2 preparações microscópicas, 11 de janeiro de 2001, de folhas de B. vulgaris, Pariquera-Açu, São

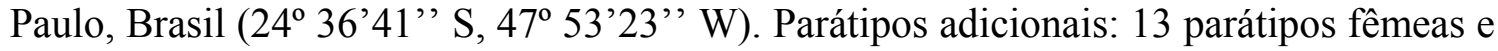
3 parátipos machos, em 2 preparações microscópicas, 16 de janeiro e 02 de agosto de 2000, de folhas de B. setosa, coletados por D. Navia e L.V.F. da Silva, na Coleção Acarológica do Setor de Zoologia, Departamento de Entomologia, Fitopatologia e Zoologia Agrícola da ESALQ-USP, Piracicaba, SP, Brasil.

RELAÇÃO COM HOSPEDEIRO - ácaro vagrante coletado na superfície inferior de folhas de B. vulgaris e B. setosa. Os ácaros foram facilmente vistos como listras de cera branca.

ETIMOLOGIA - A designação específica miniseta is derivada do grego minys (pequeno) e do latim setae (seta), referindo-se à seta diminuta do escudo dorsal ( $S C$ ).

\section{Notostrix trifida Navia \& Flechtmann, 2003}

(Figura 11)

DIAGNOSE - Notostrix trifida Navia \& Flechtmann, 2003b difere de todas as outras espécies do gênero até então descritas por apresentar um empódio tripartido, composto por dois ramos laterais, cada um com 8 raios, e um ramo central sem raios, mas apicalmente bifurcado (tripartido em $N$. exigua entretanto com o ramo central apresentando 6-7 raios). Desenho do escudo típico. Seta femural (bv) angulada nas 


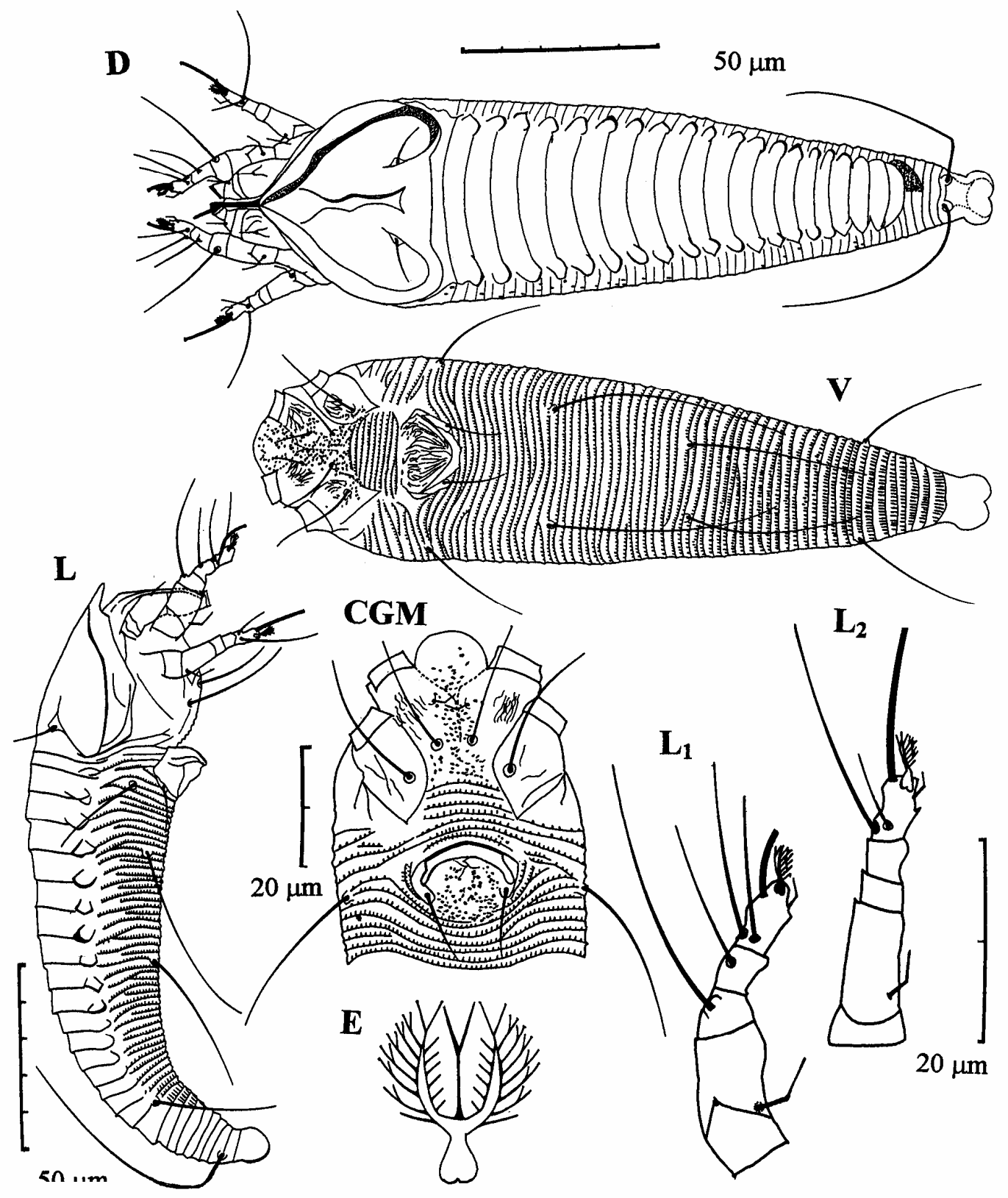

$50 \mu \mathrm{m}$

Figura 11 - Notostrix trifida Navia \& Flechtmann, 2003- D- vista dorsal da fêmea; V- vista ventral da fêmea; CGM- região coxigenital do macho: L1- Pernas I: L2- Pernas II: E- empódio (aumentado) 
pernas I e II (não angulada nas outras espécies). Solenídio II 2.5 (2.6-3) vezes mais longo que o comprimento do empódio II (duas vezes ou menos nas outras espécies).

FÊMEA ( $\mathrm{n}=10)$ - Corpo fusiforme, com 178 (163-186) de comprimento e 50 (43-50) de largura; coloração em vida branco-amarelada, com franjas de cera nas áreas laterais dos anéis do opistossoma e uma faixa de cera ao longo das linhas medianas e submarginais do escudo dorsal. Gnatossoma projetado para baixo, com 20 (20-23) de comprimento; seta basal (ep) com (3-4) de comprimento; seta antapical (d) com 4 (3-5) de comprimento; quelíceras com 15 (14-16) de comprimento; estiletes orais com 13 (1113) de comprimento. Escudo dorsal subtriangular, liso, com 39 (39-43) de comprimento e 43 (36-43) de largura. Setas escapulares (sc) com 12 (11-12) de comprimento, sobre tubérculos distanciados entre si por 16 (14-16), direcionados para cima e para trás, levemente divergentes, inseridos nos 3/4 posteriores do escudo; as SC são mais longas do que a distância entre os tubérculos e a margem posterior do escudo. Desenho do escudo consiste em uma linha submarginal, paralela às margens anteriores e laterais do escudo, curvadas para dentro na região látero-posterior e unindo a base dos tubérculos; duas linhas medianas sinuosas estendem-se dos $2 / 5$ até os $4 / 5$ posteriores do escudo, unidas caudalmente por uma linha transversal curvada. Lobo frontal subtriangular, arredondado, estendendo-se sobre o rostro, com 6 (5-6) de comprimento, base com 5 (57) de largura. Pernas não apresentam seta no genu II. Pernas I com 27 (26-28) de comprimento; fêmur com 9 (9-10) de comprimento, seta femural (bv) angulada, com 9 (7-10) de comprimento; genu com 4 (3-4) de comprimento, seta do genu (l') com 24 (21-24) de comprimento; tíbia com 5 (5-6) de comprimento, seta da tíbia (l') com 13 (11-13) de comprimento; tarso com 6 (6-7) de comprimento, seta lateral ( $f t^{\prime}$ ') com 15 (14-16) de comprimento, seta dorsal ( $\left.f t^{\prime}\right)$ com 11 (11-12) de comprimento, seta unguinal ( $\left.u^{\prime}\right)$ com 4 (3-4) de comprimento, solenídio com 6 (6-7) de comprimento; empódio com 5 (5-6) de comprimento, tripartido, com dois ramos laterais com 8 (7-8) raios e um ramo central sem raios, mas bifurcado apicalmente como no desenho. Pernas II com 24 (2326) de comprimento; fêmur com 8 (8-10) de comprimento, seta femural (bv) como nas pernas I, com 9 (7-9) de comprimento; genu com 3 (3-4) de comprimento, seta do genu 
(l') ausente; tíbia com 4 (3-4) de comprimento; tarso com 6 (6-7) de comprimento, seta lateral (ft') com $20(20-21)$ de comprimento, seta dorsal ( $\left.f t^{\prime}\right)$ com 6 (6-8) de comprimento, seta unguinal ( $\left.u^{\prime}\right)$ com 4 (3-4) de comprimento, solenídio com 13 (12-13) de comprimento; empódio com 5 (4-5) de comprimento, ramos laterais com 6 (6-7) raios, como nas pernas I. Coxas com grânulos e linhas sinuosas delicadas. Coxas I fundidas e contínuas com o hipostômio. Linha esternal delicada, interna, com 10 (9-10) de comprimento. Setas coxais 1 (1b) seta unguinal ( $\left.u^{\prime}\right)$ com 7 (6-8) de comprimento, separadas por 7 (6-8); setas coxais 2 (1a) com 18 (16-22) de comprimento, separadas por 7 (6-7); setas coxais 3 (2a) com (22-27) de comprimento, separadas por 20 (18-20). Nove (8-10) semi-anéis coxigenitais, microtuberculados. Epigínio subtriangular, com 21 (19-21) de largura e 15 (13-15) de comprimento, com 15 (14-16) linhas longitudinais sinuosas, curvadas, levemente convergentes, anteriormente alternadas com linhas irregulares curtas; seta genital (3a) com 12 (12-14) de comprimento. Opistossoma com 28 (25-28) anéis dorsais largos, lisos, com uma larga depressão central; os 4-5 anéis caudais são estreitos e contínuos com os anéis ventrais; 57 (55-60) anéis ventrais, com microtubérculos pequenos, posicionados um pouco à frente da borda posterior dos anéis, gradualmente mais alongados do opistossoma médio para o posterior; na maioria dos espécimes os anéis ventrais estreitos estendem-se látero-dorsalmente e podem ser vistos em uma vista dorsal. Seta lateral $\left(c_{2}\right)$ com 28 (27-32) de comprimento, sobre o anel 1 (12). Setas ventrais $1(d)$ com 54 (44-54) de comprimento, separadas por 28 (24-28) e por 43 (33-45) microtubérculos, sobre o anel 12-13 (11-16); setas ventrais 2 (e) com 41 (3846) de comprimento, separadas por 18 (14-18) e por 24 (19-24) microtubérculos, sobre o anel 27-29 (27-33); setas ventrais 3 (f) laterais, com 32 (27-34) de comprimento, separadas por 24 (19-25) e por 30 (25-30) microtubérculos, sobre o anel 49 (47-53). Seta caudal $\left(h_{2}\right)$ com 44 (44-49) de comprimento; seta acessória $\left(h_{1}\right)$ ausente.

MACHO - $(n=5)$ Menor do que a fêmea, com 135-151 de comprimento e 34-40 de largura. Gnatossoma com 18-21 de comprimento; seta ep com 3-4 de comprimento; seta $d$ com 4-6 de comprimento; quelíceras com 16 de comprimento; estiletes orais com 11-12 de comprimento. Escudo dorsal com 36-38 de comprimento e 30-34 de largura. 
Setas SC com 9-10 de comprimento, sobre tubérculos distanciados entre si por 12-13. Lobo frontal com 4-6 de comprimento, base com 4-6 de largura. Pernas I com 24-27 de comprimento; fêmur com 8-9 de comprimento, $b v$ com 9-10 de comprimento, anguladas; genu com 4 de comprimento, l', com 19-20 de comprimento; tíbia com 4-5 de comprimento, l' com 10-12 de comprimento; tarso com 6 de comprimento, ft' ' com 1215 de comprimento, $f t$ ' com 9-12 de comprimento, $u$ ' com 3-4 de comprimento, solenídio com 5-6 de comprimento; empódio com 4-5 de comprimento, como na fêmea, ramos laterais com 6-7 raios. Pernas II com 21-24 de comprimento; fêmur com 8-9 de comprimento, $b v$ com 5-8 de comprimento, como nas pernas I; genu com 3-4 de comprimento; tíbia com 3-4 de comprimento; tarso com 5-6 de comprimento, $f t$ '” com 17-18 de comprimento, $f t^{\prime}$ com 6-10 de comprimento, $u$ ' com 3 de comprimento, solenídio com 11-12 de comprimento; empódio com 4 de comprimento, ramos laterais com 5-6 raios. Coxas com grânulos e linhas sinuosas delicadas. Linha esternal interna, com 8-10 de comprimento. Setas $1 b$ com 4-5 de comprimento, separadas por 5-7; $1 a$ com 16-21 de comprimento, separadas por 4-6; $2 a$ com 19-25 de comprimento, separadas por 14-18; 8-10 semi-anéis coxigenitais, microtuberculados. Genitália com 13-14 de largura e 12 de comprimento, com grânulos, papilas como no desenho; 3a com 10-12 de comprimento. Opistossoma com 24-25 anéis dorsais e 48-57 anéis ventrais. Seta $c_{2}$ com 20-24 de comprimento, sobre o anel 0-2; $d$ com 43-46 de comprimento, separados por 21-22 e por 31-34 microtubérculos, sobre o anel 9-13; e com 36-40 de comprimento, separados por 12 e por 12-19 microtubérculos, sobre o anel 22-28; $f$ laterais com 27-29 de comprimento, separadas por 18-19 e por 21-26 microtubérculos, sobre o anel 41-49. Seta $h_{2}$ com 47-51 de comprimento; $h_{1}$ ausente.

MATERIAL TIPO - Holótipo fêmea, 19 parátipos fêmeas e 6 parátipos machos, em 8 preparações microscópicas, 29 de fevereiro de 2001, de folhas de Lytocaryum hoehnei (Burret) Toledo (Arecaceae), Morro Grande, Cotia, São Paulo, Brasil (23 43’ S, $46^{\circ} 51^{\prime}$ W), coletados por D. Navia e L.V.F. da Silva, na Coleção Acarológica do Setor de Zoologia, Departamento de Entomologia, Fitopatologia e Zoologia Agrícola da ESALQ-USP, Piracicaba, SP, Brasil. 
RELAÇÃO COM HOSPEDEIRO - ácaro vagrante coletado na superfície inferior de folhas de L. hoehnei. Facilmente vistos como faixas de cera branca.

ETIMOLOGIA - A designação específica trifida is composta pelo latim tri (três) e pelo latim findo (dividido), referindo-se ao empódio tripartido.

\section{Notostrix vazquezae Navia \& Flechtmann, 2003}

(Figura 12)

DIAGNOSE - Notostrix vazquezae Navia \& Flechtmann, 2003b é distinta de todas as outras espécies até então descritas por apresentar o epigínio estreito e longo com as linhas longitudinais em uma única banda estendendo-se por toda a área do epigínio (epigínio longo em $N$. attenuata com um padrão de linhas curvas divergentes anteriormente). Lobo frontal curto (3 (2-3) de comprimento), arredondado e liso (estendendo-se sobre o gnatossoma em todas as outras espécies). Desenho do escudo típico. Pernas I com a seta da tíbia (l') mais longa que (ou tão longa quanto) a seta

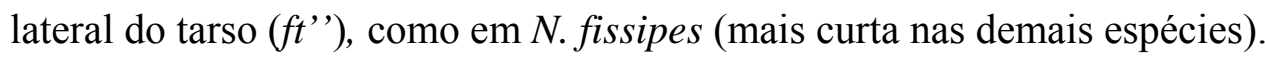

FÊMEA - (n=6) Corpo delgado, alongado, com 214 (180-214) de comprimento e 47 (38-49) de largura; coloração em vida amarelada. Produção de cera não observada. Gnatossoma projetado para baixo, com (17-20) de comprimento; seta basal (ep) com 2 (2-3) de comprimento; seta antapical $(d)$ com 4 de comprimento; quelíceras com 14 (1416) de comprimento; estiletes orais com (12) de comprimento. Escudo dorsal subtriangular, liso, com 44 de comprimento e 40 (36-43) de largura; escudo dorsal mais estreito que a porção anterior do idiosoma, flanqueado por grânulos e linhas longitudinais delicadas na região anterior. Setas escapulares (sc) com 9 (9-11) de comprimento (estendendo-se um pouco além da margem posterior do escudo), sobre tubérculos proeminentes, com 19 (15-19), direcionadas para trás, levemente divergentes, inseridas nos $4 / 5$ posteriores do escudo. Desenho do escudo consiste em linhas medianas 

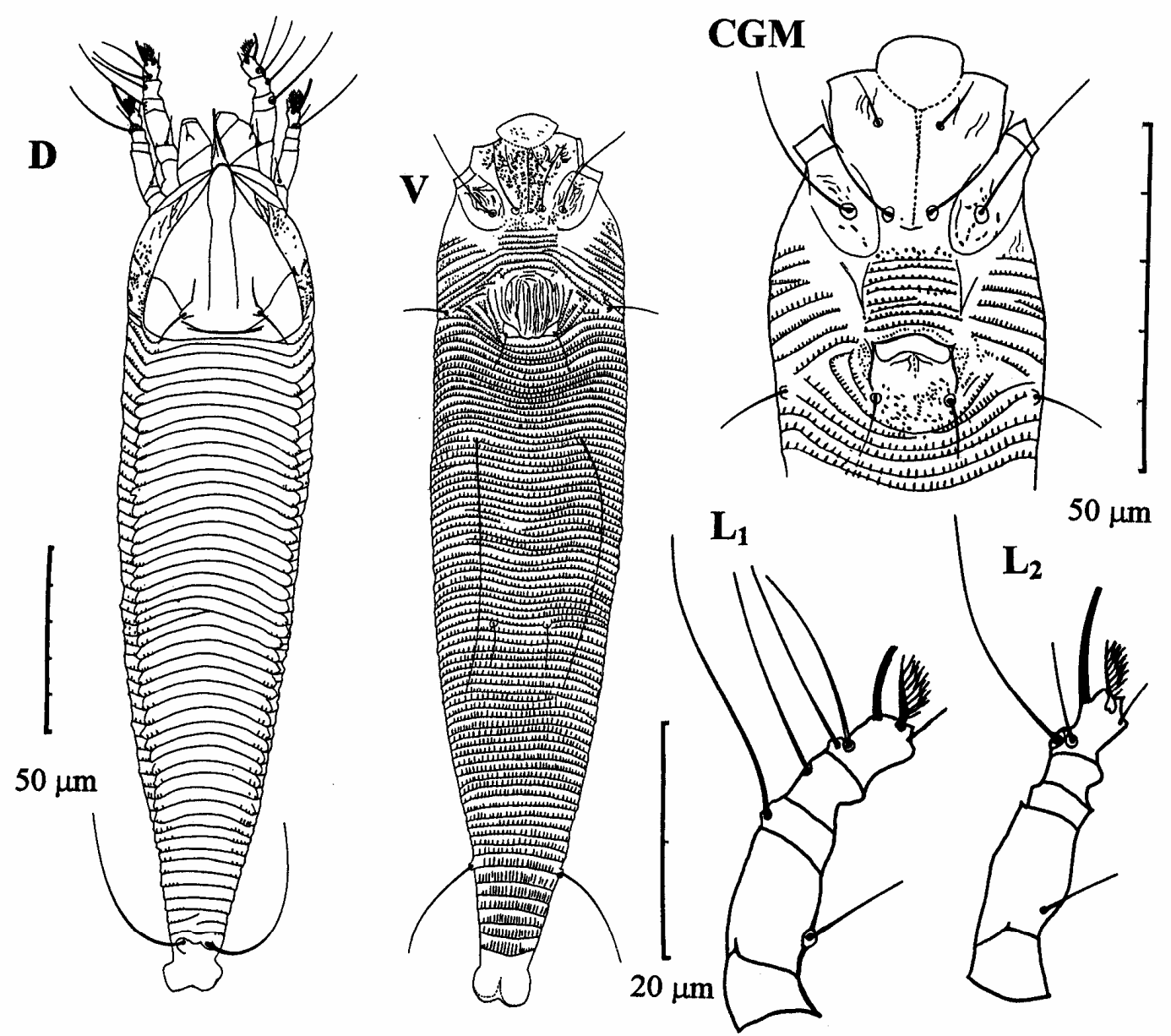

$\mathbf{L}$
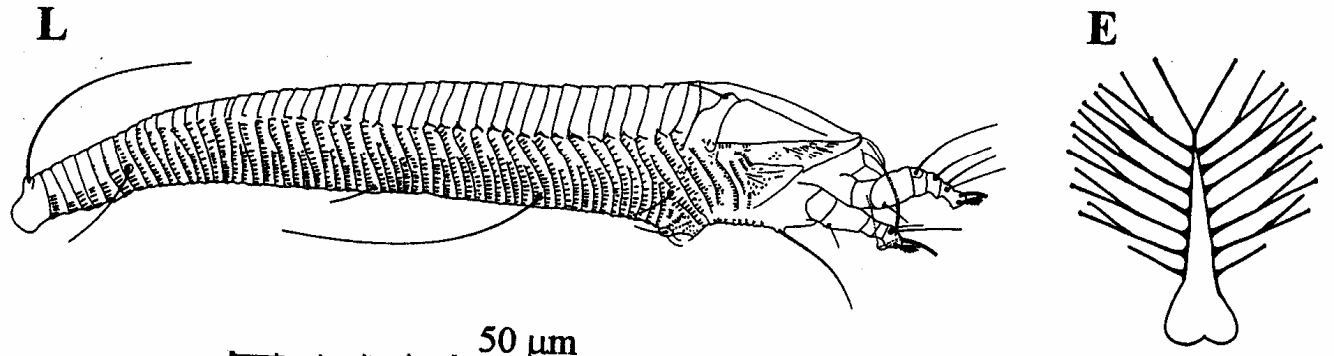

Figura 12 - Notostrix vazquezae Navia \& Flechtmann, 2003- D- vista dorsal da fêmea; V- vista ventral da fêmea; L- vista lateral do macho; CGMregião coxigenital do macho; L1- Pernas I; L2- Pernas II; E- empódio (aumentado) 
curvadas anteriormente, estendendo-se da base do lobo frontal até os 4/5 posteriores do escudo; duas linhas curtas, levemente curvadas, estendendo-se anteriormente e divergindo dos tubérculos dirsais; e uma linha transversal conspícua posterior aos tubérculos. Lobo frontal curto e arredondado, com 3 (2-3) de comprimento, base com 4 de largura. Pernas não apresentam seta no genu II. Pernas I com 27 (25-27) de comprimento; fêmur com 8 (8-10) de comprimento, seta femural (bv) com 8 de comprimento; genu com 4 de comprimento, seta do genu (l') com 21 (21-23) de comprimento; tíbia com 5 (4-5) de comprimento, seta da tíbia (l’) com 15 (13-15) de comprimento; tarso com 5 de comprimento, seta lateral ( $f t^{\prime \prime}$ ) com 14 (14-16) de comprimento, seta dorsal ( $\left.f t^{\prime}\right)$ com 13 (13-15) de comprimento, seta unguinal ( $\left.u^{\prime}\right)$ com 4 de comprimento, solenídio com 6 (6-7) de comprimento; empódio com 6 (5-6) de comprimento, não dividido, com 8 raios. Pernas II com 24 (22-25) de comprimento; fêmur 9 (9-10) de comprimento, seta femural (bv) com 6 (6-7) de comprimento; genu 3 de comprimento, seta do genu (l') ausente; tíbia com 4 (3-4) de comprimento; tarso 5 de comprimento, seta lateral ( $f t^{\prime}$ ') com 18 (16-19) de comprimento, seta dorsal ( $\left.f t^{\prime}\right)$ com 8 (8-9) de comprimento, $u$ ' com 3 (3-4) de comprimento, solenídio com 9 (8-9) de comprimento; empódio com 6 (5-7) de comprimento, como nas pernas I, com 7 (7-8) raios. Coxas com grânulos e linhas longitudinais delicadas. Coxas I fundidas e contínuas com o hipostômio. Linha esternal interna, com 14 (13-15) de comprimento. Setas coxais 1 (1b) com 8 (7-9) de comprimento, separadas por 8 (7-9); setas coxais 2 (1a) com 16 (15-20) de comprimento, separadas por 6 (5-6); setas coxais 3 (2a) com (25-28) de comprimento, separadas por 17 (15-18); setas coxais 2 (1a) quase em linha transversal com as setas coxais $3(2 a) ; 7$ (7-8) semi-anéis coxigenitais, microtuberculados. Epigínio com 19 (16-19) de largura e 18 (17-19) de comprimento, com 19 (17-19) linhas longitudinais, com algumas linhas curtas entre as linhas longas que se estendem por todo o epigínio; linhas transversais curtas, curvadas, na região anterior do epigínio; algumas linhas longitudinais laterais são curvadas basalmente em direção ao centro; seta genital (3a) com 11 (9-11) de comprimento. Opistossoma com 48 (47-51) anéis dorsais, com alguns poucos grânulos (microtubérculos? dutos de glândulas?) sobre as bordas, com ums depressão mediana larga; 72 (71-76) anéis ventrais, com microtubérculos 
alongados, localizados um pouco à frente da borda posterior dos anéis, os quais são mais alongados no telessoma (região posterior do opistossoma após a base das setas f); na maioria dos espécimes os anéis ventrais estendem-se látero-dorsalmente e podem servistos dorsalmente. Seta lateral $\left(c_{2}\right)$ com 12 (12-14) de comprimento, sobre o anel 01. Setas ventrais $(d)$ com 62 (53-62) de comprimento, separadas por 26 (23-26) e por 21 (21-30) microtubérculos, sobre o anel 16-17 (16-19); setas ventrais 2 (e) com 12 (10-12) de comprimento, separadas por 13 (12-14) e por 11 (10-12) microtubérculos, sobre o anel 39-40 (37-43); setas ventrais 3 (f) laterais, com 26 (24-30) de comprimento, separadas por 21 (16-21) e por 20 (20-26) microtubérculos, sobre o anel 66 (65-72). Seta caudal $\left(h_{2}\right)$ com 43 (40-49) de comprimento; seta acessória $\left(h_{1}\right)$ ausente.

MACHO - (n=4) Menor do que a fêmea, com 147-186 de comprimento e 36-38 de largura. Gnatossoma com 21 de comprimento; seta ep com 2 de comprimento; $d$ com 4 de comprimento; quelíceras com 15-16 de comprimento; estiletes orais com 11 de comprimento. Escudo dorsal com 36-40 de comprimento e 33-34 de largura. Setas SC com 9-10 de comprimento, sobre tubérculos separados entre si por 12-16. Lobo frontal com 2-3 de comprimento, base com 4 de largura. Pernas I com 23-28 de comprimento; fêmur com 9 de comprimento, $b v$ com 7-8 de comprimento; genu com 4 de comprimento, l', com 18-19 de comprimento; tíbia com 4-5 de comprimento, l' com 1213 de comprimento; tarso com 5-6 de comprimento, $f t$ ' ' com 12-13 de comprimento, $f t$ ' com 12-14 de comprimento, $u^{\prime}$ com 3-4 de comprimento, solenídio com 6-7 de comprimento; empódio com 6 de comprimento, como na fêmea, com 7 raios. Pernas II com 20-22 de comprimento; fêmur com 8-9 de comprimento, bv com 5-6 de comprimento; genu com 3 de comprimento; tíbia com 3-4 de comprimento; tarso com 45 de comprimento, $f t$ '’ com 14-15 de comprimento, $f t$ ' com 7-8 de comprimento, $u$ ' com 3 de comprimento, solenídio com 8-9 de comprimento; empódio com 6 de comprimento e com 6-7 raios. Coxas com linhas curvas delicadas; poucos grânulos nas coxas II, as quais são quase lisas na área central. Coxas fundidas e contínuas com o hipostômio. Linha esternal interna, com 13-14 de comprimento. Setas $1 b$ com 7-8 de comprimento, separadas por 7-8; $1 a$ com 20-21 de comprimento, separadas por 4-5; $2 a$ com 23-27 de 
comprimento, separadas por 13-15; 8-9 semi-anéis coxigenitais, microtuberculados. Genitália com 12 de largura e 12-13 de comprimento, com grânulos na região posterior, papilas como no desenho; $3 a$ com 7-9 de comprimento. Opistossoma com 42-45 anéis dorsais; 61-63 anéis ventrais. Seta $c_{2}$ com 9-11 de comprimento, sobre o anel 0-2; $d$ com 53-58 de comprimento, separadas por 18 e por 15-17 microtubérculos, sobre o anel 1315; e com 9-10 de comprimento, separadas por 9, sobre o anel 31-34; f laterais, com 2022 de comprimento, separadas por 16-17 e por 16-23 microtubérculos, sobre o anel 5557. Seta $h_{2}$ com 44-48 de comprimento; $h_{1}$ ausente.

MATERIAL TIPO - Holótipo fêmea, 5 parátipos fêmeas e 4 parátipos machos, em 3 preparações microscópicas, 17 de setembro de 2002, de folhas de Sabal sp. (Arecaceae), Chetumal, Quintana Roo, México (18 30.4’N; 88 19.7’ W), coletados por D. Navia e C. Chargoy, na Coleção Acarológica do Setor de Zoologia, Departamento de Entomologia, Fitopatologia e Zoologia Agrícola da ESALQ-USP, Piracicaba, SP, Brasil.

RELAÇÃO COM HOSPEDEIRO - ácaro vagrante coletado na superfície superior de folhas de Sabal sp..

ETIMOLOGIA - Temos o prazer de nomear esta espécie em homenagem a Dra. Maria Magdalena Vazquez Gonzalez, Acarologista, Professora Universidad de Quintana Roo (UQROO), Chetumal, México.

\section{Proartacris longior Navia \& Flechtmann, 2002}

(Figuras 13-14)

DIAGNOSE - Um Proartacris bastante alongado e atenuado, com anéis dorsais lisos e com anéis ventrais completamente microtuberculados. 


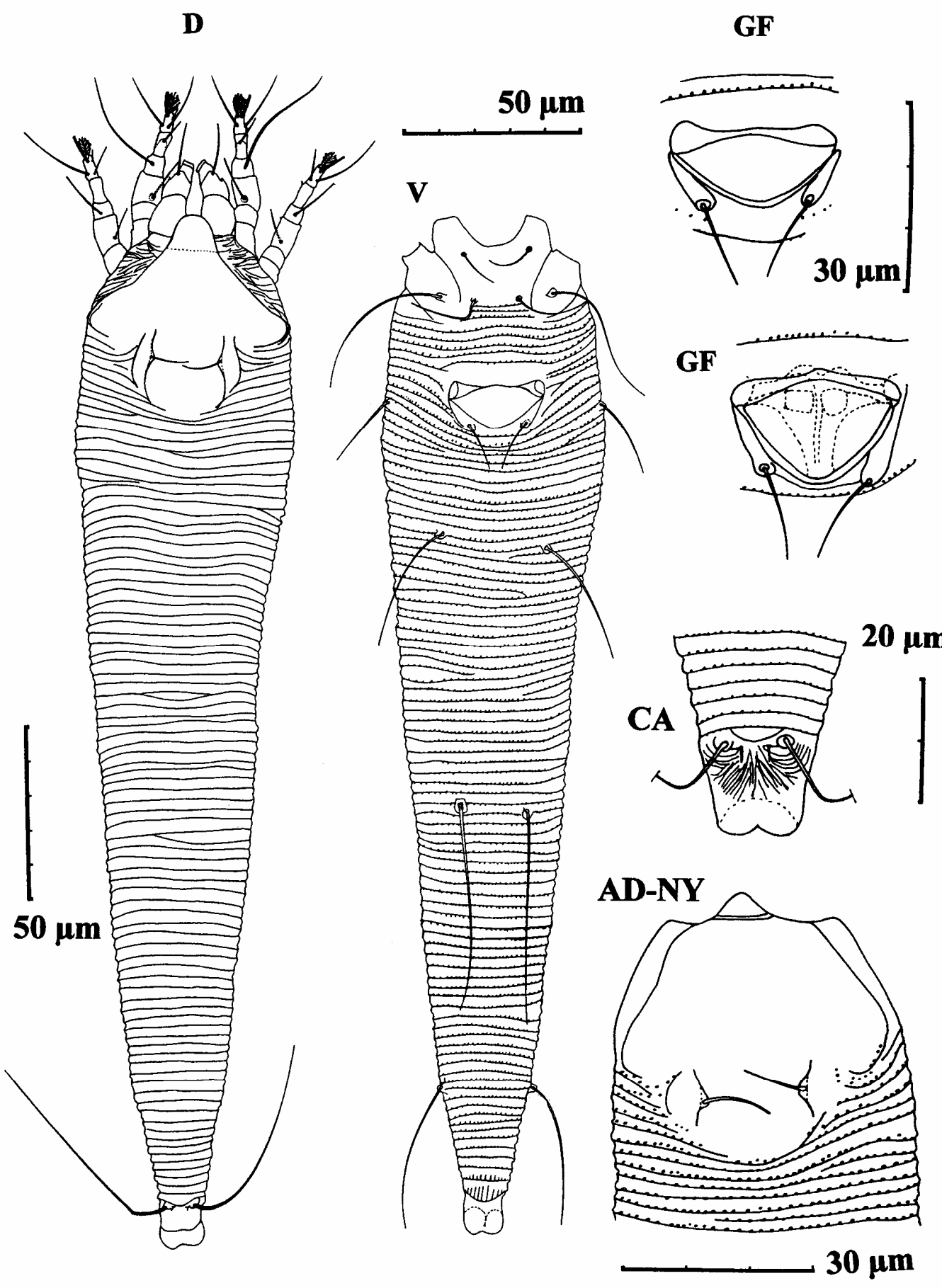

Figura 13 - Proartacris longior Navia \& Flechtmann, 2002- D- vista dorsal da fêmea; V-vista ventral da fêmea; GF-genitália da fêmea; CA- região caudal; AD-NY - região ântero-dorsal da ninfa 

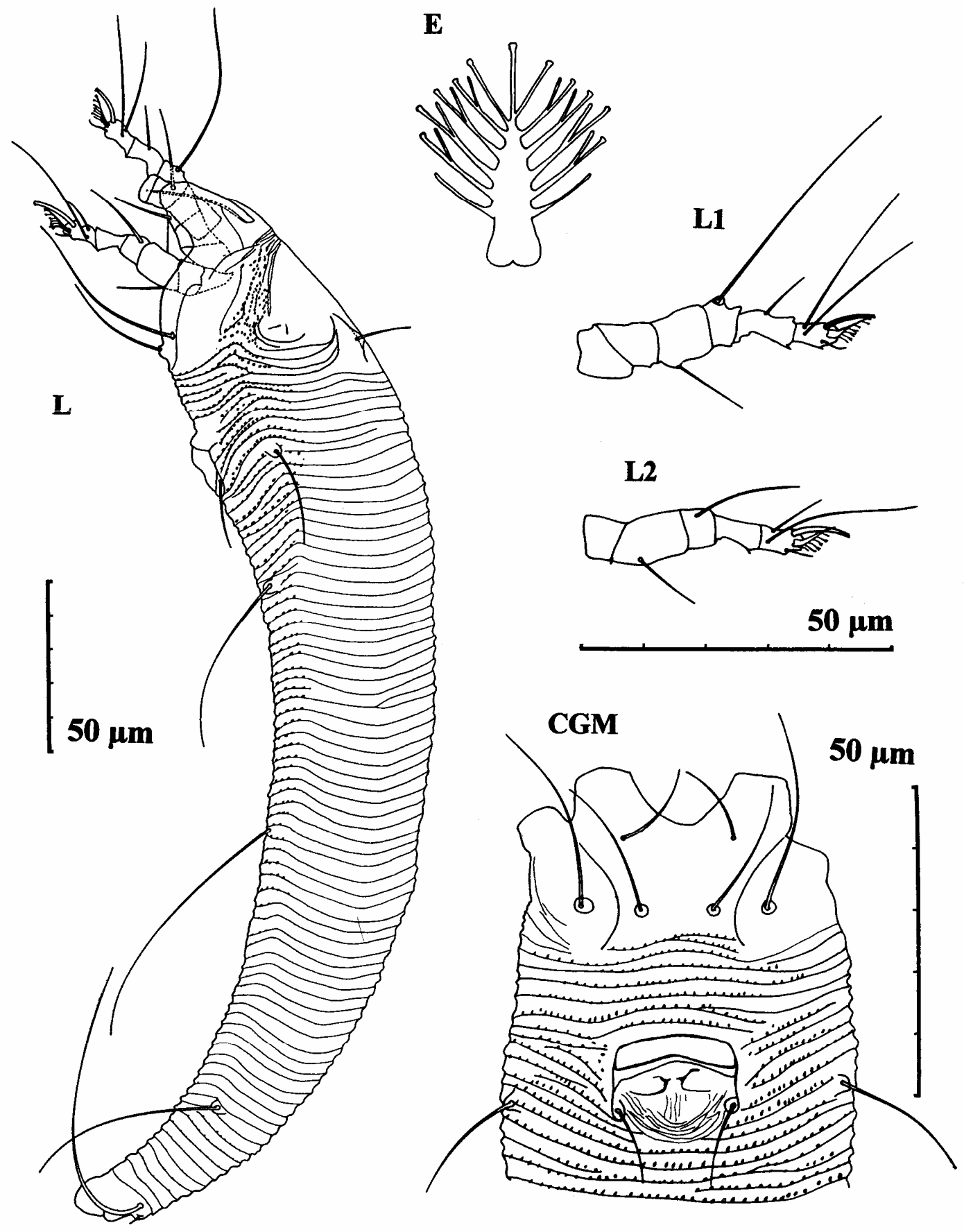

Figura 14 - Proartacris longior Navia \& Flechtmann, 2002- L- vista lateral da fêmea; CGM- região coxigenital do macho; L1- Pernas I; L2- Pernas II; E- empódio (aumentado) 
OBSERVAÇÃO - Esta é a segunda espécie do gênero Proartacris Mohanasundaram, 1984 (Eriophyinae, Eriophyini) a ser descrita e difere da espécie tipo, Proartacris pinivagrans Mohanasundaram, 1984 pelo corpo mais alongado e estreito e pela ausência de microtubérculos nos anéis dorsais do opistossoma.

De acordo com as observações de J. W. Amrine Jr. (comunicação pessoal), Proartacris longior Navia \& Flechtmann, 2002 apresenta duas características que sugerem que o mesmo pertence a Phyllocoptinae: o lobo frontal e os anéis dorsais lisos (comparados aos anéis ventrais completamente microtuberculados). Entretanto, o lobo frontal flexível está presente também no gênero Artacris Keifer, 1970 (sinonimizado com Aceria por (Amrine, 1996)); esta nova espécie é extremamente longa e atenuada (como os Eriophyinae) e alguns Eriophyinae apresentam anéis dorsais lisos, como Eriophyes emarginatae Keifer, 1939b; E. marinalni Keifer, 1939c; Aceria caryae (Keifer, 1939d) e A. calaceris Keifer, 1952.

FÊMEA - (n=10) Comprimento do corpo 270 (185-299), largura 56 (54-68), vermiforme, esbranquiçada. Gnatossoma curvado ventralmente em um ângulo obtuso, com 24 (24-31) de comprimento. Seta antapical (d) com 13 (13-18) de comprimento; quelíceras com 20 (19-21) de comprimento; estiletes orais com 15 (14-17) de comprimento. Escudo dorsal liso, com 52 (52-55) de comprimento e 51 (46-57) de largura, subtriangular, com ângulos posteriores arredondados; lobo frontal arredondado e com a base larga e flexível, com 10 (9-11) de comprimento; extensão medioposterior, com extensão equivalente a 5-6 anéis dorsais, compreendendo a região dos tubérculos dorsais. Setas escapulares do escudo dorsal (sc) com 10 (10-11) de comprimento, direcionadas para cima e para o centro, sobre tubérculos, os quais apresentam a base larga e são pouco desenvolvidos, separados entre si por 18 (18-22). Pernas com todas as setas usuais presentes. Pernas I com 31 (30-33) de comprimento; fêmur com 11 (1011) de comprimento; seta femural (bv) com 13 (11-15) de comprimento; genu com 5 (56) de comprimento; seta do genu (l”) com 32 (32-37) de comprimento; tíbia apresentando uma coroa distal de espinhos, com 7 (7-8) de comprimento; seta da tíbia (l') com 7 (6-9) de comprimento; tarso com 6 (6-7) de comprimento; seta lateral (ft”) 
com 21 (21-26) de comprimento; seta dorsal (ft') com 18 (18-24) de comprimento; seta unguinal ( $u^{\prime}$ ) com 4 (4-5) de comprimento; solenídio com 6 (6-7) de comprimento, extremidade levemente expandida e achatada; empódio com 6 (6-7) de comprimento, com 6 raios pareados e um apical não pareado. Pernas II com 31 (29-33) de comprimento; fêmur com 9 (9-11) de comprimento; seta femural (bv) com 11 (11-12) de comprimento; genu com 5 (4-5) de comprimento; seta do genu (l”) com 13 (13-18) de comprimento; tíbia com 5 (5-7) de comprimento; tarso com 6 (6-7) de comprimento; seta lateral ( $\left.f t^{\prime \prime}\right)$ com 20 (20-24) de comprimento; seta dorsal ( $\left.f t^{\prime}\right)$ com 5 (5-8) de comprimento; seta unguinal ( $\left.u^{\prime}\right)$ com 4 de comprimento, solenídio com 7 (7-9) de comprimento, como nas pernas I; empódio com 7 (6-8) de comprimento, com 6 (5-6) raios pareados mais um raio apical não pareado. Setas coxais 1 (1b) separadas por 17 (17-18), com 11 (11-12) de comprimento; setas coxais 2 (1a) separadas por 11 (10-11), com 24 (20-24) de comprimento; setas coxais 3 (2a) separadas por 28 (26-29), com 36 (36-40) de comprimento. Coxas lisas. Linha esternal ausente. Região coxiesternal com 7 (6-8) semi-anéis, microtuberculados. Últimos semi-anéis coxiesternais distintamente separados da margem anterior do epigínio. Epigínio com 25 (24-25) de largura e 12 (1218) de comprimento, liso; seta genital (3a) com 11 (11-16) de comprimento. Opistossoma com uma elevação dorso-mediana larga, pouco desenvolvida. Anéis dorsais sem microtubérculos, exceto os últimos 7-8 anéis, os quais são microtuberculados em alguns indivíduos; anéis ventrais com microtubérculos pequenos e pontiagudos, os quais tornam-se alongados nos dois últimos anéis. Seta lateral $\left(c_{2}\right)$ com 20 (18-25) de comprimento, sobre o anel 2-3 (1-3); setas ventrais $1(d)$ sobre o anel 12-13 (12-15), separadas por 27 (23-27) e por 19 (17-20) microtubérculos,com 37 (3747) de comprimento; setas ventrais 2 (e) sobre o anel 38-39 (38-48), separadas por 17 (15-17) e por 13 (11-15) microtubérculos, com 53 (53-61) de comprimento; setas ventrais $3(f)$ sobre o anel 67 (67-78), separadas por $22(19-27)$ e por $20(20-34)$ microtubérculos, com 38 (38-47) de comprimento. Total de anéis dorsais 83 (80-98), total anéis ventrais 78 (78-92). Seta caudal $\left(h_{2}\right)$ com 57 (57-62) de comprimento; seta acessória $\left(h_{1}\right)$ com $2(2-3)$ de comprimento. Um conjunto de linhas radiais estende-se caudalmente e lateralmente a partir das bases das setas $h_{2}$ e $h_{1}$. 
MACHO - (n=5) Menor do que a fêmea, com 202-225 de comprimento e 46-56 de largura. Gnatossoma com 24 de comprimento. Seta antapical (d) com 11-13 de comprimento; quelíceras com 17-18 de comprimento; estiletes orais com 12-14 de comprimento; curvado ventralmente em um ângulo obtuso. Escudo dorsal como na fêmea, com 48-50 de comprimento e 40-48 de largura; SC sobre tubérculos pouco desenvolvidos, separados entre si por 15-17. Pernas como na fêmea, com todas as setas usuais presentes. Pernas I com 26-30 de comprimento; fêmur com 8-10 de comprimento, $b v$ com 10-11 de comprimento; genu com 5-6 de comprimento, l” com 29-33 de comprimento; tíbia com 6 de comprimento, l' com 6-7 de comprimento; tarso com 6 de comprimento, $f t$ ” com 21-24 de comprimento; $f t^{\prime}$ com 20-22 de comprimento; $u$ ' com 4 de comprimento, solenídio com 6-7 de comprimento, como na fêmea; empódio com 6 de comprimento, 5-6 raios pareados mais um raio apical não pareado. Pernas II com 26-27 de comprimento; fêmur com 9-10 de comprimento, $b v$ com 9-11 de comprimento; genu com 4-5 de comprimento, l” com 11-13 de comprimento; tíbia com 5-6 de comprimento; tarso com 5-6 de comprimento, $f t$ " com 20-23 de comprimento, $f t$ ' com 57 de comprimento, $u^{\prime}$ com 4 de comprimento, solenídio com 7-8 de comprimento, empódio com 6 de comprimento, com 5-6 raios pareados mais um raio apical nãopareado. Coxas: $1 b$ separadas por 14-16, com 10-12 de comprimento; $1 a$ separadas por 9-10, com 25-26 de comprimento; $2 a$ separadas por 25-26, com 26-32 de comprimento. Coxas como na fêmea. Região coxiesternal com 7-9 semi-anéis, microtuberculados. Genitália com 17-18 de largura e 14-17 de comprimento, apresenta: anteriormente uma placa com grânulos esparsos; centralmente com linhas longitudinais delicadas e posteriormente linhas curvas concêntricas, como no desenho; $3 a$ com 11-12 de comprimento. Opistossoma como na fêmea, $c_{2}$ com 17-21 de comprimento, sobre o anel 1; $d$ sobre o anel 9-11, separadas por 19-25 e por 14-19 microtubérculos, com 35-40 de comprimento; $e$ sobre o anel 28-33, separadas por 13-16 e por 11-13 microtubérculos, com 41-47 de comprimento; $f$ sobre o anel 52-57, separadas por 20-23 e por 21-28 microtubérculos, com 32-36 de comprimento. Total de anéis dorsais 68-72, total de anéis ventrais 63-68. Região caudal: $h_{2}$ com 48-57 de comprimento, $h_{1}$ com 2 de comprimento. 
OBSERVAÇÃO - Nas ninfas os anéis opistossomais dorsais e ventrais são microtuberculados.

MATERIAL TIPO - Holótipo fêmea, 13 parátipos fêmea, 15 parátipos machos em quatro preparações microscópicas, 6 de outubro de 2000, de Butia eriospatha (Mart.) Becc. (Arecaceae), Campus of Escola Superior de Agricultura Luiz de Queiroz (ESALQ), Universidade de São Paulo (USP), Piracicaba, São Paulo, Brasil (22 42' 30" S, $47^{\circ} 38^{\prime}$ 00" W), coletados por D. Navia e G.P. de Arruda Filho, na Coleção Acarológica do Setor de Zoologia, Departamento de Entomologia, Fitopatologia e Zoologia Agrícola da ESALQ-USP, Piracicaba, SP, Brasil.

RELAÇÃO COM HOSPEDEIRO - ácaro vagrante coletado de brotos terminais de B. eriospatha, sem causar danos aparentes.

ETIMOLOGIA - a designação específica é proveniente do latim longior (alongado), referente ao opistossoma bastante alongado e atenuado.

\section{Schizacea geonomae Navia \& Flechtmann, 2002}

(Figura 15)

DIAGNOSE - Uma espécie de Schizacea com 7-8 raios em cada um dos ramos do empódio.

OBSERVAÇÃO - Esta é a segunda espécie do gênero Schizacea Keifer, 1977b (Phyllocoptinae, Acaricalini) a ser descrita. S. geonomae Navia \& Flechtmann, 2002 difere da espécie tipo Schizacea gynerii Keifer, 1977b, coletada em Gynerium sagittatum (Gramineae) na Colômbia, por apresentar 7-8 rays nos ramos do empódio (5 


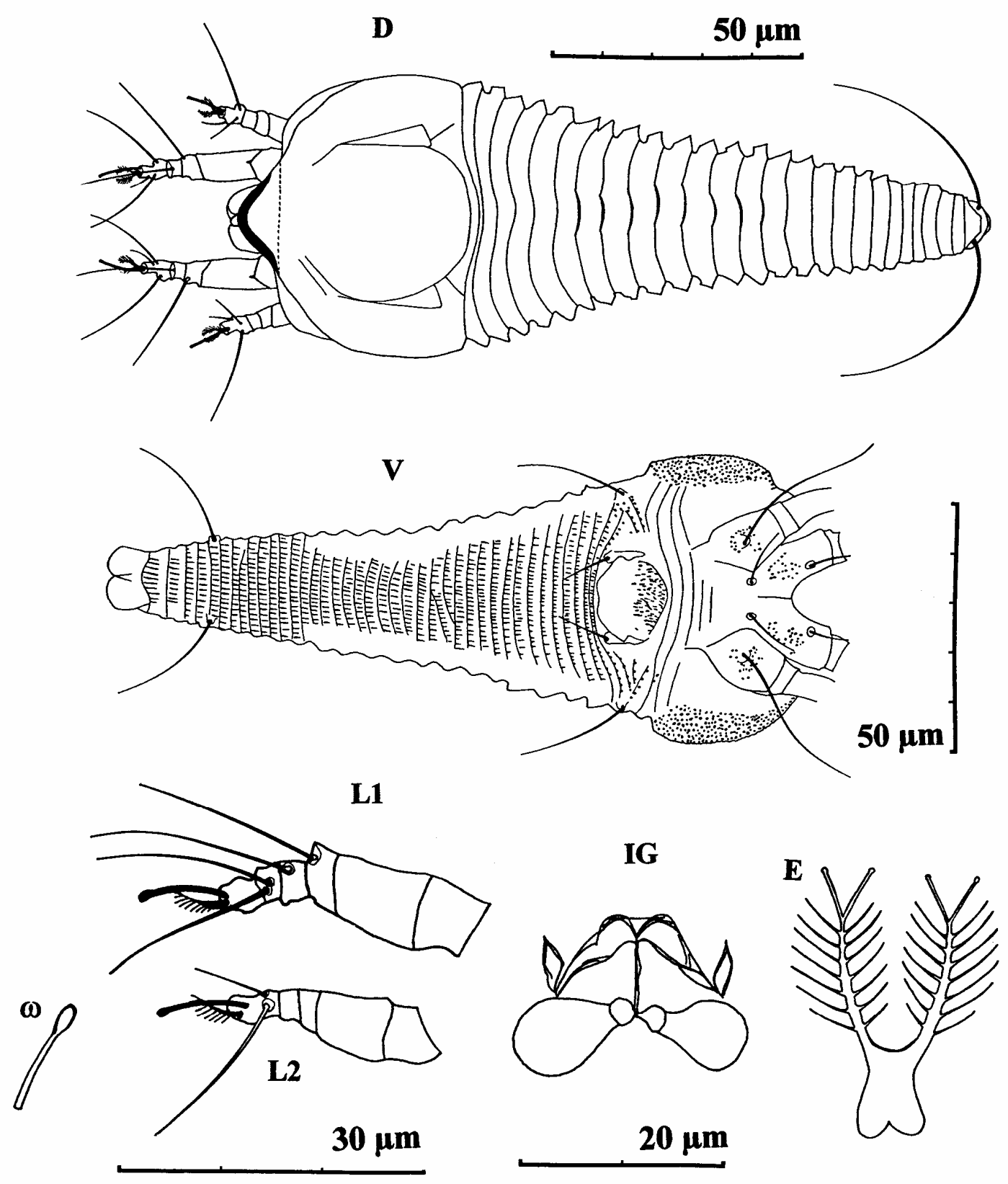

Figura 15 - Schizacea geonomae Navia \& Flechtmann, 2002- D- vista dorsal da fêmea; V- vista ventral da fêmea; IG- genitália interna da fêmea; $\boldsymbol{\omega}$ solenídio $\omega ;$ L1- Pernas I; L2- Pernas II; E- empódio (aumentado) 
raios em S. gynerii); 5 semi-anéis coxigenitais lisos (7 semi-anéis coxigenitais finamente microtuberculados em $S$. gynerii) e algumas setas opistossomais mais curtas: seta lateral (18-19 de comprimento em $S$. geonomae sp. n. e 25 de comprimento em $S$. gynerii) e seta genital (8-10 de comprimento em S. geonomae e 13 de comprimento em S. gynerii).

FÊMEA - (n=7) Comprimento do corpo 136 (123-145), largura 53 (53-57), fusiforme, esbranquiçadas. Gnatossoma curvado ventralmente em um ângulo obtuso, com 18 de comprimento. Seta antapical (d) com 2 de comprimento; quelíceras com 14 de comprimento; estiletes orais com 7 de comprimento. Escudo dorsal com 43 (40-43) de comprimento e 51 (49-56) de largura, contorno anterior semicircular, com lobo frontal arredondado e com a base larga, com 7 (6-8) de comprimento; ornamentação simplificada: centralmente com uma linha subquadrangular em forma de U; das linhas laterais do quadrado originam-se linhas diagonais formando triângulos alongados e póstero-lateralmente originam-se linhas diagonais curtas direcionadas para a margem posterior do escudo. Setas escapulares do escudo dorsal (sc) ausentes. Margens ânterolaterais do escudo dorsal granulada. Pernas: seta femural $(b v)$ ausente nas pernas I e II e seta do genu (l”) ausente nas pernas II. Pernas I com 26 (22-26) de comprimento; fêmur com 11 (10-11) de comprimento; genu com 4 (3-4) de comprimento; seta do genu (l”) com 18 (15-18) de comprimento; tíbia com 4 (3-4) de comprimento; seta da tíbia (l') com 18 (14-18) de comprimento; tarso com 5 (5-6) de comprimento; seta lateral (ft”) com 18 (14-18) de comprimento; seta dorsal (ft') com 15 (11-16) de comprimento; seta unguinal ( $u$ ') com 4 de comprimento; solenídio com 7 (6-8) de comprimento, extremidade levemente expandida; empódio dividido em dois ramos, com 5 de comprimento e com 7-8 raios em cada ramo. Pernas II com 20 (18-21) de comprimento; fêmur com 8 (7-9) de comprimento; genu com 3 de comprimento; tíbia com 3 de comprimento; tarso com 5 (4-5) de comprimento; seta lateral (ft”) com 17 (16-17) de comprimento; seta dorsal ( $f t^{\prime}$ ) com 4 (4-6) de comprimento, seta unguinal ( $u^{\prime}$ ) com 4 de comprimento, solenídio com 7 (5-7) de comprimento, como nas pernas I; empódio como nas pernas I, com 5 (4-5) de comprimento, 7-8 raios em cada ramo. Setas coxais 1 (1b) 
separadas por 11 (11-12), com 8 (7-8) de comprimento; setas coxais 2 (1a) separadas por 5 (4-6), com 17 (12-17) de comprimento; setas coxais 3 (2a) separadas por 20 (18-21), com 28 (22-28) de comprimento. Coxas com grânulos; região lateral densamente granulada. Linha esternal com 5 (4-6). Região coxiesternal com 5 semi-anéis lisos. Epigínio com 18 (16-18) de largura e 13 (11-13) de comprimento, região anterior com grânulos alongados; seta genital (3a) com 10 (8-10) de comprimento. Opistossoma com uma elevação dorso-mediana longitudinal estendendo-se sobre os $2 / 3$ anteriores do opistossoma. Anéis dorsais sem microtubérculos; anéis ventrais com microtubérculos levemente alongados. Seta lateral $\left(c_{2}\right)$ com 18 (18-19) de comprimento, sobre o anel 1-2; setas ventrais $1(d)$ e $2(e)$ ausentes; setas ventrais $3(f)$ sobre o anel 36-37 (34-39), separadas por 14 (14-15) e por 19 (18-21) microtubérculos, com 22 (18-22) de comprimento. Total de anéis dorsais 24 (21-24), total de anéis ventrais 41 (39-43). Seta caudal $\left(h_{2}\right)$ com 33 (33-39) de comprimento; seta acessória $\left(h_{1}\right)$ ausente.

MACHO - não visto.

MATERIAL TIPO - Holótipo fêmea, 5 parátipos fêmeas em 2 preparações microscópicas, 27 de março de 2001, de Geonoma sp. (Arecaceae), "Reserva Estadual de Paraiso", Paraiso, Rio de Janeiro, Brasil (22 29' 23" S, 42 54' 47" W). Dois parátipos fêmeas, em uma preparação microscópica, 29 de fevereiro de 2001, de Geonoma sp. (Arecaceae), Morro Grande, Cotia, São Paulo, Brasil. Coletados por D. Navia e L V. F. da Silva , na Coleção Acarológica do Setor de Zoologia, Departamento de Entomologia, Fitopatologia e Zoologia Agrícola da ESALQ-USP, Piracicaba, SP, Brasil.

RELAÇÃO COM HOSPEDEIRO - este ácaro vagrante foi coletado na superfície inferior de folhas de Geonoma sp., sem causar danos aparentes.

ETIMOLOGIA - A designação específica geonomae refere-se ao gênero da planta hospedeira. 


\section{PHYTOPTIDAE}

\section{Acathrix lobata Navia \& Flechtmann, 2002}

(Figura 16)

\section{DIAGNOSE - Uma Acathrix com lobo frontal.}

OBSERVAÇÃO - Esta é a segunda espécie do gênero Acathrix Keifer, 1962c de Phytoptinae a ser descrita. A. lobata Navia \& Flechtmann, 2002 difere da espécie tipo Acathrix trymatus Keifer, 1962 pela ornamentação do escudo dorsal, com uma área ântero-central lisa (inteiramente ornamentado em A. trymatus); pelo opistossoma menos alongado (57-64 anéis) (90 anéis em A. trymatus); pela presença do lobo frontal (ausente em A. trymatus); pela seta acessória curta (2-3) (13 em A. trymatus); pelo número de raios do empódio (8-9) (11-12 raios em A. trymatus); pelos pequenos tubérculos dorsais (bem-formados em A. trymatus); pela glândula alongada e estreita, próxima à margem posterior do escudo (arredondada em A. trymatus); pelo empódio curto (4-7 de comprimento) (13 de comprimento em A. trymatus) e pelo epigínio anteriormente microtuberculado (totalmente liso em A. trymatus).

FÊMEA - (n=10) Comprimento do corpo 155 (134-167), largura 51 (47-55), vermiforme, esbranquiçada. Gnatossoma curvado ventralmente em um ângulo obtuso, com 18 (18-22) de comprimento. Seta antapical (d) com 6 (5-7) de comprimento; seta basal (ep) com 1 (1-2) de comprimento; quelíceras com 16 (15-18) de comprimento; estiletes orais com 12 (11-14) de comprimento. Escudo dorsal subpentagonal; desenho do escudo consiste em linhas longitudinais curtas, subparalelas, restritas à região posterior, principalmente entre os tubérculos dorsais; linhas centrais mais curtas; externamente à seta escapular do escudo dorsal ( $s c)$, um par de linhas longas curvas, as quais estendem-se da margem anterior à posterior do mesmo; área central lisa; faixas de microtubérculos nas regiões anteriores e látero-posteriores; microtubérculos esparsos nas 


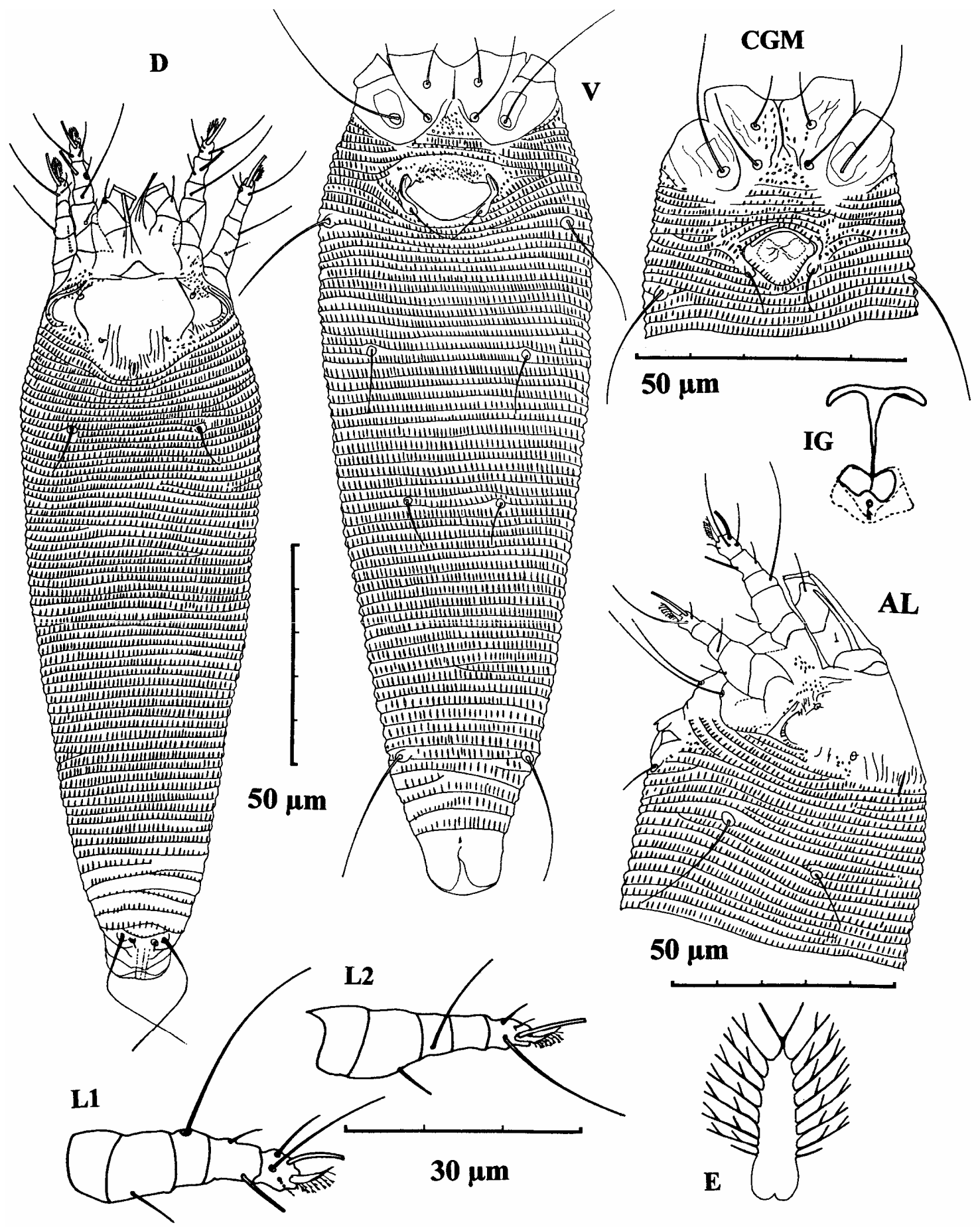

Figura 16 - Acathrix lobata Navia \& Flechtmann, 2002 - D- vista dorsal da fêmea; V- vista ventral da fêmea; AL- região ântero-lateral da fêmea; CGMregião coxigenital do macho; IG- genitália interna da fêmea; L1- Pernas I; L2- Pernas II; E- empódio (aumentado) 
margens anteriores e posteriores. Escudo mais largo que longo, com 29 (22-30) de comprimento e 40 (36-40) de largura, com ângulos posteriores arredondados; glândula mediana alongada e estreita na margem posterior do escudo; lobo frontal subtriangular, margens laterais côncavas, apicalmente arredondadas, com a base flexível, com 4 (4-5) de comprimento. Setas escapulares do escudo dorsal (sc) diminutas, com 1 (1-2) de comprimento, direcionadas para cima, sobre pequenos tubérculos próximos à margem posterior do escudo, separados entre si por 13 (13-16). Setas verticais (ve) diminutas, sobre pequenos tubérculos nos ângulos humerais, com 1 (1-2) de comprimento, separados entre si por 24 (22-31). Pernas com todas as setas usuais presentes. Pernas I com 24 (21-25) de comprimento; fêmur com 6 (6-8) de comprimento; seta femural (bv) com 5 (5-7) de comprimento; genu com 4; seta do genu (l”) com 21 (19-23) de comprimento; tíbia com 5 (4-6) de comprimento; seta da tíbia (l’) com 4 (4-5) de comprimento, solenídio da tíbia com 5 (4-6) de comprimento; tarso com 5 (4-5) de comprimento; seta lateral ( $\left.f t^{\prime \prime}\right)$ com 12 (11-15) de comprimento; seta dorsal ( $\left.f t^{\prime}\right)$ com 6 (6-9) de comprimento; seta unguinal ( $\left.u^{\prime}\right)$ com 3 (2-4) de comprimento; solenídio com 6 (4-7) de comprimento; empódio com 4 (4-5) de comprimento e com 9 (8-9) raios. Pernas II com 21 (18-22) de comprimento; fêmur com 7 (6-7) de comprimento; seta femural (bv) com 4 (4-7) de comprimento; genu com 4 de comprimento; seta do genu (l”) com 10 (10-12) de comprimento; tíbia com 4 de comprimento; tarso com 5 (4-5) de comprimento; seta lateral (ft') com 14 (11-14) de comprimento; seta dorsal (ft') com 3 (2-3) de comprimento, seta unguinal ( $\left.u^{\prime}\right)$ com 2 (2-4) de comprimento, solenídio com 7 (6-8) de comprimento; empódio com 4 (4-6) de comprimento, 8 (8-9) raios. Setas coxais 1 (1b) separadas por 9 (9-11), com 9 (7-9) de comprimento; setas coxais 2 (1a) separadas por 8 (8-10), com 18 (15-19) de comprimento; setas coxais 3 (2a) separadas por 20 (19-22), com 30 (28-33) de comprimento. Coxas com linhas finas, sem grânulos. Linha esternal com 8 (4-8) de comprimento. Região coxiesternal com 5 (4-6) semi-anéis, microtuberculados. Epigínio com 19 (18-21) de largura e 10 (10-11) de comprimento, anteriormente microtuberculados; seta genital (3a) com 7 (6-9) de comprimento. Opistossoma uniformemente arqueado, subigual dorsoventralmente, completamente microtuberculado; microtubérculos alongados, tornam-se pequenos e finos nos 4 últimos 
anéis. Seta dorsal $\left(c_{1}\right)$ com 10 (8-11) de comprimento, sobre o anel 9-10 (8-12), separadas por 27 (27-29) e por 29 (25-39) microtubérculos; seta lateral $\left(c_{2}\right)$ com 21 (1825) de comprimento, sobre o anel 3 (3-6); setas ventrais 1 (d) sobre o anel 14-15 (1316), separadas por 29 (28-32) e por 44 (35-44) microtubérculos, com 12 (11-14) de comprimento; setas ventrais 2 (e) sobre o anel 27-28 (26-30), separadas por 18 (15-20) e por 16 (16-27) microtubérculos, com 9 (8-11) de comprimento; setas ventrais $3(f)$ sobre o anel 49-50 (42-51), separadas por 23 (20-24) e por 20 (19-30) microtubérculos, com 25 (22-28) de comprimento. Total de anéis dorsais 59 (57-64), total de anéis ventrais 53 (50-59). Seta caudal $\left(h_{2}\right)$ com 33 (27-37) de comprimento; seta acessória $\left(h_{1}\right)$ com 3 (23) de comprimento.

MACHO - $(n=5)$ Menor do que a fêmea, com 130-162 de comprimento e 41-56 de largura. Gnatossoma com 18-23 de comprimento. Seta $d$ com 4-6 de comprimento; seta ep com 1-3 de comprimento; quelíceras com 16-17 de comprimento; estiletes orais com 11-13 de comprimento; curvados ventralmente em um ângulo obtuso. Escudo dorsal como na fêmea, com 22-25 de comprimento e 37-47 de largura; lobo frontal com 4-5 de comprimento; sc com 1-2 de comprimento, separadas por 13-18; ve com 1-2 de comprimento, separadas por 23-26. Pernas como na fêmea, com todas as setas usuais presentes. Pernas I com 21-23 de comprimento; fêmur com 6-7 de comprimento, $b v$ com 4-7 de comprimento; genu com 3-4 de comprimento, l" com 15-20 de comprimento; tíbia com 4-5 de comprimento, l' com 4-5 de comprimento, solenídio da tíbia com 6-7 de comprimento; tarso com 4-5 de comprimento, ft" com 11-15 de comprimento, $f t$ ' com 5-8 de comprimento, $u$ ' com 2-3 de comprimento, solenídio com 6 de comprimento; empódio com 5 de comprimento, 8-9 raios. Pernas II com 18-22 de comprimento; fêmur com 5-6 de comprimento, $b v$ com 4-7 de comprimento; genu com 3-4 de comprimento, I" com 10-11 de comprimento; tíbia com 4 de comprimento; tarso com 4-5 de comprimento, $f t$ ”' com 11-14 de comprimento, $f t$ ' com 2-3 de comprimento, $u^{\prime}$ com 2-3 de comprimento, solenídio com 7-8 de comprimento, empódio com 4-5 de comprimento, 7-8 raios. Coxas: $1 b$ separadas por 8-9, com 8-9 de comprimento; $1 a$ separadas por 8-9, com 13-19 de comprimento; 2a separadas por 18-23, com 24-26 de 
comprimento. Coxas como na fêmea. Região coxiesternal com 6-8 semi-anéis, microtuberculados. Genitália com 13 de largura e 9-10 de comprimento; em alguns espécimes a margem posterior apresenta uma linha de microtubérculos, como no desenho; 3a com 6-10 de comprimento. Opistossoma como na fêmea, $c_{1}$ com 8-9 de comprimento, sobre o anel 8-10 annulus, separadas por 24-26 e por 28-35 tubérculos; $c_{2}$ com 16-20 de comprimento, sobre o anel 2-4; $d$ sobre o anel 10-12, separadas por 26-30 e por 33-39 microtubérculos, com 10-11 de comprimento; $e$ sobre o anel 21-25, separadas por 15-17 e por 14-22 microtubérculos, com 7-9 de comprimento; $f$ sobre o anel 39-44, separadas por 22 e por 17-22 microtubérculos, com 20-23 de comprimento. Total de anéis dorsais 54-56, total de anéis ventrais 43-47. Região caudal: $h_{2}$ com 24-35 de comprimento, $h_{1}$ com 2-3 de comprimento.

MATERIAL TIPO - Holótipo fêmea, 10 parátipos fêmeas, 5 parátipos machos, em 3 preparações microscópicas, 11 de novembro de 2000, São Pedro, São Paulo, Brasil ( $\left.22^{\circ} 38^{\prime} 58^{\prime \prime} \mathrm{S}, 47^{\circ} 48^{\prime} 31^{\prime \prime} \mathrm{W}\right)$, de brotos terminais de Geonoma brevispatha Barb. Rodr. Buds. Sete parátipos machos, 11 parátipos fêmeas, em 3 preparações microscópicas, 4 de dezembro de 2000; 3 parátipos fêmeas em uma preparação microscópica, 17 de julho de 2001; 15 parátipos fêmeas, 2 parátipos machos, em 5 preparações microscópicas, 7 de julho de 2000, "Fazenda Canchim", Embrapa, São Carlos, São Paulo, Brasil (21 ${ }^{\circ}$ 54' 50" $\mathrm{S}, 47^{\circ} 49^{\prime}$ 21" W), de Geonoma sp. (Arecaceae). Oito parátipos fêmeas, 3 parátipos machos, em 3 preparações microscópicas, 11 de outubro de 2000, Cananéia, São Paulo, Brasil ( $\left.24^{\circ} 53^{\prime} 45^{\prime \prime} \mathrm{S}, 47^{\circ} 50^{\prime} 17^{\prime \prime} \mathrm{W}\right)$, de Geonoma schottiana Mart. Coletados por D. Navia e L. V. F. da Silva, na Coleção Acarológica do Setor de Zoologia, Departamento de Entomologia, Fitopatologia e Zoologia Agrícola da ESALQ-USP, Piracicaba, SP, Brasil.

RELAÇÃO COM HOSPEDEIRO - ácaro vagrante coletado de brotos terminais de G. schottiana e G. brevispatha e de folhas de Geonoma sp., sem causar danos aparentes. 
ETIMOLOGIA -A designação específica lobata é derivada do latim lobus, (lobo) mais o sufixo do latim ata, atus, a (tendo a condição de), referindo-se à presença de um lobo frontal no escudo.

\section{Palmiphytoptus Navia \& Flechtmann, 2002}

(Figura 17)

DIAGNOSE - Este novo gênero apresenta corpo alongado, vermiforme. Escudo dorsal pentagonal; lobo frontal presente; seta ântero-lateral presente (vertical externa). Setas escapulares (sc) e tubérculos ausentes. Pernas com setas da tíbia ausentes. Anéis opistossomais subiguais dorsoventralmente; seta lateral $\left(c_{2}\right)$ e todas as setas ventrais presentes.

ESPÉCIE TIPO: Palmiphytoptus oculatus Navia \& Flechtmann, 2002

ETIMOLOGIA - O nome genérico é composto de palm, o nome vulgar das plantas hospedeiras "palmeiras", e phytoptus da família Phytoptidae.

OBSERVAÇÃO - (Sierraphytoptinae, Mackiellini) A espécie tipo, P. oculatus assemelha-se a Acathrix trymatus Keifer, 1962c, de Phytoptinae, em relação ao corpo vermiforme e aos anéis opistossomais subiguais dorsoventralmente, mas difere por apresentar o lobo frontal no escudo dorsal, pela ausência de: setas escapulares (sc), tubérculos dorsais, de uma "glândula" na margem posterior central do escudo, da seta opistossomal dorsal $\left(c_{1}\right)$ e da seta da tíbia (l').

Palmiphytoptus foi tentativamente incluido na tribo Mackiellini Keifer, 1946 de Sierraphytoptinae Keifer 1944, devido à ausência da seta opistossomal dorsal $c_{1}$. Os anéis opistossomais subiguais dorsoventralmente posiscionam o novo gênero em uma situação intermediária entre Phytoptinae e Sierraphytoptinae. 


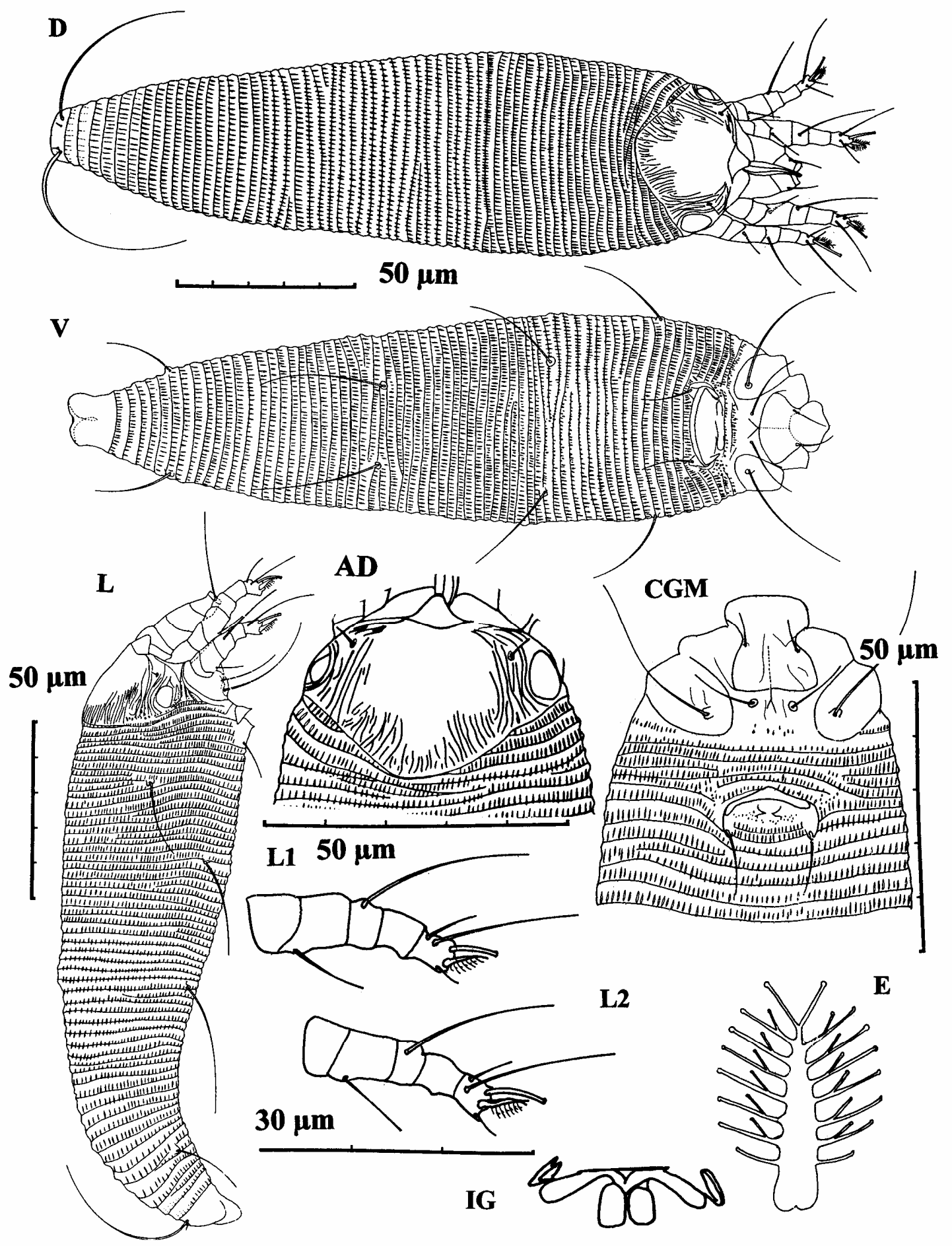

Figura 17 - Palmiphytoptus oculatus Navia \& Flechtmann, 2002 - D- vista dorsal da fêmea; V-vista ventral da fêmea; L- vista lateral da fêmea; AD- região ântero-dorsal da fềmea; CGM- região coxigenital do macho; IGgenitália interna da fêmea; L1- Pernas I; L2- Pernas II; E- empódio (aumentado) 


\section{Palmiphytoptus oculatus Navia \& Flechtmann, 2002}

(Figura 17)

FÊMEA - (n=10) Comprimento do corpo 172 (145-180), largura 48 (44-59), vermiforme, esbranquiçada. Gnatossoma curvado ventralmente em um ângulo obtuso, com 18 (18-22) de comprimento. Seta antapical (d) com 7 (6-8) de comprimento; quelíceras com 17 (16-18) de comprimento. Escudo dorsal: área central lisa, sem ornamentação; áreas anteriores, laterais e posteriores com linhas sinuosas e interrompidas em algumas regiões; um par de proeminentes estruturas em forma de olhos nos ângulos látero-posteriores do escudo; com 27 (25-28) de comprimento e 37 (35-45) de largura, pentagonal, com ângulos anteriores e posteriores arredondados; lobo frontal com a base larga e flexível, subtriangular, com as margens laterais côncavas, arredondado apicalmente; com 5 (5-6) de comprimento. Seta escapular (sc) do escudo dorsal e tubérculos ausentes; seta vertical externa (ve) em ângulos humerais, com 3 (2-4) de comprimento, separadas entre si por 23 (20-23), direcionadas para cima, sobre tubérculos diminutos; em alguns espécimens (3 de um total de 40 espécimens) uma seta ve estava ausente. Pernas com a seta da tíbia (l') ausente. Pernas I com 23 (22-26) de comprimento; fêmur com 7 (7-8) de comprimento; seta femural (bv) com 7 (6-9) de comprimento; genu com 4 (4-4) de comprimento; seta do genu (l”) com 19 (18-24) de comprimento; tíbia com 4 (4-6) de comprimento; tarso com 5 (4-6) de comprimento, seta lateral (ft”) com 14 (12-18) de comprimento, seta dorsal ( $\left.f t^{\prime}\right)$ com 7 (5-7) de comprimento, seta unguinal ( $u$ ') com 3 (2-3) de comprimento; solenídio com 5 (5-7) de comprimento, levemente expandido no ápice e achatado; empódio com 6 (4-6) de comprimento, 8 raios. Pernas II com 22 (21-22) de comprimento; fềmur com 8 (7-8) de comprimento; seta femural (bv) com 7 (6-7) de comprimento; genu com 4 (4-5) de comprimento; seta do genu (l”) com 13 (12-19) de comprimento; tíbia com 4 (4-5) de comprimento; tarso com 4 (4-6) de comprimento; seta lateral ( $f t$ ”) com 16 (14-18) de comprimento; seta dorsal ( $\left.f t^{\prime}\right)$ com 5 (4-7) de comprimento; seta unguinal ( $u$ ') com 2 de comprimento, solenídio com 6 (6-7) de comprimento, como nas pernas I ; empódio com 6 (4-6) de comprimento e com 7 (7-8) raios. Setas coxais 1 (1b) separadas por 8 (7-9), 
com 8 (6-8) de comprimento; setas coxais 2 (1a) separadas por 7 (6-7), com 15 (11-15) de comprimento; setas coxais 3 (2a) separadas por 20 (19-22), com 30 (26-33) de comprimento. Coxas lisas. Linha esternal tênue. Cobrindo parcialmente a área das coxas fundidas, uma estrutura trapezoidal em forma de babador, delimitada lateralmente por um par de linhas que se estendem na área externa às bases das setas coxais 1 (1b) divergentemente, para trás e posteriormente por uma linha transversal curvada em posição anterior às bases das setas coxais 2(1a). Região coxiesternal com 2 (2-4) semianéis, microtuberculados. Epigínio com 19 (18-21) de largura e 5 (5-8) de comprimento, sem ornamentação; seta genital (3a) com 12 (9-12) de comprimento. Opistossoma com uma leve depressão longitudinal dorso-mediana larga na região anterior; anéis completamente microtuberculados; microtubérculos alongados, próximos às bordas posteriores dos anéis, muito mais curtos na área médio-ventral à frente das bases da seta opistossomal ventral $1(d)$. Seta lateral $\left(c_{2}\right)$ em posição látero-dorsal e em alguns indivíduos em posição um pouco mais dorsal, em linha longitudinal com a seta ve, com 20 (18-21) de comprimento, sobre o anel 5 (4-6); setas ventrais $1(d)$ sobre o anel 16-17 (13-17), separadas por $30(30-38)$ e por 40 (39-48) microtubérculos, com 25 (22-26) de comprimento; setas ventrais 2 (e) sobre o anel 34-35 (30-36), separadas por 18 (17-19) e por 17 (17-24) microtubérculos, com 30 (24-30) de comprimento; setas ventrais $3(f)$ sobre o anel 53-54 (45-56), separadas por 25 (19-25) e por 25 (21-25) microtubérculos, com 18 (16-22) de comprimento. Total de anéis dorsais 57 (46-59), total de anéis ventrais 58 (50-61). Seta caudal $\left(h_{2}\right)$ com 40 (36-40) de comprimento; seta acessória $\left(h_{1}\right)$ com 1 de comprimento.

MACHO - $(n=5)$ Menor do que a fêmea, com 141-151 de comprimento e 42-48 de largura. Gnatossoma curvado ventralmente em um ângulo obtuso, com 19-26 de comprimento. Seta $d$ com 3-4 de comprimento; quelíceras com 17 de comprimento. Escudo dorsal como na fêmea, com 26-29 de comprimento e 35-40 de largura; ve com 2 de comprimento, separadas por 20-23. Pernas com seta da tíbia (l') ausente. Pernas I com 20-23 de comprimento; fêmur com 7 de comprimento, bv com 6-7 de comprimento; genu com 4 de comprimento, l” com 14-22 de comprimento; tíbia com 4 de 
comprimento; tarso com 4-6 de comprimento, ft" com 12-16 de comprimento, ft' com 58 de comprimento, $u$ ' com 2-3 de comprimento, solenídio com 6-7 de comprimento, como na fêmea; empódio com 5 de comprimento, 7-8 raios. Pernas II com 19-20 de comprimento; fêmur com 6-7 de comprimento, $b v$ com 6-7) de comprimento; genu com 3-4 de comprimento, l" com 13-18 de comprimento; tíbia com 4 de comprimento; tarso com 4-5 de comprimento, $f t$ " com 12-18 de comprimento, $f t$ ' com 4-5 de comprimento, u' com 2 de comprimento, solenídio com 6 de comprimento, empódio com 4-5 de comprimento, 7-8 raios. Coxas: $1 b$ separadas por 7-8, com 6 de comprimento; $1 a$ separadas por 6-7, com 12-14 de comprimento; $2 a$ separadas por 18-20, com 23-26 de comprimento. Coxas como na fêmea. Região coxiesternal com 4-5 semi-anéis, microtuberculados. Genitália com 12-15 de largura e 5-6 de comprimento, com alguns grânulos, dois anéis microtuberculados na margem posterior, como no desenho; $3 a$ com 10-11 de comprimento. Opistossoma, $c_{2}$ com 12-18 de comprimento, sobre o anel 4-6; $d$ sobre o anel 13-15, separados por 25-33 e por 29-41 microtubérculos, com 17-21 de comprimento; $e$ sobre o anel 25-32, separadas por 15-16 e por 16-20 microtubérculos, com 21-26 de comprimento; $f$ sobre o anel 41-54, separadas por 18-23 e por 24-29 microtubérculos, com 15-21 de comprimento. Total de anéis dorsais 47-54, total de anéis ventrais 46-59. Caudal região: $h_{2}$ com 22-34 de comprimento, $h_{1}$ com 1-2 de comprimento.

MATERIAL TIPO - Holótipo fêmea, 15 parátipos fêmeas, 2 parátipos machos, em 5 preparações microscópicas, 18 de abril de 2000, Pariquera-Açu, São Paulo, Brasil, ( $24^{\circ} 36^{\prime} 41^{\prime \prime} \mathrm{S}, 47^{\circ} 49^{\prime} 32^{\prime \prime} \mathrm{W}$ ); 4 parátipos fêmeas, 1 parátipo macho, em 3 preparações microscópicas, 11 de outubro de 2000, Cananéia, São Paulo, Brasil, (24 53' 45" S, $47^{\circ}$ $50^{\prime} 17^{\prime \prime} \mathrm{W}$ ), de brotos terminais de $B$. setosa. Cinco parátipos machos, 4 parátipos fêmeas, em 3 preparações microscópicas, 11 de outubro de 2000; 1 parátipo fêmea, 19 de Março de 2000, Cananéia, São Paulo, Brasil; 2 parátipos fêmeas, 3 parátipos machos em 2 preparações microscópicas, 14 de outubro de 2000, Pariquera-Açu, São Paulo, Brasil, de brotos terminais de Astrocaryum aculeatissimum (Schott) Burret.. Dois parátipos fêmeas, em 1 preparação microscópica, 27 de março de 2001, "Reserva 
Estadual de Paraiso", Rio de Janeiro, Brasil, (22 29' 23" S, 42 $52^{\circ}$ ' 47" W), de folhas de A. aculeatissimum. Coletados por D. Navia e L. V. F. da Silva, na Coleção Acarológica do Setor de Zoologia, Departamento de Entomologia, Fitopatologia e Zoologia Agrícola da ESALQ-USP, Piracicaba, SP, Brasil.

RELAÇÃO COM HOSPEDEIRO - ácaro vagrante em brotos terminais de $B$. setosa e em brotos terminais e folhas de A. aculeatissimum, sem causar danos aparentes.

ETIMOLOGIA - A designação específica, do latim oculatus (que apresenta olhos), referindo-se ao par de estruturas proeminentes em forma de olhos no escudo dorsal.

\section{Propilus pellitus Navia \& Flechtmann, 2002}

(Figuras 18-19)

DIAGNOSE - Um Propilus com setas verticais externas (ve) visíveis dorsalmente, lobo frontal subtriangular e apicalmente acuminado, projeções laterais dos anéis opistossomais moderadamente desenvolvidos e epigínio coberto basalmente por uma membrana delicada, estriada transversalmente. Opistossoma com uma elevação dorso-mediana longitudinal.

OBSERVAÇÃO - Esta é a quarta espécie do gênero Propilus Keifer, 1975a (Sierraphytoptinae, Mackiellini) a ser descrita. Esta nova espécie difere de Propilus syagris Gondim Jr., Flechtmann \& Moraes 2000 por apresentar as setas verticais externas (ve) visíveis dorsalmente; de Propilus spinosus Keifer, 1975a pela ausência de linhas longitudinais no lobo frontal subtriangular; de Propilus gentyi Keifer, 1975a pela presença de projeções laterais nos anéis opistossomais; de $P$. syagris e de $P$. spinosus por apresentar projeções opistossomais laterais apenas moderadamente desenvolvidas, as 


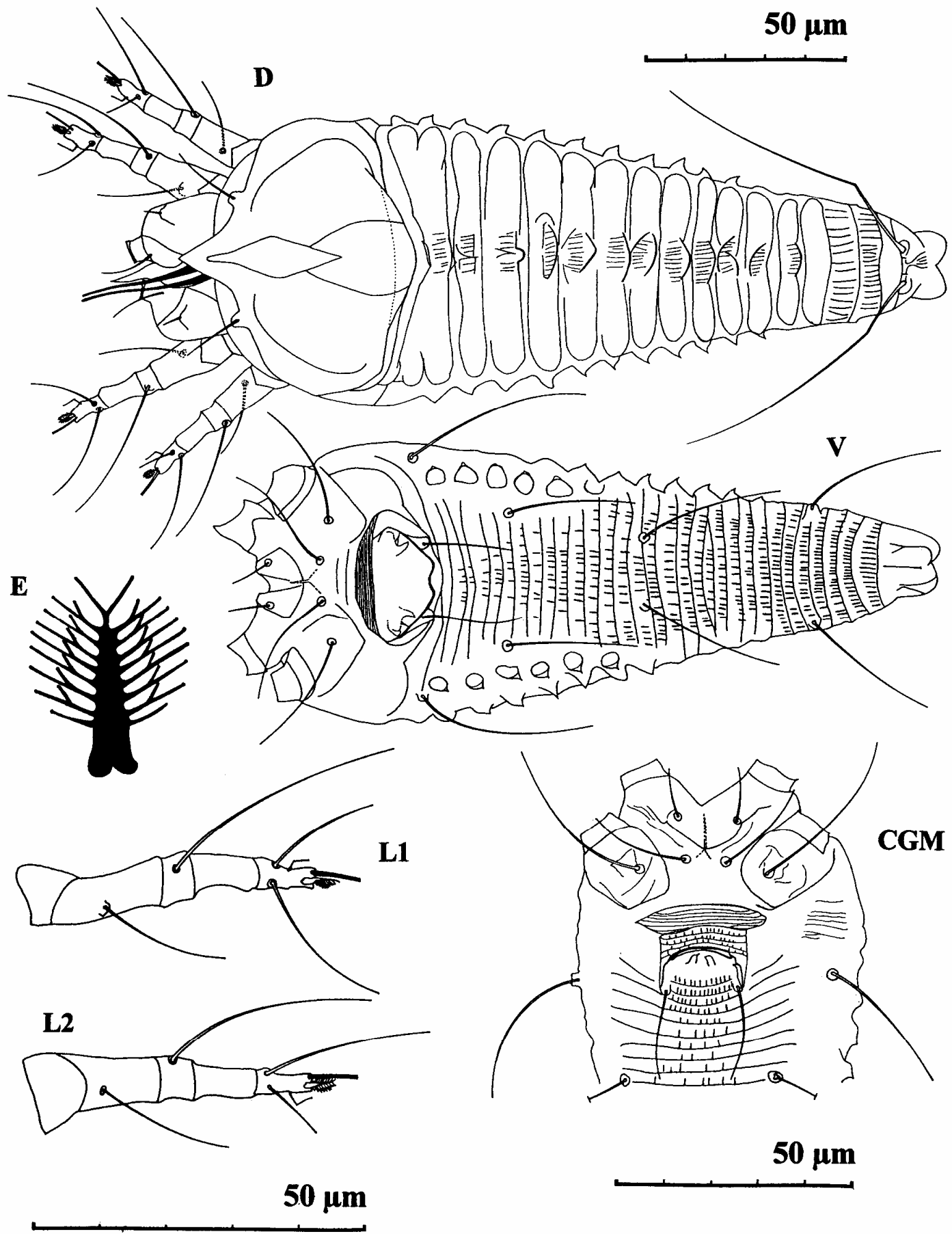

Figura 18 - Propilus pellitus Navia \& Flechtmann, 2002- D- vista dorsal da fêmea; V- vista ventral da fêmea; CGM- região coxigenital do macho; L1Pernas I; L2- Pernas II; E- empódio (aumentado) 


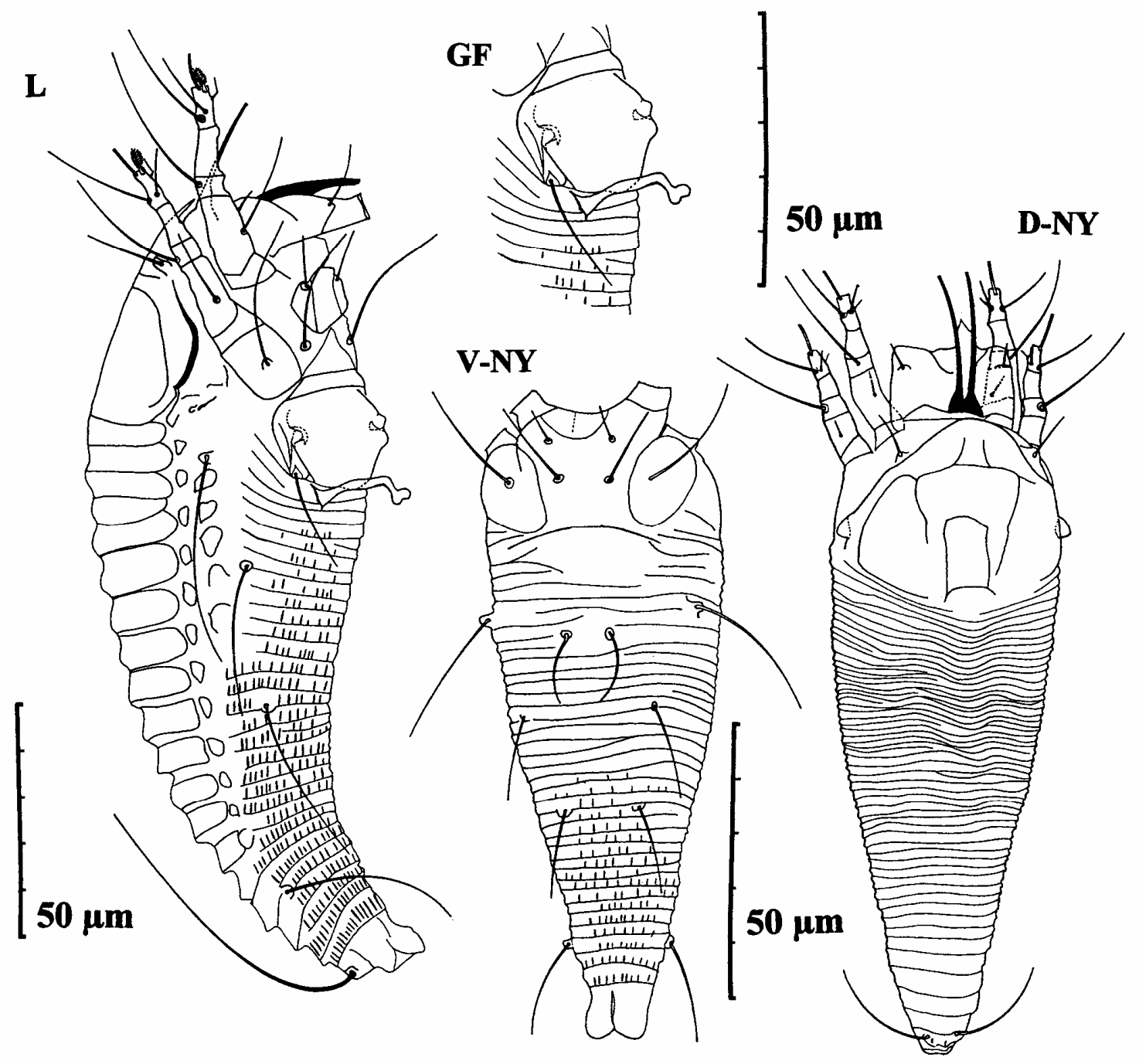

Figura 19 - Propilus pellitus Navia \& Flechtmann, 2002- L- vista lateral da fêmea; GF- genitália da fêmea com espermatóforo aderente; V-NYvista ventral da ninfa; D-NY - vista dorsal da ninfa 
quais não tem forma de espinhos. Propilus pellitus Navia \& Flechtmann, 2002 também difere das demais espécies por apresentar uma fina membrana transversal, finamente estriada, na região anterior do epigínio. Coxas I são completamente fundidas apresentando uma linha conspícua em forma de "V". A região coxigenital do macho apresenta, em sua porção anterior, duas áreas bem diferenciadas: 1) 4-5 anéis microtuberculados anteriores à frente da margem anterior da genitália, aparentemente separada do tegumento lateral liso, sem anéis; 2) anterior a estes anéis, uma fina membrana estriada (similar à membrana anterior à genitália da fêmea). Seta unguinal (u') angulada como no gênero Catachela (Keifer, 1969) de Anthocoptini, Phyllocoptinae.

FÊMEA - (n=10) Comprimento do corpo 154 (136-161), largura 59 (49-60), fusiforme, amarelada. Gnatossoma curvado ventralmente em um ângulo obtuso, com 22 (21-29) de comprimento. Seta antapical (d) com 10 (10-12) de comprimento; quelíceras com 22 (22-28) de comprimento; estiletes orais com 18 (17-19) de comprimento. Escudo dorsal com 48 (44-48) de comprimento e 54 (46-57) de largura, subcircular, com ângulos posteriores arredondados; lobo frontal anterior amplamente triangular, apicalmente acuminado, com a base larga, com 9 (9-10) de comprimento. Seta escapular (sc) do escudo dorsal ausente; setas verticais externas (ve) sobre tubérculos desenvolvidos, com 16 (14-16) de comprimento, separados por 24 (19-24). Desenho do escudo consistindo em um losângulo alongado ântero-centralmente; linhas curvas látero-posteriores direcionadas para a margem posterior e linhas curvas acompanhando a margem do escudo ântero-lateralmente. Pernas sem seta da tíbia (l') I, todas as outras setas usuais presentes. Pernas I com 38 (33-38) de comprimento; fêmur com 12 (12-14) de comprimento; seta femural (bv) com 19 (17-19) de comprimento; genu com 4 de comprimento; seta do genu (l”) com 32 (29-34) de comprimento; tíbia com 8 (7-9) de comprimento; tarso com 8 (7-9) de comprimento; seta lateral ( $f$ ”) com 23 (19-23) de comprimento; seta dorsal ( $\left.f t^{\prime}\right)$ com 10 (10-13) de comprimento; seta unguinal ( $\left.u^{\prime}\right)$ curvada em ângulo reto, o segmento proximal com 2 (2-3) de comprimento e o distal com 3 (3-4) de comprimento; solenídio com 6 (5-6) de comprimento, empódio 
com 5 (4-5) de comprimento, 9 (8-9) raios. Pernas II com 33 (32-35) de comprimento; fêmur com 12 (11-13) de comprimento; seta femural (bv) com 16 (16-22) de comprimento; genu com 4 de comprimento; seta do genu (l”) com 26 (24-27) de comprimento; tíbia com 8 (7-8) de comprimento; tarso com 7 (7-8) de comprimento; seta lateral (ft”) com 19 (19-20) de comprimento; seta dorsal ( $\left.f t^{\prime}\right)$ com 5 (5-8) de comprimento, seta unguinal ( $\left.u^{\prime}\right)$ como nas pernas I, segmento proximal com 2 de comprimento e distal com 3 (3-4) de comprimento, solenídio com 6 (6-7) de comprimento; empódio com 4 (4-5) de comprimento, 9 (8-9) raios. Setas coxais 1 (1b) separadas por 9 (9-10), com 10 (8-11) de comprimento; setas coxais 2 (1a) separadas por 9 (6-10), com 25 (19-26) de comprimento; setas coxais 3 (2a) separadas por 26 (22-27), com 30 (30-37) de comprimento. Coxas sem grânulos. Linha esternal com 6 (6-10) de comprimento. Região coxiesternal com 1 (0-2) semi-anel, liso. Epigínio liso com 28 (25-29) de largura e 18 (16-18) de comprimento, basalmente coberto por uma fina membrana estriada transversalmente; seta genital (3a) com 18 (18-19) de comprimento. Opistossoma com uma elevação dorso-mediana longitudinal, a qual apresenta, em seu ápice, alguns microtubérculos alongados, também presentes em toda a extensão dos dois últimos anéis dorsais; anéis ventrais esparsamente microtuberculados, microtubérculos são mais densos e mais alongados nos dois últimos anéis ventrais. Seta lateral $\left(c_{2}\right)$ com 35 (35-40) de comprimento, sobre o anel 2-3 (2-4); setas ventrais $1(d)$ sobre o anel 6-7 (6-10), separadas por 28 (25-30) e por 8 (6-10) microtubérculos, com 26 (26-33) de comprimento; setas ventrais 2 (e) sobre o anel 16-17 (16-19), separadas por 13 (13-15) e por 5 (5-9) microtubérculos, com 32 (30-34) de comprimento; setas ventrais $3(f)$ sobre o anel 28-29 (28-31), separadas por 24 (18-24) e por 18 (15-23) microtubérculos, com 30 (30-40) de comprimento. Total de anéis dorsais 17 (16-17), total de anéis ventrais 32 (32-35). Seta caudal $\left(h_{2}\right)$ com 56 (52-59) de comprimento; seta acessória $\left(h_{1}\right)$ ausente.

OBSERVAÇÃO - Uma fêmea, em posição lateral na preparação microscópica, com um espermatóforo aderente próximo à genitália, nos dois primeiros anéis ventrais (Figura 19, L). 
MACHO - $(\mathrm{n}=5)$ Menor do que a fêmea, com 127-147 de comprimento e 48-59 de largura. Gnatossoma com 24-26 de comprimento. Seta $d$ com 9-11 de comprimento; quelíceras com 20-23 de comprimento; estiletes orais com 15-18 de comprimento; curvado ventralmente em um ângulo obtuso. Escudo dorsal como na fêmea, com 42-44 de comprimento e 43-54 de largura; lobo frontal com 9 de comprimento; setas ve com 11-13 de comprimento, separadas entre si por 19-21. Pernas como na fêmea. Pernas I com 31-36 de comprimento; fêmur com 11-13 de comprimento, $b v$ com 16-17 de comprimento; genu com 4 de comprimento, l” com 24-29 de comprimento; tíbia com 79 de comprimento; tarso com 7 de comprimento, $f t$ ” com 15-18 de comprimento, $f t$ ' com 9-10 de comprimento, $u$ ' como na fêmea, segmento proximal com 2 de comprimento e o distal com 3 de comprimento, solenídio com 5-6 de comprimento; empódio com 4 de comprimento, 8-9 raios. Pernas II com 30-33 de comprimento; fêmur com 11-12 de comprimento, bv com 16-18 de comprimento; genu com 4 de comprimento, l” com 2225 de comprimento; tíbia com 7-8 de comprimento; tarso com 6-7 de comprimento, ft” com 15-19 de comprimento, ft' com 5-7 de comprimento, $u$ ' segmento proximal com 2 de comprimento e distal com 3-4 de comprimento, solenídio com 6-7 de comprimento, empódio 4 de comprimento e com 8-9 raios. Coxas: $1 b$ separadas por 10-11, com 9-11 de comprimento; $1 a$ separadas por 6-7, com 18-23 de comprimento; $2 a$ separadas por 20-22, com 30-33 de comprimento. Linha esternal com 6-7 de comprimento. Região coxiesternal com duas áreas bem diferenciadas: 1) 4-5 anéis microtuberculados á frente da margem anterior da genitália, aparentemente separados do tegumento lateral liso, sem anéis; 2) anterior a estes anéis, uma fina membrana estriada (similar à membrana anterior à genitália da fêmea). Genitália lisa, com 14-16 de largura e 11 de comprimento, com dois anéis microtuberculados na região posterior entre os tubérculos das setas genitais $3 a$, com 17-18 de comprimento. Opistossoma como na fêmea, $c_{2}$ com 31-39 de comprimento, sobre o anel 3-4; $d$ sobre o anel 8-10, separadas por 25-26 e por 7-13 microtubérculos, com 26-30 de comprimento; $e$ sobre o anel 17-19, separadas por 12-15 e por 6-9 microtubérculos, com 30-33 de comprimento; $f$ sobre o anel 29-32, separadas por 20-23 e por 19-22 microtubérculos, com 30-40 de comprimento. Total de 
anéis dorsais 17, total de anéis ventrais 33-35. Região caudal: $h_{2}$ com 44-53 de comprimento, $h_{1}$ ausente.

NINFA - $(\mathrm{n}=1)$ Comprimento do corpo 97, largura 35, fusiforme, amarelada. Gnatossoma curvado ventralmente em um ângulo obtuso, com 18 de comprimento. Seta $d$ com 4 de comprimento; ep com 4 de comprimento; quelíceras com 22 de comprimento; estiletes orais com 13 de comprimento. Escudo dorsal com 31 de comprimento e 33 de largura, subcircular, com ângulos posteriores arredondados; lobo frontal ausente. Setas escapulares $(s c)$ do escudo dorsal ausentes; ve sobre tubérculos desenvolvidos, com 7 de comprimento, separadas por 19. Ornamentação distinta dos adultos, como no desenho. Pernas com l' das pernas I ausentes, todas as outras setas usuais presentes. Pernas I com 20 de comprimento; fêmur com 6 de comprimento; $b v$ com 3 de comprimento; genu com 3 de comprimento; l” com 16 de comprimento; tíbia com 6 de comprimento; tarso com 6 de comprimento; ft" com 10 de comprimento; $f t$ ' com 5 de comprimento; $u$ ' com 2 de comprimento; solenídio com 5 de comprimento, empódio com 4 de comprimento, 6-7 raios. Pernas II com 18 de comprimento; fêmur com 5 de comprimento; $b v$ com 3 de comprimento; genu com 3 de comprimento; l" com 18 de comprimento; tíbia com 4 de comprimento; tarso com 6 de comprimento; $f t$ " com 11 de comprimento; $f t^{\prime}$ com 3 de comprimento, $u^{\prime}$ com 2 de comprimento, solenídio com 4 de comprimento; empódio com 4 de comprimento, 7 raios. Setas $1 b$ separadas por 9, com 9 de comprimento; $1 a$ separadas por 7, com 14 de comprimento; $2 a$ separadas por 20, com 19 de comprimento. Coxas sem grânulos. Linha esternal com 3 de comprimento. Região coxiesternal como no desenho, lisa. Seta $3 a$ com 11 de comprimento. Opistossoma sem diferenciação dorso-ventral (adultos com diferenciação dorso-ventral); um número maior de anéis dorsais que ventrais; elevação dorso-mediana longitudinal. Anéis dorsais sem microtubérculos; anéis ventrais esparsamente microtuberculados na metade posterior do opistossoma. Seta $c_{2} \operatorname{com} 23$ de comprimento, sobre o anel 2-3; $d$ sobre o anel 9-10, separadas por 19, com 14 de comprimento; $e$ sobre o anel 17-18, separadas por 10 e por 4 microtubérculos, com 14 de comprimento; $f$ sobre o anel 28-29, separadas por 14 e por 17 microtubérculos, com 16 de comprimento. Total 
de anéis dorsais 51 , total de anéis ventrais 31 . Seta $h_{2}$ com 22 de comprimento; $h_{1}$ diminuta, com 1 de comprimento.

MATERIAL TIPO - Holótipo fêmea, 19 parátipos fêmeas, 44 parátipos machos, 1 ninfa parátipo, em 13 preparações microscópicas, 29 de fevereiro de 2001, de $L$. hoehnei, Morro Grande, Cotia, São Paulo, Brasil, coletados por D. Navia e L. V. F. da Silva, na Coleção Acarológica do Setor de Zoologia, Departamento de Entomologia, Fitopatologia e Zoologia Agrícola da ESALQ-USP, Piracicaba, SP, Brasil.

RELAÇÃO COM HOSPEDEIRO - ácaro vagrante coletado na superfície onferior de folhas de L. hoehnei, sem causar danos aparentes.

ETIMOLOGIA -A designação específica pellitus é derivada do latim pellis (pele, película, coberto com pele), referindo-se à membrana que cobre a porção basal do epigínio.

\subsection{Conclusões}

* Três novos gêneros e 17 novas espécies de Eriophyoidea associados às palmeiras ocorrem em localidades do Brasil, França e México. 


\section{5 ÁCAROS ERIOPHYOIDEA (PROSTIGMATA) ASSOCIADOS A PALMEIRAS (ARECACEAE) NO MUNDO: HOSPEDEIROS, DISTRIBUIÇÃO GEOGRÁFICA E CHAVE PARA IDENTIFICAÇÃO}

\section{Resumo}

Visando facilitar estudos futuros sobre os ácaros Eriophyoidea associados a palmeiras, foram reunidas neste capítulo as informações, publicadas e novas (adquiridas durante o desenvolvimento deste projeto) sobre as espécies desta superfamília associadas a este grupo de plantas, incluindo sua distribuição geográfica, partes das plantas infestadas, sintomas e danos ocasionados. Também foi elaborada uma chave dicotômica para auxiliar na separação destes ácaros. Até o momento, foram relatadas 57 espécies, pertencentes a 30 gêneros de Eriophyoidea associadas a 50 espécies de 24 gêneros de palmeiras. Dentre estas espécies de ácaros, 4 pertencem a Diptilomiopidae, 42 a Eriophyidae e 9 a Phytoptideae. Na Europa são conhecidas 4 espécies de Eriophyoidea em palmeiras; na África, 6; na Ásia e Ilhas do Pacífico, 14; e nas Américas, 35 espécies.

\section{ERIOPHYOIDEA MITES (PROSTIGMATA) ASSOCIATED WITH PALM TREES (ARECACEAE) IN THE WORLD: DISTRIBUTION, HOSTS AND IDENTIFICATION KEY}

\section{Summary}

To facilitate future studies on Eriophyoidea mites associated with palm trees, this chapter summarizes information on mites of that superfamily reported in the literature 
and new (acquired during development of this project) associated with plants of that group, including data on distribution, plant species, attacked plant parts, symptoms and damage. Up to now, 57 species belonging to 30 genera associated with 50 palm tree species of 24 genera. Four mite species belong to the Diptilomiopidae, 42 to the Eriophyidae and 9 to the Phytoptidae. Four Eriophyoidea species are known from palm trees in Europe, 6 in Africa, 14 in Asia, Pacific Islands and Australia, and 35 in the Americas. A dicotomous key is also provided to help in the separation of the species reported on those plants.

\subsection{Introdução}

As palmeiras são plantas monocotiledôneas extremamente diversas, compondo a grande família Arecaceae, e encontram-se amplamente distribuídas por todo o mundo, especialmente em áreas tropicais e subtropicais. Entre as palmeiras, está um grande número de espécies de elevada importância econômica, como por exemplo, no Brasil, o coqueiro (Cocos nucifera L.), os palmitos açaí (Euterpe oleracea Mart.), juçara (Euterpe edulis Mart.) e pupunha (Bactris gasipaes Kunth); a carnaúba (Copernicia prunifera (Miller) H.E. Moore); o babaçu (Attalea speciosa Mart. Ex Spreng.); e o dendezeiro (Elaeis guineensis N. J. Jacquin) (Lorenzi, 1996). As áreas de cultivo de algumas destas espécies vem se expandindo consideravelmente.

Os ácaros da superfamília Eriophyoidea são estritamente fitófagos e podem atingir o status de praga em agroecossitemas, constituindo o segundo grupo de ácaros de maior importância agrícola, após os tetraniquídeos (Lindquist et al., 1996a). Ácaros fitófagos associados a hospedeiros cujas culturas vem se expandindo representam pragas potenciais. O conhecimento dos ácaros fitófagos e de suas interações com os inimigos naturais em seu habitat natural pode possibilitar um melhor manejo dos agroecossistemas.

Muito pouco se conhece sobre os ácaros Eriophyoidea associados a palmeiras no Brasil e no mundo. Entre as 3500 espécies que constituem o grupo das palmeiras 
(Lorenzi, 1996), foram relatados ácaros eriofiídeos associados a apenas 50 destas espécies (Amrine Jr. \& de Lillo, 2003).

Considerando a importância econômica atual e potencial das palmeiras e dos ácaros Eriophyoidea como pragas, considera-se relevante ampliar o conhecimento sobre os ácaros desta família associados àquelas plantas.

As informações sobre os Eriophyoidea associados às palmeiras no mundo encontram-se dispersas. As descrições de algumas espécies são bastante antigas, não completas, ou foram publicadas em periódicos de difícil acesso para a maior parte da comunidade científica. Diversas espécies novas foram descritas e relatos de novos hospedeiros foram realizados nos últimos 20 anos, especialmente na região Neotropical (Flechtmann, 1994,1998; Gondim Jr. et al., 2000; Navia \& Flechtmann, 2002, 2003ab). A compilação das informações e a elaboração de chaves para auxiliar na identificação das espécies já descritas facilitará sobremaneira a realização de estudos futuros.

Este trabalho teve como objetivo reunir as informações disponíveis sobre os ácaros Eriophyoidea associados a palmeiras, incluindo sua distribuição geográfica, hospedeiros, sintomas e danos ocasionados, assim como elaborar uma chave para auxiliar na separação das espécies/gêneros relatados na literatura sobre estas plantas.

\subsection{Material e Métodos}

A compilação das informações sobre os Eriophyoidea associados a palmeiras foi realizada utilizando-se a base de dados do "Catalog of Eriophyoid Mites” desenvolvida por Amrine Jr. \& de Lillo (2003), na West Virginia University, além das descrições das espécies e demais publicações sobre distribuição geográfica, hospedeiros, danos etc. Foram ainda acrescentadas as informações obtidas durante as avaliações conduzidas durante este projeto de tese.

A chave dicotômica para auxiliar na separação dos gêneros de Eriophyoidea associados a palmeiras foi elaborada tendo como base Amrine Jr. et al. (2003), e na 
separação das espécies, as descrições originais das mesmas (ou, em alguns casos, de espécies próximas a estas).

\subsection{Resultados e Discussão}

Até o momento, foram relatadas em todo o mundo 57 espécies pertencentes a 30 gêneros de Eriophyoidea associadas a 50 espécies de 24 gêneros de palmeiras. Dentre estes ácaros, 4 pertencem a Diptilomiopidae, 42 a Eriophyidae, e 9 a Phytoptidae. Os locais de ocorrência, hospedeiros e sintomas ocasionados por cada uma das espécies são indicadas a seguir.

\section{DIPTILOMIOPIDAE}

\section{Diptilomiopinae}

\section{Davisella palmea (Flechtmann, 1998)}

Rhynacus palmeus Flechtmann, 1998 (Amrine, Stasny \& Flechtmann, 2003)

Espécie descrita de Syagrus romanzoffiana (Cham.) Glassm., Parque Nacional do Itatiaia, Rio de Janeiro, Brasil. Vagueadores ${ }^{1}$, na superfície superior de folíolos. Os ácaros foram coletados juntamente com populações numerosas de uma espécie de Retracrus Keifer, 1965. As folhas infestadas apresentavam áreas manchadas com aparência de oleosidade, onde ambas espécies estavam presentes (Flechtmann, 1998). Esta espécie também foi encontrada em folhas de Euterpe edulis Mart. no Estado de São Paulo, Brasil (Gondim Jr., 2000). 


\section{Dialox stellatus Keifer, 1962}

Espécie tipo do gênero, descrita de Cocos nucifera L., de Guinobatan, Albay, Filipinas (Keifer, 1962a). Os ácaros ocorrem comumente em coqueiros jovens, em frutos bastante jovens. Também são vagueadores em folhas mais velhas, não tendo sido até agora relatado em folhas jovens (Briones \& Sill, 1963). Até o momento é a única espécie descrita no gênero Dialox (Amrine Jr. \& de Lillo, 2003).

Estes ácaros formam massas de cera esbranquiçada em forma de estrelas sobre o corpo, podendo ser vistos a olho nu e confundidos com pequenas cochonilhas (Keifer, 1962c; Briones \& Sill, 1963).

Foi investigada a ação da espécie como vetora da virose “cadang-cadang” nas Filipinas, com resultados negativos. Ocorrem em pequenas populações, sem causar danos aparentes (Briones \& Sill, 1963; Moore \& Howard, 1996).

\section{Diptacus borinquensis Cromroy, 1958}

Espécie vagueadora, descrita de Roystonea sp., de Corozal, Porto Rico (Cromroy, 1958). O único relato da espécie refere-se a sua descrição original (Amrine Jr. \& de Lillo, 2003).

\section{Neodialox palmyrae Mohanasundaram, 1983}

Espécie tipo do gênero, descrita de Borassus flabellifer L., de Vriddhachalam, Tamil Nadu, India. Estes ácaros são vagueadores e foram coletados de folíolos (Mohanasundaram, 1983). Até o momento é a única espécie conhecida do gênero. O único relato da espécie refere-se a sua descrição original (Amrine Jr. \& de Lillo, 2003).

\footnotetext{
${ }^{1}$ que vivem em ambientes expostos, não são associados a galhas ou eríneas.
} 


\section{ERIOPHYIDAE}

\section{Cecidophyinae, Colomerini}

\section{Colomerus novahebridensis Keifer, 1977}

Espécie descrita de C. nucifera, de Saraoutou, Santo, Ilhas de New Hebrides, Vanuatu. Os ácaros foram primeiramente encontrados sob brácteas de frutos maduros (Keifer, 1977a). Apresenta ampla distribuição no sudeste da Ásia e Oceania (Hall et al., 1980; Kang, 1981). Alguns danos têm sido observados nas Filipinas, em alguns híbridos desenvolvidos no oeste da África (Moore \& Howard, 1996). Aparentemente não afeta a produção de coco (Kang, 1981). Em Nova Guiné e em Nova Hebrides foram coletados espécimes infectados por Hirsutella thompsonii Fisher (Hall et al., 1980).

\section{Eriophyinae, Eriophyini}

\section{Aceria biornata Navia \& Flechtmann, 2002}

Esta espécie foi descrita de Acrocomia aculeata (Jacq.) Lodd., Estação Ecológica de Ibicatu, Piracicaba, São Paulo, Brasil. Os ácaros foram encontrados em broto terminal, aparentemente sem causar danos (Navia \& Flechtmann, 2002).

\section{Aceria guerreronis Keifer, 1965}

Os espécimes tipo foram coletados de frutos de C. nucifera em Guerrero, México (Keifer, 1965). Apresenta ampla distribuição geográfica nas Américas e África (Moore \& Howard, 1996). Recentemente sua presença foi relatada também no sudeste asiático, na India e em Sri Lanka (Sathiamma et al., 1998; Fernando et al., 2000). No Brasil, além de infestar frutos, a espécie também foi relatada causando a morte do broto terminal de 
plantas jovens de C. nucifera (Aquino \& Arruda, 1967). Além do coqueiro, outros três hospedeiros foram relatados para A. guerreronis: Lytocaryum weddellianum (H. Wendl.) Tol., no Estado de São Paulo, Brasil (Flechtmann, 1994); S. romanzoffiana, na Califórnia, EUA (Ansaloni \& Perring, 2002); e B. flabellifer, na India e Sri Lanka (Ramaraju \& Rabindra, 1991; Moraes \& Fernando ${ }^{2}$ ). Este eriofiídeo representa uma praga-chave para a cultura do coco na maioria das áreas de produção das localidades onde está presente (Moore \& Howard, 1996).

\section{Aceria gymnoscuta Navia \& Flechtmann, 2002}

Espécie descrita de Syagrus flexuosa (Mart.) Becc., da Reserva Estadual da Serra do Japi, Jundiaí, São Paulo, Brasil. Os ácaros foram encontrados na superfície inferior dos folíolos. Espécimes desta espécie vagueadora também foram coletados sob as brácteas de frutos de Syagrus cocoides Mart., Fazenda Santa Elisa, Instituto Agronômico de Campinas, Campinas, São Paulo, Brasil, aparentemente sem causar danos (Navia \& Flechtmann, 2002).

\section{Aceria translinea Navia \& Flechtmann, 2002}

Espécie descrita de brotos terminais de Attalea dubia (Mart.) Burret., PariqueraAçu, São Paulo, Brasil. Também foram encontrados ácaros desta espécie em brotos terminais de S. romanzoffiana, na Estação Ecológica de Ibicatu, Piracicaba, São Paulo, Brasil. Em ambos hospedeiros, os ácaros foram considerados vagueadores e, aparentemente, não causavam danos aos hospedeiros (Navia \& Flechtmann, 2002).

Nacerimina gutierrezi Keifer, 1979

\footnotetext{
2 MORAES, G.J.de. (Escola Superior de Agricultura Luiz de Queiroz (ESALQ), Universidade de São
} Paulo) \& FERNANDO, L.C.P (Coconut Research Institute, Lunuwila, Sri Lanka) (Em elaboração). 
Espécie tipo do gênero, descrita de folíolos de C. nucifera, em Pago Pago, Tuituila, Samoa. Os espécimes foram coletados entre os tricomas das nervuras principais (Keifer, 1979). O único relato da espécie consiste em sua descrição original (Amrine Jr. \& de Lillo, 2003).

Proartacris longior Navia \& Flechtmann, 2002

Espécie descrita de Butia eriospatha (Mart.) Becc., Piracicaba, São Paulo, Brasil. Estes ácaros vagueadores foram coletados em brotos terminais, aparentemente sem causar danos (Navia \& Flechtmann, 2002).

\section{Phyllocoptinae, Acaricalini}

\section{Knorella geonomae Gondim Jr., Flechtmann \& Moraes, 2000}

Espécie descrita de Geonoma schottiana Mart., Cananéia, São Paulo, Brasil. Os ácaros foram coletados na superfície inferior das folhas (Gondim Jr., Flechtmann \& Moraes, 2000). Neste trabalho, espécimes de K. geonomae foram coletados também de brotos terminais de G. schottiana, em Pariquera-Açu e Cananéia, São Paulo, Brasil.

Nasuchus pindobates Navia \& Flechtmann, 2002

Espécie tipo do gênero, descrita de Geonoma gamiovora Barb. Rodr., Estação Ecológica de Jataí, Luiz Antônio, São Paulo, Brasil. Estes ácaros vagueadores foram coletados na superfície inferior dos folíolos, sem causar danos aparentes (Navia \& Flechtmann, 2002). 


\section{Schizacea geonomae Navia \& Flechtmann, 2002}

Espécie descrita de Geonoma sp., Reserva Estadual de Paraiso, Rio de Janeiro, Brasil. Representantes desta espécie também foram coletados sobre Geonoma sp. na Reserva Estadual de Morro Grande, Cotia, São Paulo, Brasil. Estes ácaros vagueadores foram coletados na superfície inferior dos folíolos sem causar danos aparentes (Navia \& Flechtmann, 2002).

\section{Tumescoptes dicrus Meyer, 1992}

Espécie descrita de Phoenix reclinata Jacq., de Donkerhoek, Rustenberg, Transvaal, África do Sul. Ácaros coletados em dobras de folhas jovens (Meyer, 1992). O único relato de ocorrência da espécie corresponde à sua descrição original (Amrine Jr. \& de Lillo, 2003).

\section{Tumescoptes phoenixi Meyer, 1992}

Espécie descrita de Phoenix canariensis Hort., de Pretoria, Trannsvaal, África do Sul. Os ácaros foram encontrados nas dobras de folhas jovens, principalmente na região apical das folhas (Meyer, 1992). O único relato de ocorrência da espécie corresponde à sua descrição original (Amrine Jr. \& de Lillo, 2003).

\section{Tumescoptes trachycarpi Keifer, 1939}

Espécie tipo do gênero, descrita de Trachycarpus fortunei (W. J. Hooker) H. Wendl., interceptada em San Francisco, Califórnia, EUA (Keifer, 1939a). Ocorre na China (Kuang, 1991), de onde a espécie hospedeira é originária (Lorenzi, 1996). Os ácaros são encontrados nas dobras centrais das folhas. Aparentemente não causam danos (Keifer, 1939a). Esta espécie também foi relatada em Abu-Ghraib, Bagdad, Iraque, infestando Phoenix dactylifera L. (Mohamed \& El-Haidari, 1968). 


\section{Phyllocoptinae, Anthocoptini}

Notostrix acuminata Navia \& Flechtmann, 2003

Os espécimes tipo foram coletados de brotos terminais e da superfície inferior de folíolos de A. aculeata, Ibicatu, Piracicaba, São Paulo, Brasil. Os autores também coletaram espécimes de folíolos de Syagrus oleracea (Mart.) Becc. Estes ácaros vagueadores são vistos como listras de cera branca nas regiões laterais das nervuras principais dos folíolos (Navia \& Flechtmann, 2003b).

\section{Notostrix attenuata Keifer, 1963}

Espécie tipo do gênero. Foi coletada de folíolos de folhas maduras de C. nucifera em Guinobatan, Albay, Filipinas (Keifer, 1963). O segundo registro da espécie é de Kayangulam, Kerala, India, também de folíolos de C. nucifera (Mohanasundaram, 1984). No Brasil foi relatada pela primeira vez em Sergipe, do mesmo hospedeiro (Flechtmann \& Santana, 1997). Posteriormente, foi coletada de duas outras palmeiras, $A$. aculeata e S. romanzoffiana, em São Paulo, Brasil (Gondim Jr., 2000).

\section{Notostrix butiae Gondim Jr., Flechtmann \& Moraes, 2000}

Esta espécie foi descrita da superfície inferior de folíolos de B. eriospatha, Piracicaba, São Paulo, Brasil (Gondim Jr., Flechtmann \& Moraes, 2000). No presente estudo $^{3} N$. butiae foi coletada sobre cinco novos hospedeiros: em folíolos de Attalea geraensis Barb. Rodr., Pirassununga e Luiz Antonio, São Paulo, Brasil; folíolos e brotos terminais de Butia archeri (Glass.) Glass., Pirassununga, São Paulo, Brasil; folíolos de Butia capitata (Mart.) Becc., Campinas, São Paulo, Brasil; folíolos de Syagrus microphylla Burret, Luiz Antonio e Pirassununga, São Paulo, Brasil; folíolos de Syagrus quinquefaria Becc., Piracicaba, São Paulo, Brasil. Os espécimes coletados de B. archeri, 
B. capitata e S. microphylla apresentaram algumas medidas ligeiramente diferentes dos espécimes tipos, basicamente com setas mais longas e epigínio mais curto e largo.

Estes ácaros são normalmente encontrados ao longo das nervuras principais na superfície inferior de folíolos velhos. Raramente se deslocam na lâmina das folhas; vivem e se reproduzem ao longo das nervuras principais dos folíolos (Briones, 1963). O envolvimento da espécie na transmissão da doença “cadang-cadang” foi investigado nas Filipinas, com resultados negativos.

\section{Notostrix exigua Flechtmann, 1998}

Espécimes tipo foram coletados de folíolos de E. edulis, no Parque Nacional do Itatiaia, Rio de Janeiro, Brasil. Os ácaros foram coletados na superfície superior de folíolos, onde eram facilmente visualizados como listras de cera branca. Considerados vagueadores (Flechtmann, 1998). Ácaros desta espécie também foram coletados de folíolos de E. edulis no Estado de São Paulo e de Euterpe sp. em Pernambuco, Brasil (Gondim Jr., 2000). No presente estudo, N. exigua foi também coletada em folíolos e brotos terminais de Bactris setosa Mart., em São Paulo, Brasil.

\section{Notostrix fissipes Navia \& Flechtmann , 2003}

Esta espécie foi descrita de A. dubia, Pariquera-Açu, São Paulo, Brasil. Os ácaros foram coletados na superfície inferior de folíolos, ao longo das nervuras principais, onde foram vistos como listras de cera branca (Navia \& Flechtmann, 2003b).

\section{Notostrix flabelliferae Mohanasundaram, 1982}

Espécie conhecida somente de sua descrição original, de B. flabellifer, em Vriddhachalam, Tamil Nadu, India (Amrine Jr. \& de Lillo, 2003). Os ácaros foram

\footnotetext{
${ }^{3}$ levantamentos realizados durante o desenvolvimento deste projeto de tese, detalhado no Capítulo 3.
} 
coletados ao longo das nervuras de folhas jovens ainda não abertas (Mohanasundaram, 1982).

\section{Notostrix jamaicae Keifer, 1970}

Espécie também descrita de folhas de C. nucifera, de Woodstock, Jamaica (Keifer, 1970). Assim como N. attenuata, foi encontrada da superfície inferior de folíolos. Na Costa Rica, a espécie também foi coletada em folíolos de coqueiros (Schliesske, 1988). Dois outros hospedeiros foram relatados para a espécie no Brasil: S. romanzoffiana, no Distrito Federal e Rio de Janeiro; e Attalea sp., no Distrito Federal (Santana \& Flechtmann, 1998).

\section{Notostrix longiseta Navia \& Flechtmann , 2003}

Os espécimes tipo foram coletados da superfície inferior de folíolos de $B$. archeri, Pirassununga, São Paulo, Brasil. Ácaros vistos como listras de cera branca ao longo da nervura principal (Navia \& Flechtmann, 2003b).

\section{Notostrix miniseta Navia \& Flechtmann , 2003}

Espécie descrita de folíolos de Bactris vulgaris Barb. Rodr., Pariquera-Açu, São Paulo, Brasil. Parátipos adicionais foram coletados de folíolos de B. setosa, na mesma localidade. Os ácaros foram coletados na superfície inferior dos folíolos, ao longo da nervura principal, vistos como listras esbranquiçadas de cera (Navia \& Flechtmann, 2003b).

Notostrix nasutiformes Gondim Jr., Flechtmann \& Moraes, 2000

Espécie descrita da superfície inferior de folíolos de C. nucifera, em Igarassu, Pernambuco, Brasil. Os autores também encontraram $N$. nasutiformes em folíolos de 
Bactris ferruginea Burret., Igarassu, Pernambuco, Brasil; A. dubia, B. gasipaes e B. setosa, em Pariquera-Açu, e Attalea phalerata Mart. ex Spreng., Piracicaba, São Paulo, Brasil (Gondim Jr., Flechtmann \& Moraes, 2000). No presente estudo, espécimes de $N$. nasutiformes foram encontrados pela primeira vez no México, onde foram coletados na superfície inferior de folíolos de C. nucifera em Chetumal, Quintana Roo.

Notostrix trifida Navia \& Flechtmann, 2003

Espécimes tipo foram coletados da superfície inferior de folíolos de Lytocaryum hoehnei (Burret.) Toledo, Reserva Estadual de Morro Grande, Cotia, São Paulo, Brasil. Assim como algumas outras espécies de Notostrix, os ácaros são vistos como listras brancas de cera ao longo das nervuras principais (Navia \& Flechtmann, 2003b).

Notostrix vazquezae Navia \& Flechtmann, 2003

Espécie descrita de folhas de Sabal sp., Chetumal, Quintana Roo, México. Os ácaros são vagueadores e foram coletados na superfície superior de folhas, na região das nervuras e nas dobras das folhas (Navia \& Flechtmann, 2003b).

\section{Phyllocoptinae, Calacarini}

\section{Calacarus palmae Mohanasundaram, 1994}

Os espécimes tipo foram coletados de Collinia sp., Tamil Nadu, India (Mohanasundaram, 1994). Espécie conhecida unicamente de sua descrição original (Amrine Jr. \& de Lillo, 2003). 


\section{Phyllocoptinae, Phyllocoptini}

\section{Acritonotus denmarki Keifer 1962}

Espécie tipo do gênero, descrita de folíolos de Roystonea elata (Bartr.) F. Harper, em Fort Lauderdalle, Florida, EUA. Estes ácaros foram relatados causando bronzeamento de folhas de plantas jovens em viveiros (Keifer, 1962a). Também na Flórida, EUA, este ácaro foi coletado em folíolos de C. nucifera (Moore \& Howard, 1996).

\section{Adenoptus chamaeropsi Mitrofanov, Sekerskaya \& Sharonov 1983}

Espécie tipo descrita de Chamaerops humilis L., Nikitskij Botanical Gardens, Yalta, Crimea, Ucrânia (Mitrofanov, Sekerskaya \& Sharonov 1983). Espécie conhecida apenas de sua descrição original (Amrine Jr. \& de Lillo, 2003).

\section{Adenoptus migeoni Navia \& Flechtmann, 2003}

Esta foi a segunda espécie do gênero a ser descrita. Assim como A. chamaeropsi, foi coletada de $C$. humilis. Os espécimes foram coletados na superfície inferior dos folíolos, em Montpellier, Languedoc-Roussillon, França (Navia \& Flechtmann, 2003a).

\section{Amrineus cocofolius Flechtmann, 1994}

Espécie tipo do gênero, descrita de folíolos de C. nucifera, em Jales, São Paulo, Brasil. Estes ácaros foram considerados vagueadores, causando cloroses que podiam evoluir para necroses (Flechtmann, 1994). A espécie foi redescrita a partir de um maior número de indivíduos por Flechtmann (1997). A espécie também foi constatada em C. nucifera em Sergipe, Pernambuco, Bahia e Ceará (Santana \& Flechtmann, 1998; Flechtmann, 1997). No presente estudo, além de C. nucifera, A. cocofolius foi 
encontrado infestando folíolos de B. archeri, em Campinas; folíolos de B. eriospatha, em Piracicaba; folíolos de A. geraensis, em São Carlos; e frutos de S. romanzoffiana, em Piracicaba, São Paulo, Brasil. Ferreira et al. (2001) relataram pela primeira vez a infestação de frutos de coco por $A$. cocofolius causando o sintoma denominado "mancha anelar do fruto do coqueiro". No presente estudo, colônias de A. cocofolius também foram encontradas em frutos de coco em alguns estados brasileiros e em Celestún, Yucatan, México (Capítulo 9).

\section{Amrineus coconuciferae (Keifer, 1962)}

Acamina coconuciferae Keifer, 1962 (Flechtmann, 1994).

Espécie descrita de C. nucifera, em Coral Gables, Florida, EUA. Os ácaros são vagueadores sobre os folíolos (Keifer, 1962b). A espécie é conhecida apenas de sua descrição original (Amrine Jr. \& de Lillo, 2003).

\section{Calepitrimerus livistonae Wei \& Feng, 2002}

Espécie vagueadora descrita de Livistona chinensis (Jacq.) R. Barb., Nanning, Guangxi Zhuang, China (Wei \& Feng, 2002). A espécie é conhecida apenas de sua descrição original (Amrine Jr. \& de Lillo, 2003).

\section{Epitrimerus calami Keifer, 1969}

Espécie descrita de folíolos de Calamus australis Mart., das proximidades de Nambour, Queensland, Austrália. Os ácaros foram relatados causando manchas amareloamarronzadas de 0,5 a 1cm de diâmetro, na superfície inferior dos folíolos. Tufos de cera esbranquiçada produzidos pelos ácaros tendem a cobrir os mesmos e as áreas amarronzadas das folhas (Keifer, 1969). 


\section{Epitrimerus elaeis Boczek \& Natcheff, 1989}

Espécie descrita de folíolos de E. guineensis, de Lame, Costa do Marfim. Estes ácaros vagueadores foram coletados na superfície inferior de folíolos, ao longo das nervuras principais (Boczek \& Natcheff, 1989). Espécimes também foram coletados em C. nucifera na Costa do Marfim (Amrine \& de Lillo, 2003).

\section{Epitrimerus englerus Huang, 2001}

Espécie descrita de Arenga englera Beccari, de Hualien, Walapi, Taiwan. Os ácaros foram coletados na superfície inferior dos folíolos, aparentemente sem causar danos (Huang, 2001). A espécie é conhecida apenas de sua descrição original (Amrine Jr. \& de Lillo, 2003).

\section{Epitrimerus steveni Mitrofanov, Sekerskaya \& Sharonov 1983}

Espécie tipo descrita de C. humilis, de Nikitskij Botanical Gardens, Yalta, Crimea, Ucrânia (Mitrofanov, Sekerskaya \& Sharonov 1983). Espécie conhecida apenas de sua descrição original (Amrine Jr. \& de Lillo, 2003).

\section{Gilarovella caniculata Mitrofanov, Sekerskaya \& Sharonov 1983}

Espécie tipo do gênero, descrita de C. humilis, de Nikitskij Botanical Gardens, Yalta, Crimea, Ucrânia (Mitrofanov, Sekerskaya \& Sharonov 1983). Até o momento constitui a única espécie de Gilarovella. Espécie conhecida apenas de sua descrição original (Amrine Jr. \& de Lillo, 2003). 
Espécie tipo do gênero descrita de B. flabellifer, de Massanjore, Santhaparganas, Bihar, India. Os ácaros foram coletados sobre os folíolos ao longo das nervuras principais (Das \& Chakrabarti, 1985). Até o momento, é a única espécie conhecida no gênero. Espécie conhecida unicamente de sua descrição original (Amrine Jr. \& de Lillo, 2003).

\section{Phyllocoptes mariaui Boczek \& Natcheff, 1989}

Espécie descrita de E. guineensis, de Lame, Costa do Marfim. Os ácaros são vagueadores e foram encontrados na superfície inferior dos folíolos, abaixo de uma fina camada de cera que se ocorre naturalmente sobre as nervuras principais de E. guineensis, causando manchas amareladas (Boczek \& Natcheff, 1989). Espécie relatada apenas de sua descrição original (Amrine Jr. \& de Lillo, 2003).

\section{Phyllocoptinae, Tegonotini}

\section{Glabrisceles euterpis Navia \& Flechtmann, 2002}

Espécie tipo do gênero, descrita de E. edulis Mart., Pariquera-Açu, São Paulo, Brasil. Estes ácaros vagueadores foram coletados em brotos terminais, sem causar danos aparentes (Navia \& Flechtmann, 2002). Espécie relatada apenas de sua descrição original (Amrine Jr. \& de Lillo, 2003).

\section{Scolocenus spiniferus Keifer 1962}

Espécie tipo do gênero, descrita de folíolos de C. nucifera, Guinobatan, Albay, Filipinas. Os ácaros foram encontrados nas folhagens e considerados vagueadores (Keifer, 1962a). Foram realizados estudos para averiguar o papel desta espécie na transmissão do agente causador de “cadang-cadang”, com resultados negativos (Briones 
\& Sill, 1963). Até o momento constitui a única espécie do gênero (Amrine Jr. \& de Lillo, 2003).

\section{Tegonotus gutierrezi Boczek \& Natcheff, 1989}

Espécie descrita de E. guineensis, de Lame, Costa do Marfim. Os ácaros foram encontrados na superfície inferior dos folíolos, ao longo da nervura principal (Boczek \& Natcheff, 1989). Espécie relatada apenas de sua descrição original (Amrine Jr. \& de Lillo, 2003).

\section{PHYTOPTIDAE}

\section{Phytoptinae}

\section{Acathrix lobata Navia \& Flechtmann, 2002}

Espécie coletada de brotos terminais de Geonoma brevispatha Barb. Rodr., em São Pedro e de G. schottiana, Cananéia, São Paulo, Brasil; e de folíolos de Geonoma sp., Fazenda Canchim, Embrapa, São Carlos, São Paulo, Brasil. Estes ácaros, vagueadores, aparentemente não causam danos aos hospedeiros (Navia \& Flechtmann, 2002).

\section{Acathrix trymatus Keifer, 1962}

Espécie tipo do gênero, coletada em folíolos jovens de $C$. nucifera, Guinobatan, Albay, Filipinas (Keifer, 1962c). Colônias numerosas foram encontradas em brotos terminais de plantas com “cadang-cadang” nas Filipinas. Seu potencial de transmissão do agente causal da doença foi investigado, com resultados negativos (Briones \& Sill, 
1963). A presença do ácaro também foi relatada na Flórida, EUA (Welbourn ${ }^{4}$ citado por Amrine \& de Lillo, 2003).

\section{Sierraphytoptinae, Mackiellini}

\section{Mackiella borasis Mohanasundaram, 1981}

Espécie descrita de B. flabellifer, de Vriddhachalam, Tamil Nadu, India. Os ácaros foram coletados nas dobras de folhas jovens ainda não abertas (Mohanasundaram, 1981). Espécie relatada apenas de sua descrição original (Amrine Jr. \& de Lillo, 2003).

\section{Mackiella phoenicis Keifer, 1939}

Espécie tipo do gênero, descrita de $P$. dactylifera, de Indio, Riverside, California, EUA. Os ácaros foram coletados em dobras no centro das folhas de brotos terminais, aparentemente sem causar danos ao hospedeiro (Keifer, 1939b). Sua presença também foi relatada em Abu-Ghraib, Bagdad, Iraque, infestando o mesmo hospedeiro (Mohamed \& El-Haidari, 1968).

\section{Palmiphytoptus oculatus Navia \& Flechtmann, 2002}

Espécie tipo do gênero, coletada de brotos terminais de $B$. setosa e de folhas de Astrocaryum aculeatissimum (Schott) Burret., Cananéia, São Paulo, Brasil, sem causar danos aparentes aos hospedeiros. Estes ácaros são vagueadores (Navia \& Flechtmann, 2002). Espécie relatada apenas de sua descrição original (Amrine Jr. \& de Lillo, 2003).

4 WELBOURN, C. Acathrix trymatus Keifer in Florida (Acari: Eriophyidae (Phytoptidae)). Gainesville: Florida Department of Agricultural Service, Division of Plant Industry $1997.2 p$. (Entomology Circular, 383). 


\section{Propilus gentyi Keifer, 1975}

Espécie tipo do gênero, descrita de Aiphanes sp., de San Alberto, Bucaramanga, Santander, Colômbia (Keifer, 1975a). Os ácaros foram relatados causando bronzeamento na superfície inferior das folhas. Esta espécie também foi encontrada no Brasil, em folíolos de A. aculeatissimum, em Cananéia (Gordim Jr., 2000); e de B. vulgaris, Pariquera-Açu e Cananéia, São Paulo (Capítulo 3).

Propilus pellitus Navia \& Flechtmann, 2002

Espécie descrita de L. hoehnei, Reserva Estadual de Morro Grande, Cotia, São Paulo, Brasil. Estes ácaros, vagueadores, foram coletados na superfície inferior dos folíolos, aparentemente sem causar danos aos hospedeiros (Navia \& Flechtmann, 2002).

\section{Propilus spinosus Keifer, 1975}

Espécie descrita de Aiphanes sp., de San Alberto, Bucaramanga, Colômbia (Keifer, 1975a). Os ácaros foram relatados causando bronzeamento na superfície inferior das folhas. Esta espécie também foi encontrada no Brasil, em folíolos de $S$. romanzoffiana, de Pariquera-Açu, São Paulo; e de B. setosa, Pariquera-Açu e Jundiaí, São Paulo, Brasil, (Gordim Jr., 2000; Capítulo 3).

\section{Propilus syagris Gondim Jr., Flechtmann \& Moraes, 2000}

Espécie descrita de S. romanzoffiana, Pariquera-Açu, São Paulo, Brasil. Os ácaros foram coletados na superfície inferior dos folíolos (Gondim Jr., Flechtmann \& Moraes, 2000). Neste trabalho (Capítulo 3) espécimes de P. syagris foram também coletados em: folíolos e broto terminal de A. aculeatissimum, em Teresópolis, Rio de Janeiro e em Pariquera-Açu e Cananéia, São Paulo, assim como em folíolos de $B$. vulgaris, em Pariquera-Açu e Cananéia, São Paulo, Brasil. 


\section{Retracrus elaeis Keifer, 1975}

Espécie descrita de E. guineensis, de San Alberto, Bucaramanga, Colômbia. Os ácaros foram relatados causando intenso mosqueamento dos folíolos com manchas escuras, as quais posteriormente tornam-se amarelas ou alaranjadas (Keifer, 1975b). Algumas folhas podem secar completamente. Os danos provocados pelas infestações causam redução na produção desta palmeira, o dendê. Esta espécie também foi relatada infestando folíolos de C. nucifera, na Colômbia (Genty \& Reyes, 1977 ) e em Costa Rica (Salas ${ }^{5}$ comunicação pessoal citado por Schliesske, 1988). Outro hospedeiro relatado para R. elaeis na Costa Rica é B. gasipaes (Ochoa et al.,1994). Neste estudo (Capítulo 3) foram identificados espécimes desta espécie de E. guineensis, de Puntarenas, e de Chamaedorea costaricana Oerst. de San José, Costa Rica.

\section{Retracrus johnstoni Keifer, 1965}

Espécie tipo do gênero, descrita de Chamaedorea sp., de material originário de Tuxtla ou Chiapas, México, próximo à fronteira com a Guatemala, e interceptados pelo serviço de quarentena de San Antonio, Texas, EUA. Os ácaros foram encontrados formando colônias na superfície inferior dos folíolos, causando manchas escuras visíveis em ambas superfícies folhares (Keifer, 1965). Na Costa Rica, a espécie foi relatada infestando C. elegans (Schliesske, 1988), Chamaedorea sp., e C. costaricana Oerst. (Ochoa et al, 1994). No Brasil, esta espécie foi relatada infestando C. nucifera (Santana et al., 1994) e S. romanzoffiana (Santana \& Flechtmann, 1998). Novos hospedeiros de $R$. johnstoni no Brasil foram relatados em Gondim Jr. (2000): E. guineensis, em Igarassu e Recife, Pernambuco; Euterpe sp., em Igarassu e Recife, Pernambuco; e B. setosa, E. edulis, G. schottiana, A. aculeatissimum; B. gasipaes; G. gamiovora e Geonoma pohliana Mart., em São Paulo, Brasil. No presente estudo (Capítulo 3), foram identificados espécimes de R. johnstoni de folhas de B. gasipaes, Limón, Costa Rica; de

${ }^{5}$ SALAS, L. A. (Laboratorio de Acarología e Namatología, Escuela de Fitotecnia, Facultad de Agronomia, Universidad de Costa Rica.) Comunicação pessoal, 1985. 
E. oleracea e Scheelea sp., Piracicaba, São Paulo, Brasil; e de Euterpe precatoria Mart. e Mauritia flexuosa L., Manaus, Amazonas, Brasil.

\section{CHAVE PARA AUXILIAR A SEPARAÇÃO DAS ESPÉCIES DE ERIOPHYOIDEA RELATADOS EM PALMEIRAS}

1. Escudo dorsal com setas anteriores (ve) presentes; setas verticais internas (vi) ausentes. Gnatossoma de tamanho variável, freqüentemente grande, mas com quelíceras retas ou gradualmente curvadas PHYTOPTIDAE Murray

-- Escudo dorsal sem setas anteriores (vi ou ve). Gnatossoma variável 2

2. Gnatossoma geralmente pequeno em relação ao corpo; quando grande, as quelíceras são retas ou levemente curvadas. Cobertura da genitália da fêmea geralmente apresenta linhas (carenas) longitudinais ERIOPHYIDAE Nalepa -- Gnatossoma grande em relação ao corpo; quelíceras abruptamente curvadas na região próxima à base e direcionadas para baixo. Cobertura da genitália da fêmea geralmente lisa DIPTILOMIOPIDAE Keifer

\section{PHYTOPTIDAE}

1. Corpo fusiforme e frequentemente achatado. Anéis do opistossoma geralmente largos, com diferenciação dorso-ventral Sierraphytoptinae Keifer

Seta opistossomal $c 1$ ausente Mackiellini Keifer, 1946 3

-- Corpo vermiforme. Anéis opistossomais estreitos e sub-iguais dorsoventralmente. Seta opistossomal $c 1$ presente Phytoptinae Murray Fêmur e genu separados, não fundidos. Setas escapulares ( $s c$ ) e tubérculos diminutos. Escudo dorsal com glândulas médio-posteriores Acathrix Keifer, 1962 ... 2 
2. Linhas longitudinais sinuosas por toda a área do escudo dorsal. Ausência de lobo frontal. Empódios com 11-12 raios Acathrix trymatus Keifer -- Linhas longitudinais sinuosas apenas na região posterior do escudo; área central lisa. Presença de lobo frontal. Empódios com 9 raios Acathrix lobata Navia \& Flechtmann

3. Setas escapulares (sc) e tubérculos ausentes 4

-- Setas escapulares (sc) e tubérculos presentes 8

4. Setas verticais externas (ve) do escudo dorsal nas margens anteriores dos ângulos umerais. Ausência de estruturas em forma de olhos no escudo dorsal. Anéis opistossomais dorsais muito mais largos que os ventrais ....... Propilus Keifer ............. 5 -- Setas verticais externas (ve) não como acima. Proeminentes estruturas em forma de olhos na região póstero-lateral do escudo dorsal. Anéis opistossomais dorsais e ventrais sub-iguais Palmiphytoptus Navia \& Flechtmann única espécie do gênero Palmiphytoptus oculatus Navia \& Flechtmann

5. Projeções laterais dos anéis opistossomais dorsais bem desenvolvidas, em forma de espinhos 6

-- Projeções laterais dos anéis opistossomais dorsais moderadas, não em forma de espinhos

6. Setas verticais externas (ve) não visíveis dorsalmente, na curvatura antero-ventral do escudo dorsal. Epigínio liso, sem estrias longitudinais. Lobo frontal bem desenvolvido, acuminado Propilus spinosus Keifer

-- Setas verticais externas (ve) visíveis dorsalmente, nos ângulos umerais do escudo dorsal. Epigínio com estrias longitudinais. Lobo frontal pouco desenvolvido, arredondado apicalmente Propilus syagris Gondim Jr., Flechtmann \& Moraes 
7. Lobo frontal subtriangular e apicalmente acuminado. Epigínio basalmente coberto por uma membrana transversalmente estriada. Empódios com 9 raios Propilus pellitus Navia \& Flechtmann

-- Lobo frontal pouco desenvolvido e arredondado apicalmente. Epigínio não coberto por membrana basal. Empódios com 3 raios

Propilus gentyi Keifer

8. Setas escapulares ( $s c$ ) e setas verticais externas (ve) com tubérculos bem desenvolvidos, bulbosos, direcionando as setas ve para frente e as setas sc para trás Retracrus Keifer .

-- Setas escapulares $(s c)$ e verticais externas (ve) com tubérculos normais, direcionando todas as setas para frente Mackiella Keifer 10

9. Banda transversal de linhas longitudinais curtas na base do epigínio. Linhas delicadas na área central do escudo dorsal Retracrus elaeis Keifer -- Ausência de banda de linhas longitudinais na base do epigínio, que é todo liso. Escudo dorsal sem linhas Retracrus johnstoni Keifer 10. Opistossoma com diferenciação dorso-ventral; tergitos largos com microtubérculos alongados, como linhas longitudinais; espaçados. Empódios com 7 raios Mackiella phoenicis Keifer -- Ospistossoma sem diferenciação dorso ventral; anéis contínuos lateralmente e $\begin{array}{llllll}\text { uniformemente microtuberculados. } & \text { Empódios } & \text { com } & 6 & \text { raios }\end{array}$ Mackiella borasis Mohanasundaram

\section{ERIOPHYIDAE*}

* Todos os Eriophyidae que infestam palmeiras apresentam a tíbia distinta do tarso, seta da tíbia $\left(l^{\prime}\right)$ geralmente presente. Escudo dorsal não reduzido e com tubérculos. 
1. Genitália da fêmea aproximada às coxas, separando-as mais que o normal e, em vista lateral, projetada ventralmente. Linha esternal encurtada. Epigínio geralmente com duas séries de linhas longitudinais Cecidophyinae Keifer Setas escapulares $(s c)$ e tubérculos presentes Colomerini Newkirk \& Keifer Corpo vermiforme. Escudo dorsal sem lobo frontal. Setas escapulares (sc) direcionadas para frente, para o centro ou para os lados, mas não para trás. Todas as setas das pernas e do opistossoma presentes Colomerus Newkirk \& Keifer Tubérculos dorsais posicionados à frente da margem posterior do escudo. Manchas ocelares na região lateral do escudo dorsal Colomerus novahebridensis Keifer -- Genitália da fêmea não aproximada às coxas ou separando-as e, em vista lateral, não se projeta ventralmente além do nível do corpo. Linha esternal não encurtada. Epigínio com ornamentação variável, linhas longitudinais não em duas séries 2

2. Corpo vermiforme; anéis sub-iguais dorso-ventralmente, pelo menos na metade ou nos dois terços anteriores do opistossoma. Geralmente, escudo dorsal sem lobo frontal ou com apenas uma leve projeção na base do gnatossoma. Se o lobo frontal está presente, é estreito, com uma linha basal (flexível) e os anéis do corpo são estreitos Eriophyinae Nalepa

-- Corpo geralmente fusiforme. Opistossoma com anéis dorsais largos e lisos e anéis ventrais estreitos e microtuberculados. Escudo dorsal geralmente com um lobo frontal rígido e com a base larga. Se o lobo frontal é ausente (ou pouco desenvolvido), os anéis diferem dorsoventralmente pelo menos em microtubérculos dorsais maiores que os ventrais ou a largura dos anéis é próxima à do comprimento do epigínio

3. Escudo dorsal com tubérculos das setas escapulares (sc) mais ou menos à frente da margem posterior; $s c$ direcionadas para frente ou para cima. Se as $s c$ e os tubérculos estão sobre ou muito próximos à margem posterior do escudo, as bases são longitudinais, e as sc são direcionadas para frente 
-- Escudo dorsal com tubérculos das setas escapulares $(s c)$ sobre ou muito próximos à margem posterior, com as bases transversais; sc direcionadas para trás, geralmente divergindo Aceriini Amrine \& Stasny Seta da tíbia I ( $\left.l^{\prime}\right)$ presente. Seta coxal $1 b$ presente. Dorso do opistossoma uniformemente arqueado em seção transversal. Região posterior do opistossoma com anéis contínuos e sub-iguais dorsoventralmente. Algumas espécies com lobo frontal pouco desenvolvido e com a base flexível Aceria Keifer 4

4. Escudo dorsal com linhas longitudinais ocupando toda a área central ...................... 5

-- Escudo dorsal sem linhas longitudinais ocupando a área central do escudo ................ 6

5. Genitália da fêmea apresentando grânulos na região anterior. Empódios com 8 raios pareados e um não pareado, no ápice Aceria biornata Navia \& Flechtmann -- Genitália da fêmea sem grânulos na região anterior. Empódios com 6 raios pareados Aceria guerreronis Keifer

6. Com as pernas robustas e o corpo levemente fusiforme, assemelhando-se a uma protogina de Cisaberoptus Keifer, 1966. Epigínio com linhas transversais pontuadas na região anterior. Ausência de lobo frontal Aceria translinea Navia \& Flechtmann -- Pernas normalmente desenvolvidas, corpo tipicamente vermiforme. Epigínio com linhas longitudinais. Lobo frontal subtriangular, com linha basal (flexível) Aceria gymnoscuta Navia \& Flechtmann

7. Seta coxal $1 b$ ausente. Setas escapulares (sc) direcionadas antero-lateralmente e bases dos tubérculos longitudinais. Lobo frontal pouco desenvolvido. Seta do genu I ( $\left.l^{\prime}\right)$ mais curta que o comprimento da perna I Nacerimina Keifer Região coxi-genital ornamentada com linhas curtas interrompidas. Epigínio com cerca de 14 linhas longitudinais. Empódios com 7 raios Nacerimina gutierrezi Keifer 
-- Seta coxal $1 b$ presente. Base dos tubérculos das setas escapulares (sc) variáveis. Escudo dorsal com lobo frontal. Lobo frontal bem desenvolvido, triangular com as margens laterais retas ou côncavas. Seta do genu I ( $\left.l^{\prime \prime}\right)$ mais longa que o comprimento da perna I Proartacris Mohanasundaram Corpo estreito e alongado. Ausência de microtubérculos nos anéis opistossomais dorsais Proartacris longior Navia \& Flechtmann

8. Empódios divididos Acaricalini Amrine \& Stasny....9

-- Empódios inteiros 14

9. Setas escapulares ( $s c)$ ausentes. Setas da tíbia( $\left.l^{\prime}\right)$, do genu II $\left(l^{\prime \prime}\right)$, do fêmur $(b v)$ e

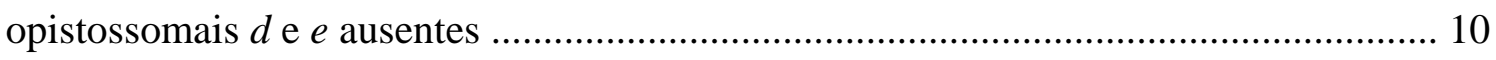

-- Setas escapulares $(s c)$ presentes. Demais setas variáveis ..................................... 11

10. Opistossoma com uma elevação longitudinal central sem depressão mediana; Anéis opistossomais vistos dorsalmente, com projeções laterais de modo não uniforme Knorella Keifer Área triangular lateral ao coxiesterno II microtuberculada. Epigínio com estrias longitudinais apenas na região basal. Opistossoma com projeções laterais nos anéis 2, 4, 7, 10, 12, e 15 ....................... Knorella geonomae Gondim Jr., Flechtmanna \& Moraes -- Opistossoma com uma elevação longitudinal que se estende pelos 4 anéis anteriores, seguido de uma larga depressão mediana. Anéis opistossomais vistos dorsalmente, com projeções laterais uniformes Schizacea Keifer Empódios bipartidos, com 7-8 raios em cada ramo. Cinco anéis coxi-genitais lisos Schizacea geonomae Navia \& Flechtmann

11. Opistossoma com vários anéis fundidos, próximos ao escudo dorsal, formando uma placa. Os primeiros três anéis opistossomais separados e estreitos, seguidos de cerca de dez anéis fundidos, formando uma área expandida tão larga quanto o escudo. Setas 
opistossomais $c 2$ presente e seta $d$ ausente. Setas escapulares (sc) não em forma de espinhos Tumescoptes Keifer ... 12

-- Opistossoma com vários anéis fundidos, imediatamente após o escudo dorsal, formando um "escudo expandido". Setas opistossomais $c 2$ ausente e seta $d$ presente. Setas escapulares (sc) em forma de espinhos Nasuchus Navia \& Flechtmann única espécie do gênero Nasuchus pindobates Navia \& Flechtmann

12. Parte posterior do dorso do opistossoma (após placas formadas pela fusão de anéis) sem elevações ou depressões Tumescoptes phoenixi Meyer -- Parte posterior do dorso do opistossoma (após placas formadas pela fusão de anéis) com elevações ou depressões

13. Parte posterior do dorso do opistossoma (após placas formadas pela fusão de anéis) com uma depressão mediana e duas elevações laterais. Setas unguinais $(u)$ dos tarsos bifurcadas Tumescoptes dicrus Meyer

-- Parte posterior do dorso do opistossoma (após placas formadas pela fusão de anéis) com uma elevação mediana. Setas unguinais $\left(u^{\prime}\right)$ dos tarsos não bifurcadas Tumescoptes trachycarpi Keifer

14. Setas escapulares (sc) ausentes. Tubérculos presentes ou ausentes Calacarini Amrine \& Stasny Anéis do opistossoma não se projetando lateralmente em vista dorsal. Opistossoma com três elevações dorsais. Elevação mediana estreita, tão longa quanto as elevações laterais. Seta da tíbia I $\left(l^{\prime}\right)$ presente. Opistossoma gradualmente afilado Calacarus Keifer única do gênero associada a palmeiras Calacarus palmae Mohanasundaram 
15. Opistossoma visto dorsalmente com projeções ou lobos pontiagudos em alguns ou todos os anéis, ou com uma placa atrás do escudo dorsal com extensões laterais Tegonotini Bagdasarian 16

-- Opistossoma visto dorsalmente sem projeções ou lobos pontiagudos; ausência de placa atrás do escudo dorsal com extensões laterais 18

16. Anéis do opistossoma não fundidos. Escudo dorsal sem projeções posteriores sobre o opistossoma. Anéis opistossomais não em forma de espinhos. Seta coxal $1 b$ presente. Escudo dorsal não separado do opistossoma por uma depressão transversal. Setas escapulares $(s c)$ posicionadas à frente da margem posterior do escudo dorsal. Seta da tíbia I ( 1 ) presente. Lobo frontal não emarginado Tegonotus Nalepa Empódios com 7 raios. Epigínio com linhas curtas distribuídas irregularmente. Setas SC direcionadas centralmente Tegonotus gutierrezi Boczek \& Natcheff -- Anéis anteriores do opistossoma fundidos. Demais características variáveis 17

17. Anéis anteriores do opistossoma fundidos formando uma placa larga unida ao escudo dorsal, sem projeções em forma de espinhos Glabrisceles Navia \& Flechtmann única espécie do gênero Glabrisceles euterpis Navia \& Flechtmann -- Anéis anteriores do opistossoma fundidos formando uma placa larga unida ao escudo dorsal, com três projeções em forma de espinhos Scolocenus Keifer única espécie do gênero Scolocenus spiniferus Keifer

18. Tubérculos das setas escapulares $(s c)$ inseridos à frente da margem posterior do escudo, direcionando as setas para trás, para cima ou convergentemente; se os tubérculos e as setas estão próximas às margens posteriores do escudo dorsal, estes são subcilíndricos e suas bases são longitudinais ou diagonais em relação ao corpo Phyllocoptini Nalepa 30

-- Tubérculos das setas escapulares $(s c)$ sobre ou muito próximos à margem posterior do escudo, direcionando as setas para trás, geralmente divergentemente, subcilíndricos, com 
as

bases transversais

em

relação

ao

corpo

Anthocoptini Amrine \& Stasny

Dorso do opistossoma com uma larga depressão mediana longitudinal. Escudo dorsal sem projeção posterior. Seta coxal $1 b$ presente. Seta do genu II $\left(l^{\prime \prime}\right)$ ausente Notostrix Keifer

19. Epigínio com duas séries transversais de linhas longitudinais Notostrix exigua Flechtmann -- Epigínio com uma única série de linhas longitudinais, a qual pode ocupar toda a área do epigínio ou a região basal pode ser granulada ou apresentar linhas curtas quebradas

20. Setas escapulares curtas (sc) ( $\leq 8 \mu \mathrm{m}$ de comprimento), não alcançando a margem posterior do escudo dorsal ...................................................................................... 21

-- Setas escapulares longas (>8 $\mu \mathrm{m}$ de comprimento), geralmente alcançando ou estendendo-se além da margem do escudo dorsal 25

21. Empódios divididos, bipartidos. Na perna I, a seta da tíbia $\left(l^{\prime}\right)$ é mais ou tão longa quanto a seta lateral do tarso $\left(f t^{\prime \prime}\right)$ Notostrix fissipes Navia \& Flechtmann -- Empódios não-divididos (inteiros) ou tripartidos. Na perna I, o comprimento da seta da tíbia ( $\left.l^{\prime}\right)$ é variável 22

22. Empódios tripartidos. Epigínio granulado basalmente, com linhas longitudinais convergentes posteriormente. Setas escapulares ( $s c)$ diminutas ( $2 \mu \mathrm{m}$ de comprimento), que podem estar cobertas por cera Notostrix miniseta Navia \& Flechtmann -- Empódios não dividido (inteiro). Epigínio variável. Setas escapulares medindo de 2 a $8 \mu \mathrm{m}$ de comprimento 23

23. Epigínio com um padrão de linhas curvas curtas na região basal, um pouco separadas da série apical de 18-20 linhas longitudinais Notostrix jamaicae Keifer 
-- Epigínio com grânulos ou linhas longitudinais quebradas na região basal

24. Epigínio com uma série de 15-19 linhas longitudinais, quebradas na região basal, as quais ocupam todo a área do mesmo.

Notostrix butiae Gondim Jr., Flechtmann \& Moraes

-- Epigínio com um padrão de grânulos na região basal e uma série de 12-14 linhas longitudinais na metade apical

.Notostrix nasutiformes Gondim Jr., Flechtmann \& Moraes

25. Escudo dorsal ornamentado com grânulos; linhas presentes ou ausentes 26

-- Escudo dorsal ornamentado apenas com linhas

26. Escudo dorsal arredondado anteriormente, totalmente coberto com grânulos circulares Notostrix flabelliferae Mohanasundaram -- Escudo dorsal anteriormente pontiagudo, com grânulos irregulares, que são alongados em algumas áreas, e cobertos por cera; ornamentação restrita à região central, delimitada pela linha submarginal Notostrix acuminata Navia \& Flechtmann

27. Empódios tripartidos; ramos laterais com raios e ramo central sem raios, mas apicalmente bifurcado. Seta femural (bv) angulada Notostrix trifida Navia \& Flechtmann

-- Empódios não divididos. Setas femurais (bv) retas 28

28. Epigínio granulado na região basal. Setas escapulares $(s c)$ estendendo-se até o $3^{\circ}$ ou $4^{\circ}$ anel anterior dorsal Notostrix longiseta Navia \& Flechtmann -- Epigínio sem grânulos. Setas escapulares (sc) não se estendendo até o $3^{\circ}$ ou $4^{\circ}$ anel anterior dorsal 29 
29. Epigínio com linhas longitudinais distintamente divergentes na região basal. Região coxal da fêmea com linhas curvas, sem grânulos Notostrix attenuata Keifer -- Epigínio com linhas não divergentes na região basal. Região coxal da fêmea granulada e com linhas curtas delicadas Notostrix vazquezae Navia \& Flechtmann

30. Escudo dorsal com uma projeção posterior longa e estreita, estendendo-se sobre os primeiros 8 anéis, levemente curvada para um dos lados. Dorso do opistossoma com uma depressão mediana flanqueada por depressões subdorsais mais largas. Setas da tíbia I $\left(l^{\prime}\right)$ e coxal $1 b$ presentes ................... Gilarovella Mitrofanov, Sekerskaya \& Sharonov única espécie do gênero ..... Gilarovella caniculata Mitrofanov, Sekerskaya \& Sharonov -- Escudo dorsal sem projeções. Demais características variáveis 31

31. Dorso do opistossoma com três elevações longitudinais 32

-- Dorso do opistossoma sem elevações. .38

32. Setas femurais $(b v)$ e setas opistossomais $c 2$ e $e$ ausentes. Epigínio com linhas curtas; dividido longitudinalmente, apresentando a forma de um “w” arredondado. Solenídio do tarso curto e com a extremidade expandida Amrineus Flechtmann 33

-- Setas femurais $(b v)$ e todas as setas do opistossoma presentes. Demais características variáveis 34

33. Epigínio com linhas longitudinais. Cinco anéis coxi-genitais Amrineus coconuciferae (Keifer) -- Epigínio sem linhas longitudinais longas, apenas com linhas curtas dispersas. Oito a nove anéis coxi-genitais Amrineus cocofolius Flechtmann 34. Elevação mediana termina antes que as elevações subdorsais, em uma larga depressão Calepitrimerus Keifer Setas escapulares (sc) convergentes. Epigínio com duas séries transversais de linhas longitudinais. Empódios com 4 raios Calepitrimerus livistonae Wei \& Feng 
-- Elevação mediana tão longa quanto as elevações subdorsais. Depressões subdorsais rasas, fazendo com que as elevações dorsais sejam pouco acentuadas

35. Escudo dorsal ornamentado com muitas linhas curtas; linhas admedianas estendemse da margem porterior do escudo até o terço apical, bifurcadas apicalmente Epitrimerus englerus Huang

-- Escudo dorsal não ornamentado com linhas curtas; demais características variáveis 36

36. Escudo dorsal com estensão mediana na região posterior, interrompendo os primeiros anéis dorsais ou arqueando-os medianamente. Empódios com até 4 raios .... 37 -- Escudo dorsal sem estensão mediana na região posterior. Empódios com mais de 4 raios Epitrimerus elaeis Boczek \& Natcheff

37. Epigínio com linhas longitudinais. Empódios com 4 raios ..... Epitrimerus calami Keifer -- Epigínio sem linhas longitudinais, liso. Empódios com 2 raios Epitrimerus steveni Mitrofanov, Sekerskaya \& Sharonov

38. Dorso do opistossoma com depressões longitudinais 39

-- Dorso do opistossoma sem depressões longitudinais 41

39. Dorso do opistossoma com depressões longitudinais medianas e subdorsais. Setas opistossomais $d$ e $e$ ausentes Neocupacarus Das \& Chakrabarti única espécie do gênero Neocupacarus flabelliferis Das \& Chakrabarti -- Dorso do opistossoma com uma depressão mediana ladeada por elevações com glândulas ceríferas. Setas opistossomais $d$ e $e$ presentes Adenoptus Mitrofanov, Sekerskaya \& Sharanov .... 40 
40. Seta antapical (d) bifurcada. Primeiros 5-6 anéis opistossomais dorsais sem depressões medianas e uniformemente microtuberculados; a depressão mediana inicia-se após estes anéis. Empódios com 3 raios. Epigínio com textura levemente irregular, como se porosa Adenoptus migeoni Navia \& Flechtmann -- Seta antapical $(d)$ aparentemente não bifurcada. Opistossoma com depressão mediana que se inicia imediatamente após a margem posterior do escudo; ausência de microtubérculos na região da depressão mediana. Empódios com 2 raios. Epigínio liso Adenoptus chamaeropsi Mitrofanov, Sekerskaya \& Sharonov

41. Opistossoma com anéis dorsais desorganizados na região central Acritonotus Keifer empódios com 3 raios; escudo dorsal não ornamentado; ausência de seta acessória Acritonotus denmarki Keifer -- Opistossoma com anéis dorsais organizados na região central Phyllocoptes Nalepa Empódios com 3 raios, palmados. Escudo dorsal com algumas linhas na região lateral. Região distal do epigínio com linhas côncavas, transversais, em dois blocos; região basal com linhas irregulares, oblíquas, convergentes Phyllocoptes mariaui Boczek \& Natcheff

\section{DIPTILOMIOPIDAE*}

* Todos os Diptilomiopidae que infestam palmeiras apresentam os empódios divididos. Todas as setas das coxas presentes. Pernas com seis segmentos; tíbia distinta, não fundida ao tarso.

1. Setas escapulares ( $s c$ ) ausentes; tubérculos presentes ou ausentes. Setas da tíbia I ( $\left({ }^{\prime}\right)$ e do genu II ( $\left.l^{\prime \prime}\right)$ presentes ou ausentes 
-- Setas escapulares $(s c)$ e tubérculos presentes. Setas da tíbia I $\left(l^{\prime}\right)$ e do genu II $\left(l^{\prime}\right)$

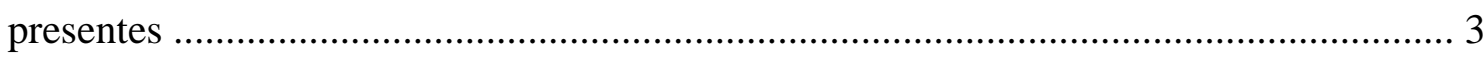

2. Seta opistossomal $c_{2}$ ausente. Opistossoma sem elevações longitudinais. Setas da tíbia I $\left(l^{\prime}\right) \quad$ e do genu II $\left(l^{\prime}\right)$ ausentes

Davisella Flechtmann, Amrine \& Stasny Escudo dorsal liso, com dois círculos ou anéis na região central próxima à margem posterior. Epigínio mais largo do que a distância entre os ângulos externos da coxa II Davisella palmea (Flechtmann)

-- Seta opistossomal $c_{2}$ presente. Opistossoma com cinco elevações longitudinais com glândulas ceríferas. Setas da tíbia I $(l)$ e do genu II $\left(l^{\prime \prime}\right)$ presentes Neodialox Mohanasundaram única espécie do gênero Neodialox palmyrae Mohanasundarm

3. Lobo anterior do escudo dorsal emarginado. Escudo dorsal com dois sulcos transversais pronunciados, sendo um próximo à margem posterior e outro sobre a margem posterior. Tíbia distintamente longa Dialox Keifer única espécie do gênero Dialox stellatus Keifer 1962 -- Lobo anterior do escudo dorsal não emarginado. Escudo dorsal sem sulcos transversais na região da margem posterior. Dorso do opistossoma com uma leve elevação central. Tíbia não como acima Diptacus Keifer Empódios dividido em 2 ramos com 3 raios cada Diptacus borinquensis Cromroy

Das 57 espécies de Eriophyoidea relatadas em Arecaceae, apenas seis foram mencionadas no continente africano, associadas a dois hospedeiros, sendo as demais relatadas nas Américas, sudeste Asiático, Europa ou Oceania (Tabela 1). Na Europa, a diversidade de palmeiras é extremamente limitada (Jones, 1995). Talvez, devido a isso, apenas quatro espécies de Eriophyoidea foram relatadas de um único hospedeiro, 
Chamaerops humilis L., naquele continente. Entretanto, na África, onde ocorre um maior número de gêneros e espécies de palmeiras (Jones, 1995), também é reduzido o número de Eriophyoidea relatados em plantas deste grupo. Observa-se portanto uma lacuna de informações sobre os ácaros deste grupo associados às palmeiras no continente africano.

Entre os Eriophyoidea associados às palmeiras, até o momento apenas quatro espécies foram consideradas causando danos significativos aos seus hospedeiros: $A$. guerreronis, C. novahebridensis, R. elaeis e R. johnstoni.

A palmeira à qual maior número de espécies de Eriophyoidea foram relatadas é C. nucifera (Tabela 1). Até o momento foram reportadas 15 espécies de Eriophyoidea (11 Eriophyidae, 3 Phytoptidae, 1 Diptilomiopidae) em folhas, frutos e broto terminal desta planta nas Américas, no sudeste da Ásia, na África e na Oceania. Este grande número de espécies de Eriophyopidea associados a $C$. nucifera provavelmente se deve à sua ampla distribuição geográfica e ao maior esforço amostral dedicado a esta espécie vegetal, devido à sua importância econômica. Praticamente todas as espécies associadas a C. nucifera ocorrem em regiões geográficas restritas, exceto A. guerreronis, que até o momento foi constatada nas Américas, África e no sudeste da Ásia, isto é, em quase todos os continentes onde o coqueiro é encontrado.

Observou-se que algumas espécies de Eriophyoidea apresentam um grande número de hospedeiros entre as Arecaceae, detacando-se: $R$. johnstoni, em 19 espécies de palmeiras pertencentes a 10 gêneros; $N$. butiae, em 6 espécies de 3 gêneros; $N$. nasutiformes, em 5 espécies de 3 gêneros; A. cocofolius, em 5 espécies de 4 gêneros; e A. guerreronis, em 4 espécies de 4 gêneros. Das espécies de Eriophyoidea associadas às palmeiras, 17 foram encontradas em 2 ou mais hospedeiros de gêneros distintos. Estas espécies pertencem aos gêneros Aceria, Acritonotus, Amrineus, Davisella, Notostrix, Palmiphytoptus, Propilus e Retracrus. Cada uma das demais espécies de Eriophyoidea foi até agora relatada em espécies pertencentes a um gênero. Uma baixa especificidade hospedeira (infestação de hospedeiros de gêneros distintos) também têm sido relatada para alguns outros Eriophyoidea, especialmente entre aqueles que infestam monocotiledôneas (Amrine Jr. \& de Lillo, 2003; Oldfield, 1996). 
As espécies que compõem o gênero Retracrus são morfologicamente muito semelhantes, sendo diferenciadas por detalhes do escudo dorsal e do epigínio, os quais nem sempre são visíveis. Espécimes de Retracrus coletados de uma espécie hospedeira, de uma dada região, tem sido identificadas por alguns sistematas como $R$. elaeis e por outros como R. johnstoni, como por exemplo espécimes coletados de C. costaricana de Costa Rica, identificados como $R$. elaeis por R. Ochoa e como $R$. johnstoni por Flechtmann \& Navia. É possível que as espécies ocorram conjuntamente. Por outro lado é também possível que as espécies estejam sendo erroneamente identificadas. Estudos mais detalhados, utilizando métodos morfométricos e/ou moleculares devem ser realizados para esclarecer melhor a sistemática deste gênero de importância econômica e quarentenária.

Uma espécie de palmeira pode apresentar frutos, folhas e brotos terminais infestados por diferentes espécies de eriofiídeos (Tabela 1). Portanto, para que se conheça a fauna de Eriophyoidea associada a uma determinada palmeira é necessário amostrar todas as partes da planta. Observa-se também que algumas espécies de Eriophyoidea infestam órgãos distintos de hospedeiros diferentes.

Um grande número de espécies de Eriophyoidea associadas às palmeiras foi relatado no Brasil. Isto se deve aos esforços de levantamentos realizados especialmente nos últimos dez anos. A diversidade de palmeiras no Brasil é bastante alta. Entre as 132 espécies nativas, pelo menos 51 foram analisadas em algumas de suas áreas de distribuição, encontrando-se Eriophyoidea associados a 28 destas.

Maiores esforços deverão ser direcionados para ampliar o conhecimento da fauna de Eriophyoidea associada às palmeiras por todo o mundo. Isto possibilitaria um melhor manejo das áreas de cultivo das plantas deste grupo em agroecossitemas em que estes ácaros venham a assumir importância econômica. 
Tabela 1. Ácaros Eriophyoidea em palmeiras no mundo. Hospedeiros, espécies associadas, órgãos infestados (FOL- folhas; BT - brotos terminais; FRU- frutos), países de ocorrência e referências

\begin{tabular}{|c|c|c|c|c|}
\hline Hospedeiro & Espécie & Órgão & País & Referência \\
\hline \multirow[t]{3}{*}{ Acrocomia aculeata } & Aceria biornata & $\mathrm{BT}$ & Brasil & $\begin{array}{l}\text { Navia \& } \\
\text { Flechtmann (2002) }\end{array}$ \\
\hline & Notostrix acuminata & FOL & Brasil & $\begin{array}{l}\text { Navia \& } \\
\text { Flechtmann (2003) }\end{array}$ \\
\hline & Notostrix attenuata & FOL & Brasil & Gondim Jr. (2000) \\
\hline \multirow[t]{2}{*}{ Aiphanes sp. } & Propilus gentyi & FOL & Colômbia & Keifer (1975) \\
\hline & Propilus spinosus & FOL & Colombia & Keifer (1975) \\
\hline Arenga englera & Epitrimerus englerus & FOL & Taiwan & Huang (2001) \\
\hline Astrocaryum & Retracrus johnstoni & FOL & Brasil & Gondim Jr. (2000) \\
\hline \multirow[t]{3}{*}{ aculeatissimim } & $\begin{array}{l}\text { Palmiphytoptus } \\
\text { oculatus }\end{array}$ & FOL & Brasil & $\begin{array}{l}\text { Navia \& } \\
\text { Flechtmann (2002) }\end{array}$ \\
\hline & Propilus gentyi & FOL & Brasil & Gondim Jr. (2000) \\
\hline & Propilus syagris & FOL, BT & Brasil & Capítulo 3 \\
\hline \multirow[t]{3}{*}{ Attalea dubia } & Aceria translinea & BT & Brasil & $\begin{array}{l}\text { Navia \& } \\
\text { Flechtmann (2002) }\end{array}$ \\
\hline & Notostrix fissipes & FOL & Brasil & $\begin{array}{l}\text { Navia \& } \\
\text { Flechtmann (2003) }\end{array}$ \\
\hline & $\begin{array}{l}\text { Notostrix } \\
\text { nasutiformes }\end{array}$ & FOL & Brasil & $\begin{array}{l}\text { Gondim Jr. et al. } \\
\text { (2000) }\end{array}$ \\
\hline \multirow[t]{2}{*}{ Attalea geraensis } & Amrineus cocofolius & FOL & Brasil & Capítulo 3 \\
\hline & Notostrix butiae & FOL & Brasil & Capítulo 3 \\
\hline Attalea phalerata & $\begin{array}{l}\text { Notostrix } \\
\text { nasutiformes }\end{array}$ & FOL & Brasil & $\begin{array}{l}\text { Gondim Jr. et al. } \\
\text { (2000) }\end{array}$ \\
\hline Attalea sp. & Notostrix jamaicae & FOL & Brasil & $\begin{array}{l}\text { Santana \& } \\
\text { Flechtmann (1998) }\end{array}$ \\
\hline Bactris ferruginea & $\begin{array}{l}\text { Notostrix } \\
\text { nasutiformes }\end{array}$ & FOL & Brasil & $\begin{array}{l}\text { Gondim Jr. et al. } \\
\text { (2000) }\end{array}$ \\
\hline \multirow[t]{3}{*}{ Bactris gasipaes } & $\begin{array}{l}\text { Notostrix } \\
\text { nasutiformes }\end{array}$ & FOL & Brasil & $\begin{array}{l}\text { Gondim Jr. et al. } \\
\text { (2000) }\end{array}$ \\
\hline & Retracrus elaeis & FOL & Costa Rica & Ochoa et al. (1994) \\
\hline & Retracrus johnstoni & FOL & $\begin{array}{l}\text { Brasil, } \\
\text { Costa Rica }\end{array}$ & $\begin{array}{l}\text { Gondim Jr. (2000); } \\
\text { Capítulo } 3\end{array}$ \\
\hline \multirow[t]{6}{*}{ Bactris setosa } & Notostrix exigua & FOL, BT & Brasil & Capítulo 3 \\
\hline & Notostrix miniseta & FOL & Brasil & $\begin{array}{l}\text { Navia \& } \\
\text { Flechtmann (2003) }\end{array}$ \\
\hline & $\begin{array}{l}\text { Notostrix } \\
\text { nasutiformes }\end{array}$ & FOL & Brasil & $\begin{array}{l}\text { Gondim Jr. et al. } \\
\text { (2000) }\end{array}$ \\
\hline & $\begin{array}{l}\text { Palmiphytoptus } \\
\text { oculatus }\end{array}$ & BT & Brasil & $\begin{array}{l}\text { Navia \& } \\
\text { Flechtmann (2002) }\end{array}$ \\
\hline & Propilus spinosus & FOL & Brasil & Gondim Jr. (2000) \\
\hline & Retracrus johnstoni & FOL & Brasil & Gondim Jr. (2000) \\
\hline
\end{tabular}


Tabela 1. Ácaros Eriophyoidea em palmeiras no mundo. Hospedeiros, espécies associadas, órgãos infestados (FOL- folhas; BT - brotos terminais; FRU- frutos), países de ocorrência e referências

\begin{tabular}{|c|c|c|c|c|}
\hline Hospedeiro & Espécie & Órgão & País & Referência \\
\hline \multirow[t]{3}{*}{ Bactris vulgaris } & Notostrix miniseta & FOL & Brasil & $\begin{array}{l}\text { Navia \& } \\
\text { Flechtmann (2003) }\end{array}$ \\
\hline & Propilus gentyi & FOL & Brasil & Capítulo 3 \\
\hline & Propilus syagris & FOL & Brasil & Gondim Jr. (2000) \\
\hline \multirow[t]{5}{*}{ Borassus flabellifer } & Aceria guerreronis & FRU & $\begin{array}{l}\text { India e Sri } \\
\text { Lanka }\end{array}$ & $\begin{array}{l}\text { Ramaraju \& Rabindra } \\
\text { (1991); Moraes \& } \\
\text { Fernando (2003) }\end{array}$ \\
\hline & Mackiella borasis & $\mathrm{BT}$ & India & $\begin{array}{l}\text { Mohanasundaram } \\
\text { (1981) }\end{array}$ \\
\hline & $\begin{array}{l}\text { Neocupacarus } \\
\text { flabellifer }\end{array}$ & FOL & India & $\begin{array}{l}\text { Das \& Chakrabarti } \\
\text { (1985) }\end{array}$ \\
\hline & Neodialox palmyrae & FOL & India & $\begin{array}{l}\text { Mohanasundaram } \\
\text { (1983) }\end{array}$ \\
\hline & Notostrix flabellifer & FOL & India & $\begin{array}{l}\text { Mohanasundaram } \\
\text { (1982) }\end{array}$ \\
\hline \multirow[t]{3}{*}{ Butia archeri } & Amrineus cocofolius & FOL & Brasil & Capítulo 3 \\
\hline & Notostrix butiae & FOL, BT & Brasil & Capítulo 3 \\
\hline & Notostrix longiseta & FOL & Brasil & $\begin{array}{l}\text { Navia \& } \\
\text { Flechtmann (2003) }\end{array}$ \\
\hline Butia capitata & Notostrix butiae & FOL & Brasil & Capítulo 3 \\
\hline \multirow[t]{3}{*}{ Butia eriospatha } & Amrineus cocofolius & FOL & Brasil & Capítulo 3 \\
\hline & Notostrix butiae & FOL & Brasil & $\begin{array}{l}\text { Gondim Jr. et al. } \\
\text { (2000) }\end{array}$ \\
\hline & Proartacris longior & $\mathrm{BT}$ & Brasil & $\begin{array}{l}\text { Navia \& } \\
\text { Flechtmann (2002) }\end{array}$ \\
\hline Calamus australis & Epitrimerus calami & FOL & Austrália & Keifer (1969) \\
\hline Chamaedorea & Retracrus elaeis & FOL & Costa Rica & Capítulo 3 \\
\hline costaricana & Retracrus johnstoni & FOL & Costa Rica & Ochoa et al. (1994) \\
\hline Chamaedorea elegans & Retracrus johnstoni & FOL & Costa Rica & Schliesske (1988) \\
\hline Chamaedorea sp. & Retracrus johnstoni & FOL & $\begin{array}{l}\text { México, } \\
\text { Costa Rica }\end{array}$ & $\begin{array}{l}\text { Keifer (1965); } \\
\text { Ochoa et al. (1994) }\end{array}$ \\
\hline \multirow[t]{4}{*}{ Chamaerops humilis } & $\begin{array}{l}\text { Adenoptus } \\
\text { chamaeropsi }\end{array}$ & ? & Ucrânia & $\begin{array}{l}\text { Mitrofanov et al. } \\
\text { (1983) }\end{array}$ \\
\hline & Adenoptus migeoni & FOL & França & $\begin{array}{l}\text { Navia \& } \\
\text { Flechtmann (2003) }\end{array}$ \\
\hline & Epitrimerus steveni & FOL & Ucrânia & $\begin{array}{l}\text { Mitrofanov et al. } \\
\text { (1983) }\end{array}$ \\
\hline & $\begin{array}{l}\text { Gilarovella } \\
\text { caniculata }\end{array}$ & FOL & Ucrânia & $\begin{array}{l}\text { Mitrofanov et al. } \\
\text { (1983) }\end{array}$ \\
\hline
\end{tabular}

${ }^{6}$ MORAES, G.J.de. (Escola Superior de Agricultura Luiz de Queiroz (ESALQ), Universidade de São Paulo) \& FERNANDO, L.C.P (Coconut Research Institute, Lunuwila, Sri Lanka) (Em elaboração). 
Tabela 1. Ácaros Eriophyoidea em palmeiras no mundo. Hospedeiros, espécies associadas, órgãos infestados (FOL- folhas; BT - brotos terminais; FRU- frutos), países de ocorrência e referências

\begin{tabular}{|c|c|c|c|c|}
\hline Hospedeiro & Espécie & Órgão & País & Referência \\
\hline \multirow[t]{17}{*}{ Cocos nucifera } & Acathrix trymatus & FOL, BT & $\begin{array}{l}\text { Filipinas, } \\
\text { EUA }\end{array}$ & $\begin{array}{l}\text { Keifer (1962c); } \\
\text { Amrine Jr. \& de } \\
\text { Lillo (2003) }\end{array}$ \\
\hline & Aceria guerreronis & FRU & $\begin{array}{l}\text { América, } \\
\text { África, } \\
\text { India e Sri } \\
\text { Lanka }\end{array}$ & $\begin{array}{l}\text { Keifer (1965); } \\
\text { Cabral \& Carmona } \\
\text { (1969); Sathiamma } \\
\text { et al. (1998); } \\
\text { Fernando et al. } \\
\text { (2000) }\end{array}$ \\
\hline & Aceria guerreronis & BT & Brasil & $\begin{array}{l}\text { Aquino \& Arruda } \\
\text { (1969) }\end{array}$ \\
\hline & Acritonotus denmarki & FOL & EUA & $\begin{array}{l}\text { Moore \& Howard } \\
\text { (1996) }\end{array}$ \\
\hline & Amrineus cocofolius & FOL & Brasil & Flechtmann (1994) \\
\hline & Amrineus cocofolius & FRU & $\begin{array}{l}\text { Brasil e } \\
\text { México }\end{array}$ & $\begin{array}{l}\text { Ferreira et al. } \\
\text { (2001); Capítulo } 9\end{array}$ \\
\hline & $\begin{array}{l}\text { Amrineus } \\
\text { coconuciferae }\end{array}$ & FOL & EUA & Keifer (1962b) \\
\hline & $\begin{array}{l}\text { Colomerus } \\
\text { novahebridensis }\end{array}$ & FRU & $\begin{array}{l}\text { Sudeste da } \\
\text { Ásia e } \\
\text { Oceania }\end{array}$ & $\begin{array}{l}\text { Keifer (1977a); Hall } \\
\text { et al. (1980); Kang } \\
\text { (1981); Moore \& } \\
\text { Howard (1996) }\end{array}$ \\
\hline & Dialox stellatus & $\begin{array}{l}\text { FOL, } \\
\text { FRU }\end{array}$ & Filipinas & Keifer (1962a) \\
\hline & Epitrimerus elaeis & $?$ & $\begin{array}{l}\text { Costa do } \\
\text { Marfim }\end{array}$ & $\begin{array}{l}\text { Amrine \& de Lillo } \\
\text { (2003) }\end{array}$ \\
\hline & Nacerimina gutierrezi & FOL & Samoa & Keifer (1979) \\
\hline & Notostrix attenuata & FOL & $\begin{array}{l}\text { Filipinas, } \\
\text { India, Brasil }\end{array}$ & $\begin{array}{l}\text { Keifer (1963); } \\
\text { Mohanasundaram } \\
\text { (1984); Flechtmann } \\
\text { \& Santana (1997) }\end{array}$ \\
\hline & Notostrix jamaicae & FOL & $\begin{array}{l}\text { Jamaica, } \\
\text { Costa Rica }\end{array}$ & $\begin{array}{l}\text { Keifer (1970); } \\
\text { Schliesske (1998) }\end{array}$ \\
\hline & $\begin{array}{l}\text { Notostrix } \\
\text { nasutiformes }\end{array}$ & FOL & $\begin{array}{l}\text { Brasil, } \\
\text { México }\end{array}$ & $\begin{array}{l}\text { Gondim Jr. et al. } \\
\text { (2000); Capítulo } 3\end{array}$ \\
\hline & Retracrus elaeis & FOL & $\begin{array}{l}\text { Colômbia, } \\
\text { Costa Rica }\end{array}$ & $\begin{array}{l}\text { Genty \& Reyes(1977) } \\
\text { Schliesske (1988) }\end{array}$ \\
\hline & Retracrus johnstoni & FOL & Brasil & $\begin{array}{l}\text { Santana et al. } \\
\text { (1994) }\end{array}$ \\
\hline & Scolocenus spiniferus & FOL & Filipinas & Keifer (1962a) \\
\hline
\end{tabular}


Tabela 1. Ácaros Eriophyoidea em palmeiras no mundo. Hospedeiros, espécies associadas, órgãos infestados (FOL- folhas; BT - brotos terminais; FRU- frutos), países de ocorrência e referências

\begin{tabular}{|c|c|c|c|c|}
\hline Hospedeiro & Espécie & Órgão & País & Referência \\
\hline Collinia sp. & Calacarus palmae & $?$ & India & $\begin{array}{l}\text { Mohanasundaram } \\
\text { (1994) }\end{array}$ \\
\hline \multirow[t]{5}{*}{ Elaeis guineensis } & Epitrimerus elais & FOL & $\begin{array}{l}\text { Costa do } \\
\text { Marfim }\end{array}$ & $\begin{array}{l}\text { Boczek \& Natcheff } \\
\text { (1989) }\end{array}$ \\
\hline & Phyllocoptes mariaui & FOL & $\begin{array}{l}\text { Costa do } \\
\text { Marfim }\end{array}$ & $\begin{array}{l}\text { Boczek \& Natcheff } \\
\text { (1989) }\end{array}$ \\
\hline & Retracrus elaeis & FOL & $\begin{array}{l}\text { Colômbia, } \\
\text { Costa Rica }\end{array}$ & $\begin{array}{l}\text { Keifer (1975b); } \\
\text { Capítulo } 3\end{array}$ \\
\hline & Retracrus johnstoni & FOL & Brasil & Gondim Jr. (2000) \\
\hline & Tegonotus gutierrezi & FOL & $\begin{array}{l}\text { Costa do } \\
\text { Marfim }\end{array}$ & $\begin{array}{l}\text { Boczek \& Natcheff } \\
\text { (1989) }\end{array}$ \\
\hline \multirow[t]{4}{*}{ Euterpe edulis } & Davisella palmea & FOL & Brasil & Gondim Jr. (2000) \\
\hline & Glabrisceles euterpis & BT & Brasil & $\begin{array}{l}\text { Navia \& } \\
\text { Flechtmann (2002) }\end{array}$ \\
\hline & Notostrix exigua & FOL & Brasil & Flechtmann (1998) \\
\hline & Retracrus johnstoni & FOL & Brasil & Gondim Jr. (2000) \\
\hline Euterpe oleracea & Retracrus johnstoni & FOL & Brasil & Capítulo 3 \\
\hline Euterpe precatoria & Retracrus johnstoni & FOL & Brasil & Capítulo 3 \\
\hline \multirow[t]{2}{*}{ Euterpe sp. } & Notostrix exigua & FOL & Brasil & Gondim Jr. (2000) \\
\hline & Retracrus johnstoni & FOL & Brasil & Gondim Jr. (2000) \\
\hline Geonoma brevispatha & Acathrix lobata & $\mathrm{BT}$ & Brasil & $\begin{array}{l}\text { Navia \& } \\
\text { Flechtmann (2002) }\end{array}$ \\
\hline \multirow[t]{2}{*}{ Geonoma gamiovora } & Nasuchus pindobates & FOL & Brasil & $\begin{array}{l}\text { Navia \& } \\
\text { Flechtmann (2002) }\end{array}$ \\
\hline & Retracrus johnstoni & FOL & Brasil & Gondim Jr. (2000) \\
\hline Geonoma pohliana & Retracrus johnstoni & FOL & Brasil & Gondim Jr. (2000) \\
\hline \multirow[t]{3}{*}{ Geonoma schottiana } & Acathrix lobata & $\mathrm{BT}$ & Brasil & $\begin{array}{l}\text { Navia \& } \\
\text { Flechtmann (2002) }\end{array}$ \\
\hline & knorella geonomae & FOL & Brasil & $\begin{array}{l}\text { Gondim Jr. et al. } \\
\text { (2000) }\end{array}$ \\
\hline & Retracrus johnstoni & FOL & Brasil & Gondim Jr. (2000) \\
\hline Geonoma sp. & Acathrix lobata & FOL & Brasil & $\begin{array}{l}\text { Navia \& } \\
\text { Flechtmann (2002) }\end{array}$ \\
\hline Geonoma sp. & Schizacea geonomae & FOL & Brasil & $\begin{array}{l}\text { Navia \& } \\
\text { Flechtmann (2002) }\end{array}$ \\
\hline Livistona chinensis & $\begin{array}{l}\text { Calepitrimerus } \\
\text { livistonae }\end{array}$ & ? & China & Wei \& Feng (2002) \\
\hline \multirow[t]{2}{*}{ Lytocaryum hoehnei } & Notostrix trifida & FOL & Brasil & $\begin{array}{l}\text { Navia \& } \\
\text { Flechtmann (2003) }\end{array}$ \\
\hline & Propilus pellitus & FOL & Brasil & $\begin{array}{l}\text { Navia \& } \\
\text { Flechtmann (2002) }\end{array}$ \\
\hline
\end{tabular}


Tabela 1. Ácaros Eriophyoidea em palmeiras no mundo. Hospedeiros, espécies associadas, órgãos infestados (FOL- folhas; BT - brotos terminais; FRU- frutos), países de ocorrência e referências

\begin{tabular}{|c|c|c|c|c|}
\hline Hospedeiro & Espécie & Órgão & País & Referência \\
\hline $\begin{array}{l}\text { Lytocaryum } \\
\text { weddellianum }\end{array}$ & Aceria guerreronis & $\mathrm{BT}$ & Brasil & Flechtmann (1994) \\
\hline Mauritia flexuosa & Retracrus johnstoni & FOL & Brasil & Capítulo 3 \\
\hline Phoenix canariensis & Tumescoptes phoenixi & FOL & $\begin{array}{l}\text { África do } \\
\text { Sul }\end{array}$ & Meyer (1992) \\
\hline \multirow[t]{3}{*}{ Phoenix dactylifera } & Mackiella phoenicis & $\mathrm{BT}$ & EUA & Keifer (1939b) \\
\hline & Mackiella phoenicis & $?$ & Iraque & $\begin{array}{l}\text { Mohamed \& El- } \\
\text { Haidari (1968) }\end{array}$ \\
\hline & $\begin{array}{l}\text { Tumescoptes } \\
\text { trachycarpi }\end{array}$ & ? & Iraque & $\begin{array}{l}\text { Mohamed \& El- } \\
\text { Haidari (1968) }\end{array}$ \\
\hline Phoenix reclinata & Tumescoptes dicrus & FOL & $\begin{array}{l}\text { África do } \\
\text { Sul }\end{array}$ & Meyer (1992) \\
\hline Roystonea elata & Acritonotus denmarki & FOL & EUA & Keifer (1962a) \\
\hline Roystonea sp. & Diptacus borinquensis & FOL & Porto Rico & Cromroy (1958) \\
\hline Sabal sp. & Notostrix vazquezae & FOL & México & $\begin{array}{l}\text { Navia \& } \\
\text { Flechtmann (2003) }\end{array}$ \\
\hline Scheelea sp. & Retracrus johnstoni & FOL & Brasil & Capítulo 3 \\
\hline Syagrus cocoides & Aceria gymnoscuta & FRU & Brasil & $\begin{array}{l}\text { Navia \& } \\
\text { Flechtmann (2002) }\end{array}$ \\
\hline Syagrus flexuosa & Aceria gymnoscuta & FOL & Brasil & $\begin{array}{l}\text { Navia \& } \\
\text { Flechtmann (2002) }\end{array}$ \\
\hline Syagrus microphylla & Notostrix butiae & FOL & Brasil & Capítulo 3 \\
\hline Syagrus oleracea & Notostrix acuminata & FOL & Brasil & $\begin{array}{l}\text { Navia \& } \\
\text { Flechtmann (2003) }\end{array}$ \\
\hline Syagrus quinquefaria & Notostrix butiae & FOL & Brasil & Capítulo 3 \\
\hline \multirow[t]{9}{*}{ Syagrus romanzoffiana } & Aceria guerreronis & $\mathrm{BT}$ & EUA & $\begin{array}{l}\text { Ansaloni \& Perring } \\
\text { (2002) }\end{array}$ \\
\hline & Aceria translinea & $\mathrm{BT}$ & Brasil & $\begin{array}{l}\text { Navia \& } \\
\text { Flechtmann (2002) }\end{array}$ \\
\hline & Amrineus cocofolius & FRU & Brasil & Capítulo 3 \\
\hline & Davisella palmea & FOL & Brasil & Flechtmann (1998) \\
\hline & Notostrix attenuata & FOL & Brasil & Gondim Jr. (2000) \\
\hline & Notostrix jamaicae & FOL & Brasil & $\begin{array}{l}\text { Santana \& } \\
\text { Flechtmann (1998) }\end{array}$ \\
\hline & Propilus spinosus & FOL & Brasil & Gondim Jr. (2000) \\
\hline & Propilus syagris & FOL & Brasil & Gondim Jr. (2000) \\
\hline & Retracrus johnstoni & FOL & Brasil & $\begin{array}{l}\text { Santana \& } \\
\text { Flechtmann (1998) }\end{array}$ \\
\hline Trachycarpus fortunei & $\begin{array}{l}\text { Tumescoptes } \\
\text { trachycarpi }\end{array}$ & FOL & China & $\begin{array}{l}\text { Keifer (1939a); } \\
\text { Kuang (1991) }\end{array}$ \\
\hline
\end{tabular}




\subsection{Conclusões}

* Até o momento são relatadas 57 espécies, pertencentes a 30 gêneros de Eriophyoidea associadas a 50 espécies e 24 gêneros de palmeiras, por todo o mundo. Dentre estas espécies de Eriophyoidea, 4 pertencem a Diptilomiopidae, 42 a Eriophyidae, e 9 a Phytoptideae. Na Europa são conhecidas 4 espécies de Eriophyoidea em palmeiras; na África, 6 espécies; na Ásia e Oceania, 14 espécies e nas Américas, 35 espécies.

* Cerca de 1/3 das espécies de Eriophyoidea associadas às palmeiras são relatadas de hospedeiros de 2 ou mais gêneros distintos. 


\section{O ÁCARO DO COQUEIRO, ACERIA GUERRERONIS KEIFER (ACARI: ERIOPHYIDAE) - FILOGEOGRAFIA BASEADA EM SEQÜÊNCIAS DE DNA RIBOSSOMAL (ITS) E MITOCONDRIAL (16S e CO-I)}

\section{Resumo}

Neste trabalho foram realizadas análises filogeográficas de 29 populações do ácaro do coqueiro, Aceria guerreronis Keifer, de áreas onde este tem sido relatado na América, África e Ásia. Neste estudo, buscaram-se indicações sobre a origem, trajetórias de disseminação e fontes de recentes introduções deste eriofiídeo através da determinação de seus padrões de diversidade genética, visando a orientar estratégias para seu controle. Foram utilizados três marcadores moleculares independentes: a região do genoma nuclear "Internal Transcribed Spacer" (ITS) do RNA ribossômico, e dois fragmentos do mtDNA: o segmento $16 \mathrm{~S}$ e a região codante para a citocromo oxidase 1 (CO-I). Os índices de diversidade das sequiências foram estimados e a estrutura das populações foi determinada através da Análise de Variância Molecular (AMOVA). As análises filogenéticas foram realizadas utilizando-se probabilidade máxima (ML), parcimônia máxima (MP) e inferência Bayesiana. O alinhamento da região ITS apresentou 987 posições; o da região 16S, 404 posições e o da região CO-I, 494 posições. Apenas as seqüências das regiões ITS e 16S foram submetidas às análises de diversidade, pois foram obtidas seqüências CO-I para poucas populações. Foram encontradas 46 seqüências diferentes da região ITS entre as 52 seqüências (23 da América, 19 da Ásia e 5 da África) obtidas de 23 amostras. A diversidade mais alta para a região ITS foi detectada entre as populações do Brasil (1,90\%) quando comparada à diversidade das demais localidades da América $(0,54 \%)$, da África $(0,70 \%)$ e da Ásia 
(0,49\%). Entre as seqüências obtidas da região 16S, foram detectados 7 haplótipos, dos quais 6 são de populações americanas. Todas as populações dos outros continentes apresentaram um mesmo haplótipo. A diversidade mais alta foi encontrada entre populações do Brasil, onde todos os haplótipos americanos foram representados. AMOVA aplicada a seqüências de duas diferentes áreas (Brasil e demais países da América) mostrou que a diversidade total apresentada dentro de cada uma das áreas foi maior que a obtida entre estas áreas. As árvores filogenéticas obtidas considerando as seqüências das três regiões do genoma, utilizando ML, MP e inferências Bayesianas foram similares e nenhuma diferença topológica foi encontrada. As filogenias ITS, 16S e CO-I foram congruentes e apresentaram, em aspectos gerais, a mesma topologia. Observou-se a formação de dois clados principais: um americano e outro afro-asiático. Estes clados refletiram uma estrutura geográfica relacionada a um restrito fluxo gênico e isolamento entre as populações que os compuseram. Os resultados das análises filogeográficas foram concordantes com aqueles das análises morfométricas e são consistentes com o possível histórico de disseminação e invasões de A. guerreronis, com a hipótese de que o coqueiro (Cocos nucifera L.) não seja o hospedeiro original deste eriofí́deo e com os meios de dispersão considerados possíveis para o ácaro. Os resultados sugerem que: A. guerreronis apresenta uma origem americana; que a introdução na África ocorreu em um único evento de colonização e a partir de um número reduzido de indivíduos; e que, possivelmente, a introdução na Ásia se deu a partir de populações africanas ou de uma população fonte comum a estas. Os resultados deste trabalho foram discutidos em relação ao planejamento da prospecção para inimigos naturais visando à implementação de um programa de controle biológico clássico e à adoção de medidas quarentenárias para evitar uma maior disseminação deste ácaropraga.

THE COCONUT MITE, Aceria guerreronis KEIFER (ACARI: ERIOPHYIDAE) FILOGEOGRAPHY BASED ON MITOCONDRIAL (16S AND CO-I) AND RIBOSOMIC (ITS) DNA SEQUENCES 


\section{Summary}

Phylogegeographic analyses of 29 Aceria guerreronis Keifer populations of different countries, including the main coconut production areas of America, Africa and Asia were conducted. The objective of the work was to help in the determination of the place of origin, dissemination trajectories and sources of recent invasions of this eriophyid, through the determination of diversity patterns of the mite in its area of distribution, to orient the proposition of strategies for its control. Three independent molecular markers were used: the nuclear genomic region "Internal Transcribed Spacer" (ITS) of rRNA and two mtDNA fragments: 16S segment and the coding region for cytochrome oxidase 1 (CO-I). Indexes of diversity of the sequences were estimated and the population structures were determined through Molecular Variance Analysis (AMOVA). Phylogenetic analyses were conducted using maximum likelihood (ML), maximum parsimony (MP) and Bayesian interference. The alignment of ITS region had 987 positions; 16S region, 404 and CO-I region, 494 positions. Forty-six different sequences in ITS region between the 52 obtained sequences of 22 samples (23 from the Americas, 19 from Asia and 5 from Africa) were found. The higher diversity for this region was detected between the Brazilian populations (1.90\%) when compared with the diversity of the other sites in America (0.54\%), Africa (0.70\%) and Asia (0.49\%). Between the sequences obtained in 16S region, 7 different haplotypes were detected, six of which of the American populations. All populations from other continents belonged to the same haplotype. The highest diversity was observed between the Brazilian populations, which had representatives of all American haplotypes. AMOVA applied to sequences of two different areas (Brazilian and to non Brazilian American countries) showed that the total diversity presented inside these areas was higher than between these areas. Phylogenetic trees constructed from the sequences of the three genomic regions, using MP, ML and Bayesian inferences were similar and no topological differences were observed. ITS, 16S and CO-I phylogenies were congruent and had, in general aspects, the same topology. Two main clades were distinguished in the cladogram, an American and an Afro-Asiatic. Those reflected a geographic structure related to the genetic isolation between those populations. Analyses of ITS, 16S and CO- 
I sequences revealed only partial geographic structure, as some geographically close Brazilian populations were rather distinct, whereas populations from different continents (Africa and Asia) were very similar. Results of the phylogeographic analyses agreed with those of morphometric analyses and are consistent with the possible history of the dissemination and spread of A. guerreronis, with the hypothesis that coconut is not the original host of this mite and with the dispersion means considered possible for it. They suggest that $A$. guerreronis is native to the Americas, that the introduction to Africa (where the presence of the mite was reported before from Asia) represented a single event involving a reduced number of individuals and that, possibly, the introduction to Asia occurred with mites from Africa or had the same source in America as the African populations. The results of this work were discussed in relation to the planning for the search for natural enemies for the implementation of a classical biological control program and the adoption of quarantine measures to avoid a wider dissemination of this mite pest.

\subsection{Introdução}

O coqueiro, Cocos nucifera L., é uma das culturas de maior valor nos trópicos úmidos e uma das mais importantes a nível mundial (Vietmeyer, 1986). O coqueiro está presente na vida diária de comunidades locais em áreas tropicais e é referido como “árvore da vida” na Ásia, onde é extensamente cultivado. As principais regiões produtoras de coco concentram-se na Ásia (Filipinas, India, Indonésia, Papua Nova Guiné, Sri Lanka) e nas Ilhas do Pacífico, mas também é bastante importante nas áreas litorâneas das Américas e da África (Persley, 1992).

Invasões biológicas constituem uma das principais ameaças para a biodiversidade de ecossistemas naturais. Bioinvasões envolvendo pragas exóticas tem representado sérios problemas para a agricultura mundial. A intensificação do comércio e do transporte no último século tem aumentado dramaticamente a disseminação destas (Wittenberg \& Cock, 2001). 
O ácaro do coqueiro, Aceria guerreronis Keifer, 1965 tem sido disseminado e se estabelecido rapidamente nas principais áreas produtoras desta cultura, sendo considerado uma de suas pragas-chave em diferentes partes do mundo. Suas populações desenvolvem-se na zona meristemática dos frutos e a alimentação dos mesmos resulta em crescimento desigual, distorção, atrofia e/ou queda prematura dos frutos. Além disso, A. guerreronis tem sido relatada infestando brotos terminais e mesmo matando plantas jovens de coqueiros em Pernambuco, Brasil (Aquino \& Arruda, 1967); da palmeirinhade-Petrópolis, Lytocaryum weddellianum (H. Wendl.) Tol., em São Paulo, Brasil (Flechtmann, 1989); e de jerivá, Syagrus romanzoffiana (Cham.) Glass., na Califórnia, EUA (Ansaloni \& Perring, 2002).

A origem do ácaro do coqueiro ainda é desconhecida. A espécie foi descrita a partir de espécimes de Guerrero, México em 1965 (Keifer, 1965). Entretanto, há informações de que este ácaro já estivesse presente em algumas outras regiões do México, no Brasil e na Colômbia, na época em que foi descrito (Ortega et al., 1965; Robbs \& Peracchi, 1965; Zuluaga \& Sánchez, 1971). Logo após sua descrição, o ácaro foi relatado nas Ilhas do Golfo de Guiné (São Tomé e Príncipe), em 1966, e na costa Oeste da África, em 1967 (Cabral \& Carmona, 1969; Mariau, 1969). No leste da África, na Tanzânia, o ácaro foi relatado na década de 1980 (Seguni, 2000). Este ácaro só foi reportado na Ásia, na Índia e em Sri Lanka, no final da década de 1990 (Sathiamma et al., 1998; Fernando et al., 2000).

O principal hospedeiro de A. guerreronis, o coqueiro, é atualmente aceito como sendo originário da região Indo-Pacífica, mais especificamente da região que se estende do extremo sudeste asiático até as Ilhas do Pacífico (Papouasie) (Persley, 1992; Lebrun et al., 1998ab), mas a presença do ácaro do coqueiro ainda não foi relatada nesta região.

Para entender os processos de bioinvasão de uma dada espécie praga e definir estratégias de controle, são importantes informações sobre sua estrutura geográfica, sua origem e suas fontes de invasão para diferentes locais (Carey, 1991; Davies et al., 1999).

As maiores perspectivas para o controle de A. guerreronis parecem se referir à utilização de agentes de controle biológico (Moraes \& Zacarias, 2002). O controle 
químico do ácaro parece ser pouco viável, pois para que os acaricidas sejam efetivos, são necessárias aplicações periódicas. Na maioria das áreas produtoras, a cultura do coco é tipicamente realizada por pequenos produtores, que não dispõem de recursos para a compra de pesticidas (Moore \& Howard, 1996; Muthiah \& Bhaskaran, 2000; Ramaraju et al., 2002). O conhecimento da origem do ácaro do coqueiro é crucial para determinar as áreas prioritárias a serem consideradas na busca de inimigos naturais efetivos (Moraes \& Zacarias, 2002).

Além disto, A. guerreronis continua representando uma ameaça quarentenária para outros países na Região Indo-Pacífica, além da India e Sri Lanka. Informações sobre a fonte de recentes invasões em novas áreas podem guiar a adoção de medidas quarentenátrias. Esforços para interceptação de novas introduções deste ácaro-praga devem ser concentrados nas fontes mais prováveis de infestação, que podem ser mais facilmente determinadas se os meios de disseminação do ácaro no mundo fossem identificados.

Informações genéticas às vezes constituem os melhores, ou únicos, dados para estudos de aspectos demográficos, como migração ou disseminação de populações (Slatkin, 1987). Recentemente, marcadores moleculares têm sido utilizados em estudos de processos de bioinvasões, fornecendo informações sobre a origem das espécies e fontes de infestação (Villablanca et al., 1998; Davies et al., 1999; Bonizzoni et al., 2001; Birungi \& Munstermann, 2002).

A variação de seqüências de DNA nuclear e mitochondrial (mtDNA) de uma espécie invasora pode ser utilizada para uma melhor compreensão da estrutura das populações introduzidas. Diferentes marcadores moleculares podem elucidar questões diferentes de acordo com sua velocidade e modo de evolução (Meixner et al., 2002). A análise de variações do DNA mitocondrial é mais adequada para estudos de invasões quando as populações invasoras são grandes ou crescem rapidamente. Isto ocorre porque o mtDNA é sujeito a forte deriva genética, devido ao seu modo de herança maternal (Neigel \& Avise, 1986). A análise do mtDNA também é recomendada no estudo genético de processos de invasões recentes (Davies et al., 1999). A variação no DNA nuclear é retida por longos períodos de tempo, mas a identificação de seqüências de 
DNA variáveis no genoma nuclear pode ser difícil (Villablanca et al., 1998). A informação fornecida por marcadores de diferentes compartimentos do genoma, isto é, nucleares e citoplásmicos, podem mostrar padrões filogenéticos discordantes (Navajas et al., 1998a; Navajas \& Boursot, 2003; Toda et al., 2000). É necessário interpretar os resultados à luz do modo de evolução molecular dos diferentes tipos de seqüências.

As populações colonizadoras das espécies invasoras são normalmente representadas por poucos indivíduos que correspondem a seç̧ões restritas da população de origem. As conseqüências genéticas de tais eventos de colonização incluem "efeito fundador" e "gargalo genético" (genetic bottlenecks) (Lande \& Barrowclough, 1987; Nei et. al., 1975). Estes fenômenos fazem com que as populações invasoras apresentem limitada variação genética nas áreas então colonizadas e com que possam ocorrer diferenças de haplótipos ${ }^{1}$ fixados em diferentes regiões geográficas (Gasparich et al., 1997). Por outro lado, grande variabilidade genética em populações invasoras indica que houve um grande número de indivíduos fundadores ou que ocorreram múltiplas invasões (Stepien et al., 2002). Entretanto, embora uma grande variabilidade genética seja freqüentemente tida como necessária à capacidade de adaptação dos indivíduos a novos ambientes, esta característica não é a única relacionada ao potencial de colonização das espécies invasoras (Roderick and Navajas, 2003).

Neste trabalho foram realizadas análises filogeográficas de populações de $A$. guerreronis de diferentes áreas onde este ácaro tem sido relatado, incluindo as principais áreas de produção de coco da América, África e Região Indo-Pacífica, na Ásia. Foram utilizados três marcadores independentes: a região do genoma nuclear "Internal Transcribed Spacer” (ITS1-5,8S-ITS2) do RNA ribossômico (rRNA) e dois fragmentos do mtDNA, a região codante para a citocromo oxidade 1 (CO-I) e o segmento $16 \mathrm{~S}$. Neste estudo buscaram-se indicações sobre a origem, trajetórias de disseminação/invasão e fontes de recentes introduções de A. guerreronis. Este estudo

\footnotetext{
${ }^{1}$ haplótipo - combinação de polimorfismos do DNA (sequências de nucleotídeos) transmitidos em conjunto para os descendentes; constituição genética de um indivíduo com relação a um dos membros de um par de genes alélicos.
} 
também foi motivado pela necessidade de estabelecer padrões de diversidade da praga em sua área de distribuição, visando a orientar estratégias para seu controle.

\subsection{Revisão de Literatura}

\subsubsection{Genética molecular em estudos filogenéticos e filogeográficos}

Os estudos de sistemática filogenética têm como objetivo reconstruir a história evolutiva dos grupos de organismos (Amorim, 1994).

Avanços recentes nas teorias da genética de populações, especialmente com a teoria de coalescência, associada ao rápido avanço das técnicas moleculares, tem permitido o acesso a detalhada informação filogenética a nível populacional, nas quais diferentes haplótipos representam unidades taxonômicas operacionais (OTU) (Crandall \& Templeton, 1996). A teoria de coalescência busca responder à seguinte questão sobre uma amostra de seqüências moleculares homólogas de uma população: qual é a distribuição esperada do número de diferenças de pareamentos entre as seqüências, assumindo que as mesmas tem evoluído com neutralidade em uma população que tem sempre o mesmo tamanho? A abordagem de coalescência baseia-se nas seguintes idéias: 1) esta reconhece que as moléculas em uma amostra são, no presente, relacionadas umas às outras, de modo que poderiam, em princípio, ser representadas como a árvore genealógica de uma família ou de uma série de genes; 2) esta faz uma modelagem do processo mutacional que ocorre ao longo das linhagens desta árvore que irão gerar a variação observada das seqüências. Assim, considerando que estão ocorrendo mutações, assume-se que as seqüências mais relacionadas tendem a ser mais similares. Por razões de ordem prática, a teoria da coalescência adota uma perspectiva temporal retrospectiva, na determinação da árvore genética. Assim, ao invés de considerar que a árvore está crescendo, com bifurcações ocorrendo nos nodos, a árvore é modelada como se estivessem ocorrendo coalescências das linhagens nos nodos de bifurcação (Harvey \& Nee, 1996). A revolução na tecnologia de sequenciamento de genes tem permitido a construção de genealogias ou filogenias mais acuradas, as quais podem ajudar no 
entendimento dos processos biológicos que vem ocorrendo em diferentes níveis de hierarquia dos organismos (Harvey \& Nee, 1996). Informações sobre seqüências de DNA podem ser utilizadas como ferramentas importantes na reconstrução das relações evolutivas entre organismos (Weekers et al., 2001).

Os primeiros trabalhos em que foram utilizadas abordagens de filogenética molecular em estudos de genética de populações, especialmente relacionados a padrões biogeográficos, foram publicados no final da década de 1980 (Avise et al., 1987; Avise, 1989). Estes trabalhos exploram qualitativamente a relação entre divergência de linhagens e a extensão da partição geográfica entre haplótipos (Crandall \& Templeton, 1996).

De acordo com Avise (1989), levantamentos sobre a diversidade de haplótipos no DNA mitocondrial (mtDNA) forneceram os primeiros dados empíricos para a estimativa de árvores de genes (gene rree $^{2}$ ) em uma escala microevolucionária intraespecífica. As relações entre filogenia e distribuição geográfica constituem os padrões filogeográficos para uma determina espécie. Árvores filogeográficas podem ser interpretadas em termos de demografia histórica considerando os modelos de distribuição de linhagens de genes.

A estrutura geográfica de uma determinada espécie trata da distribuição e abundância de genótipos entre e dentro de populações (Roderick, 1996). Esta definição inclui dois componentes distintos, mas relacionados: a estrutura demográfica e a estrutura genética da espécie (Slatkin ${ }^{3}$ citado por Roderick, 1996). A estrutura demográfica trata dos processos que influenciam o número e distribuição das classes fenotípicas dos indivíduos. A estrutura genética de uma espécie pode ser descrita como a distribuição da variação genética e o resultado de migração, seleção, mutação, deriva genética e outros fatores relacionados a estes processos, para uma dada espécie (Roderick, 1996). Devido ao fato da demografia estar relacionada a estes processos

\footnotetext{
${ }^{2}$ Gene tree - filogenia de um gene particular ou de um segmento de DNA. Podem ser estimadas a partir de seqüências de nucleotídeos, aminoácidos, mapas de restrição ou qualquer outro procedimento em que alelos possam ser considerados OTUs (Avise, 1989).

${ }^{3}$ SLATKIN, M. Gene flow and population structure. In: REAL, L.A. (Org.). Ecological genetics. Princeton: Princeton University Press, 1994. p. 3-17.
} 
genéticos, estrutura genética e demográfica são, necessariamente, interligadas. Por esta razão, a estrutura genética de uma espécie pode ser utilizada para inferir sobre os processos e sobre o histórico demográfico de uma espécie (Roderick, 1996).

A estrutura geográfica de uma espécie pode ser inferida indiretamente através de dados genéticos. Estes dados genéticos podem ser analisados de duas maneiras distintas: 1) tradicionalmente, de modo que as populações são tratadas como unidades genéticas e são estimadas medidas de similaridade entre as populações; 2) através de estudos filogeográficos, nos quais as relações entre os genótipos (filogenias de alelos ou haplótipos) de uma ou mais populações podem ser examinadas em relação à sua localização geográfica (Avise et al., 1987; Roderick, 1996). Neste segundo caso, analisa-se a variação nas seqüências de DNA para estabelecer relações entre os haplótipos do mesmo loco (Roderick, 1996).

\subsubsection{Marcadores moleculares em estudos de filogenética molecular}

Os marcadores mais comumente utilizados em sistemática molecular são o mtDNA e o rDNA, os quais diferem consideravelmente em sua organização genômica e no modo de transmissão. Devido a isto, é importante considerar como as propriedades contrastantes destes marcadores podem afetar suas habilidades na construção de filogenias (Navajas \& Boursot, 2003) e que, estudos filogenéticos, baseados em resultados de um único marcador molecular, podem levar a resultados enganosos (Brower et al., 1996; Ross et al., 1999; Navajas \& Boursot, 2003).

As seqüências de DNA ribossomal (rDNA) são comumente utilizadas para o estudo das relações filogenéticas, da variabilidade genética, e de divergências dentro e entre espécies por apresentarem propriedades muito apropriadas para esta finalidade: taxas diferenciais de evolução entre diferentes regiões e genes repetidos (Gebri ${ }^{4}$ citado por Weekers et al., 2001). Nos organismos eucariontes, o rDNA apresenta unidades transcricionais repetitivas (tandem), as quais são separadas por espaços intergênicos. Dentro de cada unidade transcricional, o “Internal Transcribed Spacer 1” (ITS1) separa a

\footnotetext{
${ }^{4}$ GEBRI, S. A. Evolution of ribosomal DNA. In MACINTYRE, R. J. (Org.). Molecular evolutionary genetics. New York: Plenum, 1985. p.419-517.
} 
pequena subunidade $18 \mathrm{~S}$ da 5,8S, enquanto que o "Internal Transcribed Spacer 2" (ITS2) separa a unidade 5,8S da grande subunidade 28S. As regiões codantes apresentam pequena divergência entre espécies próximas, entretanto as regiões ITS possam apresentar maior variabilidade. Mutações ocorrem em taxas relativamente rápidas nestas regiões ITS (Weekers et al., 2001). Assim, as regiões codantes e os espaçadores diferem largamente em sua taxa de evolução, de modo que estas regiões do rDNA apresentam potencial para revelar relações filogenéticas desde o nível de filos até o nível populacional, sendo consideradas muito versáteis para análises filogenéticas (Hillis \& Dixon, 1991).

Uma limitação primária da região ITS em análises filogenéticas e no estudo de populações é a existência de polimorfismos entre unidades repetidas, que pode causar variação dentro de um mesmo indivíduo. Como exemplo, estudos filogenéticos sobre o besouro Cicindela dorsalis Say baseados na região ITS1 mostraram que a variação dentro dos indivíduos era quase tão alta quanto a variação em toda uma linhagem. O padrão de variação das seqüências sugeriu que existiam duas formas de ITS1, as quais eram mantidas em cromossomos diferentes (Vogler \& DeSalle, 1994). Entretanto, esta tendência para diversificação é "reparada” por um processo conhecido como “direção molecular”, o qual resulta na homogeneização das repetições individuais permitindo a produção de seqüências uniformes em todas as repetições de uma dada espécie (Vogler \& DeSalle, 1994; Polanco et al., 1998). Por isto, a utilidade da região ITS para estudos populacionais deve ser analisada para cada espécie (Roderick, 1996). Até o momento, em ácaros fitófagos, não têm surgido problemas associados à diversidade intraindividual e este marcador tem sido amplamente utilizado (Navajas \& Fenton, 2000).

Seqüências de mtDNA representam uma ferramenta poderosa para estudos evolucionários e tem sido utilizadas em estudos de estrutura de populações, fluxo gênico, hibridização, biogeografia e relações filogenéticas (Avise et al., 1987). A maior parte do mtDNA de animais superiores apresenta uma série de características que o torna marcadores ideais em estudos filogenéticos: 1) apresenta uma estrutura genética simples, sem a presença de regiões repetitivas, elementos transponíveis, pseudogenes ou introns; 2) geralmente evolui rapidamente, pois apresenta uma taxa de divergência de 
seqüências relativamente rápida. As variações se apresentam, primariamente, como substituições de bases; 3) a herança é maternal, o modo de transmissão ao longo das gerações é efetivamente haplóide, não há recombinação; seus genes representam um loco genético único; 4) a ordem e composição dos genes é conservada; 5) as sequências são curtas em comparação às do genoma nuclear (Avise et al., 1987; Hoy , 1994; Roderick, 1996).

A taxa de evolução dos genes mitocondriais varia entre linhagens, entre genes e mesmo dentro dos genes. No mtDNA há regiões que divergem rapidamente, enquanto que outras regiões são altamente conservadas, podendo diferentes regiões ser utilizadas em diferentes níveis taxonômicos. Em insetos, observa-se que a taxa de evolução dos genes mitocondriais é, em média, de 1-2 vezes mais rápida que a dos genes nucleares (Hoy, 1994).

As filogenias não devem ser construídas utilizando-se um único marcador, mas deve-se comparar os resultados de marcadores com propriedades distintas para evitar conclusões errôneas. Por exemplo, análises filogenéticas utilizando seqüências das regiões CO-I do mtDNA e ITS2 do rDNA de duas espécies do gênero Tetranychus, $T$. urticae e $T$. turkestani Ugarov \& Nikolskii, mostraram que estas espécies são polifiléticas para o mtDNA, mas monofiléticas para o rDNA. A diversidade de nucleotídeos foi de 3-4\% para a região CO-I, mas menor que 0,5\% para a região ITS2. Os resultados indicam que, apesar da transmissão biparental e multiplicidade de cópias no genoma, o rDNA apresenta menor tamanho populacional efetivo que o mtDNA nestas espécies (Navajas \& Boursot, 2003). Os autores sugerem que a conjunção do "reparo evolutivo" e/ou conversão de genes nas regiões do rDNA, a haplodiploidia e a proporção sexual superior de fêmeas podem influenciar esta aparente contradição ao padrão esperado. Também, a filogenia das espécies japonesas do gênero Panonychus, baseada em seqüências da região CO-I do mtDNA, foram discordantes daquelas obtidas utilizando-se regiões do rDNA (Toda et al., 2000).

De um modo geral, as variações no mtDNA em estudos a nível populacional parecem ser mais úteis que as variações nos genes ribossomais. Dentro de uma população, a frequência de um único haplótipo de mtDNA pode flutuar mais 
rapidamente que as frequências dos alelos de DNA nucleares e, por isto, o mtDNA seria mais sensível ao "efeito fundador" e a tamanhos reduzidos das populações invasoras, que o DNA nuclear. A perda ou aquisição de um haplótipo é importante em pequenas populações e a migração de poucos indivíduos entre populações seria suficiente para fixar uma linhagem de mtDNA nestas (Roderick, 1996).

\subsubsection{Estudos filogeográficos e bioinvasões}

Estudos filogeográficos podem ser realizados para verificar a estrutura geográfica de uma espécie ou para estimar fluxo gênico entre populações. A história ou genealogia dos haplótipos pode ser inferida a partir das variações das seqüências, sugerindo-se então a origem dos eventos de colonização ou a direção do fluxo gênico. A filogeografia também pode ser utilizada para testar a monofilia das populações, para determinar se a invasão ocorreu em um ou mais eventos de colonização. Outras importantes questões relacionadas aos processos de bioinvasão tratam da origem dos colonizadores e da velocidade de disseminação dos mesmos (Roderick, 1996).

Diversos estudos filogeográficos focalizando processos de bioinvasão de insetos de importância agrícola ou médica tem sido realizados.

Estudos genéticos sobre as introduções da mosca-do-Mediterrâneo, Ceratitis capitata (Wiedemann), na Califórnia, EUA, tem sido realizados utilizando variações de seqüências de introns nucleares múltiplos, de mtDNA e de microsatélites (Villablanca et al., 1998; Davies et al., 1999; Bonizzoni et al., 2001; Meixner et al., 2002). Os resultados de Meixner et al. (2002) indicaram que ocorreram de seis a sete introduções independentes desta mosca-das-frutas na Califórnia de 1992 a 1999 e sugeriram as origens destas colonizações.

Origem geográfica e fluxo gênico de populações de Apis mellifera L. tem sido estudados utilizando-se genética molecular. Análises de seqüências de mtDNA de populações de A. mellifera nos EUA dão evidências de que ocorreu uma introdução das abelhas africanizadas naquele país no século XIX (Schiff \& Sheppard, 1993). Sheppard et al. (1991) realizaram estudos sobre o fluxo gênico entre populações de A. mellifera de origem africana e européia na Argentina. 
Um mosquito vetor da dengue, Aedes albopictus (Skuse), colonizou os EUA e o Brasil cerca de 15 anos atrás. A origem geográfica das introduções e as mudanças na estrutura das populações tem sido estudadas através da comparação de seqüências de mtDNA (Kambhampat et al., 1990; Kambhampati, 1991; Birungi \& Munstermann, 2002).

\subsubsection{Marcadores moleculares em estudos com ácaros plantícolas}

Técnicas moleculares representam ferramentas úteis a acarólogos sistematas, auxiliando não apenas na identificação de espécies muito relacionadas, mas também na distinção de categorias sub-específicas e na caracterização de biótipos. Pesquisadores envolvidos em defesa fitossanitária, controle biológico, parasitologia, biologia de populações, ecologia molecular e diversas outras áreas vêm se beneficiando com estas novas oportunidades (Mozes-Koch \& Gerson, 1998).

A utilização de marcadores moleculares em estudos com ácaros têm contribuído sobremaneira para o aumento do conhecimento sobre a sistemática, a filogenética e a estrutura das populações. Estudos utilizando técnicas de genética molecular focalizando ácaros plantícolas de importância agrícola têm envolvido principalmente espécies das famílias Tetranychidae, Eriophyidae e Phytoseiidae (Navajas \& Fenton, 2000; Cruickshank, 2002).

Revisões sobre a utilização de marcadores moleculares em estudos de sistemática e filogenética de ácaros, nas quais foram compiladas informações sobre os métodos utilizados nos estudos, os principais resultados e as perspectivas foram publicados recentemente em Navajas \& Fenton (2000) e Cruickshank (2002). Como em outros grupos de organismos, os marcadores moleculares mais comumente utilizados em estudos com ácaros são o mtDNA e o rDNA. Alguns estudos utilizando RAPD (random amplified polymorphism DNA) também têm sido realizados.

Trabalhos em que foram utilizados marcadores moleculares em estudos com ácaros começaram a ser publicados entre 1990 e 2000. Kaliszewski et al. (1992) utilizaram PCR (“Polymerase Chain Reaction”) para sequenciar o DNA de 17 espécies de ácaros, pertencentes a diversos grupos. Para comparação do genoma destas 17 
espécies utilizaram um fragmento de 377pb da região 18S do rRNA nuclear e um fragmento de 500pb da região $16 \mathrm{~S}$ do rRNA mitocondrial. O DNA destes fragmentos foi sequenciado. Seus dados indicaram que PCR poderia ser utilizado para obter informação de seqüências de ácaros de várias ordens, podendo auxiliar nos estudos filogenéticos. Neste trabalho também foram detalhados métodos para extração e amplificação de DNA de ácaros.

Estudos utilizando marcadores RAPD mostraram que material genético paternal é transmitido para os filhos em cruzamentos controlados em ácaros fitoseídeos pseudoarrenótocos (Perrot-Minot \& Navajas, 1995). Esta técnica, conjuntamente com estudos de fecundidade e biometria, foi utilizada para comparar biótipos de Tetranychus sp. (Hence et al., 1998).

Estudos sobre o modo de evolução do mtDNA de 20 espécies da superfamília Tetranychoidea mostraram que as características e o modo de evolução do mtDNA nestes ácaros são similares àqueles conhecidos para os insetos, sugerindo que estes artrópodes compartilharam caracteres ancestrais (Navajas et al., 1996).

Estudos sobre a sistemática e filogenética de espécies de Tetranychoidea foram realizados utilizando seqüências da região CO-I do mtDNA e os resultados foram comparados aos da filogenia utilizando características morfológicas e biológicas (Navajas et al., 1996). A resolução de questões taxonômicas no gênero Tetranychus Dufour tem sido realizada utilizando RAPD (Dong et al., 1997) e sequenciamento de rDNA. Navajas et al. (2001) estabeleceram a sinonímia entre T. kanzawai Kishida e $T$. hydrangea Pritchard \& Baker baseados em análises de seqüências da região ITS2 e em estudos de cruzamentos. O gênero Amphytetranychus Oudemans foi reconsiderado válido como resultado de estudos comparando caracteres moleculares (ITS2 e CO-I) e morfológicos de Tetranychus viennensis Zacher (sinônimo de Amphitetranychus viennensis (Zacher, 1920)) com os de outras oito espécies de Tetranychidae (Navajas et al., 1997). Variação intraespecífica em T. kanzawai foi estudada utilizando seqüências de ITS e CO-I (Hinomoto \& Takafuji, 2001). A diferenciação genética entre populações de $T$. urticae tem sido estudada através de métodos moleculares, conjuntamente com a avaliação de parâmetros biológicos, comportamentais e morfológicos (Gotoh et al., 
1993; Hence et al., 1998; Navajas, 1998b; Tsagkarakov et al., 1999; Navajas et al., 2000). Variabilidade intraespecífica e interespecífica nos gêneros Mononychellus Wainstein e Panonychus Yokoyama de Tetranychidae tem sido estudada utilizando-se seqüências de ITS2 e CO-I (Navajas et al., 1994; Toda et al., 2000).

A estrutura genética de um ácaro tetraniquídeo invasor, Mononychellus progressivus Doreste, originário da região neotropical e, acidentalmente introduzido no leste da África na década de 1970, foi estudada utilizando-se seqüências de CO-I e de ITS2. Os resultados sugeriram que $M$. progressivus foi introduzido a partir de populações da Colômbia (Navajas et al., 1994).

Estudos moleculares, utilizando alozimas, também foram realizados para traçar a origem de um outro ácaro-praga invasor, Halotydeus destructor (Tucker) (Penthaleidae). Os autores apresentaram evidências de que sua provável área de origem é a África do Sul e que, de lá foi introduzido na Austrália (Quin, 1997).

A filogeografia e a estrutura genética de T. urticae têm sido estudadas utilizandose seqüências de CO-I do mtDNA. Os resultados mostraram o padrão geográfico genético deste ácaro ao longo de sua área de distribuição, com a caracterização de duas linhagens. Mostraram ainda que houve uma colonização antiga no Mediterrâneo e uma colonização recente nas regiões temperadas do hemisfério norte (Navajas et al., 1998a). Análises de alozimas e estudos da variação nas seqüências ITS2 de populações de $T$. urticae do Mediterrâneo, permitiram uma avaliação do papel da planta hospedeira e da distância geográfica no processo de diferenciação genética (Navajas 1998a; Navajas et al. 2000).

Trabalhos em que foram utilizados marcadores moleculares em estudos com ácaros Eriophyoidea referem-se principalmente a espécies de Cecidophyopsis Keifer. As reduzidas dimensões e a localização críptica destes ácaros em várias espécies de plantas do gênero Ribes dificultam sua identificação. Entre estas espécies, C. ribis (Westwood) é uma das pragas mais sérias de Ribes nigrum (blackcurrant). Uma série de estudos utilizando técnicas moleculares vem sendo realizada para a identificação, construção da filogenia e estudo da variabilidade intraespecífica destes ácaros. Fenton et al. (1995) relataram que alterações no número de cópias do gene ribossomal vSSRs no genoma de 
Cecidophyopsis podem ser utilizadas para separar as espécies que co-infestam Ribes spp. Este estudo demonstrou que diferentes espécies deste gênero causam galhas em gemas de distintas espécies de Ribes. Kumar et al. (1999) desenvolveram uma técnica de PCR multiplex para identificação das espécies de Cecidophyopsis associadas a plantas daquele gênero. O sequenciamento da região ITS do rDNA de seis espécies de Cecidophyopsis mostrou a exostência de diferenças inter-específicas em 17 sítios ITS, mas nenhuma variação intraespecífica. Esta ausência de variação intraespecífica sugere a existência de um processo de homogeneização intraespecífica em curso nas espécies de Cecidophyopsis. O processo possivelmente é facilitado pelo isolamento dos ácaros no interior das gemas, que dificulta a hibridização de distintas colônias; outros fatores envolvidos poderiam ser a haplo-diploidia e a arrenotoquia, que reduzem a variabilidade intra-populacional (Fenton et al., 1996, 1997). A filogenia molecular das sete espécies de Cecidophyopsis que infestam Ribes, inferidas a partir de seqüências de rDNA, foi relacionada à filogenia de suas plantas hospedeiras. A estrutura das árvores filogenéticas foi diferente, indicando que a especiação em Cecidophyopsis não acompanhou a especiação dos hospedeiros, divergindo em seus hospedeiros recentemente, enquanto que as espécies de Ribes se separaram em um período consideravelmente anterior (Fenton et al., 2000).

Muitas espécies de ácaros da família Phytoseiidae são liberadas em programas de controle biológico para suprimir populações de ácaros fitófagos. A identificação precisa dos organismos em um programa de controle biológico é de fundamental importância. A utilização de marcadores moleculares tem sido buscada e seriam especialmente úteis para separação de espécies crípticas. Edwards et al. (1997), através de RAPD-PCR, distinguiram três espécies de Typhlodromalus (T. manihoti (Moraes), T. limonicus (Garman \& McGregor) e T. tenuiscutus (McMurtry \& Moraes)), utilizando cinco de oito primers testados. As distâncias genéticas dentro das espécies $(0,072-0,186)$ foram muito mais baixas que entre as espécies $(0,407-0,656)$. A variação de seqüências da região ITS e 5,8S em seis espécies de fitoseídeos (Euseius concordis (Chant), Neoseiulus californicus (McGregor), N. fallacis (Garman), Galendromus occidentalis (Nesbitt), Phytoseiulus persimilis Athias-Henriot e Typhlodromus pyri Scheuten) foi avaliada em 
Navajas et al. (1999). A região 5,8S destes ácaros mostrou-se marcadamente conservada, a região ITS1 é curta (85-90pb) e apresentou pouca variação e a região ITS2 é mais longa (303-404) e apresentou maior variação nas seqüências. A variação intraespecífica foi avaliada em três espécies, observando-se baixo polimorfismo. Seqüências da região 12S do rRNA mitocondrial foram utilizadas para definir ensaios para identificação de seis espécies de fitoseídeos (N.fallacis, N. californicus, N. cucumeris (Oudemans), G. occidentalis, Iphiseius degenerans (Berlese) e P. persimilis) (Jeyaprakash \& Hoy, 2002). As divergências das seqüências neste loco foram muito maiores que as da região ITS.

O sistema de reprodução de pseudo-arrenotoquia em $N$. californicus, utilizando a técnica conhecida como DALP (Direct Amplification of Length Polymorphism), foi estudado isolando-se cinco locos polimórficos (Perrot-Minot et al., 2000ab). A transmissão mendeliana dos alelos e a sua co-dominância foi verificada. O padrão de transmissão dos alelos parentais, por duas gerações, foi relatado nos cinco locos, fornecendo evidências da retenção, no tecido somático dos machos, da maioria (senão de todos) dos cromossomos paternais.

\subsubsection{Métodos em análise filogenética molecular}

A construção de árvores filogenéticas atualmente faz parte da análise exploratória de seqüências moleculares. A análise comparativa de seqüências é uma ferramenta importante em genética. Estas análises comparativas são representadas sob a forma de árvores filogenéticas, que descrevem a relação evolutiva entre as seqüências. A reconstrução de seqüências ancestrais pode mostrar o tempo e a direção das mutações (Holder \& Lewis, 2003).

A estimativa de árvores filogenéticas parece ser um exercício relativamente simples ao se assumir que duas seqüências divergem de seu ancestral comum à medida que o tempo passa, sendo necessário apenas contar o número de diferenças entre seqüências e agrupar aquelas que são similares. A simplicidade deste algorítimo subestima a complexidade da inferência filogenética. A taxa de evolução das seqüências não é constante ao longo do tempo, de modo que a simples medida da diferença genética entre seqüências não é, necessariamente, uma indicação real de quando elas divergiram 
(Swofford et al. ${ }^{5}$ citado por Holder \& Lewis, 2003). Seleção natural ou mudanças de inclinações mutacionais durante a história de um organismo pode levar a que seqüências distantes divirjam mais lentamente que o esperado ou, mesmo, que se tornem mais similares em algumas regiões. Muitos dos sítios nas seqüências de DNA são úteis em reconstruções filogenéticas. Alguns sítios funcionais são invariáveis em relação a todas as seqüências conhecidas. Diferentemente, alguns sítios evoluem rapidamente e não são indicadores de proximidade. Devido a estas diferenças, freqüentemente várias hipóteses filogenéticas podem explicar os dados razoavelmente bem, possibilitando a construção de várias árvores diferentes. O pesquisador deve considerar este fato. Alguns métodos comumente utilizados ignoram esta incerteza e constroem uma única árvore hipotética, assumida como verdadeira. Análises adicionais são necessárias para mensurar o suporte do agrupamento das seqüências em cada uma das ramificações nas árvores filogenéticas (Holder \& Lewis, 2003).

O processo de inferência filogenética é, basicamente, composto por quatro etapas (Holder \& Lewis, 2003): 1) coleta das seqüências que serão comparadas; 2) alinhamento das seqüências (pareamento das bases de uma seqüência às de seqüências homólogas); 3) escolha de um modelo de evolução das seqüências (normalmente utilizam-se softwares que testam vários modelos e inferem os que melhor se adequam às seqüências sob análise); 4) a partir das seqüências em análise e dos modelos de evolução escolhidos, é criado um conjunto de árvores filogenéticas (utilizando-se os métodos de reconstrução filogenética, através das buscas de árvores múltiplas seguidas de "bootstrap” ou do algorítimo "Markov chain Monte Carlo” (MCMC)). Este conjunto de árvores fornecido pode ser resumido utilizando-se técnicas de “árvores consensus”, as quais mostram as partes das árvores que são encontradas na maioria ou em todas as árvores.

Os métodos tradicionalmente utilizados em reconstruções filogenéticas são o algorítimo NJ (Neighbour-Joining) e as árvores que utilizam critérios de optimização como parcimônia máxima (MP) ou probabilidade máxima (ML). Os princípios de cada

\footnotetext{
${ }^{5}$ SWOFFORD, D.L.; OLSEN, G.J.; WADDELL, P.J.; HILLS, D.M. In: HILLS, D.M.; MORITZ, C.;
}

MABLE, B.K. Molecular systematics. Sunderland: Sinauer Associates, 1996. p.407-514. 
um destes métodos, assim como vantagens e desvantagens foram apresentados por Holder \& Lewis (2003) e Solignac et al. (1995). A árvore NJ é normalmente considerada como ponto de partida para a busca da melhor filogenia, na qual utilizam-se programas computacionais. Nesta busca, deve-se estabelecer um critério de optimização (NJ, ML, MP etc...).

Os métodos de reconstrução filogenética tradicionais fornecem uma série de árvores filogenéticas possíveis a partir das seqüências analisadas. Não se sabe o quão fortemente os dados (seqüências) suportam as relações representadas nestas árvores. O método estatístico do bootstrap, proposto para estabelecer intervalos de confiança nas filogenias (Felsenstein, 1985), traz informação sobre a robusteza de cada ramificação. Este método tem sido o mais tradicionalmente utilizado em filogenia molecular, pois representa uma ferramenta versátil, que pode ser utilizada em qualquer tipo de análise. Um detalhamento sobre a metodologia estatística bootstrap pode ser encontrada em Solignac et al. (1995). De um modo geral, bootstrap fornece informação sobre quais partes das árvores apresentam baixo suporte. Comparações que dependem fortemente de ramificações com baixo suporte bootstrap devem ser feitas com precaução. A interpretação exata do valor bootstrap é relativa. Certamente, quanto mais alto o valor bootstrap obtido, melhor. Mas qual seriam os valores limite abaixo dos quais os agrupamentos deveriam ser considerados com precaução? Por tratar-se de uma medida conservadora de suporte, valores iguais ou superiores a $70 \%$ indicam forte suporte ao grupo. Deve-se ressaltar que as proporções bootstrap auxiliam na previsão das possibilidades de que as mesmas árvores sejam obtidas se mais dados forem coletados e, não, se o resultado é correto ou incorreto. Pode-se considerar que altas proporções bootstrap são condições necessárias, mas não suficientes para se ter alta confiabilidade em um grupo (Holder \& Lewis, 2003).

Uma nova abordagem filogenética, a abordagem Bayesiana, traz novas perspectivas para a biologia evolutiva, permitindo a análise de grandes árvores filogenéticas, a implementação de complexos modelos de evolução de seqüências e a detecção de marcas de seleção natural no DNA (Huelsenbeck et al., 2001). Um ponto forte dos métodos Bayesianos em relação aos outros métodos de estimação de árvores é 
que estes oferecem medidas estatísticas (probabilidades) das bifurcações. As inferências Bayesianas fornecem um método para estimar árvores filogenéticas e, simultaneamente, obter medidas de incerteza para cada ramo, chamadas de probabilidades posteriores (Holder \& Lewis, 2003). Os princípios e os processos estatísticos que constituem o alicerce das inferências Bayesianas foram detalhados em Huelsenbeck et al. (2001). Os métodos Bayesianos são baseados no algorítimo Markov chain Monte Carlo (MCMC), o qual é utilizado para aproximação de distribuição de probabilidades em uma grande variedade de contextos (Holder \& Lewis, 2003).

É possível que o bootstrap ou o MCMC suportem várias árvores que não apresentam a mesma topologia. Quando isto ocorre, o ideal seria apresentar as árvores de maior suporte nos resultados e discutir as discordâncias (Holder \& Lewis, 2003).

\subsection{Material e Métodos}

As análises moleculares das populações de A. guerreronis foram conduzidas com a colaboração e orientação da Dra. Maria Navajas, no "Centre de Biologie et Gestion des Populations” (CBGP), INRA, Monferrier-sur-Lez, Languedoc Roussillon, França.

Amostras de A. guerreronis de Cuba, México, Venezuela, EUA, Benin, Tanzânia, Índia e Sri Lanka foram enviadas por pesquisadores colaboradores, preservadas em álcool. Todas as amostras de A. guerreronis do Brasil (exceto as de Quissamã-RJ e de Ilha Bela-SP, coletadas por D. Navia) foram obtidas a partir de frutos de coco enviados por pesquisadores colaboradores ao Laboratório de Acarologia do Setor de Zoologia Agrícola, ESALQ-USP, Piracicaba, SP, Brasil, onde foram inspecionados. Em ambos os casos, os ácaros foram coletados da superfície inferior das brácteas ou da superfície dos frutos, sob estas, exceto no caso dos ácaros de San Diego, California, coletados de broto terminal de Syagrus romanzoffiana (Cham.) Glassm..

\section{Material Biológico}

Foram analisadas 30 amostras de A. guerreronis originárias de nove países e de duas plantas hospedeiras (Tabela 1, Figura 1): do coqueiro, C. nucifera (29 populações) 
e de jerivá, S. romanzoffiana (uma população). Em cada localidade foram coletados pelo menos 100 ácaros, com o auxílio de um pincel de ponta fina, da região meristemática dos frutos de coco ou do broto terminal de plantas jovens de jerivá, ao estereoscópio (aumento de 30x). Cerca de 50 ácaros foram preservados em álcool etílico a 70\%, para preparação de lâminas e realização das análises morfológicas/morfométricas. Os demais foram preservados em etanol a $100 \%$ e mantidos a $0^{\circ} \mathrm{C}$, para as análises moleculares. Os ácaros preservados em álcool a 70\% foram, posteriormente, montados em lâminas de microscopia para confirmação da identificação da espécie através de avaliações morfológicas. Uma amostra de Aceria ficus (Cotte) foi coletada de folhas jovens e gemas de Ficus carica L., na École Nationale Superiéure Agronomique - Montpellier, Languedoc-Roussillon, França, para ser utilizada como grupo externo nas comparações de seqüências de ITS.

\section{Análises moleculares de DNA - extração, amplificação e sequenciamento}

\section{Extração}

O DNA genômico foi extraído de espécimes de A. guerreronis utilizando-se o kit de extração para cultura de células "Quiagen DNeasy" ® de acordo com as instruções gerais do fabricante, modificado para ácaros de dimensões reduzidas, como descrito a seguir. Testes preliminares de extração de DNA de um único ácaro adulto mostraram que a quantidade de DNA obtida não seria suficiente para a amplificação. Desta forma a extração foi feita de grupos de 25 ácaros adultos de cada população. Cada grupo de ácaros foi separado em tubo estéril de 1,5 ml para microcentrífuga contendo etanol absoluto. Os ácaros foram peletizados através de centrifugação a 13.000 rpm, durante 30 min, a $4^{\circ} \mathrm{C}$. Com uma micro-pipeta, quase todo o etanol foi removido e o tubo foi, em seguida, centrifugado a vácuo, à temperatura ambiente, por 5-10 min, para completa eliminação do etanol. Solução tampão PBS $(90 \mu \mathrm{l})$ foi adicionada ao tubo e os ácaros foram macerados com uma mão de almofariz plástica (plastic pestle). Adicionou-se, então, $10 \mu l$ de proteinase $\mathrm{K}$, seguida de $100 \mu \mathrm{l}$ de tampão AL e $5 \mu \mathrm{l}$ de RNA carreador. A solução foi completamente homogeneizada com um vórtex e incubada a $70^{\circ} \mathrm{C}$ por 10 
Tabela 1. Amostras de A. guerreronis analisadas. Locais de coleta, regiões do genoma seqüenciadas e código de cada amostra

\begin{tabular}{|c|c|c|c|c|}
\hline Continente & País & Localidade & $\begin{array}{c}\text { Região } \\
\text { Sequenciada }\end{array}$ & Código \\
\hline \multirow[t]{3}{*}{ África } & Benin & Ipinkle & ITS, 16S, CO-I & Ben1 \\
\hline & & Ouidah & ITS, 16S, CO-I & Ben2 \\
\hline & Tanzânia & Micuranga & ITS, 16S, CO-I & Tan \\
\hline \multirow[t]{15}{*}{ América } & Brasil & Ilha Bela, São Paulo & ITS, 16S, CO-I & Br1 \\
\hline & & Lagarto, Sergipe & ITS & Br2 \\
\hline & & Aracaju, Sergipe & $16 \mathrm{~S}$ & Br3 \\
\hline & & Quissamã, Rio de Janeiro & ITS, $16 S$ & $\mathrm{Br} 4$ \\
\hline & & Janaúba, Minas Gerais & ITS, $16 S$ & $\operatorname{Br} 5$ \\
\hline & & Recife, Pernambuco & ITS, $16 S$ & Br6 \\
\hline & & Petrolina, Pernambuco & $16 S$ & Br7 \\
\hline & & Maceió, Alagoas & ITS, $16 \mathrm{~S}$ & Br8 \\
\hline & & São Felix, Bahia & ITS, 16S & Br9 \\
\hline & & Ilhéus, Bahia & 16S, CO-I & Br10 \\
\hline & Cuba & Havana & $16 \mathrm{~S}$ & Cub \\
\hline & EUA & San Diego, Califórnia & ITS, $16 \mathrm{~S}$ & EUA1 \\
\hline & & Fort Laudedale, Florida & ITS, 16S & EUA2 \\
\hline & México & Atoyac Alvarez, Guerrero & ITS, 16S, CO-I & Mex \\
\hline & Venezuela & Paéz, Zulia & ITS, $16 S$ & Ven \\
\hline \multirow[t]{11}{*}{ Ásia } & India & Kayankulam, Kerala & ITS, 16S, CO-I & Ind1 \\
\hline & & Kasaragod, Kerala & ITS, 16S, CO-I & Ind2 \\
\hline & Sri Lanka & Kalpitiya & ITS, 16S, CO-I & SrL1 \\
\hline & & Madurankuliya & 16S, CO-I & SrL2 \\
\hline & & Wanathawilluwa & ITS, 16S, CO-I & SrL3 \\
\hline & & Yakwila & ITS, 16S, CO-I & SrL4 \\
\hline & & Haldanduwana & ITS, $16 \mathrm{~S}$ & SrL5 \\
\hline & & Unagala Vehera & ITS, 16S, CO-I & SrL6 \\
\hline & & Madampe & ITS, 16S, CO-I & SrL7 \\
\hline & & Laksha Uyana & 16S, CO-I & SrL8 \\
\hline & & Hingurakgoda & $16 \mathrm{~S}$ & SrL9 \\
\hline
\end{tabular}

min. Então, $100 \mu$ l de etanol absoluto foi adicionado ao tubo e misturado à solução, utilizando-se o vórtex. A mistura foi transferida para uma coluna "DNeasy" colocada sobre um tubo de coleta de $2 \mathrm{ml}$ e centrifugada a $8.000 \mathrm{rpm}$ por $1 \mathrm{~min}$, a $4^{\circ} \mathrm{C}$. A solução que passou pela coluna e o tubo de coleta foram descartados e a coluna transferida para 


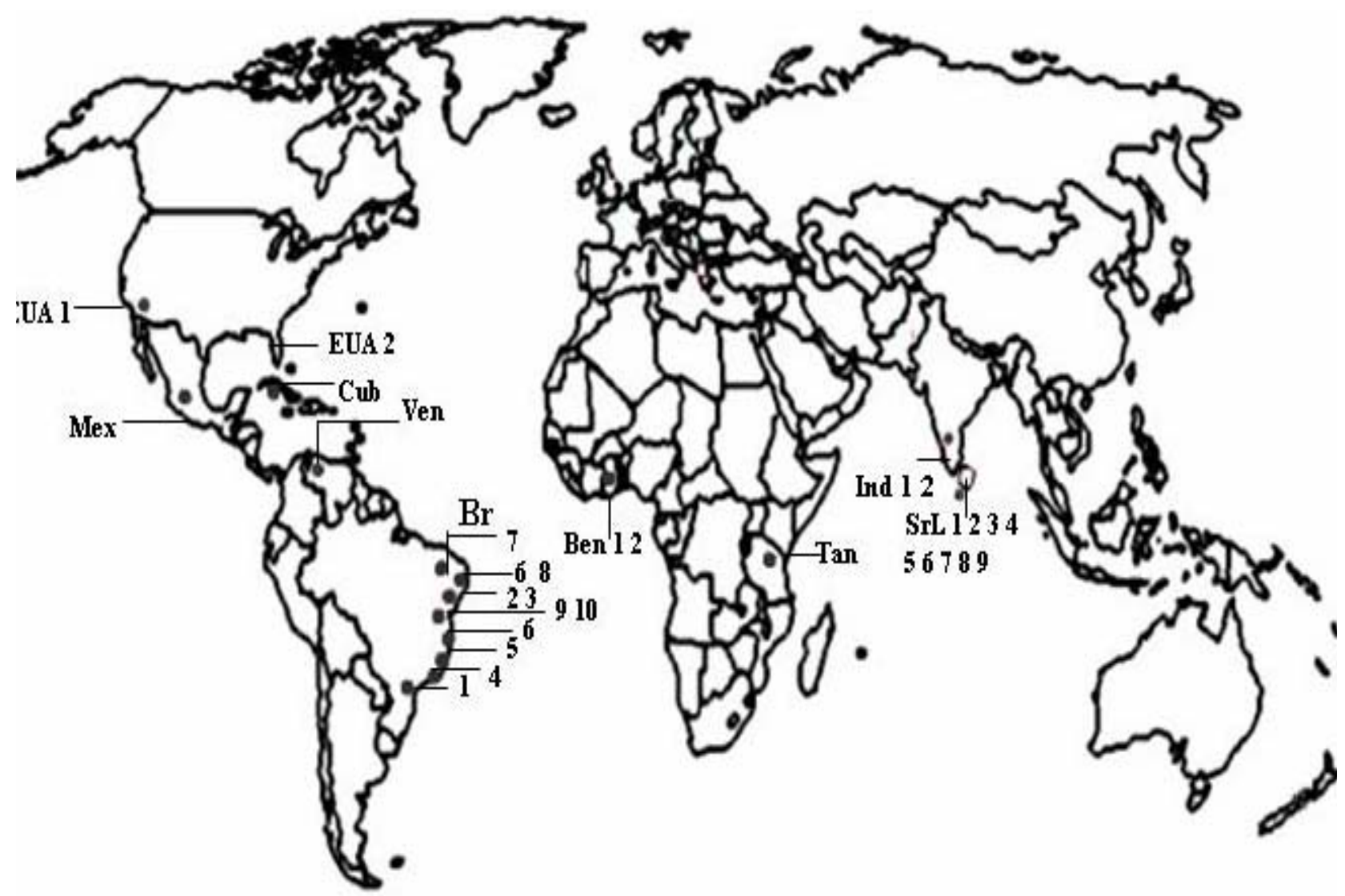

Figura 1- Locais de coleta das amostras de A. guerreronis analisadas. Códigos representam as localidades de coleta das amostras especificadas na Tabela 1 
um novo tubo coletor de $2 \mathrm{ml}$. Adicionaram-se, então, $250 \mu \mathrm{l}$ de tampão AW1 e o tubo foi centrifugado a $8.000 \mathrm{rpm}$ durante $1 \mathrm{~min}$, a $4^{\circ} \mathrm{C}$. A coluna foi transferida para um novo tubo coletor de $2 \mathrm{ml}$, e adicionou-se $250 \mu \mathrm{l}$ de tampão AW2, centrifugando-se o tubo a $13.000 \mathrm{rpm}$, por $3 \mathrm{~min}$, a $4^{\circ} \mathrm{C}$, para eliminar todo etanol antes da elução. A coluna foi, então, acoplada a um tubo de 1,5ml, $50 \mu \mathrm{l}$ de água ultrapura foram colocados sobre a membrana da coluna, o tubo foi incubado durante 10 min e centrifugado, a $8.000 \mathrm{rpm}$, por $2 \min$ a $4^{\circ} \mathrm{C}$.

\section{Amplificação através de PCR (Polymerase Chain Reaction)}

Foram amplificados fragmentos de cerca de 1000pb da região ITS1-5.8S-ITS2 do rDNA; de 404 pb da região 16S do mtDNA; e de 500 pb da região CO-I do mtDNA.

A amplificação através de PCR do ITS foi realizada utilizando-se os primers 5' AGA GGA AGT AAA AGT CGT AAC AAG 3' e 5' ATA TGC TTA AAT TCA GGG GG 3', localizados respectivamente na extremidade 3' do 18rDNA e na extremidade 5' do 28S. Cada reação PCR foi conduzida em $25 \mu \mathrm{l}$ de volume de reação contendo 2,5 $\mu \mathrm{l}$ de tampão 10x Taq Polymerase (Qiagen), 1 U de Taq Polymerase (Qiagen), 0.25 mM de cada dNTP, $0.5 \mu \mathrm{M}$ de cada primer oligonucleotídeo, $5 \mu \mathrm{l}$ de solução Q, $2.5 \mathrm{mM}$ de $\mathrm{MgCl}_{2}$ e $2 \mu \mathrm{l}$ do DNA a ser amplificado. As amostras foram desnaturadas a $94^{\circ} \mathrm{C}$ durante 4 min e então a PCR foi conduzida por 35 ciclos de $30 \mathrm{~s}$ de desnaturação a $94^{\circ} \mathrm{C}$, 30 s de anelamento a $50^{\circ} \mathrm{C}$ e 1 min de extensão a $72^{\circ} \mathrm{C}$.

Para a obtenção das seqüências completas de ITS do rDNA realizou-se a clonagem. Foram conduzidas 8 reações PCR por amostra de DNA e o produto obtido foi reunido e purificado, cortando-se as bandas-alvo de gel de agarose, seguido pela purificação do DNA utilizando-se o kit de extração "QIAquick" (Qiagen). Os fragmentos recuperados foram ligados ao sitema vetor "pGEM-T Easy" (Promega). Os fragmentos ligados foram transfectados dentro da linhagem XL1-Blue de Echerichia coli. Foram sequenciados de dois a três clones positivos por transformação bemsucedida.

O fragmento 16S foi amplificado utilizando-se os primers PCR LR-J 12887 (5' CCG GTC TGA ACT CAG ATC ACG T 3') e LR-N 13398 (5' CGC CTG TTT AAC 
AAA AAC AT 3') (Simon et al., 1994). As reações de PCR e as temperaturas utilizadas em cada etapa da reação foram as mesmas descritas para o ITS, exceto pela temperatura de anelamento, que foi de $53^{\circ} \mathrm{C}$. Sete reações PCR foram realizadas para cada amostra de DNA e os produtos destas reações foram reunidos e purificados cortando-se as bandas-alvo do gel de agarose. O DNA foi purificado do gel utilizando-se o "kit QIAquick" (Qiagen) para extração de DNA de gel de agarose. O produto foi seqüenciado diretamente.

A região CO-I foi amplificada utilizando-se os primers C1-J 1751 (5' GGA TCA CCT GAT ATA GCA TTC CC 3') e C1-N 2191 (5' CCC GGT AAA ATT AAA ATA TAA ACT TC 3') (Simon et al., 1994). Duas reações de PCR subseqüentes foram conduzidas para a obtenção de uma maior quantidade de DNA amplificado. Na primeira, os $25 \mu$ de reação continham 2,5 $\mu$ de tampão 10x Taq Polymerase (Promega), $1 \mathrm{U}$ Taq Polymerase (Promega), 0,25 $\mathrm{mM}$ de cada DNTP, 0,5 $\mu \mathrm{M}$ de cada primer oligonucleotídeo, 2,5 mM de $\mathrm{MgCl}_{2}$, 0,8 $\mu \mathrm{l}$ de soro de albumina bovina e $4 \mu \mathrm{l}$ de amostra de DNA. O protocolo de amplificação utilizado foi o mesmo descrito para o ITS, diferindo apenas pela temperatura de anelamento, que foi de $42^{\circ} \mathrm{C}$. O produto do PCR foi separado em gel de agarose de $1,5 \%$ e a banda apropriada cortada utilizando-se uma lâmina estéril. O DNA amplificado foi elucionado do gel, cobrindo-o com água ultrapura (cerca de $50 \mu \mathrm{l}$ ) e incubando-o por $2-3$ dias a $5^{\circ} \mathrm{C}$ em um tubo de $1,5 \mathrm{ml}$ (Salomone et al., 2002). A concentração de DNA da solução resultante foi estimada por gel de agarose. Para isto, utilizaram-se $2 \mu \mathrm{l}$ da solução contendo o DNA recuperado como molde para a segunda PCR, para a obtenção de uma quantidade de DNA suficiente para o sequenciamento. Nesta segunda reação, a temperatura de anelamento foi de $60^{\circ} \mathrm{C}$. O produto foi diretamente seqüenciado.

\section{Sequenciamento}

Para o sequenciamento dos três fragmentos utilizou-se o método "BigDye Terminator" (Perkin Elmer, Foster City, CA) em um seqüenciador de DNA automatizado ABI PRISM 377 (Applied Biosystems Inc.). Ambos os primers (extremidades 3'e 5') utilizados nas reações PCR para as regiões ITS e CO-I foram 
utilizados para o sequenciamento destas respectivas regiões. Somente o primer LR-N 13398 foi utilizado para o sequenciamento da região 16S.

Cada uma das distintas seqüências das regiões ITS, 16S e CO-I de A. guerreronis obtidas foram depositadas na base de dados EMBL e estarão disponíveis após a publicação do trabalho. Os alinhamentos de todas as seqüências estão disponíveis com M. Navajas e D. Navia.

\section{Alinhamento e Análise Filogenética}

As seqüências foram alinhadas utilizando-se o programa CLUSTAL W (Thompson et al., 1994), aplicando-se os parâmetros padrões do programa e, em seguida, manualmente editado utilizando-se o programa BioEdit (Hall, 1999).

Foram utilizados três métodos de análises filogenéticas: probabilidade máxima (ML), parcimônia máxima (MP) e inferência Bayesiana. O programa Modeltest versão 3.06 (Posada \& Crandall, 1998, 2001) foi utilizado para encontrar o modelo de substituição que mais se adequava ao conjuntos de dados.

Para as análises ML e MP, utilizou-se o programa PAUP* versão 4.0b8 (Swofford, 2001). Buscas eurísticas foram realizadas utilizando-se o critério de parcimônia otimizado. Realizaram-se análises bootstrap (1000 replicações) para avaliar os níveis relativos de suporte para cada nodo das árvores filogenéticas.

As análises Bayesianas com as cadeias de Markof, amostragem Monte Carlo, foram realizadas com o programa MrBayes v.2.01 (Hughes \& Queller, 1993) corridos para 1 milhão de gerações e amostrado uma vez a cada 1000 árvores. Nestas análises, as distribuições dos escores de probabilidades foram projetadas para estimar o tempo de convergência e o número de árvores a serem descartadas como o burn in da cadeia. Em seguida, calcularam-se as probabilidades posteriores dos nodos nas árvores remanescentes amostradas. Todas as análises foram conduzidas por três vezes, partindo das árvores aleatórias. Após descartar o burn in, os resultados de cada uma das corridas foram comparados. Quando as médias dos valores estimados foram similares para todos os parâmetros, estes foram considerados como tendo convergência. As probabilidades 
dos clados ${ }^{6}$ também foram comparadas entre as três corridas para cada conjunto de dados de modo a assegurar congruência.

\section{Medidas de variação genética e estrutura de populações}

Os índices de diversidade das seqüências, incluindo o número de sítios segregantes, número de haplótipos, diversidade de haplótipos e diversidade de nucleotídeos foram estimados utilizando-se o programa ARLEQUIN 2.0 (Schneider et al., 2000). Matrizes de divergência de nucleotídeos pareados baseados na distância dos parâmetros de Kimura -2 foram calculados com MEGA 2 (Kumar et al., 1993).

A estrutura das populações foi determinada através da análise de variância molecular (AMOVA), método de Excoffier (Excoffier et al.,1992), como implementado pelo programa ARLEQUIN 2.0 (http:// anthro.unige.ch/arlequin). AMOVA subdivide a diversidade genética em componentes hierárquicos. Nesta análise, foram consideradas duas regiões geográficas: 1) Brasil e 2) demais localidades da América (Cuba; Flórida e Califórnia, EUA; México e Venezuela). Os componentes de variância incluídos nesta análise foram: 1) entre todas as localidades em cada região e 2) dentro das localidades em cada região. A diferenciação genética também foi estudada utilizando-se os estimadores $\Phi_{\mathrm{ST}}$ calculados entre as amostras coletadas nas duas regiões geográficas A e B. A significância estatística dos componentes de variância e dos índices $\Phi_{\mathrm{ST}}$ foram avaliados por aleatorização (ver Excoffier et al. 1992).

\subsection{Resultados e Discussão}

\section{Sequenciamento}

No total, 95 seqüências foram obtidas das três regiões genômicas (52 para o ITS, 28 para o 16S e 15 para o CO-I) das 29 amostras (Tabela 1). Não foi possível sequenciar

\footnotetext{
${ }^{6}$ Clado - uma linhagem evolucionária derivada de uma única espécie-tronco (stem species). O ramo de um cladograma (representação gráfica que representa uma árvore construída através do princípio da parcimônia ou que reflita as relações históricas entre os organismos) (Hoy, 1994).
} 
as três regiões para todas as populações devido a problemas em obter amplificação de DNA através de PCR, provavelmente devido ao estado de degradação dos espécimes de algumas populações. As maiores dificuldades foram encontradas para a amplificação da região CO-I, da qual seqüências de apenas 15 populações foram obtidas. Devido ao reduzido número de seqüências da região CO-I obtidas, representando poucas populações, estas não foram submetidas apenas às análises filogenéticas, mas não às de diversidade genética.

Para a região ITS de A. guerreronis, após a exclusão de sítios ambíguos, o alinhamento apresentou 987 posições, das quais 111 são variáveis e 52 foram informativos para métodos de parcimônia (Anexo A). A região ITS de A. ficus também foi seqüenciada, mas não foi possível alinhar esta seqüência com as das populações de A. guerreronis, por ser muito mais longa (1170 pb, isto é, quase $200 \mathrm{pb}$ a mais) e apresentarem alguns sítios demasiadamente distintos. Para a região 16S, o alinhamento apresentou 404 posições, incluindo 28 sítios de variação e 22 foram informativos para métodos de parcimônia (Anexo B). Para a região CO-I, o alinhamento apresentou 494 posições, incluindo 216 sítios de variação (Anexo C).

Apesar das seqüências CO-I não haverem sido submetidas às análises de diversidade, observou-se que os resultados desta região de mtDNA foram concordantes com os das seqüências 16S. Observou-se uma grande variabilidade nas seqüências de três populações americanas (Br1, Br10, e Mex), havendo divergência de grupos de nucleotídeos por toda sua extensão, sendo marcadamente distintas das demais, enquanto que as seqüências das demais. As seqüências das populações africanas e asiáticas mostraram-se extremamente homogêneas, observando-se apenas algumas substituições de bases isoladas (Anexo C). Portanto, os resultados das seqüências CO-I mostram: 1) uma grande variabilidade genética entre as populações da América; 2) homogeneidade entre as populações da África e Ásia; 3) marcante distinção entre as populações da América em relação às populações da África e Ásia.

Para verificar se havia variação entre as diferentes cópias do rDNA de uma mesma população de A. guerreronis, foram clonados os produtos de PCR da região ITS e seqüenciados vários clones dos moldes de DNA de indivíduos de cada população. Os 
diferentes clones de DNA de cada população produziram de uma a três seqüências diferentes.

Os limites da subunidade 5,8S foram determinados através de comparação com as seqüências de ácaros da família Ixodidae (Wesson \& Collins, 1992) e Phytoseiidae (Navajas et al., 1999) assim como de outras seqüências disponíveis em bancos de dados. Entretanto, os limites entre o ITS1 e a região 18S e entre o ITS2 e a região 28S não puderam ser determinados com precisão.

\section{Variação genética e estrutura das populações}

\section{Região ITS do rDNA}

Foram encontradas 47 seqüências diferentes da região ITS entre as 52 seqüências obtidas de 22 amostras. Entre as 23 seqüências de espécimes da América, 14 foram encontradas no Brasil, as quais incluíram 63 sítios polimórficos. Outras nove seqüências de ITS foram encontradas nas amostras dos outros países da América (EUA, México e Venezuela). As demais seqüências pertenciam a amostras coletadas na África (5 seqüências) e na Ásia (19 seqüências) (Anexo A).

A diversidade mais alta para a região ITS foi detectada no Brasil, com 1,90\% da diversidade de nucleotídeos comparada com 0,54\% de diversidade nas amostras das demais localidade da América, 0,70\% na África e 0,49\% na Ásia (Tabela 2).

Na maioria dos casos, os dois ou três diferentes clones seqüenciados por amostra foram idênticos ou muito próximos. Para sete amostras (Ilha Bela, Brasil; San Diego, EUA; Fort Lauderdale, EUA; Kayangulam, Índia; Wanathawilluwa e Haldanduwana, Sri Lanka), um dos dois ou três clones analisados apresentaram seqüências divergentes. Entretanto, as seqüências dos vários clones obtidos para uma determinada amostra sempre se posicionaram em clados que reuniram amostras de populações da mesma região geográfica (América, África ou Ásia) (Figura 2).

\section{Região 16S do mtDNA}

Foram detectados sete haplótipos diferentes para a região 16S nas populações de A. guerreronis analisadas, dos quais seis são de populações americanas. Todas as outras 
14 populações, 3 da África e 11 da Ásia, compartilharam um mesmo haplótipo. A diversidade mais alta foi encontrada entre populações do Brasil, onde os seis haplótipos americanos foram representados. O haplótipo apresentado na população brasileira de Quissamã (Br4) foi o mais próximo aos haplótipos detectados em todas as populações dos outros países americanos: Cuba (Cub), EUA, México (Mex) e Venezuela (Ven). A diversidade haplótica da América representa uma diversidade de genes de 0,85 com um número médio de diferenças entre haplótipos de 8,93\% (Tabela 2). A divergência de nucleotídeos nas Américas variou de 1 a 3,44\%. Assim como para a região ITS, a maior diversidade encontrada na região 16S foi detectada no Brasil.

As análises de distribuição da variação genética entre regiões geográficas nas Américas foi complementada por AMOVA. Esta análise mostrou que a contribuição da diversidade total das seqüências obtidas para ácaros coletados dentro de cada uma das duas regiões comparadas (Brasil e demais localidade Americanas) foi mais alta $(75,5 \%$ para a região ITS e 79,5\% para a região $16 S)$ que entre estas regiões (24,5\% para ITS e 20,5\% para $16 S)(p<0,001$; Tabela 3).

Tabela 2. Índices de diversidade molecular estimados de seqüências da região ITS do rDNA (A) e da região 16S do mtDNA (B) obtidas a partir de amostras de $A$. guerreronis coletados em três continentes

\begin{tabular}{lcccccc}
\hline \multicolumn{1}{c}{$\begin{array}{c}\text { Origem } \\
\text { geográfica }\end{array}$} & $\begin{array}{c}\text { No. } \\
\text { cópias } \\
\text { de genes }\end{array}$ & $\begin{array}{c}\text { No. } \\
\text { haplótipo } \\
\text { s }\end{array}$ & $\begin{array}{c}\text { No. } \\
\text { sítios } \\
\text { polimór } \\
\text { ficos }\end{array}$ & $\begin{array}{c}\text { Diversidade } \\
\text { gênica }\end{array}$ & $\begin{array}{c}\text { Média das } \\
\text { diferenças de } \\
\text { pareamentos* }\end{array}$ & $\begin{array}{c}\text { Diversidade de } \\
\text { nucleotídeos } \\
\text { (\%) }\end{array}$ \\
\hline A & & & & & & \\
América ( $\neq$ Brasil) & 10 & 9 & 24 & $0,9778 \pm 0,054$ & $5,11 \pm 2,71$ & $0,54 \pm 0,32$ \\
Brasil & 15 & 14 & 63 & $0,9905 \pm 0,028$ & $18,05 \pm 8,49$ & $1,90 \pm 1,00$ \\
África & 5 & 5 & 16 & $1,0000 \pm 0,126$ & $6,60 \pm 3,75$ & $0,70 \pm 0,46$ \\
Ásia & 22 & 19 & 31 & $0,9870 \pm 0,017$ & $4,59 \pm 2,34$ & $0,49 \pm 0,28$ \\
B & & & & & & \\
América & 14 & 6 & 26 & $0,8462+0,0742$ & $8,93+4,38$ & $2,22+1,22$ \\
Ásia \& África & 14 & 1 & 0 & 0 & 0 & 0 \\
\hline
\end{tabular}

\section{* sem correção gamma}


Tabela 3. Análise de variância molecular (AMOVA) para amostras americanas de $A$. guerreronis baseadas em seqüências da região 16S do mtDNA (A) e ITS do rDNA (B). As amostras foram divididas em dois grupos: 1) Brasil e 2) Cuba, EUA (Califórnia e Flórida), México e Venezuela. Graus de liberdade (g.l), soma dos desvios quadrados (SDQ), estimativas dos componentes de variância, porcentagens da variância total por cada componente e teste de probabilidade $P$-valor calculado para 1.000 permutações

\begin{tabular}{lccccc}
\hline Fonte de variação & g.l & SDQ & $\begin{array}{c}\text { Componente } \\
\text { de variância }\end{array}$ & $\begin{array}{c}\text { \% da } \\
\text { variação total }\end{array}$ & P-valor \\
\hline A & 1 & 10,51 & 1,02 & 20,46 & $<0,001$ \\
entre regiões & 12 & 47,55 & 3,96 & 79,54 & $<0,001$ \\
dentro da região & 13 & 58,07 & 4,98 & & \\
Total & & & & & \\
B & 1 & 31,83 & 2,11 & 24,54 & $<0,001$ \\
entre regiões & 23 & 149,33 & 6,49 & 75,46 & $<0,001$ \\
dentro da região & 24 & 181,16 & 8,60 & & \\
Total & & & & & \\
\hline
\end{tabular}

\section{Análises Filogenéticas}

Os modelos que mais se adequaram para as seqüências ITS e 16S obtidas foram, respectivamente: o HKY com uma taxa Ti/Tv de 1,7987 e o K80+G com uma taxa Ti/Tv de 2,8257 (ver descrição do modelo em Posada \& Crandall, 2001)

As árvores filogenéticas construídas para as três regiões do genoma utilizando MP, ML e os métodos Bayesianos foram muito similares e nenhuma diferença topológica foi encontrada entre os resultados obtidos utilizando-se estes três métodos filogenéticos.

Na filogenia encontrada ao se considerar as seqüências ITS, utilizando-se as inferências Bayesianas, as amostras foram separadas em dois agrupamentos fortemente suportados (probabilidade posterior de 99\%). Um clado agrupou todas as seqüências da América e o outro, aquelas da África e da Ásia (Figura 2).

A filogenia encontrada utilizando-se inferências Bayesianas mostrou probabilidade posterior de 90\% ou superior na maioria dos nodos na árvore construída a 
partir das seqüências 16S (Figura 3). Na árvore obtida considerando-se as seqüências 16S, assim como na árvore ITS, as amostras foram separadas em dois clados principais, um contendo todas as amostras da América e o outro agrupando as populações da África e Ásia, as quais foram não-polimórficas. Entre as amostras da América, a maior diversidade das amostras no Brasil é claramente representada na árvore, com três ramos contendo seqüências do Brasil e somente um contendo as seqüências das demais localidades da América. As amostras mais distantes entre as de origem americana foram aquelas agrupadas no clado de forte suporte (100\% de probabilidade posterior), incluindo três amostras de origem brasileira: Aracaju, SE (Br3); Petrolina, PE (Br7) e Maceió, AL (Br8). Assim como para a árvore obtida considerando-se as seqüências ITS, na árvore $16 \mathrm{~S}$ a população brasileira de Quissamã-RJ (Br4) está próxima às populações dos demais países da América (Figura 2).

Na filogenia encontrada ao se considerar as seqüências CO-I, obtidas através das inferências Bayesianas, as amostras foram separadas em três agrupamentos: 1) África e Ásia; 2) México; 3) Brasil. Dois clados, um agrupando as populações da África \& Ásia e o outro com as populações do Brasil, foram fortemente suportados (probabilidade posterior de 99\%) (Figura 4).

Embora nem todas as amostras tenham sido seqüenciadas para as três regiões do genoma (ITS, 16S e CO-I), observou-se que a topologia geral dos clados foi congruente entre as três árvores filogenéticas obtidas através das inferências Bayesianas.

Os dois principais clados, o americano e o afro-asiático, obtidos nas três árvores, refletiram predominantemente uma estrutura geográfica relacionada ao restrito fluxo gênico entre as populações de um e de outro daqueles clados, determinado por fatores geográficos naturais.

As análises das seqüências nucleares (ITS) e mitocondriais (16S e CO-I) revelaram substancial estrutura populacional entre as populações de A. guerreronis coletadas nos três diferentes continentes, isto é, populações de um mesmo continente foram agrupadas ou permaneceram mais próximas entre si, que de populações de distintos continentes. 
Apesar da clara separação entre os dois grupos de populações (Figuras 2, 3 e 4), a quantidade de divergência entre nucleotídeos sugere que os ácaros dos dois grupos pertencem à mesma espécie, se levarmos em consideração os resultados obtidos com uma outra espécie de ácaro. A máxima divergência de nucleotídeos da região CO-I entre linhagens do ácaro rajado, T. urticae, calculada de amostras da espécie de uma ampla distribuição geográfica, foi de 5\% (Navajas et al, 1998a).

As filogenias construídas a partir das seqüências ITS, 16S e CO-I são, em aspectos gerais, concordantes com os resultados obtidos através das análises de morfometria multivariada tradicional (Análise dos Componentes Principais e Análise de Variáveis Canônicas) (Capítulo 7) e das análises de morfometria geométrica (Análise de Deformações Relativas e Parciais) (Capítulo 8), nas quais foram consideradas, em sua quase totalidade, amostras das mesmas localidades submetidas às análises moleculares. As análises morfométricas mostraram que há variabilidade morfológica significativa entre as populações de A. guerreronis. A maior variabilidade morfológica foi detectada entre as populações da América, especialmente entre as populações do Brasil. Ambas análises morfométricas mostraram que há um padrão geográfico de variação morfológica quando as amostras foram consideradas em termos de continentes, pois populações de um mesmo continente formaram agrupamentos. As populações da África e Ásia foram sobrepostas nas análises morfométricas, indicando que são morfologicamente próximas e se distanciaram das populações da América. Na América, as populações de Cuba, EUA, México e Venezuela sempre foram agrupadas. Estes resultados são altamente concordantes com os obtidos no presente estudo.

Outros detalhes concordantes existem entre as análises moleculares e as morfométricas. As filogenias ITS e 16S mostraram que a população de A. guerreronis de Quissamã (Br4) é mais próximas às populações não brasileiras da América (Cub, EUA1, EUA2, Mex, Ven), que às demais populações brasileiras. Este mesmo resultado foi obtido através das Análises de Morfometria Geométrica (Capítulo 8). 


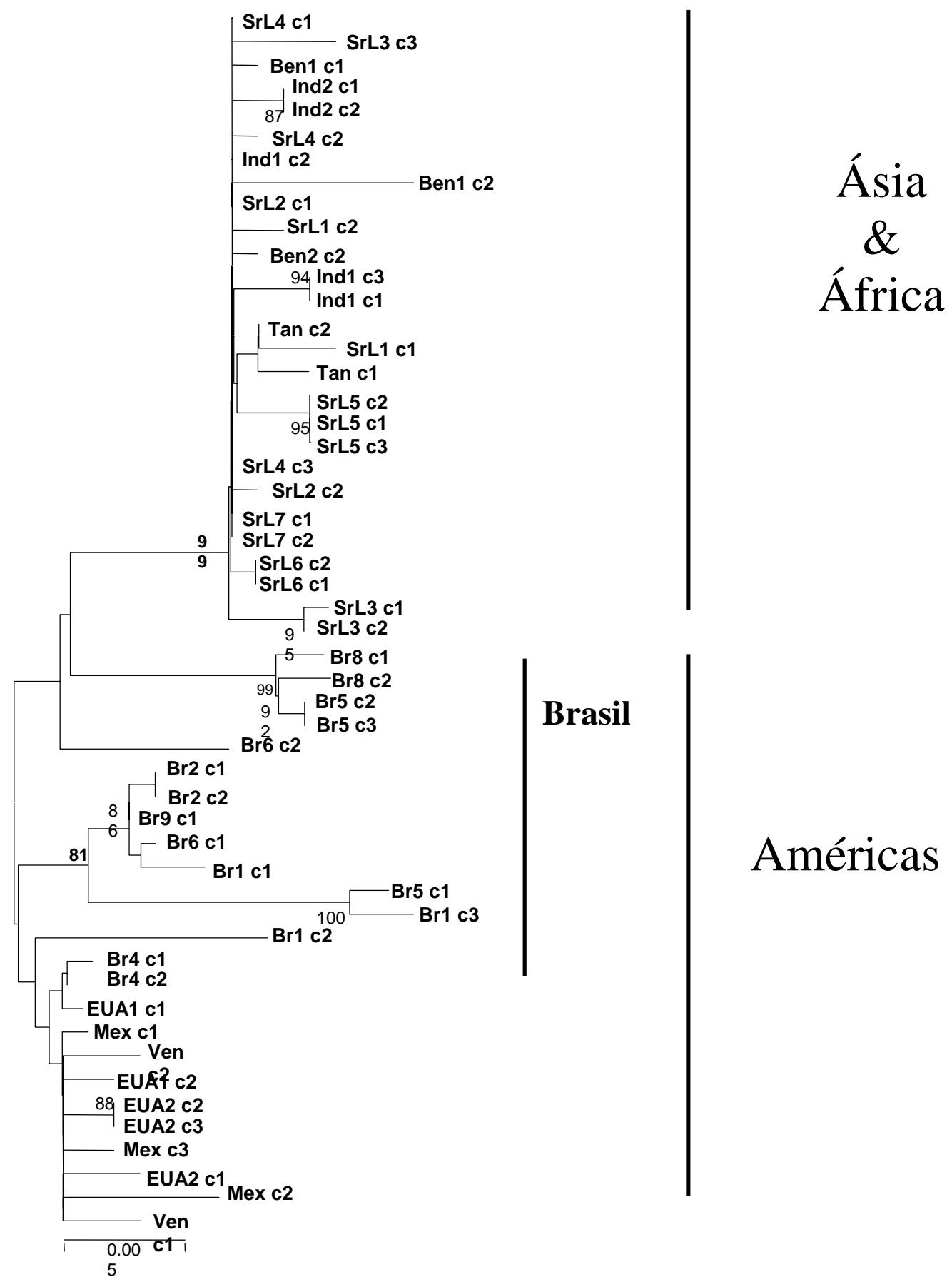

Figura 2 - Filogenia de populações de A. guerreronis baseada em seqüências da região ITS do rDNA, construída através de inferências Bayesianas. Os valores próximos aos nodos representam as probabilidades posteriores de suporte. Os códigos representam as localidades de coleta das amostras especificadas na Tabela 1 


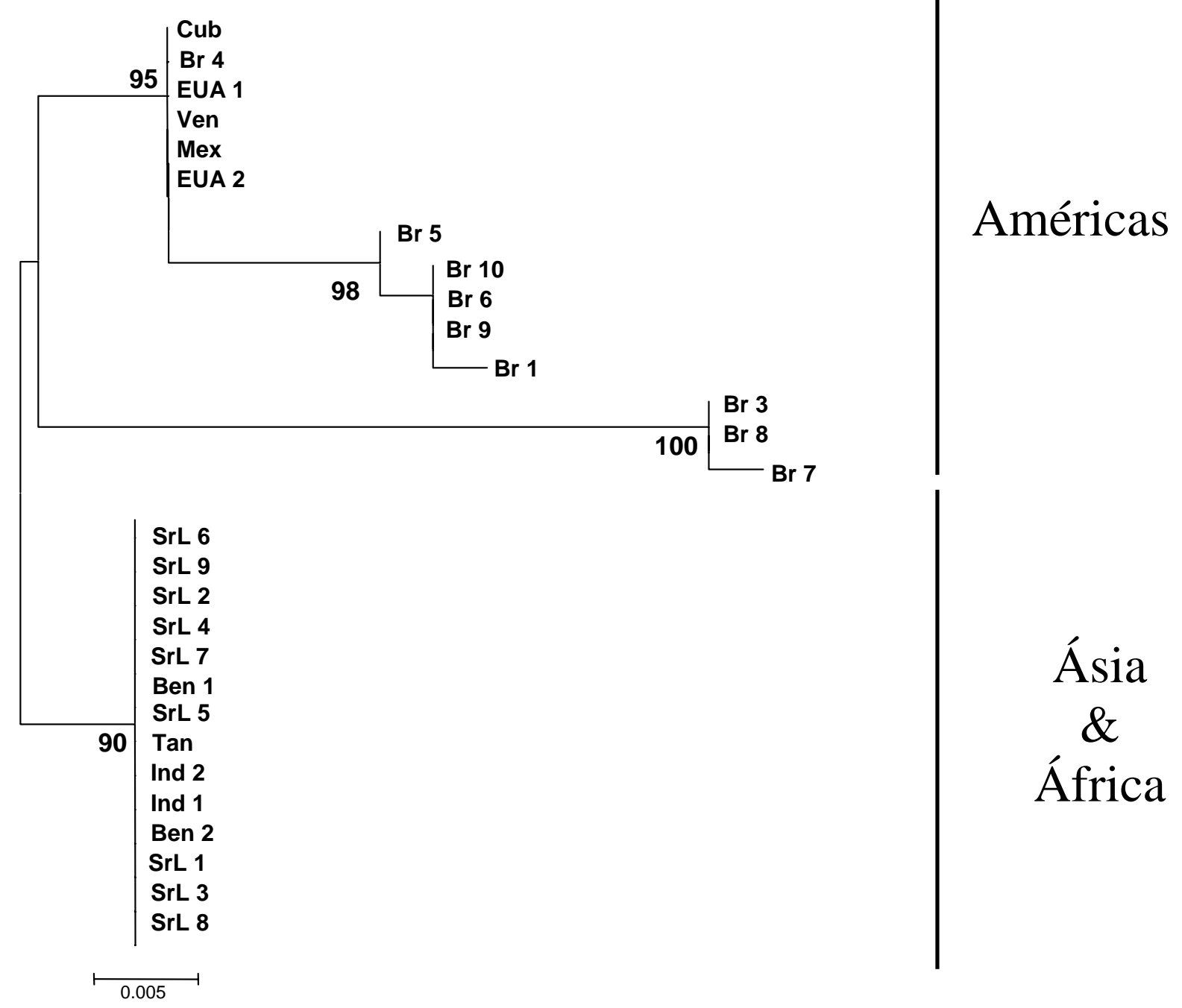

Figura 3 - Filogenia de populações de A. guerreronis baseada em seqüências da região 16S do mtDNA, construída através de inferências Bayesianas. Os valores próximos aos nodos representam as probabilidades posteriores de suporte. Códigos representam as localidades de coleta das amostras especificadas na Tabela 1 


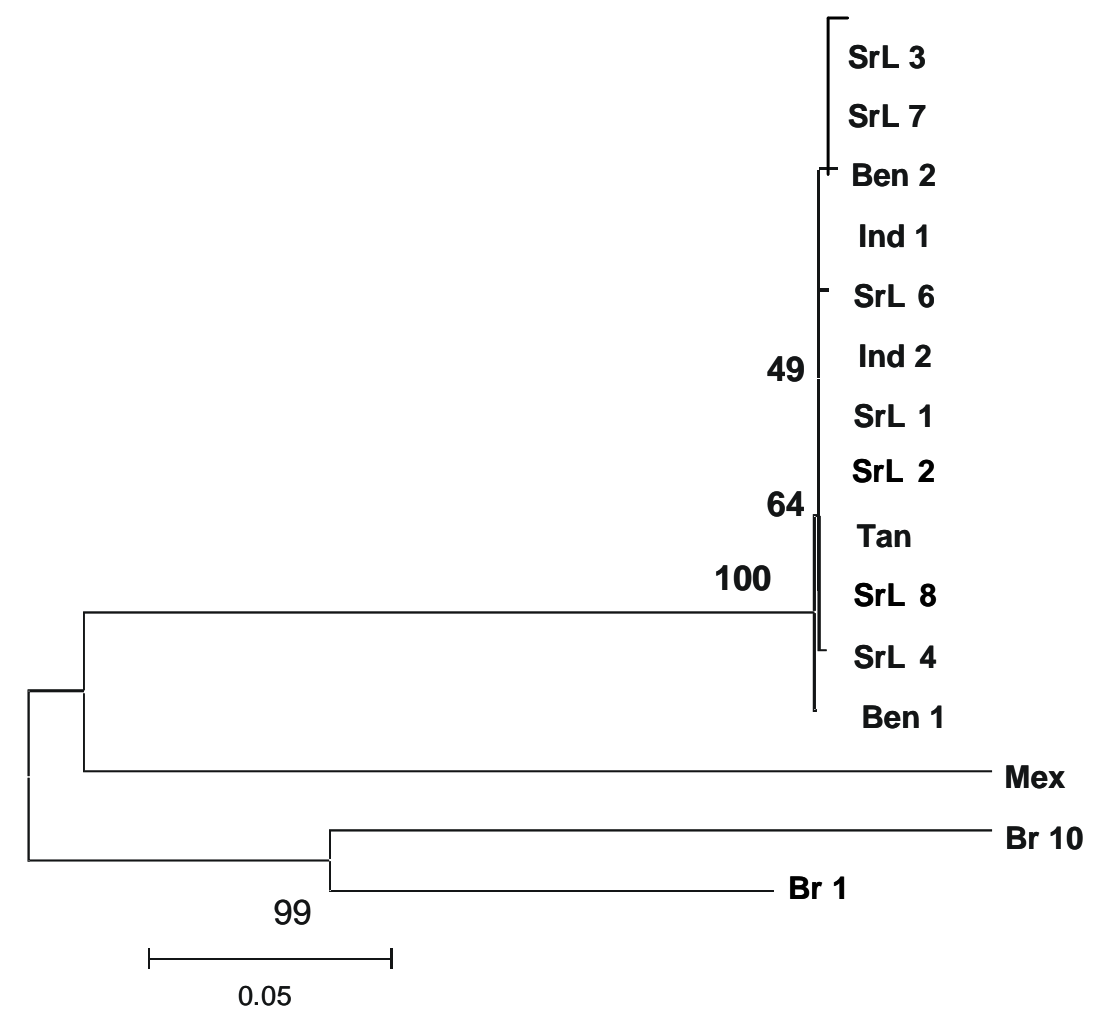

Figura 4 - Filogenia de populações de A. guerreronis baseada em seqüências da região COI do mtDNA, construída através de inferências Bayesianas. Os valores próximos aos nodos representam as probabilidades posteriores de suporte. Códigos representam as localidades de coleta das amostras especificadas na Tabela 1

Na filogenia obtida considerando-se as seqüências 16S, observou-se que as populações brasileiras de Aracaju (Br3) e de Maceió (Br8), Brasil estão muito próximas, em um clado bastante afastado de todos os demais. A proximidade destas populações e, ao mesmo tempo, sua separação da maioria das outras populações da América também foi verificada nas análises morfométricas.

Nas filogenias obtidas a partir de seqüências das regiões ITS e 16S, assim como nas análises morfométricas, nem sempre se observa uma relação direta entre a proximidade das populações brasileiras agrupadas e a proximidade geográfica dos locais 
de coleta das amostras. Na filogenia utilizando o fragmento 16S, esta relação foi observada entre poucas amostras, como por exemplo entre as amostras brasileiras de Aracaju (Br3) e de Maceió (Br8) ou de Ilhéus (Br10) e São Felix (Br9). A maioria dos clados agrupou populações provenientes de locais distantes, enquanto que amostras de locais de coleta bastante próximos foram posicionadas em clados distintos. Esta mesma tendência foi observada na filogenia ITS e nos resultados das análises morfométricas, indicando que nos clados ou ramos terminais, especialmente aqueles contendo populações do Brasil, não se observa uma relação entre proximidade geográfica e filogenética ou morfológica.

Observou-se uma maior variação na região ITS que na região 16S nas amostras de A. guerreronis analisadas. A taxa de evolução do DNA nuclear em relação ao mitocondrial é bastante variável entre espécies, mesmo que pertencentes ao mesmo gênero. Em ácaros de um mesmo gênero da família Tetranychidae, tem sido constatada uma grande variação nas taxas de evolução de regiões do genoma nuclear e mitocondrial. Navajas et al. (1998a) constataram que, em populações de T. urticae amostradas de uma ampla área de sua distribuição geográfica, havia cerca de 5\% de divergência de nucleotídeos na região CO-I do mtDNA, enquanto que nenhuma variação ocorria na região ITS 2. Os autores compararam também as taxas de evolução dos dois marcadores em um grupo de espécies do mesmo gênero e estes resultados não foram obtidos, observando-se que em outras espécies de Tetranychus a região ITS2 também variava. Os resultados mostraram que na verdade a região ITS evoluia 2,5 vezes mais rapidamente que a região CO-I em outras espécies de Tetranychus. Os autores sugeriram que a homogeneização das seqüências ITS2 em T. urticae era devido ao seu alto potencial de colonização e, consequentemente, a um fluxo gênico relativamente alto entre populações desta espécie a nível mundial. Para que se possa entender melhor as taxas de evolução destes marcadores em ácaros fitófagos, seria importante conhecer a taxa de evolução da região ITS do DNA nuclear em outras espécies de ácaros, inclusive de eriofiídeos, que apresentem diferentes potenciais de colonização e diferentes graus de polifagia. 
Parte da variabilidade da região ITS foi observada entre diferentes clones de uma mesma população, de modo que algumas vezes estes foram posicionados em distintos clados terminais. Levanta-se, então uma outra questão. Como estaria funcionando o mecanismo de "reparo evolutivo" em A. guerreronis?

Apesar de A. guerreronis apresentar uma variabilidade genética extremamente baixa na África e na Ásia, a espécie tem mostrado uma grande capacidade de se disseminar, estabelecer e atingir populações elevadas nestes continentes. Normalmente, uma alta variabilidade genética é associada ao alto potencial de adaptação das espécies a novos ambientes, entretanto isto nem sempre á verdadeiro, como discutido por Roderick \& Navajas (2003) e como foi observado para esta espécie de eriofiídeo.

Uma possível explicação para as filogenias obtidas a partir das seqüências de DNA nuclear e mitocondrial de A. guerreronis analisadas pode estar relacionada às trajetórias de colonização deste eriofiídeo. Os resultados obtidos são parcialmente consistentes com o histórico de disseminação e invasões deste ácaro-praga (construído a partir da literatura disponível), com a hipótese de que o coqueiro não seja o hospedeiro original do ácaro e com os meios de dispersão considerados possíveis dentro e entre continentes para este ácaro praga, conforme discutido a seguir.

\section{Histórico de invasões do ácaro do coqueiro}

Os relatos iniciais de danos causados por A. guerreronis foram quase concomitantes na América e na África. Na Colômbia, os primeiros sintomas foram observados desde 1948 (Bain ${ }^{7}$ citado por Zuluaga \& Sánchez (1971)); no Brasil, desde 1953 (Arruda, comunicação pessoal ${ }^{8}$ ) e no México, desde 1960 (Ortega et al., 1965). Simultaneamente, ou em um curto período de tempo após a descrição da espécie a partir de espécimes do Estado de Guerrero, México, sua presença foi relatada em vários outros países na América e na África (Moore \& Howard, 1996). Este eriofiídeo foi encontrado

\footnotetext{
${ }^{7}$ BAIN, T. M. Informe de la visita practicada a algunas zonas cultivadas de cocotero en la Republica de Colombia. Bogotá: División de Agricultura y Ganadería, Ministerio de Agricultura., 1948. $18 \mathrm{p}$.

${ }^{8}$ ARRUDA, G. P., IPA, Recife, Pernambuco, Brasil. Comunicação pessoal publicada em "Suplemento Agrícola do Estado de São Paulo", Jun 1967.
} 
no Golfo das Ilhas Guiné, em São Tomé e Príncipe, em 1966 (Cabral \& Carmona, 1969). Na África continental, A. guerreronis foi relatada pela primeira vez em Benin, em 1967, e em menos de dois anos foi constatado em todas as áreas de produção (Mariau, 1969, 1977). Apesar dos relatos sincronizados do ácaro nos dois continentes, a análise de amostras destes continentes, para as seqüências ITS e 16S, sugeriram que o ácaro se originou na América, onde apresenta uma diversidade de nucleotídeos mais alta e, provavelmente, da América do Sul, onde a diversidade parece ser maior (Tabela 2). A partir daí, deve ter invadido a África.

O primeiro relato da presença de A. guerreronis na Ásia foi do Distrito de Ernakulam, área central de Kerala, India (Sathiamma et al., 1998). Em 1999, os resultados de levantamentos mostraram que a praga encontrava-se estabelecida em todo o estado de Kerala, de Tamil Nadu e em áreas de Karnataka. A incidência do ácaro também havia sido relatada em três ilhas de Lakshadweep - Minicoy, Kalpeni and Kavaratti (Haq, 1999). Em Sri Lanka, A. guerreronis foi primeiramente detectada no final de 1997. O ácaro primeiramente surgiu na Península de Kalpitiya, Distrito de Puttalan, e então se dispersou a outras áreas de Kalpitiya, Wanathavillu, Puttalum, Madurankuliya e Rajakadaluwa, assim como a algumas áreas isoladas em Chilaw e Kuliyapitya (Distrito de Kurunegala) (Fernando et al., 2000).

Considerando a hipótese de uma origem americana para A. guerreronis, não está claro porque nenhum dos haplótipos americanos detectados não esteja presente na África ou na Ásia. Entretanto, a variação genética do ácaro na América é alta e, certamente, a diversidade da espécie foi apenas parcialmente amostrada. Esta interpretação é consistente com a alta homogeneidade das seqüências nucleares e mitocondriais e com a monofilia dos clados contendo as populações originárias da Ásia e África, que sugere que a colonização do continente africano, onde o ácaro foi relatado antes que na Ásia, se deu a partir de um número reduzido de indivíduos e que, provavelmente, ocorreu em um único evento de colonização.

A colonização de A. guerreronis na Ásia pode ter tido sua origem a partir de: 1) indivíduos de alguma população da América, não amostrada neste estudo, mas que provavelmente também teria sido a fonte de introdução da praga na África ou 2) a partir 
de indivíduos de populações africanas. Ambas hipóteses seriam coerentes com a proximidade das seqüências ITS e 16S, observada neste estudo, e com a similaridade morfológica, constatada através de análises morfométricas (Capítulos 7 e 8) entre as populações africanas e asiáticas.

Poderia também ser considerada a hipótese de que A. guerreronis já estivesse presente na Ásia, associada a alguma palmeira nativa, ou mesmo ao próprio coqueiro, em baixos níveis populacionais, sem causar danos e sem ser notada. Mudanças climáticas ou no sistema de cultivo poderiam então ter levado a espécie a atingir o status de praga. Entretanto, diversos levantamentos de ácaros eriofí́deos associados ao coqueiro, inclusive a frutos de coco, foram realizados na Região Indo-Pacífica, por lá ocorrerem outros ácaros eriofiídeos que causam danos a frutos em algumas áreas e devido à suspeita de que este grupo de fitófagos pudesse agir como vetor do agente causador da doença "cadang-cadang” (Briones \& Sill, 1963; Hall et al., 1980; Kang, 1981; Mohanasundaram, 1984). Naqueles levantamentos, a presença de A. guerreronis nunca foi relatada. Os resultados das análises das seqüências ITS e 16S das amostras da India e Sri Lanka também não corroboram a hipótese de que A. guerreronis já estava presente na Ásia. Não foi encontrada praticamente nenhuma variabilidade genética entre as amostras da India e Sri Lanka, tendo sido encontrado um único haplótipo. Esta homogeneidade genética indica que a espécie está presente na região há pouco tempo.

Neste trabalho foram amostradas apenas três localidades do continente africano, duas de Benin e uma da Tanzânia. Considera-se que esta limitação no número de amostras daquele continente tenha sido parcialmente compensada não apenas pelo distanciamento das localidades amostradas, mas, principalmente, pelo total isolamento geográfico das respectivas populações; a região central da África, entre as áreas litorâneas do oeste africano, onde está Benin, e as áreas do leste africano, onde está Tanzânia, o ácaro praga não tem sido relatado. Além do mais, o hospedeiro principal, o coqueiro, é escasso ou mesmo ausente em grande parte desta região. Este isolamento geográfico favoreceria um distanciamento genético entre as populações, o que seria detectado através das análises realizadas. De qualquer modo, será importante, em 
trabalhos que venham a complementar este estudo inicial, que seja coletado um maior número de amostras nas áreas litorâneas do Leste e Oeste da África.

\section{Hospedeiro Original de A. guerreronis}

A hipótese de uma origem americana para o ácaro do coqueiro seria contraditória à hipótese comumente aceita sobre a origem da praga ligada à principal planta hospedeira, entretanto, apoiaria a hipótese levantada por alguns autores de que este eriofiídeo teria se tornado uma praga devido à recente adoção do coqueiro como novo hospedeiro devido a alterações genéticas na espécie ou devido à expansão da cultura nas áreas onde já estava presente (Moore \& Howard, 1996; Moraes \& Zacarias, 2002). Desta forma, a origem de A. guerreronis corresponderia à região de origem da palmeira que seria sua hospedeira original desconhecida. Esta linha de raciocínio indica uma origem americana ou africana para o ácaro do coqueiro, continentes onde o ácaro estaria associado a uma palmeira nativa.

As principais indicações de que o coqueiro não é o hospedeiro original de $A$. guerreronis são: 1) A presença do ácaro não havia sido relatada no sudeste asiático até poucos anos atrás, quando foi relatado na India \& Sri Lanka e, até o momento, sua presença não foi registrada no extremo sudeste asiático e nas ilhas do Pacífico, região atualmente aceita como sendo de origem do coqueiro. 2) Os severos danos causados ao coqueiro por A. guerreronis, os quais chegam a prejudicar o desenvolvimento e o potencial reprodutivo do hospedeiro. 3) Adaptação de A. guerreronis a novos hospedeiros.

Várias hipóteses sobre a origem do coqueiro têm sido formuladas, mas há fortes evidências, suportadas por estudos moleculares, da origem Indo-Pacífica desta palmeira (Lebrun et al., 1998ab; Persley, 1992). O coqueiro está presente nas ilhas do Pacífico por milhões de anos e a menos de 500 anos atrás no oeste da África e na América (Purseglove, 1975 e Harries, 1978 citado por Persley, 1992).

Há indicações de que alguns eriofiídeos que infestam um determinado hospedeiro em seus locais de ocorrência natural, ocorrendo em baixos níveis populacionais, podem se reproduzir em hospedeiros exóticos (introduzidos) e formar 
populações numerosas sobre os mesmos, especialmente em condições de cultivo (Oldfield, 1996).

Infestações de A. guerreronis em coqueiros causam danos severos ou queda prematura dos frutos, que representam os órgãos reprodutivos da espécie, ou morte de plantas jovens (Moore, 1996; Aquino \& Arruda, 1967). Normalmente os ácaros eriofiídeos apresentam uma estreita relação com seu hospedeiro, não os levando à morte e, muitas vezes, até prolongando o período juvenil dos tecidos em que se alimentam. Infestações de eriofiídeos que danificam seriamente o hospedeiro podem indicar uma associação recente ácaro-hospedeiro. Um possível exemplo disto é o ácaro do bronzeado do tomateiro, Aculops lycopersici (Massee), que apresenta como hospedeiras diversas solanáceas à maioria das quais não causa danos e sobre as quais não atinge elevados níveis populacionais. Entretanto, quando infesta o tomateiro, pode levar plantas à morte. Considera-se que o hospedeiro original do ácaro da necrose do tomateiro possa ser alguma outra solanácea, e que a associação com o tomateiro seja recente, por isto os danos ocasionados seriam tão sérios (Oldfield, 1996).

Além do coqueiro, a ocorrência de A. guerreronis tem sido relatada em duas outras palmeiras na América (Flechtmann,1989; Ansaloni \& Perring, 2002). Em ambos casos, A. guerreronis foi encontrada em viveiros. Não se sabe, até o momento, se este eriofí́deo encontra-se associado a estas palmeiras em suas áreas de ocorrência natural no Brasil, apesar de alguns esforços terem sido direcionados neste sentido. Em levantamentos de ácaros eriofí́deos associados a palmeiras nativas e exóticas em alguns estados brasileiros e mexicanos, ainda não foram encontradas palmeiras hospedeiras de A. guerreronis em suas áreas de ocorrência natural (Capítulo 3). Recentemente, após os primeiros relatos de A. guerreronis na Ásia, Ramaraju \& Rabindra (2002) relataram altas infestações do ácaro em frutos de "palmyra”, Borassus flabellifer L., uma palmeira nativa da região, em Tamil Nadu, India. Frutos desta palmeira infestados por A. guerreronis também foram encontrados em Kalpityia, Sri Lanka (Moraes \& Fernando ${ }^{9}$ ).

\footnotetext{
${ }^{9}$ MORAES, G.J. Escola Superior de Agricultura Luiz de Queiroz (ESALQ), Universidade de São Paulo)
} \& FERNANDO, L.C.P (Coconut Research Institute, Lunuwila, Sri Lanka) (Em elaboração). 
Estas foram as primeiras constatações de A. guerreronis em palmeiras distintas de $C$. nucifera, em seus locais de ocorrência natural.

A análise das seqüências ITS e 16S da amostra de $A$. guerreronis de $S$. romanzoffiana, em San Diego (EUA1) mostrou que esta população é bastante próxima a quatro ou cinco outras populações da América coletadas de C. nucifera: Quissamã (Br4); Havana (Cub) (apenas em 16S); Fort Lauderdale (EUA2); Zulia (Ven); e Guerrero (Mex). Isto é, a todas as populações não brasileiras da América, e a uma população do Brasil (Br4). As seqüências ITS mostraram que esta última era a população mais próxima à do clone 1 de $S$. romanzoffiana, San Diego (EUA1 c1). Estes resultados sugeriram que a população que infesta $S$. romanzoffiana não representa um biótipo distinto, apesar de estar associada a um outro hospedeiro (não a C. nucifera como todas as outras populações). Isto pode indicar que esta associação seja recente. Este mesmo tipo de adaptação também pode ter ocorrido entre $A$. guerreronis e o coqueiro em tempos passados.

O relato das infestações de A. guerreronis em S. romanzoffiana na Califórnia, onde tem causado danos sérios em viveiros, é bastante recente (Perring \& Ansaloni, 2002). Não se dispõe de informação se a colonização desta palmeira ornamental teve sua origem a partir de indivíduos que infestavam C. nucifera nos EUA ou se foi introduzida naquele país através da comercialização de material de propagação vegetativa de $S$. romanzoffiana, procedente de outros países. Esta segunda hipótese pode ser levantada apoiada na proximidade mostrada nas análises ITS entre as populações de San Diego e Quissamã. Esta última no sudeste do Brasil, onde a palmeira ocorre em condições naturais. Os ácaros eriofiídeos são, de um modo geral, de difícil detecção, por suas reduzidas dimensões e localização em locais protegidos no hospedeiro, podendo passar despercebidos mesmo a uma inspeção detalhada. Devido ao aparente potencial de $A$. guerreronis de adaptação a novos hospedeiros e a não se conhecer o espectro de hospedeiros deste ácaro, ressalta-se a importância da adoção de medidas quarentenárias em relação ao transporte de material de propagação e frutos de palmeiras, de um modo geral, para evitar a disseminação deste ácaro invasor para novas áreas. 
Embora ainda não se conheça o hospedeiro original de A. guerreronis, as indicações de que o coqueiro não o seja e de que o ácaro apresenta potencial de adaptação a novos hospedeiros são consistentes com os resultados das análises das seqüências ITS e 16S, que mostraram baixíssima variabilidade do ácaro na Ásia, indicando não ser este originário daquela região, relativamente próxima à provável área de origem deste hospedeiro (Lebrun et al., 1998ab; Persley, 1992).

Os dados moleculares obtidos neste trabalho também são congruentes com a hipótese da presença de A. guerreronis na América, em outra palmeira hospedeira, antes da introdução ou disseminação do coqueiro no continente, a qual tem sido datada de cerca de 500 anos atrás (Purseglove, 1975 e Harries, 1978 citados por Persley, 1992). Observou-se uma diversidade relativamente alta de seqüências mitocondriais para as amostras americanas (média de 1,90\% para o Brasil). Tem sido estimado que a taxa de evolução dos genes mitocondriais seja de 1-2\% por milhões de anos (Brown et al., 1979). A diversidade observada nas seqüências mitocondriais nas Américas sugere de forma contundente a presença do ácaro no continente antes do evento da introdução ou disseminação do coqueiro no continente.

\section{Dispersão do Ácaro do coqueiro}

A rápida disseminação e estabelecimento do ácaro do coqueiro é possível devido ao seu grande potencial reprodução e reduzido ciclo de desenvolvimento (Haq et al., 2002). A colonização de um fruto jovem por uma única fêmea pode levar, rapidamente, à formação de grandes colônias, que subseqüente geram indivíduos que migram para novos frutos e plantas vizinhas (Moore \& Alexander, 1987). Estudos de campo na Índia mostraram a periodicidade diurna dos ácaros na superfície dos frutos. Esta tendência provavelmente inicia quando as populações aumentam nos frutos. Tanto adultos quanto imaturos foram encontrados ao redor do perianto (Haq et al., 2002). Moore et al. (1989) também observaram um grande número de ácaros na superfície dos frutos quando as populações sob as brácteas são muito altas. Ácaros caminhando na superfície externa dos frutos foram observados nas horas mais frescas da noite (Moore \& Alexander, 1987). Esta atividade pode auxiliar a disseminação dos ácaros por diferentes meios. 
A disseminação de A. guerreronis nas Américas e de lá para outros continentes parece uma possibilidade realista. Embora informação detalhada sobre a disseminação deste ácaro na maioria das áreas invadidas seja escassa, algumas hipóteses sobre seus meios de dispersão, através de rotas naturais ou atividade humana tem sido levantadas e suportadas por características comportamentais dos ácaros.

Aceria guerreronis parece apresentar uma migração dentro dos continentes ou de ilhas para continentes e vice-versa (Haq. et al., 2002), como indicado pela sua rápida disseminação na África e, recentemente, na Ásia, invadindo áreas distantes.

Correntes de vento têm sido apontadas como agentes de disseminação do ácaro (Griffith, 1984; Moore \& Howard, 1996; Haq et al., 2002). A dispersão aérea de fêmeas inseminadas permite a colonização de novas plantas. Por seu porte e arquitetura, o coqueiro representa um alvo para dispersão aérea e as probabilidade de que os ácaros possam encontrar um fruto é grande quando estes são carregados para os rácimos ou para as folhas mais verticais na coroa, de onde, posteriormente podem se deslocar para as inflorescências e para os frutos (Moore \& Howard, 1996). Também é possível que alguma dispersão ocorra através de forese, tanto por animais diretamente atraídos para as inflorescências (insetos polinizadores como abelhas) ou sobre aqueles atraídos por tais animais (como insetos predadores e pássaros) (Moore \& Howard, 1996).

A dispersão de A. guerreronis através da atividade humana pode ocorrer pelo transporte de frutos ou de plantas. Estudos conduzidos em Sri Lanka mostraram que ácaros vivos estão presentes em frutos maduros colhidos (12-13 meses de maturação) por mais de três semanas (Fernando et al., 2002). Um fruto jovem infestado pode apresentar até 140 ácaros por $\mathrm{cm}^{2}$ (Ramaraju et al., 2002). É possível que alguns indivíduos de A. guerreronis sobrevivam durante o transporte dos frutos protegidos pelas brácteas e, desta forma, colonizem novas áreas. Frutos de coco eram disseminados e intercambiados na antiguidade, através de correntes oceânicas ou em longas viagens. Atualmente são ainda transportados através do comércio internacional, turismo e intercâmbio de germoplasma. Há evidências de que o coqueiro tenha se disseminado amplamente através da flutuação de frutos em correntes oceânicas, germinando após serem lavados pela chuva em novas localidades. Foi também carregado pelo homem 
como fonte de alimento e bebida em longas viagens (Persley, 1992). Frutos são comumente usados como material de propagação vegetativa do coqueiro e o intercâmbio deste material, como germoplasma, em projetos de melhoramento genético ou comércio de variedades pode levar à disseminação do ácaro do coqueiro. Baudoin et al. (1998) relataram o movimento de germoplasma de coco no mundo, que se deu principalmente através de sua coleta em países estrangeiros ou intercâmbio de germoplasma entre centros de pesquisa.

Este estudo traça uma possível trajetória de disseminação e invasão do ácaro do coqueiro nos três continentes onde sua presença tem sido relatada. O cenário evolucionário deste ácaro-praga ainda não está completamente reconstruído, mas os resultados obtidos trazem à luz alguns pontos fundamentais sobre a estrutura genética do ácaro, que devem ser determinantes no planejamento de um programa de controle biológico.

Espera-se que inimigos naturais efetivos para o controle de uma praga sejam encontrados em sua área de origem, onde a praga e seus agentes de controle tiveram contato por um período de tempo mais longo e onde o equilíbrio entre os mesmos possa ter evoluído (Van Driesche \& Bellows, 1996). Um exemplo de sucesso na implementação de um programa de controle biológico clássico de uma espécie de ácaro fitófago invasor, através da introdução de inimigos naturais provenientes de sua área de origem, é o do controle de Mononychellus tanajoa Bondar na África, através da introdução ácaros fitoseídeos da América do Sul, região de origem deste ácaro (Bellotti et al., 1999).

A indicação dos resultados deste trabalho de que A. guerreronis tenha origem americana, sobre uma espécie de palmeira diferente do coqueiro, são importantes pontos a se considerar em um programa de controle biológico clássico. Estes pontos sugerem que na prospecção de agentes de controle de A. guerreronis, devem ser priorizadas áreas na América, especialmente na América do Sul, onde foi encontrada uma grande diversidade genética da praga, não apenas sobre o coqueiro, mas também em outras palmeiras em que A. guerreronis possa ser encontrada. Esta prospecção poderia adotar as seguintes estratégias: 1) a busca do hospedeiro original de A. guerreronis, sobre o 
qual seus inimigos naturais poderiam ser encontrados; 2) a busca em coqueiros, em regiões que apresentem condições favoráveis à ocorrência do ácaro, mas onde danos severos não venham sendo relatados, onde estes eriofiídeos estejam provavelmente sendo controlados por seus inimigos naturais.

Aceria guerreronis continua representando uma ameaça para os países da Ásia e do Pacífico, onde sua presença ainda não foi relatada. Os resultados deste trabalho possibilitaram a proposição de hipóteses sobre como o ácaro foi recentemente introduzido na Ásia ou como colonizou S. romanzoffina na Califórnia. Estudos mais aprofundados deverão, no futuro, esclarecer melhor as possibilidades levantadas. No momento, considerando as indicações de que o coqueiro não seja o hospedeiro original de A. guerreronis, que este hospedeiro ainda não é conhecido e que este eriofiídeo apresenta potencial de adaptação a novas palmeiras, considera-se que o transporte ou comercialização de material de propagação vegetativa de palmeiras representa risco de disseminação da praga e que procedimentos quarentenários devem ser adotados em relação a estes materiais.

\subsection{Conclusões}

* Há uma alta diversidade genética entre as populações americanas de A. guerreronis, especialmente entre as brasileiras.

* As filogenias obtidas para as seqüências ITS, 16S e CO-I apresentaram topologias similares

* As populações de A. guerreronis compõem dois clados principais: um americano e um afro-asiático. Os clados obtidos refletem uma estrutura geográfica relacionada ao restrito fluxo gênico e ao isolamento entre as populações que os compuseram. 